\title{
CANADIAN
}

\section{TURF RECOLLETIONS}

ANA

\section{ONHER SKETCHES}

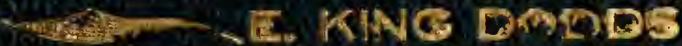




\section{$G 83 \div \frac{60}{0}$}

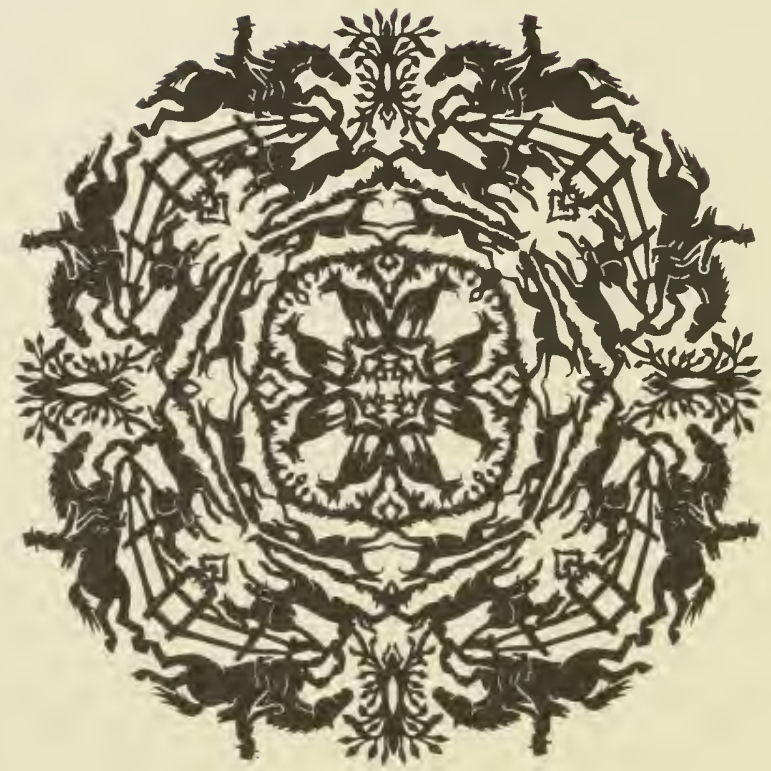

JOHN A.SEAVERNS 
Wabster Family Library of Veterinary Medicine Cummings School of Veterinary Modicine at Tufts University 200 Westboro Road

North Grafton, MA 01536 





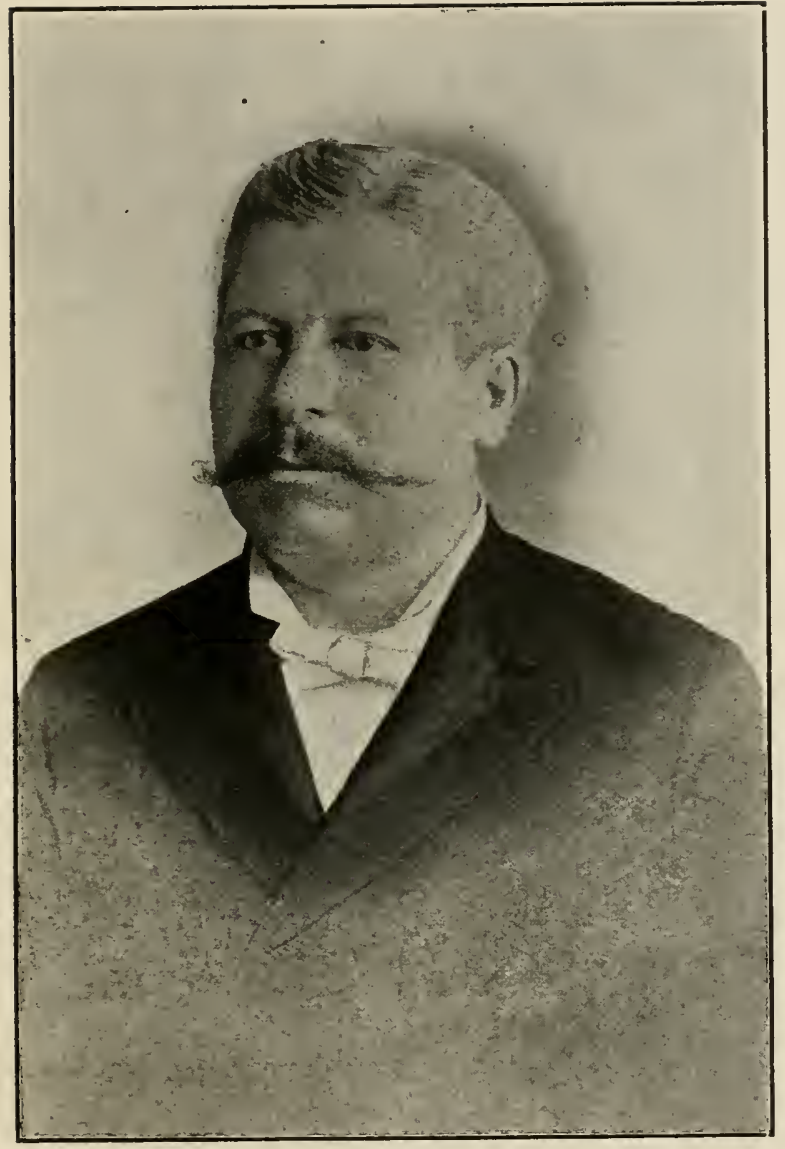

THE AUTHOR. 



\title{
CANADIAN
}

\section{TURF RECOLLECTIONS} AND

\section{OTHER SKETCHES}

\author{
BY
}

\section{E. KING DODDS}

Author of "Notes by a Guerilla," \&c.

Toronto, Ontario, Canada.

1909 
Entered according to the Act of Parliament of Canada in the year one thousand nine hundred and nine, by E. King Dodds, Toronto, in the office of the Minister of Agriculture at Ottawa. 


\section{CONTENTS.}

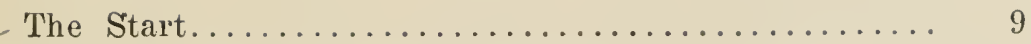

- Future of Racing in America................... 11

The Duty of Canadian Turf Managers............. 17

The Right Hon. Earl Grey, Governor-General of Canada. 23

Horse Breeding in Canada.................... 25

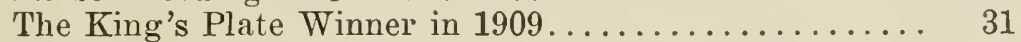

The Queen's Plate at Whitby in $1870 \ldots \ldots \ldots \ldots \ldots . . . . .34$

- Military Race Meeting at Lambton Mills in the Sixties.. 38

- A Gallant Old-Time Race at Toronto.............. 43

-A Memorable Race Meeting in Montreal in $1873 \ldots . . . .49$

At Splendid Meeting at Carlton Park in 1874......... 52

The Mistress of Cruickston Park................ 56

A Good Performer Thirty Years Ago.............. 62

-A Joke on Dr. Andrew Smith and David Alexander.... 64

-A Thoroughly Honest Trainer................. 66

- Ye Olden Times........................... 71

Terror's Great Race at Ottawa................. 74

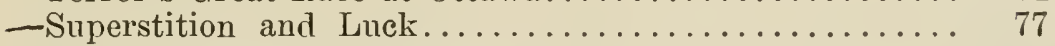

The Doctor's Practical Joke.................. 81

The Great Steeplechaser Milesian............... 85

A Notable Race at London..................... 89

The Lady Washington Race at Carlton Park.......... 91

A Story About the Late Charles Gates............... 94

The Raven Dropped by the Way............... 99

Past and Present Province-bred Horses Compared...... 102

A Few Old-Time Sportsmen................... 105

Three Mile Heats on the Don Race Course in 1846..... 112

Past and Present Racing..................... 115

Eleven Heat Running Race................... 120

A Merry Day Tip......................... 121

Nettie's Triumph at London................. 124

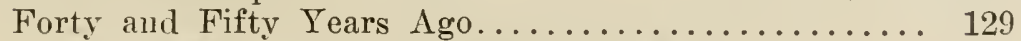

A Notable Mile Heats Race, Three in Five............ 133

-A Noted Owner and Breeder of Thoroughbreds......... 136

-The Late William Hendrie................... 138

A Welcome Addition....................... 144

-A Well Known and Popular Turfman.............. 146

Sir H. Montagu Allan, President Montreal Jockey Club. 148

Do You Carry a Rabbit's Foot?.................. 151

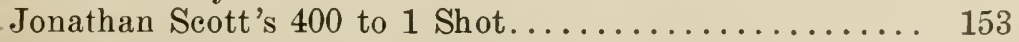

Jack the Barber Shaves His Backers............. 157

-The Preacher and Jack Vandal................. 160 
-The Late John Hendrie....................... 163

- A True Sportsman Every Inch of Him.............. 165

-A Representative Railway Contractor and Turfman.... 170 -Angus Sinclair, a Former Noted Breeder of Trotters.... 173

How Six Hooks Reflected Seven................. 176

A Day of Sensational Luek.................. 178

Canada's Veteran Trainer, Charles Boyle............ 183

- Canadian Owners and Their Colors.............. 186

- A Canadian Bookmaker's Experience at Saratoga...... 193 Ho! The Gypsies......................... 194

He Was One of the Right Sort............... 198

Riley Grannan Took a Hand In............... 200

How a Lobster Stopped a Grand Trunk Express........ 204 The Home of the Ontario Jockey Club............ 207

The IIontreal Jockey Club.................. 209

-The Windsor Racing Association............... 214

-The Hamilton Jockey Club................. 216

A Canadian "Guerilla" Yarn.................. 218

An Old-Time Forty-Mile Trot............... 220

- A Trotting Match in Montreal in the Seventies....... 224

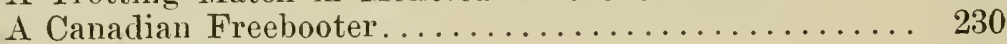

-A Notable Race on the Ice................. 235

-Four-Mile Trotting Spin at Owen Sound.......... 238

Mr. Riley's Floating Track................. 245

The Way They Found It................ 247

My Experience With a Puller............... 249

-An Eastern Equine Which Failed to Score.......... 251

-Toronto, the Great Iforse Market............. 25.5

The Unexpected Often Happens................ 257

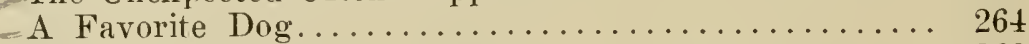

Casting by Moonlight for Bass............... 268

The Glorious Northland-The Horne of the Lordly Moose 271

Deer Hunting in Haliburton................. 277

A Few Suggestions and Recollections............ 28.5

A True Fishing Story................... 288

Did the Birds Reason It Out?................. 290

After a Railway Bonus...................... 293

A Plowing Mratch That Did Not Come Off.......... 296

A Corner on Rats...................... 300

Thorneliffe Stock Farm.................. 303 


\section{THE START.}

"There are many good people who eall horse racing a sinful amusement and say hard things about those who patronize it. There are also a large number of equally good people who see no harm in the sport and heartily encourage it. I am not ashamed to own that I was one of the big crowd of sinners who attended the races on the town moor this afternoon. I am also not ashamed to own that $I$ enthused over the splendid struggle between the three gallant thoroughbreds which fought out the finish in the Wilton Plate, and it was not surprising that deafening cheers rewarded such an exhibition of gameness. I know many good men also who will back their favorite horse, yet are in no way deserving of being stigmatized as gamblers for so indulging. Racing honestly conducted is a noble sport and many of the most celebrated names in our national history have been pillars of the turf. It is the favorite sport of our people and is likely long to remain so."

The above words it was my privilege, when a mere boy, to hear fall from the lips of one who was then a central figure in the political history of Europe; a statesman whose bold and fearless foreign policy had made him the idol of his countrymen. The speaker was Lord Palmerston, Premier of Great Britain, and the occasion, a county dinner at a race meeting in Wiltshire.

No man in English public life ever understood his countrymen better than Lord Palmerston. Though an aristocrat by birth, he was eminently a man of the people. He was equally at home in the homes of the poor and in the palaces of the great. In a word. he was one of those outspoken, fearless public men whose actions were ever guided more by principle than by policy. 
What he said regarding the popularity of racing in England is also true of its status in this country, and I am proud of the fact that for forty years I published a newspaper devoted to Canadian turf interests, ever fighting for the right as I saw it. During those years much interesting sport was recorded and from my memory I have here served up some recollections of the most notable events.

Handicapped by total blindness which befell me five years ago and suffering for many months past from a painful illness, which for days at a time prevented concentration of thought, must plead my apology for many imperfections in these pages. 


\section{FUTURE OF RACING IN AMERICA.}

Black is the cloud which at the present time overshadows the future of the thoroughbred horse in America.

The question whether racing without the privilege of betting being allowed will prosper, is not one which I intend discussing in these pages. There can be no doubt, however, that the passage of an anti-betting law by the New York Legislature, which was due entirely to the personal efforts of Governor Hughes, has had a demoralizing effect upon the fortunes of the sport in the Empire State. It reduced the value of eastern racing properties by many millions of dollars and reduced by still more millions the value of thoroughbred horses in the United States. It also took out of the treasury of the Agricultural Societies of New York State about $\$ 250,000$ a year, which they received from a special tax imposed upon the racing clubs for their benefit and which was used by the Societies in increasing the value of their prize lists.

Whether the end sought to be accomplished will be secured and thus justify the radical measures employed is a problem which may only be solved by actual experience in the working of the law. So far there have been many legal fights in the courts and many contradictory decisions by judges. The result is a good deal of what may be tersely described as "whipping the devil around the post," and just what is legal and what is illegal wagering is something that even men learned in the law cannot agree upon. Hence a condition of affairs which is neither satisfactory to one side or the other.

In the past the horse has played a prominent part and occupied a high place in the affections of the people. Some of the most glorious struggles in the history of the 
American turf are those which marked the contests between representative horses of the north and south, and though the Civil War gave a mighty setback to the sport, the recovery after the close of the war was wonderfully rapid.

Breeding farms famous in equine history are now no longer the home of the thoroughbred, and the pastures over which once roamed the heroes and heroines of the turf are to-day grazing lands for herds of cattle. McGrathiana, Woodburn, Filmendorf, Fairview, Belle Meade, Rancocas, Dixiana, etc., etc., are now little more than memories of a glorious past. Stately homes and great estates over which the thoroughbred ruled king are to-day tenanted by an altogether different class of animals, and beef, pork, and mutton are more familiar subjects of conversation than the chances of Futurity candidates and other classic races of the American turf. Mighty is the change that has taken place and the reason is not difficult to determine. When sport is degraded by being conducted for the sole purpose of money making, evils and abuses creep in and public confidence is soon shaken. Men utterly destitute of sportsmanlike qualities went into the racing game solely because of the chances it offered to make big profits. Tracks were built all over the country, a liberal proportion of them by men of questionable reputation, in fact, many of these were under the absolute control of professional gamblers. The management of such places was directed solely to extracting the largest possible amount of money out of their patrons. Disreputable owners of horses were shielded instead of exposed, and altogether the condition of affairs became so deplorable that general public indignation was aroused and those in authority were not backward in introducing measures of reform. The Legislatures in many States passed anti-betting laws and the result has been the closing of nearly every track in the West. Racing properties representing a cost of millions of dollars and which, when operated, paid princely incomes to their owners, are now deserted and 


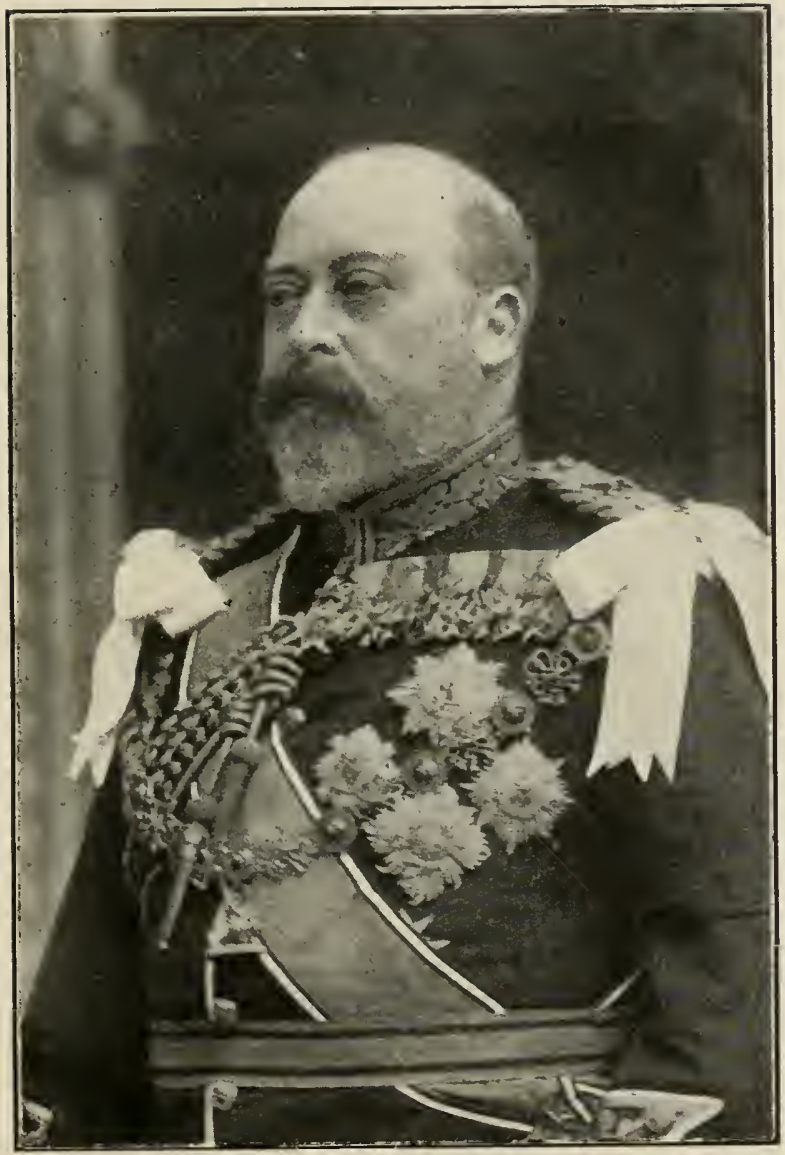

HIS MAJESTY KING EDWARD VII. 

costly grand stands and palatial club houses crumbling to decay are stern reminders of the reckless management which caused such ruin.

Racing, when honestly conducted, requires neither apology nor defence for its existence. It is the favorite sport of the people in Great Britain and France, and has the approval and patronage of the highest in those countries. The King of England is the representative turfman of the Empire, and some of the most important turf events, including the Derby, the greatest of all, have been won by horses the property of His Majesty. The President of France is also a staunch supporter of the turf and the Government of that country is lavish in its expenditure for promoting the interests of the thoroughbred. Here in Canada, the Ontario Jockey Club is our representative turf organization and now its meetings compare favorably with the best held in any land. Its founder, Mr. T. C. Patteson, was a man of wide racing experience and one of the best posted turfmen to be found in any country. He was also possessed of indomitable energy, and for many years acted as manager of the Club. After he retired from that position men of less knowledge, but of equal enthusiasm, took up the good work and the Club's present prosperity is substantial proof of their success. Past Presidents of the Club were Sir Casimir Gzowski (aide-de-camp to the Queen), Sir Frank Smith and Mr. Wm. Tendrie. All of these are now dead and their successor is Mr. Joseph E. Seagram, the most extensive breeder of thoroughbreds in Canada and owner of the greatest racing stable in this country. The Ontario Jockey Club enjoys the confidence of the public, and though mistakes have been made their patrons know that honorable men are in control and that their best efforts are ever directed to guard the interests of those who patronize the sport.

Its spring meeting, which always commences the latter part of May and at which the King's Plate, the Blue Ribbon of the Canadian turf, is the star racing fixture, attracts an attendance on the day it is run of about 
fifteen thousand people, and during the two weeks in which the racing is held an average daily attendance of from six thousand to eight thousand is the record. The engraving published elsewhere give a fair idea of the appearance of the lawn on "Plate" day.

Canadian turf interests have been greatly strengthened by the formation of the Montreal Jockey Club, whose famous Blue Bonnets track is to-day one of the best racing properties in America. Its President, Sir Montagu Allan, head of the great shipping firm of that name, is a figure of national interest, while the other officer's of the Club are amongst the most representative business men of the commercial metropolis. Their meetings, two of which are held each year, are well supported and the noble sport, thanks to their wise and liberal management, is receiving generous public patronage.

In the west, the Hamilton Jockey Club, the Windsor Racing Association and the Fort Frie Racing Association are all prosperous clubs which hold two meetings each year, at which liberal stakes are given. The Canadian Racing Association has been formed for the purpose of properly guarding and protecting the interests of the sport in this comntry, and if its laws are wisely administered much good will be the result. 


\section{THE DUTY OF CANADIAN TURF MANAGERS.}

"Eternal vigilance is the price of liberty," and it can be truthfully said that the eternal vigilance of those who manage our turf clubs is necessary for the proper protection of the public. It is a fact beyond dispute that the demoralization of turf affairs in the United States has sent into Canada a class of owners of an undesirable kind, many of them owning a few cheap animals and in the game solely for the purpose of making money whether by fair means or foul. When Canadian meetings were not invaded by foreigners to any noticeable extent, the same anount of watchfulness on the part of officials was not necessary, but at the present day it requires the keenest supervision to properly protect the race-going public. Whether or not the men who at the present time are acting as judges at the leading running meetings in this country, are quite able to successfully deal with the matter, is a question which I do not propose to argue, but that there is a tendency to deal too leniently with offending owners is apparent to all close observers. It may be that some officials are afraid of causing scandal if they hew too close to the line. Again, I am afraid that the personal interests of track owners are sometines allowed to influence the judgment of those who are expected to deal out strict justice without fear, favor or affection being allowed to influence their decisions. The ruinous results from allowing bookmakers to do business at tracks where they own horses competing in the races, has been illustrated at nearly every course on the other side and the injurious combination has had much to do with the present condition across the border.

I have no doubt it will be said by some officials that such a state of affairs does not exist on this side and that they have expressly taken action to prevent such a com- 
bination. I do not deny their statement, but I do declare that in many instances their orders have not been obeyed. Bogus transfers of horses have been made by bookmakers to friends and these in many instances have been done in such clumsy fashion that it was easy of detection if enquired into.

Again, there are certain owners so closely mixed up with bookmakers that grave suspicion attaches to the combination, and it is not going too far to say that their loorses are often run in the interests of those who lay the odds. Much of the trouble is directly traceable to the fact that a low class of Jew gamblers have, during the past few years, invaded the ring and may now be said to practically control it. A liberal percentage of them are absolutely devoid of principle and act on the belief that their mission in life is to get money; make it honestly if they can, but make it anyhow. It does not require a Conan Doyle to detect the chief manipulators in this line of business. Their greed invariably oversteps their prudence, and an experienced turfman, going the rounds of the ring during the progress of a race, can easily spot the conspirators who have a card up their sleeve. One of the most pressing duties which devolves upon the managers of our race meetings is to have at their command the services of a thoroughly competent person such as described above. The information such an official could present to the stewards on duty, immediately prior to each race, would be of great value and it would often defeat any rascally schemes entered into.

Avoid scandal, is the prompting of a timid mind; expose fraud whenever and wherever detected and spare not the guilty ones, is the only honorable and safe course to pursue. It is a duty which every patron of the turf has a right to demand from those in authority and if that duty is faithfully carried out, public confidence is secured and the efforts of unfriendly critics are largely checkmated.

We ought to be wise enough in Canada to steer clear of the rocks that wrecked so many millions of dollars' 
worth of racing property in the Republic. The turf enjoys legal rights here which should be thoroughly appreciated by those who control our racing associations. If they act wisely and judiciously the present satisfactory condition may not be altered, but any slackness on their part would bring about a speedy repeal of the privileges they now enjoy.

The patronage extended to the running turf just now in Canada is of the most liberal, and those who have money invested in such enterprises must be reaping a return far beyond what is derivable from the profits of any ordinary business. Under these circumstances the Clubs can afford to adopt every means necessary to properly safeguard the interests of their patrons and the Clubs which neglect to do their duty in this respect are unworthy of public patronage.

Those who argue that the stoppage of racing in the United States has been of great benefit to the Canadian turf, are simply superficial observer's whose opinions are of little value. Instead of benefitting us, I am of the opinion the reverse is the case. True, it has sent over a number of owners to race here who did not previously come north of the border line, but as a rule they have been of a class requiring a heap of watching to checkmate them. Their horses are in and outers according to stable orders and the public, or at least that portion of it who are foolish enough to speculate upon the performances of animals controlled by such a class of owners, are brightly illustrating the trite saying that "fools and their money are soon parted."

These foreigners come here on the hunt for Canadian coin, practically driven out of their own country through lack of employment for their horses. They welcome this as a veritable haven of refuge. They may be sports, they certainly are not sportsmen. They have no respect for our turf laws and consequently make no effort towards loyally supporting the rulings of those in authority. So long as they think they can escape detection and consequent personal disqualification they will take long 
chances, and every independent turf official in Canada to-day can bear testimony to the truth of my statement.

How best to remedy the evil which threatens to increase and thus add to existing perils, demands careful study and the most serious consideration. One thing is certain, protracted race meetings in the United States had nuuch to do in bringing about the ruin that has overtaken the sport in that country and we shall indeed deserve no better fate than overtook them unless we steer clear of the primary cause of destruction. 


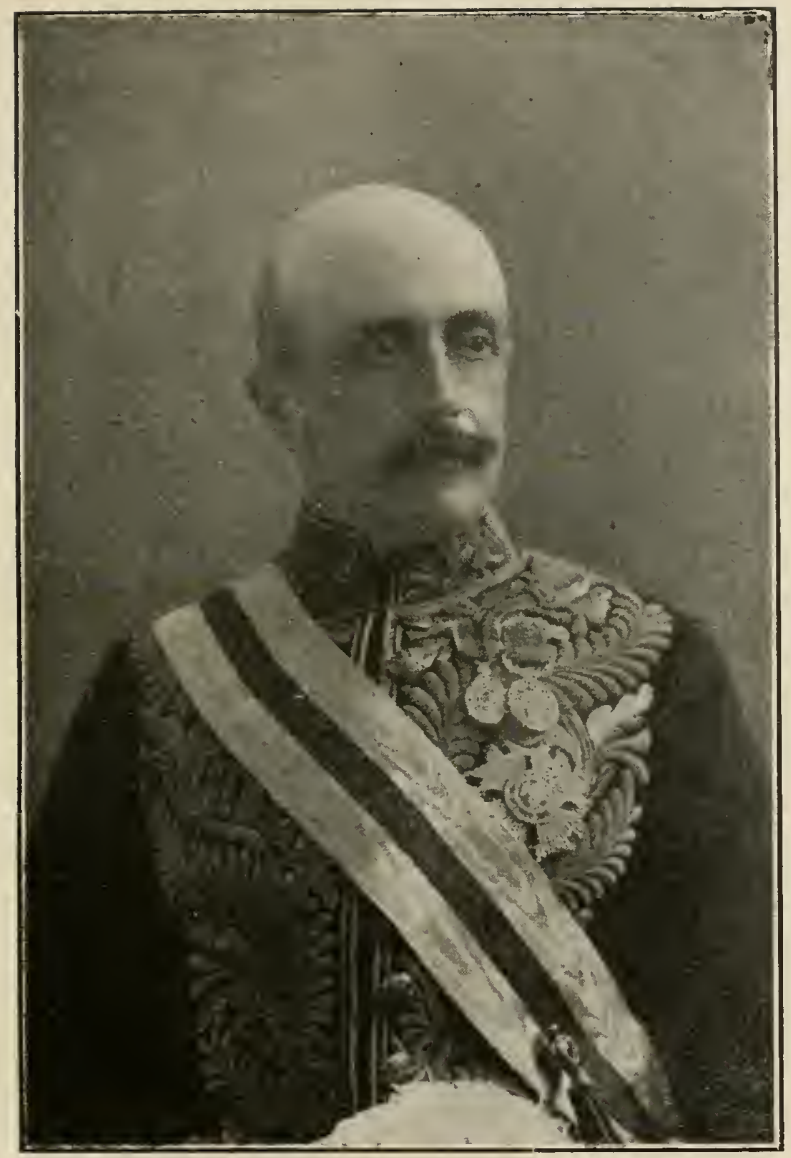

RIGHT HON. EARL GREY, GOVERNOR-GENERAL OF CANADA. 

THE RIGHT HON. EARL GREY, GOVERNORGENERAL OF CANADA.

"It was one of Dunlop's best, but I could not withstand the temptation to throw it aloft, thus illustrating my feelings at the sight I had just witnessed. I am an American citizen and am proud of it, but I am sorry to admit that no President of my country dare show such liberality of thought and such freedom of action as the representative of your King has shown by coming in state to honor the opening day of the Ontario Jockey Club meeting."

Such was the language used by a citizen of New York who was present at Woodbine Park on the opening day of the May meeting, 1909, and it was caused by the arrival in state of the Governor-General of Canada. Conspicuous amongst the thousands who cheered the vice-regal arrival were hundreds of Americans who made themselves particularly noticeable by their extraordinary exhibition of enthusiasm.

Many brilliant men have been numbered amongst our past Governor-Generals, but I doubt if any previous holder of the high office ever popularized himself to such an extent with all classes of our people. Earl Grey is eminently a man of action. Brimful of dash, energy and enthusiasm, he has used these qualities unsparingly in the discharge of his duties. Determined to obtain a knowledge of the great country over which he rules, he has journeyed from ocean to ocean and by personal investigation made himself familiar with the vast resources of the Dominion.

His speeches, delivered in the different provinces, prove how thorough a knowledge he possesses of the resources and future possibilities of the sections he visited, while on those occasions when he spoke in the 
United States, his speeches, by the force of their statesmanlike quality, commanded wide public attention.

Earl Grey is an absolutely fearless man. What his judgment approves he never hesitates to support. He believes that racing, properly managed, is a noble sport, and in the hands of the class of men who compose the Ontario Jockey Club he recognizes that the sport is firmly and honestly controlled. There can be no doubt that his attendance at the meetings of the Ontario Jockey Chub has not only greatly benefited that association, but has also popularized the sport all over Canada.

Descended from a long line of illustrious ancestors, conspicuons as soldiers and statesmen, he has proved himself a worthy son of noble sires, and when the day comes for the Governor-General to leave this comtry he will carry with him the respect, affection and admiration of all whose good opinion is worth having. 


\section{HORSE BREEDING IN CANADA.}

There is no industry in connection with Canadian agriculture that has seen more ups and downs than that of horse breeding. There used to be a big demand in this country for tramway horses, but when electricity displaced the quadruped all sorts of evil was prophesied as a result of the change. Thousands of undesirable horses filled Canadian barnyards. They were a common lot, monsrel bred and fit only for the rork they had been bred for. The commonest kind of stallions had been used, the chief consideration of the majority of owners being chearness of service. Fortunately a demand sprang up in Eugland for cheap horses for tramway purposes and Ontario was soon cleaned out of the commoners, thousands being shipped across the Atlantic. Once rid of the mongrels Canadian farmers were urged to breed a higher type of horse. There were lots of good mares in Ontario at least, and by dint of hard, persistent work of the press a change was inaugurated and the mongrelbred stallion was no longer the preferred sire. Next, the war in Soutl Africa provided the Canadian breeder with a profitable outlet for his stock, and as the Imperial officers were not unreasonably exacting in their demands, thousands of horses were purchased in Ontario at prices that paid a handsome profit to owners. The only regrettable feature in connection with this African demand was the large number of well-bred mares that were shipped out of the country but, tempted by the high prices procurable, farmers could not resist the temptation to sell, and a serious drain of our broodmare stock was the result.

When the demand for our horses for war purposes had ceased, Canadian breeders had confidence in the future and kept on breeding a superior type, and their confi- 
dence has been amply rewarded. Stylish, well-bred horses were never worth more money in the Canadian market than they are at the present time. I am not speaking of speed. That quality, when there is sufficienet of it, commands a fancy price, but there is a lottery about the game of breeding for speed alone that does not pay the farmer to engage in. Stylish matched pairs, well-bred saddle horses, high steppers, stout cobs and sound work horses command high prices all the year round. There is, therefore, no branch of farm industry which promises more successful results.

The present satisfactory condition of the horse trade in Ontario is due largely to the energy and skill of those engaged in it. For more than a quarter of a century the writer advocated government assistance towards the development of the industry. Although there were many ardent admirers of the horse in the local Parliament it was not possible to secure official action. It was only when the present Ontario Government came into power that a move was made. Commissioners were appointed who visited all parts of the province and made exhaustive enquiries into existing conditions. The statistics gathered by them have provided the Department of Agriculture with much valuable information and strong hopes are now entertained that this important question will be dealt with in that progressive spirit which characteizes the government of Sir James P. Whitney.

County Agricultural Societies should be assisted in offering liberal cash premiums for the best specimens of the different breed of horses. The prize lists should recognize every class and the premium money offered should be of sufficient value to tempt breeders to compete. The competition in each county should be confined to animals bred in that particular municipality so as to prevent the possibility of one or two extra rare specimens being permitted to sweep the board in other counties and thus discourage competition in those sections. The prize lists should recognize stallions, broodmares, yearlings, two-year-olds, three-year-olds and all ages. 
Such county shows, in addition to the direct encouragement so offered to breeders would supply to buyers a valuable directory, furnishing information respecting the sections of country in which they would be most likely to secure the class of horses they dealt in.

A short time since an official estimate placed a value of eighty millions of dollars on the horse stock of this province. Such a valuable interest surely deserves encouragement, and if the same were forthcoming to a reasonable extent this country would soon attract the attention of European dealers. Many foreign governments are lavish in their expenditure to secure improvement in the breeding of horses, and the result has been so satisfactory that in France in 1908 the demand from foreign buyers became so great that the government found it necessary to issue orders refusing to allow, for a specified time, the further exportation of certain breeds.

Our climate is a favorable one for the production of a good class of equines. Canadian-bred horses have held their own in the prize ring in competition against the best in America. At the great horse shows held in New York, Boston, Philadelphia, Chicago, St. Louis, etc., our representatives have won high honors and the demand from foreign buyers for this quality of stock has always been in excess of the supply. Even in England, where the breeding of the saddle and hunter horse has been brought to the highest perfection, the Hon. Adam Beck secured first honors with several animals bred in the counties of Elgin and Middlesex, and his victories were the more notable from the fact that the popular member of the Ontario Government was in the saddle and pitted against him were a number of the crack gentlemen riders of Europe.

The action of the breeding bureaus, established through the influence of the Ontario and Montreal Jockey Clubs, in sending thoroughbred stallions, free of cost, to many sections all over the Dominion, cannot fail to be productive of much good in improving the quality of horses for 
saddle purposes. It was the liberal use of the warm blood in years gone by that attracted foreign attention to the superiority of our saddle and carriage horses. Present efforts, therefore, in supplying thoroughbred sires to those districts where they are likely to receive the most liberal patronage will certainly result in much future improvement in the quality of the classes alluded to.

What we have accomplished in the past is substantial proof of our ability to hold our own against all comers, and if those in anthority will properly appreciate the vast importance of this horse-breeding interest Ontario would in a few years become a centre of attraction to European as well as American buyers. 


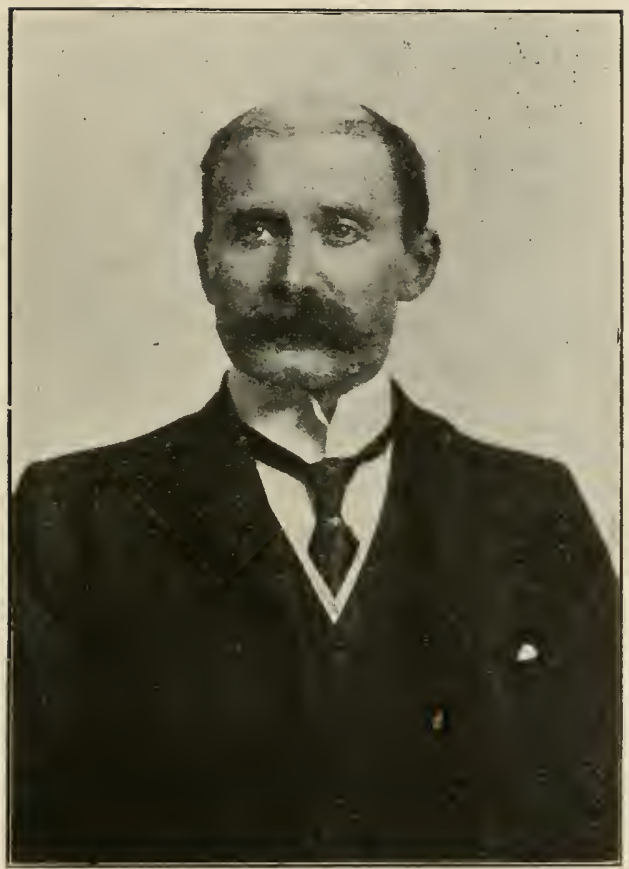

SIR H. MONTAGU ALLAN, PRESIDENT MONTREAL JOCKEY CLUB. 



\section{THE KING'S PLATE WINNER IN 1909.}

There is a little history in connection with Shimonese, the winner of the King's Plate in 1909, that may prove interesting to Canadian turfmen

Some years ago Mr. Joseph E. Seagram purchased at auction in New York the mare Spark, a full sister to Lamplighter, one of the crack race horses of his day. If my memory serves me right, and I was present at the sale, the Squire of Waterloo paid $\$ 1,500$ for her. A few minutes after she had been knocked down to his bid a prominent trainer approached Mr. Seagram and offered him $\$ 500$ on his bargain. The offer was declined. Spark was brought to the Waterloo farm and bright hopes were entertained that she would prove a star matron of the Waterloo stud. Her eareer, however, as a broodmare while there was a dismal failure and the writer was

- instructed by her owner a few years later to catalogue her for the annual auction sale.

Her first foal was club-footed and was destroyed. Her second foal was also deformed and shared the same fate. Her third was "no account," and she was reluctantly admitted to be a failure. At the sale, which took place at the Repository in Toronto, Spark was purchased by Dr. Andrew Smith for the sum of $\$ 120$, who in turn passed her on to Mr. Hendrie. That gentleman bred her to his own horse, imp. Derwentwater, and the produce was Lyddite, with whom, in 1902, he won the first King's Plate, being his second victory in the classic race of the Canadian turf (his first being scored with Butterscotch, with whom he won the Queen's Plate in 1899), although he had persistently struggled for success every year with horses of his own breeding. 
In 1905 Lyddite was bred to Martimas, winner of the Futurity, 1898, the champion two-year-old stake of the American turf. He also won the Flatbush a few days later, again defeating in decisive fashion the best youngsters in training. This race, however, was taken from him on the claim of a foul, although in the opinion of many experienced turfmen who closely watched the race, the Canadian representative was not to blame. His daughter, Shimonese, by her brilliant victory in the Plate, in which she liung up a new record for the race, although she won in a gallop at the finish, is a worthy daughter of a famous race horse.

Having yarned about her dam and grandam and sire, I may as well spin another about Lamplighter, the brother of her grandam Spark. On the turf he won many important races. With one of these my story is connected.

On the night preceding this race a party of New York brokers had a jollification at Delmonico's at a banquet given to a fellow operator, who was leaving on an extended Furopean trip. One of the banqueters, a noted high roller and all-round sportsman, drove home at an hour in the morning not far removed from the break of day. His residence was located on a short avenue running off another fashionable thoroughfare, and he decided it would be impolitic to allow his cabbie to drive to his house and thus run the risk of disturbing his neighbors, two of whon were straight-laced Presbyterian elders. Dismissing cabbie at the corner of the avenue he footed the balance of the journey. As he reached his door the lamplighter came along and turned out the gas in the street lamp inmediately opposite his residence.

The wet night brought the usual dry morning and the broker on his way down town, decided that a hair of the dog that had bitten him would be the best prescription he could take. He halted at his club and over a B. and S. glanced through a morning paper. His eye rested on the list of entries for that day's races. In the list his atten- 
tion was attracted by the name of Lamplighter. "A tip, by George," he exclaimed, and a waiter, hearing the familiar word, came with a rush. He was ordered to call a cab.

Instead of going to his office the broker drove to the railway station and was just in time to catch the "special" to the race track. When the prices were marked up on the race in which Lamplighter was a starter, as good as 10 to 1 was on tap against him. At these odds $\$ 500$ was invested and when this speedy son of Spendthrift (another great race horse) was declared the winner, the broker pocketed $\$ 5,000$.

The glorious uncertainties of the turf form its great attraction. Mr. Hendrie had spent thousands of dollars purchasing the best blood obtainable; yet, after years of skilful study of the breeding question, he was only successful in breeding four winners of the Plate, the other two in addition to those above mentioned being Kelvin and Shimonese. 


\section{THE QUEEN'S PLATE A'T WHITBY IN 1870.}

No denying it, there have been a good many tame runs for the Queen's Plate, but a race there was some year's ago for the blue ribbon of the provincial turf that was worth a long pilgrimage to look at. Where was it, you ask? Why, at Whitby, in Jack Bell's year. Talk abont a surprise party. There wasn't anytling of the kind; it was a regular blizzard that flopped the knowing ones upside down, and turned their pockets inside out. It was the year of Terror's debut, and the popular "White" stable being then under the training control of Dick Leary, it was generally expected that his horses wonld have a little the best of it on the seore of condition.

Again, the afterwards distinguished brown son of Ruric and Maritana, had shown so well in his work and Leary was so satisfied with him, that the followers of the stable looked upon their chances as of the rosiest kind. With Nettie, then in her prime, she was a good judge by which to try a youngster, and when the question was asked, Terror answered so well, that, bar accident, the Plate was considered as already garnisheed. For several days before the eventful one, quite a number of horsemen filed an appearance at Whitby, and on the evening prior to the race, both the eastern and western trains added a large delegation to the list. All the celebrities were to the front, and the Robson House, which was headquarters, was packed like a sardine box.

In the stables connected with the hotel were a good many race horses, and nearly every stall around town was occupied by a thoroughbred. No sooner had the betting men arrived than straightway, trainers and rul,bers were interviewed and every scrap of information seized upon. Charley Boyle's stable was then in its infancy, he having but one string to his bow in Rapid Roan, then and ever since unknown to fame. Leary's 
was the attractive spot, and a close inspection of 'Terror's form only the more strengthened the love of his admirers and weakened the backbone of those who pinned their faith on something else.

When the pool box, presided over by Quimby, opened at eight o'clock in the office of the Robson House, the place was densely crowded and speculation was brisk. The pool-seller's card showed a large entry, it being a certainty that the following ten horses would face the starter: Terror, Jack on the Green, Rathowen, Highland Maid, Gaiety, Rapid Roan, Liberty, Jack Bell, Lady May and New Dominion. The number engaged was sufficiently large to tempt the rural speculators, whose ambition soared no higher than five dollars' worth of anything, and who were content after the picking and choosing had been finished, to take whatever was left in the field, so long as it didn't top the $T$. Terror, as expected, had the call and steadily maintained his position, with Jack on the Green and Rathowen next in order, and the field taking in the balance. The Guelph division was sweet on the last named, and my old friend, the late W. A. Bookless, ably supported by Messrs. Sharp, Dickson and others, snapped him up at his price as often as the cliance offered. During the whole of the evening Jack Bell had gone in the "Field," and about nine o'clock Charley Gates, his owner, strolled into the pool-room and was forthwith badgered by Quimby to select his horse as a "Choice" at some price. Gates objected to any such promotion, but Quimby, despite the objection, knocked Bell down to him once for $\$ 5$ in a $\$ 45$ pool. Even at this figure Gates fought shy and refused the ticket. From then to the close of the evening's business the horse again sold as a fielder, the lot hringing $\$ 5$ in pools averaging about $\$ 50$ to $\$ 60$.

The morning trains on the Queen's Birthday carried large numbers to the county town of Ontario, and at the advertised hour of commencement, several thousand people assembled at the course. Conspicnons on the Club stand were the Hon. John Sandfield Macdonald, Premier 
of the Province; Hector Cameron, T. N. Gibbs, M.P., W. Lount, M.P.P., Sheriff Powell, Sheriff Reynolds, Dr. Andrew Smith, R. Pringle, and many other prominent turfmen from all parts of Ontario. The great race of the day, of course, was the Queen's Plate, and as the ten contestants which sported silk for the event filed round to the starting post, there was a good deal of suppressed excitement. Quimby's voice was echoing far and near, "How much am I offered for first choice? \$20 I am bid and Terror sold," and so on till the drop of the flag proclaimed the Queen's Plate of 1870 then under process of settlement.

The distance was two miles, and before the half-mile pole had been reached the field was pretty well trailed out. On the run up the back stretch Terror got clear of his company and turned into the home run first with two open lengths the best of it. Nearing the stand, at the end of the first mile, Jack on the Green let out a link and moved into second position, and as they swept past the judges' stand Rathowen raced into third place, thus passing the betting box in the order in which they had been sold. But before the next quarter had been reached, a simultaneous shout echoed along the quarter stretch. "Terror is beaten!" "The favorite's gone!" and they had guessed it aright, the colt had hung out the flag of distress and Jack on the Green and Rathowen were fighting for the lead. As they swung round the turn into the straight run, another yell from the crowd proclaimed a second surprise, and sure enough two of the fielders, Jack Bell and Rapid Roan, had left the ruck, closed upon the leaders and at the bushes the four were bunched and it looked a guessing match to choose the winner. But as they levelled from the turn Jack on the Green and Jack Bell got clear, and for a few hundred yards it was a neck and neck struggle, then the latter forged ahead, and as they squared for home showed nearly a length to the good. A punishing finish resulted, but it was of no avail. Bell was full of running, and thus the Queen's Plate of 
'70 was captured by a rank outsider, Jack on the Green second, Rathowen third, Rapid Roan fourth and Terror fifth.

Great was the drop for the betting men and equally noticeable was the rejoicing of the fielders. Very few had selected Jack Bell as the winner, but one of the few whose eye had taken in his form was my old friend J__ E_- of Hamilton, whose purse after the fight looked as if it had the gout; but, oh, what a multitude of wallets were shrivelled up that memorable day. Yokels from "away back" had won the price of a horse with a five-dollar note, and their breeches pockets were double-twisted to prevent the losers from coaxing it away from them the next day. 


\section{MILITARY RACE MEETING AT LAMBTON MILLS IN THE SIXTIES.}

Many a gray-haired grandame of to-day remembers with pleasure the olden times when they were belles of society in Toronto and their most attentive cavaliers were the officers quartered here. Wholesale flirts, those military chaps, who went in for the sweets of life, and were never so happy as when they had half a dozen strings to their bow. Bank clerks took a back seat, professional chaps, either in law or medicine, were consigned to limbo, and the gay-coated and 'broidered gallants were cock o' the walks. The majority of them were also fond of sport, dearly loved a horse race and never let slip an opportunity to try conchusions with the colonists.

Around Toronto in those days were a good many men who had a reverence for the thoroughbred, and they were never backward in accepting a challenge to try conclusions. At the time of which I write the Fourth Dragoon Guards were stationed at Niagara, and the Thirtieth and Thirty-fourth Regiments of the line at Toronto. A race meeting was advertised to come off at the Simcoe 'Chase Course, located just at the top of the steep hill going down to the Howland Mills at Lambton. One of the most important races of the meeting was a hurdle race, of 150 sovereigns, gentleman riders, and this event the Dragoons had expressed themselves confident of capturing, they having entered two flyers then lately arrived from England. The other nominations were Shillelagh, owned by $\mathrm{Mr}$. Beard, of this city, and ridden by Captain Richard Denison; Waverly, ridden by Mr. M. Richards; St. Charles, on whom D'Arcy Boulton had the mount, and Ploughboy (formerly Mingo), owned and ridden by C. E. Romaine. The distance was two miles and a quarter and the jumps, four to the mile, were built 


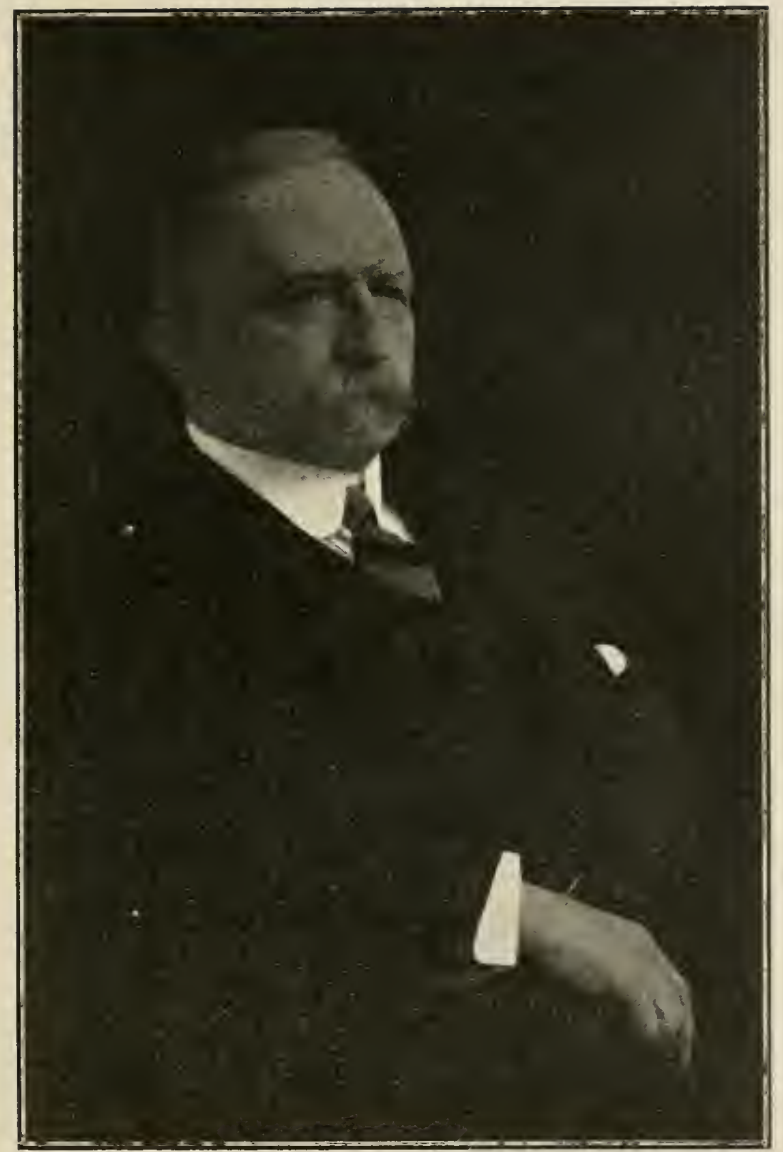

SIR THOMAS G. SHAUGHNESSY, PRESIDENT CAN. PAC. RY. 

of stiff timber five feet high. None of your modern Gimsies that when struck by a hoof fly into fifty pieces and generally wound a horse with the splinters, but genuine old-fashioned obstructions, composed of cedar trees cut down in the immediate neighborhood and with cross pieces bolted through with long wooden pins.

The starter of the race was Captain Markham, who, afterwards as Colonel Markham, greatly distinguished himself in the Crimean war. In fact, most of the troops quartered here in that year were ordered to the Crimea, and the very men who had earned from our people the title of the "Queen's Hard Bargains," were first to achieve distinction on the battlefield. So much rivalry and feeling had been engendered over this particular race and so much money had been staked on the various horses engaged, that on the eventful day fully six thousand people were on hand to witness the struggle. A few minutes prior to the starting bell sounding, Mr. Romaine, on Ploughboy, and Captain Denison, on Shillelagh, indulged in a preliminary canter. The latter horse was the favorite in the betting. He was known to have the speed of the party and the staying qualities to back it, but he was a slovenly performer over sticks, galloping with head down between his knees, and the hopes of his opponents were based upon the chance that he would not "lift" himself over five-feet stiff timber.

Taking a trial jump, Shillelagh did just what was prophesied, viz., failed to rise high enough and struck the cross-bar such a cracker that he came to his knees, but was cleverly recovered by Captain Denison. The force with which he hit caused the end pin to spring loose and the rebound of the stick caught Mr. Romaine's horse in the forelegs and sent him over end, his rider falling underneath and getting badly bruised and cut up. Mr. Romaine was picked up by the late Recorder Duggan and Mr. Robert James, of Homer, and carried into a neighboring tent, where a military medico proposed to bleed him. Mr. Romaine, however, rallied without the blood-spilling operation, and as the saddling bell had 
already sounded, he, assisted by his friends, hobbled out to the weighing room and was lifted into the saddle. Once mounted, no time was cut to waste, the flag. was dropped and the five contestants were on their way.

Nearing the end of the first mile D'Arcy Boulton, on Sir Charles, got a tumble, one of the dragoons flopping at the same time. One of Boulton's hands was so injured that he never afterwards had full use of it. When these horses went down, Shillelagh was away a hundred yards on the lead, and it looked as though the verdict would be the Irishman first, the rest nowhere. Entering on the second mile the positions were Shillelagh first, one of the dragoons second, Waverly third, with Ploughboy as rear guard. Coming to the second hurdle on the last mile, Mr. Romaine, who had commenced to recover from his severe shaking, made a move on Ploughboy, and soon joined company with the "middle division." Once over the jump it became racing speed to the next one, which Shillelagh reached twenty lengths ahead of his followers, but striking heavily he went down a cropper and so ended his chances. There were now left Waverly, a dragoon and Ploughboy to fight it out. At the fall of the favorite not half a length separated the first and third horses. Whips and spurs were brought into full play; the three rising to the last jump as one horse and neck and neck racing for glory. Half way to the winning post Ploughboy got his head in front and after a most exciting and desperate finish captured the verdict by a scant length from Waverly.

The victory was a most popular one and the fact becoming known to the great unwashed that a military swell had loudly expressed his disgust at a gentleman presuming to ride a race in such dress as Mr. Romaine's accident had compelled him to appear in, they straightway made for the offending officer, who, though backed up by his company, found it prudent to beat a hasty retreat. It is calculated that at least ten thousand dollars changed hands on this race. 


\section{A GALLANT OLD-TIME RACF AT TORONTO.}

One day I stumbled across two or three old-timers and many a yarn was unwound as to the doings on the Canadian turf in the days of auld lang syne. One of the company started talking about the celebrated mile-heat race, three in five, that eventuated in Hamilton, and certainly that was a red-hot fight from end to end, and by the time Bay Jack won the sixth and deciding heat of the race, wigs lay thicker on the green than ever was seen in Donnybrook's palmy days.

One of those present, who saw the prolonged struggle, claimed a point better for an old-time race that he had seen in Toronto years before down on Tinning's race course on the banks of the sluggish Don. It was in the days when Mr. Parish, of Ogdensburg, came over here in state, extended a princely hospitality to his Canadian friends, in turn being by them feted and honored. Those were the days when talk about the thoroughbred was a popular theme at Chief Justice Robinson's table and more than one match was made while the legs of the owners were stretched under the mahogany of the popuIar Judge.

In the days alluded to the late Charley Gates was a power on the turf, and it took fast horses and keen judgment to get the better of him. As related, the big race in question was at three mile heats, two in three, and the horses entered were: Colonel, the property of Mr. Parish; Country Maid, belonging to Charley Gates; Phoebe Dodds, belonging to the well-known blind turfman Phil Caswell, and Pilot, the name of whose owner is forgotten. In those days the pool box was an unknown investment, and those who wished to back their fancy walked the quarter stretch and interviewed all comers. One of our present judges was then on the turf and, with 
bank notes in hand, accommodated Mr. Parish by accepting a bet of $\$ 600$ against $\$ 200$, the Canuck giving his love to Country Maid against the Colonel.

The betting was heavy all round, with the Pilot a slight favorite, the Colonel next in demand, and Country Maid and Phoebe Dodds being looked upon as very long shots. The track was fetlock deep in mud, and everyone looked to see a slow, waiting race and an attempt made to win on the post, but the blood of the Colonel and Pilot faction was up and the racing in the first heat looked as if one was determined right at the outset to find out the weak spot in his adversary's armor. The struggle between these two was a red hot one from start to stand, during the whole journey not more than half a length separating the two cracks. On the last quarter the two leaders were head and head and the excitement became intense. "Pilot has it!" "No, Colonel wins!" "Hurrah for Parish!" "Cheers for Pilot!" were some of the shouts that echoed along the stretch. Three lengths from the stand it was still a head to head struggle, but in the last jump the Colonel stretched his neck an inch or two and the verdict was, "The Colonel wins the heat by a nose." Phoebe Dodds was a poor third and the Maid a dozen lengths behind her. So closely matched appeared the two leader's that it was even money on their chances, and the champions of both stables stuck to their representatives like thoroughbreds. Phoebe Dodds and Country Maid were lost sight of. In the second heat all four got away well bunched, but before the quarter was reached the two favorites had left their company and again a ding-dong race was begun. Laying side by side, each jockey watched the other and not for a single jump during the heat was daylight perceptible between the two leaders. One time Pilot would lead by half a length, then the Colonel would let out a link, and so the great struggle was fought out. Coming into the stretch for the run home the Colonel showed a trifle on the lead, and again the air resounded with the mad shouting of the partizans of each stable. At the "draw-gates" Pilot had again got 
on even terms, whip and spur were being used and every art of jockeyship brought into play. Foot by foot, inch by inch, the stubborn struggle was fought out. Staid members of the church yelled like street liawkers in their excitement and even old turfmen were shouting, all ajoy under the excitement. 'Twenty yards from the judges' stand the leaders were locked as if yoked together, shoulder to shoulder, head to head, the two gallant thoroughbreds were straining every muscle to gain the advantage. Within two lengths of the wire Pilot's jockey, by a last supreme effort found out a hidden link and again the verdict was "won by a nose," but this time it was Pilot that was credited with the honors.

So intensely did the two favorites usurp attention that scarce anybody seemed to give a thought that there were any other horses in the race. The betting again became fast and furious between the two heat winners. Mr. Parish, the owner of the Colonel, had over five thousand dollars up on his horse and his friends kept betting until nearly their last dollar was in the stakeholder's hands. When the bell sounded for the third heat all four horses again faced the flag, though the few who had been able during the exciting struggle to note the whereabouts of Phoebe Dodds and Country Maid, declared that they were both lengths out beyond the distance flag and should have been declared so by the judges. But both were so little thought of that even the judges paid no attention to them. When the piece of bunting went down for the start in the third heat, the rider of Pilot, not thinking it a go on account of his being some five or six lengths behind, pulled up his horse and, before he discovered his mistake, the horses were a hundred yards away and Pilot's owner refused to allow his boy to follow. Terrific was the excitement over the untoward circumstance and great was the groaning meted out to the unfortunate holder of the flag for his miserable bungling. The race was now shorn of its interest, for, in the opinion of ninetenths of those present, it was a foregone conclusion that the Colonel would win hands down. So it looked for two 
miles of the journey, as he swept along leading his field by three lengths, but as they rushed by the stand entering on the third mile, the despised outsider, Country Maid, moved from the rearguard and challenged for the lead, amid the breathless excitement of the big crowd, which for a moment was fairly paralyzed with astonishment. Not only did the Maid stand the pressure of a head to head struggle for a quarter of a mile, but actually raced to the front and led the Colonel by a length into the home stretch. Bedlam broke loose couldn't match the scene that then ensued. Men's hats went whirling aloft and Tom Gillespie, of Hamilton, sent his so far and so high that he never set eyes on it again. At the draw-gates the Maid had the heat won, and finished an easy winner by three lengths. The fourth heat; though stulbbornly fought out, was won by Country Maid by three lengths, and thus ended one of the gamest and finest heat races ever contested on any track. It was calculated that fully ten thousand dollars went into the pockets of the greenhorns who had backed Charley Gates' Comntry Maid. 


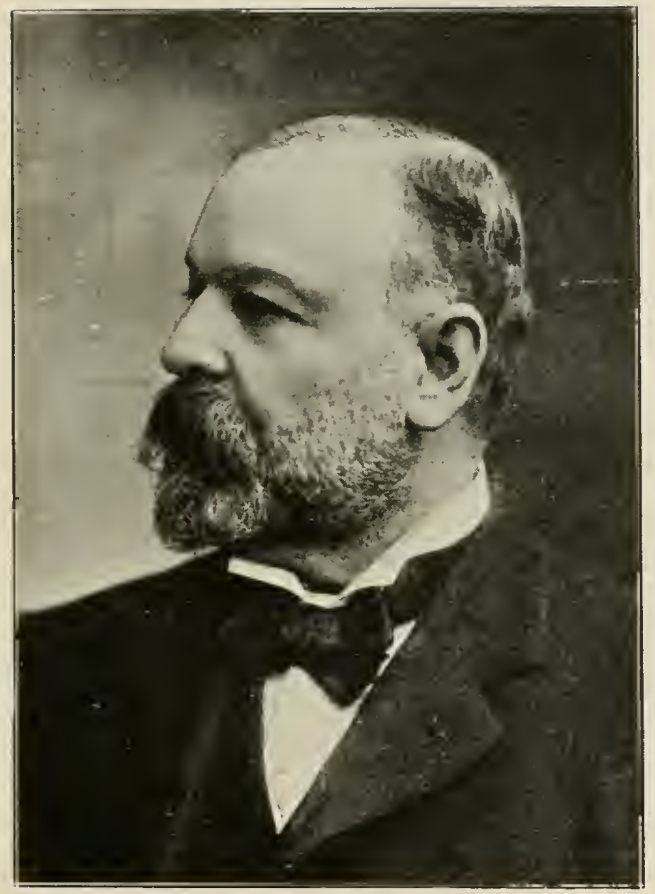

JOSEPH E. SEAGRAM, PRESIDENT ONTARIO JOCKEY CLUB. 



\section{A MFMORABLE RACE MEETING IN MONTREAL IN 1873.}

I propose here to rake up the doings at Decker Park, Montreal, in July of '73. L. W. Decker, then proprietor of the Albion Hotel of that city, had expended a good deal of money in the construction of Decker Park race course and club house, and turfmen of the commercial metropolis were sanguine that at last the royal sport would flourish in their neighborhood. 'These expectations were, however, sadly disappointed. The track was only a half-mile one, and the turns were so abominably sharp that I have seen foul horses go down in one day trying to get around them, and, in addition, the management soon lost the public confidence.

The July meeting I am going to talk about will live long in the memory of western horsemen who were present. Ontario wigs lay thick on the green during the week the fun was in progress, and every effort made by the western men to recover themselves only dropped them the deeper in the mud. The first instalment of bad luck was secured in the hurdle race, the opening event of the meeting. The horses engaged were Notary Public, Old Rye, Jack the Barber and Ivanhoe. Jack was fresh from his western triumphs, showed in good form and temper and was, therefore, in his present company, booked a certainty, but like the majority of "sure things" it wasn't pulled off, both of those old pelters, N. P. and Old Rye finishing ahead of the favorite.

In the next race, the Ottawa Hotel Stakes, mile heats, the starters were Mr. Barber's Carleton, Lord Byron and Vespucius. The chaps from the West stuck to their representatives, the two latter, and were about equally divided in opinion as to which was the better horse. The first heat was captured by Vespucius, and he was at once 
installed a red-hot favorite over the field, but in the second Ottawa's representative clouded the prospects by galloping home an easy winner in faster time than the first heat was run. Still the boys remained true to their first love and loyally snapped up the offers made by the backers of Carleton, who, in the third heat, astonished his opponents and surprised his friends by galloping home an easy winner in the fastest heat of the race.

Thus was received facer number two. In the third event, the Sapling Stakes, the victory of Dr. Smith's War Cry put back a few of the scattered shekels, but the defeat of Mr. Stanton's Storm on the second day in the Hochelaga Produce Stakes, by the Donnybrook filly, struck the already weakened ones with the force of a hurricane, and so demoralized them for the time being that they hadn't the nerve to back Vespucius for a dollar against his conqueror of the preceding day, when they came together in the Merchants' Plate, which was one of those relics of barbarism, mile heats, three in five. Carleton was a warm first choice, but he never had a show, the old chestnut cutting loose and capturing the trick in three straight heats. Had this victory been played, all previous losses could have been recouped.

Inspired and encouraged by the turn of the tide, the western contingent again rallied to the pool box and right royally backed War Cry against The Moor in the mile heat contest, and àgain for their devotion they were rouchsafed their third facer, Montreal's champion winning the event in two straights. Sadly discomfitted, the unfortunates retired for the time being to figure up their losses and scheme to get even on the third day. The opening event of it, however, proved another Waterloo. Mitchell, who on paper figured a certainty, was warmly supported, but only succeeded in scoring second honors, and in the very next race the western favorite, Lord Byron, went down before C. O. D. and Frank Swift. "Alas, woe is me," was the mental refrain of many an Ontario sorehead. This last was the finishing straw that broke the camel's back and, disgusted with the rum of 
luck, they hadn't nerve enough left to back a race horse against a mule.

On the last day a ray of sunshine illumined the gloom by the victory of Jack Vandal in the Montreal Hotel Stakes, and the success of Fisher and Carson's Neptunus in the Flash Stakes, but the long odds in their favor choked off all speculation. Thus closed one of the most disastrous meetings for backers of favorites I ever remember to have been at. The only winners were those who bought the cheap ones, tickets not bought on judgment, but purchased simply because they were cheap. Many were the drafts drawn to make good in the box and equally numerous were the long faces that were drawn as the proceeds were paid out. 


\section{A SPLENDID MEETING AT CARLTON PARK IN 1874.}

Some writers in dealing with the career of the late T. C. Patteson credit him with being the first person to inaugurate racing in this city. Now, while I am desirous of giving every possible credit to a gentleman who was the recognized authority in this country on the history of the thoroughbred horse and was perhaps better posted than any man on the continent on the pedigrees of English horses, they are astray in their statements respecting his being the pioneer in flat racing hereabouts.

Many years before Mr. Patteson took a hand in the game the officers of the Thirtieth Regiment and of the Hussars, then stationed in Toronto, promoted horse racing and several interesting meetings were hold, both on the Bolton course and on the present Newmarket track: Outside of what may be called the military meetings, the writer was the first to endeavor to revive interest in the royal sport among our people.

He gave a meeting at Carlton Park in 1874 when such purses as these were hung up: For Dominion-bred horses, $\$ 400$, mile heats, two in three; Flash Stake, 100 pounds up, dash of one mile, $\$ 250$. This was won by Trouble, his first victory, but he afterwards became the recognized champion steeplechaser of America. Hotel Keepers' Purse, open to all horses, $11 / 4$ mile heats, $\$ 500$; hurdle race, $\$ 400$, two miles; Toronto Purse, one mile heats, $\$ 450$; Lambton hurdle race, $\$ 350,21 / 2$ miles; Ladies' Purse, a dash of three-quarter mile, \$300; Citizens' Purse, $\$ 400$, mile heats, two in three; Consolation Purse, $\$ 200$, a dash of $1 \frac{1}{4}$ miles. This is a total of $\$ 3,850$, and considering the circumstances under which the meeting was given, it was a more hazardous undertaking than it would be to hang up $\$ 50,000$ at Woodbine 
at the present day for a meeting extending over ten days. At the time I speak of there was no fence around Carlton Park. It was practically an open common. True, there was a snake fence along some portion of it, facing on the Dundas road, but it was in a dilapidated condition and any person could get over it. The stand, capable of accommodating at the most three hundred people, was a ramshackle affair that had stood the blasts of many winters and the warping heat of many summers. An admission fee of twenty-five cents was charged, and pretence for a gate was made in the shape of stretching a long bar across the lane leading up from the highroad to the track.

It was calculated that on the opening day fully eight thousand people were in attendance, and notwithstanding the unprotected condition of the course, over four thousand people were decent enongh to go the long way round and pay their twenty-five cents to enter. The horses when finishing had to run through a living lane for fully two hundred yards up the stretch, running southward from the stand, as several thousand people had gathered and fringed the course a dozen deep on either side. It became necessary before every finish for the mounted clerk of the course to gallop up and down, begging the people to fall back. They good-naturedly acquiesced, and not a single accident marred the sport any day of the meeting. Pools were sold in the city at the Terrapin Restaurant, then located on King street east, immediately west of where the Albany Club is now located. Pool selling on the track was also very heavy. At the meeting alluded to the returns were made by Messrs. Quimby, Forbes and Page. The total amount sold figured up to $\$ 49,865$.

The great betting race of the meeting was the mile and a quarter heats, won by Lady Washington. On this race alone over $\$ 15,000$ was wagered, some of the representative men of the city standing in front of the auctioneer and betting $\$ 200$ and $\$ 300$ for first choice, some of the pools filling to $\$ 500$ and $\$ 600$. 
"Gus" Thomas, then proprietor of the English Chop House, now a retired capitalist, was in those days one of the most ardent followers of the 'chase. He rode at this meeting in one or two of the jumping events and came mighty near passing in his cheques. His horse fell and rolled over on top of him, and before he could be extricated the animal gave him the full benefit of his weight. Only the deep sand on the track and the sparse form of the rider saved him from being flattened out like a pancake. He was picked up in a badly damaged condition, put into a cab and driven quickly to the city. He was confined to his room for about a week, when he reappeared somewhat the worse for wear, but still game enough to go over the sticks again.

The expenses in connection with the meeting were heavy. The writer had a large tent erected for the accommodation of the officials of the Club and their invited guests, the members of the Toronto Hunt. About eighty gentlemen partook of his hospitality, among them being many of the representative men of the province.

The officials of the meeting were: Sir Cassimir Gzowski, the Hon. D. L. McPherson (afterwards Sir David), Mr. Hector Cameron, Captain Elwes, the Hon. C. I. Douglas, Dr. Andrew Smith, Angus Morrison, M.P., Hon. John Beverley Robinson (afterwards LieutenantGovernor of Ontario), and several others whose names have escaped my memory.

Of all these enumerated, how few remain. The list includes the names of some of the boldest front riders that ever wore a huntsman's coat. Nearly all have ridden their last race, and to-day their names are but a memory. Those of the old guard who are here cannot recall the enjoyments of past days on the Canadian turf without a feeling of sorrow for the many good men and true that have dropped by the way.

Though much pleasure was taken out of racing in the days of yore, there was not much profit. The almighty dollar was not appreciated then quite as much as it is at the present time. The sons of Israel had not swarmed 
upon the race course trying to occupy every corner where a nimble dime could be made. Men went to the races, not altogether to bet money, but to meet their friends and enjoy a pleasant time. The enjoyment was great, but the profits were small. The balance sheet at this Carlton Park meeting, after all expenses were paid, showed a profit of $\$ 79$. Yet, strange to say, it was then considered as satisfactory when the income balanced the expenditure. Truly the times have changed. There is now a different class of owners and the present ones are nearly all out for the dollar. 


\section{THE MISTRESS OF CRUICKSTON PARK.}

It affords me profound pleasure to present in my "Recollections" a portrait of a lady whose name and personality have been more discussed in Canada than that of any other within this broad Dominion. Miss Katherine L. Wilks, of Cruickston Park, Galt-a member of the great Astor family of New York-has by birth and wealth the entree to the most exclusive society in America, yet she prefers the attractions of her Canadian estate of over one thousand acres to those of a mansion on Madison Avenue. A woman of culture and refinement, the social pleasures and diversions that satisfy the majority of her sex, have for her few attractions, though the doors of Cruickston Hall are ever open to a wide circle of friends, where, as lady of the manor, she dispenses graceful and boundless hospitality. There are noble dames in the Motherland who have gained distinction in the horse world; prizes in the show ring and at horse shows attest the interest they take in the development of the equine race, but the position occupied by Miss Wilks is much more unique. Her taste, fortunately for the horse-breeding interests of Canada, inclines to the light harness horse, and in furtherance of her fancy she has within a few years spent an enormous amount of money. Yet, strange to say, the rock upon which eighttenths of the amateur horse breeders of this country have wrecked their hopes, this lady, possessing none of their business experience, steered a safe course and the result has heen a gratifying success.

Her principle of action has been eminently clever; aiming as she did to secure the best results, she at the commencement of her venture recognized the important fact that quality begets quality and that can only be obtained by buying the best, regardless of its cost. It was this sound reasoning which induced her to pay $\$ 15,000$ for 


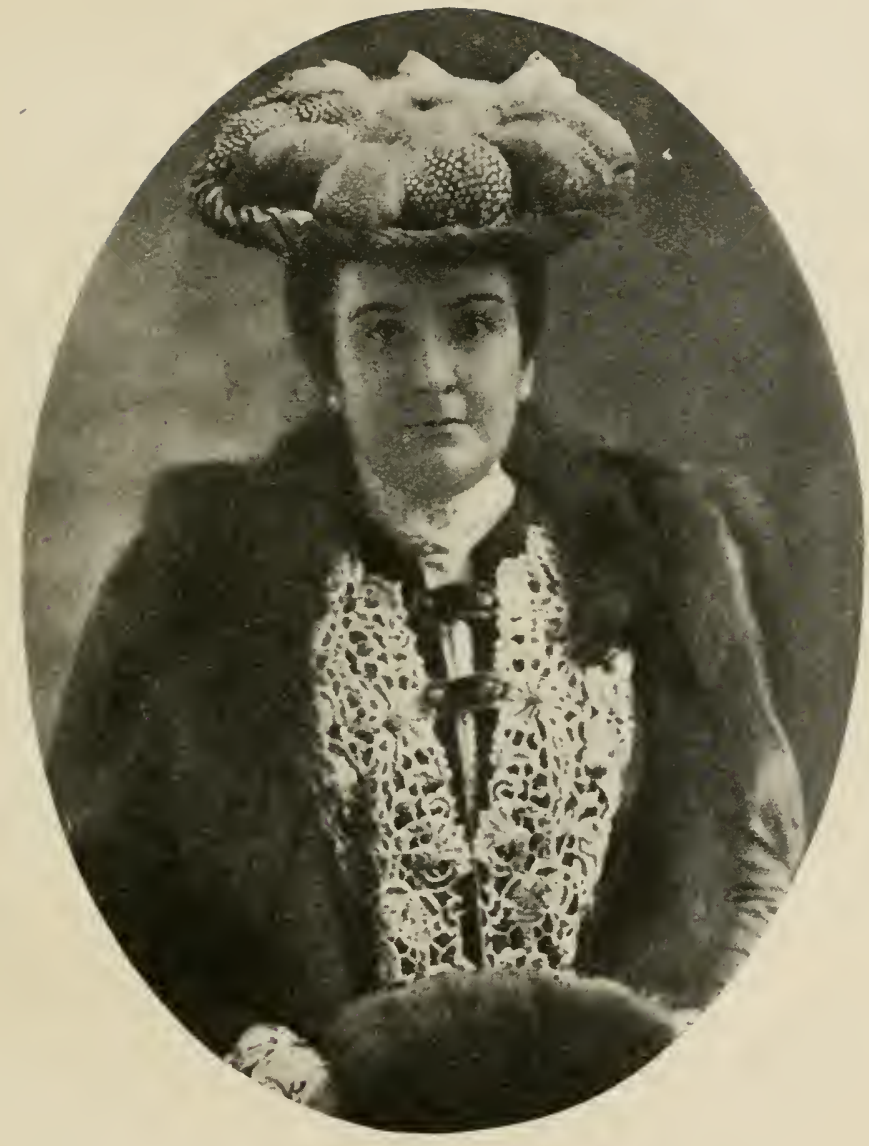

MISS KATHARINE L. WILKS, CRUICKSTON PARK, GALT, ONT. 

the lamented Sadie Mac. It was the highest price realized at the great New York sale, and it was the highest price paid for a mare in America during 1904. Miss Wilks' judgment was brilliantly justified early in the summer of the following year when Mr. Smathers, of New York-the former owner of the mare-sent an agent who offered her $\$ 30,000$ for the return of his favorite trotter. The offer was refused, and again many of the shrewdest horsemen on the continent thought the Canadian owner had made a serious mistake in declining such a princely bid. Again results proved her judgment correct and the critics in error. Sadie Mac, until that fatal day at Hartford when she dropped dead in her race, was the bright meteoric equine star that outshone all rivals on the Grand Circuit. It was with Sadie Mac a mere question of health to annex all the great stakes in which she was entered. The best trotters in the land had joined issue with her, yet each and all were disposed of with such consummate ease that every trainer and driver on the Grand Circuit recognized and admitted that she was in a class by herself, but now an earthen mound within the enclosure of the Hartford track marks the last resting place of Cruickston's famous mare.

Cruickston Park is one of the great show places of Ontario. Situated in the heart of one of the richest agricultural districts in the province, its fertile fields, forest-crowned hills, lovely valleys and superb avenues bring to the mind's eye recollections of some of England's beautiful country seats.

The question will naturally arise in the minds of many people: Does Miss Wilks take much personal interest in her horses? My reply is that she is apparently acquainted with every one of the seventy-five to one hundred, young and old, that own her as mistress. She is a rarely good judge of conformation, has a keen, quick eye to detect faulty action, and is a clever, fearless driver; whether holding the reins over her favorite mare, Lady Cresceus, or sitting behind her world's champion team, Rhea W. and Easter Bell, driving at a four-minute 
or a two-twenty clip, there is the same easy poise, the same steady hand and the quiet self-possession that not only perfectly controls the animal she is driving, but imparts that spirit of confidence without which, between driver and horse, there can be no perfect action.

Cruickston Park is a beautiful place at any time of the year. In summer, when its towering elms and beautiful maples are in full dress, its avenues and spacious treeshaded lawns are lovely rambling grounds, but on that autumnal day, when I both walked and drove about the estate, it had a charm equal to its summer splendor. The magic wand of King Frost had painted the leaves in colors more exquisite than the hand of painter ever wrought or poet ever dreamed of. Purple and gold, jasper and emerald hues blended the whole landscape in a glowing, brilliant scene of surpassing splendor.

Standing on the lawn close to the residence my eyes took in a scene than which there is none fairer in Ontario. Over one hundred feet below lies the valley of the Grand River which, like a silver ribbon, winds its tortuous course lakeward. There, it is a broad, deep river which, if properly guarded, would afford splendid sport; the gamey bass once flourished in its waters, but the despoiler has worked his way unchecked, and these attractive stretches have been nearly fished out. Eastward three miles the lofty chimneys of Preston's many flourishing mills and factories mark the sky, while to the southward the town of Galt bounds the vision. Meadow lands along the river bank, gently rising upland, a rich agricultural district pleasant to look upon and one of the most prosperous in the Dominion. Here and there belts of timber resplendent in their antumnal robes brighten the whole landscape under the sun's rays with magic beauty. The estate includes about 1,100 acres, and though a goodly portion is under cultivation, the forest has been carefully preserved so that a nobly wooded park surrounds the residence. Black squirrels and partridges are fairly numerous, but nothing in comparison with what might be if the poachers would but respect the efforts 
of the owner whose desire it is to protect them for a few years that they may multiply and spread over the whole neighborhood, but so little encouragement is forthcoming that one wonders Miss Wilks has not long ago abandoned all efforts in the direction of game preservation. 


\section{A GOOD PERFORMER THIRTY YEARS AGO.}

I was asked one day which horse I thought was the best general performer on the Canadian turf thirty years ago, and the name Lord Byron by Kentucky-Lady Blessington, came to my mind as the one I thought had a shade the best of it, but my friend, though he remembered the horse named, scarcely considered him to be as good as one or two others that were running at the same time. Since the time that I answered the question off land I have thought the matter over and am still more satisfied that my first impression was correct. I remember back in 1873 seeing Lord Byron start at the London June meeting and win a good race, a dash of one and a half miles, carrying 115 pounds, and beating Neptunus, Judge Durell, Harper, Lottie B. and Puss Harris. Twenty minutes later his owner, James O'Neil, started him in a two-mile dash and won that also, beating Kelso, Longueil and Judge Durell in the order named. On the following day he was again started in a dash of two and a half miles, which he also won, beating Longueil and Judge Durell. This was three races in two days, or a total distance of six miles, and I fail to remember any other horse in the earlier history of the Canadian turf who could show such a creditable record for speed and gameness. He won numerous other good races the same season and finally broke down, if I mistake not, at Carlton.

As a proof that the old clubs in Ontario were very liberal, considering their means, thirty years ago, I will just quote a programme drafted by the writer for the Barrie Turf Club in May of that year: Hurdle race, $\$ 250$; Ladies' Purse, \$700; Hotel Keepers' Purse, \$400; Northern Railway Purse, $\$ 500$; Canadian Derby, $\$ 400$ added; The Kempenfelt Stake, $\$ 500$; Lumbermen's 
Purse for Dominion breds, $\$ 400$. Certainly this bill of fare thirty years old compares favorably with the programmes of the present day, and the revenue derived in those days at a meeting was insignificant in comparison with what is obtainable now. At the meeting alluded to my old friend Roddy Pringle won the Queen's Plate with Mignonette; Charley Boyle running second with Norlander. Dr. Andrew Smith scooped in the Kempenfelt Stakes with Edenton and the Canadian Derby with War Cry. Clem Alloway, one of the very best gentlemen riders that Canada ever produced, won the Hotel Keepers' Purse with Rainbow. Dear old Joe Grand landed the Northern Railway Purse with Jack the Barber, and O'Neil won two races with Lord Byron. It was a thoroughly pleasant meeting, and the Toronto contingent, numbering several score of good sportsmen, all gathered at Barrie the evening before the meeting started. Each hotel in the place was crowded with visitors and everybody seemed to enjoy the sport. 


\section{JOKE ON DR. ANDREW SMITH AND DAVID ALEXANDER.}

I have chatted elsewhere about the fun a few of us had with "Major" Quimby at Whitby over his appointment as official pool seller at Saratoga, and I'll now tell a little story about what happened in the same town the following year at the expense of two of the present members of the Ontario Jockey Club. A big party of turfmen were seated on the verandah of the Robson House, passing the time away after dinner before starting for the track. Dr. Andrew Smith, then Principal of the Ontario Veterinary College, David Alexander, Roddy Pringle and the writer were sizing up some of the afternoon candidates when suddenly the whole party were startled by a couple of newsboys who, with a Chiffney rush, landed in our midst shouting: "Gazette extra. Great fire in Toronto on Temperance street. The Veterinary College in ruins and a lot of race horses burned." Dave Alexander, who had just made his first investment in the race horse line, by buying of Dr. Smith a half interest in the steeplechase mare Helen Bennet, jumped to his feet and, thoroughly excited, urged the Doctor to order out the horses and start at once for home. Friends on all sides commenced to tender their sympathy and express the hope that everything was insured. Finally, after everybody had worked themselves up over the fire and several telegrams were being prepared asking for further particulars as to the disaster, we let the cat out of the bag by owning up that we thought a little shock would do both the Doctor and Alexander good after the loafing they had indulged in for forty-eight hours, waiting for fair weather to bring on the races, and in consequence had set up the job, got the special despatches printed and hired a couple 
of smart boys to play the act out. It cost the couple many a dollar to drown out the recollection of that fire, as the kidders were as numerous in those days as now, and one posting another a never-ending procession of enquirers were going up all afternoon at the track and asking for information as to the extent of the disaster. In those days the ordinary cost of setting them up in the country was four for a Yorker (twelve cents) and the whole bar for a quarter, and even with a due regard for the truth, I'm forced to express the opinion that if all the people my two friends treated that day had been drawn up in line, they would have made a procession many leagues in length. 


\section{A THOROUGHLY HONEST TRAINER.}

Poor old Frank Owens, who trained for the late Mr. J. P. Dawes for so many years, was called a crank, and he certainly was built a little on the cross-grained order, but I very much doubt whether any of us would be any sweeter dispositioned than he if we labored under as many physical disabilities as afflicted him all his life.

It was at times very painful for him to hobble around, and a man handicapped in such severe fashion has, in my opinion, a legitimate right to grumble and kick at the weight of affliction imposed upon him. True, the goodygoody doctrine is that no matter how much you suffer, it might be worse, therefore, bear the affliction you have without grumbling. That's very well in theory, but it does not pan out in practice, and it's human nature pure and simple for a man to get short-tempered and use an occasional strong word if every bone in his body is aching and he is unable to take a single step without feeling that a few gimlets and bradawls are working within him.

But I didn't start out with the intention of furnishing a chapter on Frank Owen's physical disadvantages. I merely desired to direct attention to it, thus, I think, amply justifying any crabbedness of temper that he may have displayed at times to those who read these pages. Poor Owens trained many a winner, but he finally weighed out himself, and though many a more pious individual has answered the last roll call, I would just as soon stand by the chances of old Frank in the Kingdom Come as some of the more pretentious psalm-singing crowd who love to toot their horns in the market places, for I know Frank Owens, with all his fanlts of temper, was an honest man, and there's a goodly proportion of those professional Christians who wonld stand a mighty 
poor show if the guardian at the gate is sternly strict on that qualification.

I have said that old Frank was thoroughly honest, and in proof of that declaration I am going to spin a little turf yarn that is known to but very few. Even my friend Dawes knew nothing of it until nearly a year after it occurred. It was back in 1885 , when the stable's two crack jumpers, Rose by Helmbold, dam by Niagara, and Charlemagne by Pat Malloy, out of Alice Burford, were carrying everything before them. There was a gang of pirates then, as now, connected with the jumpers, but the great stumbling block in their way was the Canadian stable, whose horses were always trying for the money.

At the Monmouth Park meeting a very prominent gambler who played the jumpers heavily, made up his mind to interview Owens and see if he couldn't fix him. Early on the morning of race day he sauntered round to the Dawes stable and, watching his chance, finally secured an audience with the old man. He did not beat about the bush at all. He was one of the kind that believed the almighty dollar a more potent argument than any amount of special pleading; so as soon as Owens sat down his visitor drew ten one liundred dollar notes from his pocket, and laying them on his knee, said: "Frank, T've brought this thousand over for you.",

"Brought them over for me," replied the old man. "Well, you are a mighty liberal man with your money. Why do you want to make me such a big present?"

"I'm not wanting much, Frank," was the answer. "I merely want the privilege of putting up a jockey on Charlemagne to-day."

The old man hung back for a second or two, then quietly said, "It isn't much of a privilege you are asking for so much money, but perhaps if I let you pick out a rider for the chestnut horse to-day you'd be wanting to give the boy your orders how to ride the race, too?"

"Oh, certainly," was the answer, "I'm offering you the thousand dollars just for that privilege, nothing more." "Then you d—d scoundrel, you get away from here. 
If I was to take your money I'd be ashamed ever to look the boss in the face again."

And the gambler knowing now that it was impossible to corrupt the old cripple, went out, fixed the other horses starting against Charlemagne and played the Canadian horse down to 5 to 2 to win, thus raking in sure money.

There is no doubt that $\mathrm{Mr}$. Dawes occasionally won races through that sort of work being played by the gambling fraternity. The gang, finding that 0 wens was incorruptible, often laid their plans to make a sure thing by "stopping" other horses and playing their bank roll on the Lachine stable. In this connection a very good story is credited to Meany, the well-known cross-country rider. He was riding one of Mr. Dawes' jumpers in a steeplechase, winning with consummate ease, and when asked by Owens after he weighed out how he got along, he chuckled out the following:

"Get along, Frank, why divil a nicer ride I iver had in all my life. Such nice plisint gintlemen, I never met before. When I'd come to a lep, they'd all pull to one side as much as to say, 'we wish you safely over, Meany,' and be me soul I think they did. They just shoo'd me along, as it were."

Meany sized the situation correctly. They were all backing his mount. 


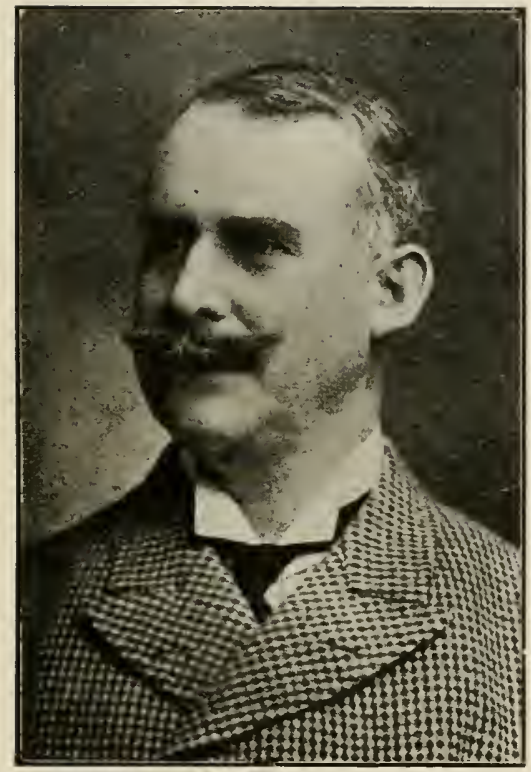

LIEUT.-COL. HON. J. S. HENDRIE, HAMILTON. 



\section{YE OLDEN TIMES.}

A visit from Secretary Fraser of the Ontario Jockey Club one day, who wished to refer to the files of The Sportsman to fortify his mind respecting the antiquity of some of the fixtures of the Club he so ably represents, started my memory jogging back twenty years or so to the days he desired to refer to. Some of the first names that canght my eye were those of John Forbes, John L. Quimby, Sam D. Page, Ras and Lean Burgess, Charley Boyle, Pat Farrell, George Forbes (champion 150 yards runner of America), nearly all of whom were residents of Woodstock-then the Nerwmarket of Canada, now only a sleepy hollow in connection with racing matters.

There was a very warm bunch at Woodstock in those days and there was no game from pitch and toss to parlor croquet that they wouldn't play and bet on. Woodstock conld a little more than hold its orn with any other burg in Canada at pigeon shooting, foot racing, trotting, running or any other game that might he proposed. Judge Finkle was then interested in the thoroughbred game. He owned a few real good ones and was never so happy as when watching one of his own breeding perform. Mr. Millman, another resident of the Oxford county town, also owned a few good horses.

When I think of some of the owners and turfmen who used to foregather in the seventies, they'd pan out with the hest of the present-day lot: Joe Grand, John Hendrie, C. I. Douglas, Major Peel, Jack Munro, W. A. Bookless, Jos. E. Seagram, Dr. Andrew Smith, Dr. Morton, Roddy Pringle, James White, John Stanton, Archie Fisher, John Shedden, and so I might go on at great length, but the retrospect is a sad one, hecause of those I have named nearly all lie under the turf they loved so well. John Forhes, the first named, though a man of robust consti- 
tution and of that stocky, sturdy mould that would make one willing to wager odds that he would easily pass the scriptural three score years and ten, was cut down in his prime, and Lean Burgess also dropped by the way. Poor Sam Page is also a memory, and Quimby was found dead in bed at Saginaw, Mich. Charles Boyle is still alive, and he, I am pleased to hear, is fresh as paint and looks tough as a knot of second growth hickory.

Really there has not been much growth in the Canadian running turf during the past quarter century. I do not believe there are as many Canadian owners of thoroughbreds now as there was then, and I am quite sure that for genuine love of sport the old timers could give cards and spades to the modern dollar-worshipping owner. Whether there has been as much improvement in the quality of the horses as some latter-day people would have you think is an open question. Modern ways of training and faster tracks are responsible for a good deal of the so-called improvement, but such old-time performers as Nettie, Terror, Disturbance, Jack Vandal, Emily, Bonnie Ino, Lady D'Arcy, Jack Bell, Jack on the Green, Bay Jack and lots of others would be in the money to-day under the present circumstances. Mile heats over bad half-mile tracks in 1.48, 1.49, was smart work, and I would back the timber-toppers of that time to carry pound for pound and hold their own with the best of the present day, and I think a few I could name would be top-notcher's now.

What about Milesian, winner of the double event over McDougall's farm, back of the mountain at Montreal; it was a good day's sport. The son of Mickey Free beat a field of twelve in the Club steeplechase, three miles, and forty minutes later with 174 pounds on his back, galloped away with the open steeplechase, four miles, beating thirteen others, the nearest horse not being within two hundred yards of him, and there was some real good material among his followers. There were some rasping good timber-toppers then: Jack the Barber, Pilot, Mitchell, Grey Cloud, Kelso, Viley, Cataract, Tradewind, 
Rose and Charlemagne were a powerful combination that could pack the weight and go any distance within reason. Horses were thoroughly schooled in those days. Owners did not try to make a steeplechaser in two weeks, and the result was a lot of horses that could jump stiff timber and do it in a clean-cut, workmanlike fashion.

Some of the present-day "know it alls" will tell you that the quality of the old-time sport was away down; don't believe them. They prattle of something they know nothing about. They pretend to think that jobbery then ruled supreme, but there was less temptation to go crooked in those days than now, and the racing in the seventies and eighties will bear favorable comparison with the strictest-managed meeting of the present time. There was a little more sentiment then and less of the almighty dollar combination. Men did not pronounce judgment on the success of a meeting by the amount of money they won and turfmen were ready to gather together and enjoy a pleasant social time, open a cold bottle and not shout "thief, thief," when beaten. 


\section{TERROR'S GREAT RACE AT OTTAWA.}

When one's memory travels back early in the '70's and calls to mind the many successful running meetings that were held at Ottawa, it seems strange that the sport should have so completely died out at the Capital. In those days the races at the eastern city ranked amongst the best, and large numbers of sportsmen were wont to assemble from all over Canada to take a hand in. The rich lumber magnates from up the Ottawa would meet there and when they had a fancy they would back it with a persistency that generally beat down all opposition, and though they lost perhaps oftener than they won, they always came up smiling for the next round.

I have seen a local race there, one open to the counties of Leeds, Russell and Pontiac, create as much excitement as a meeting of the cracks in stakes worth thousands, and on one of these races I have known over six thousand dollars go into the pool hox, and I also eall to mind a bad case of pulling. I once saw a Queen's Plate awarded to a horse, when to allow him to win it was necessary to pull another horse all over the track, and though the pulling and yanking was done all down the stretch, everything went and the Governor General, who was present, was asked to award Her Majesty's guineas to the chap who got there first. I have seen some strong arm work in my racing days, but I never yet saw anything quite so barefaced as that Ottara Plate, and I have often wondered whether the three judges on duty had condensed goggles on, that only covered the radius in which the leading horse was travelling. deep in the hole, it was only good sense to try a change.

At the last moment permission was given to do it and at once we hunted up Mat Williams, and after a bit of hard work induced him to take the mount. He had a 
very tired horse to deal with, and though he possessed more speed than any horse in the race, he had been made so much use of that it was a question whether he could be nursed along within striking distance and then trust to his gameness and speed at the finish. Williams rode that heat with his head; he let the other horses do the breaking away. He kept still, and when the flag did go down he laid back in about fourth place and let the leaders fight between themselves. It one time going up the back stretch he looked to be ont of it, but he was patiently hiding his time, and no statue ever rested on its granite base steadier than he on 'Terror. At the head of the stretch he improved his position a little, but it was not until within two hundred yards from the finish that he cut loose in earnest. Terror was a horse that cared but little for the spur, but with a man able to make him feel the whip, he would respond every time with the courage of a bulldog. Williams knew this, and never in his career as a jockey did he work as in that finish. Concentrating all his strength and energy for the rush, he called upon his horse with both whip and spur and gained at every jump. Every man and every woman was on his or her feet, and a yell worthy to rank with that of the old Kentucky cry, bespoke the excitement of the people. Twenty yards from home he had a full neck the worst of it and his horse looked to be done, but at this critical moment he called upon his mount for a final effort, and even as the sharp swish of his whip clearing the air sounded upon the ear they swept past the stand, and not one man in that great throng could tell who had gained the verdict. but when the judge announced: "Terror by a nose,"

The best race that the well-known provincial "Terror", ever ran was orer the Ottawa track. It was one of those old killers, mile heats, best three in five, and there was quite a large field of contestants, though I only recollect Terror, Rathowen, Storm, Ruby and Ivanhoe. Every horse was out for the money and it was one of those races often won more by the headwork of the jockey than by the speed of his mount. Terror was the hot favorite. 
In fact, prior to the start he ranked very nearly even against the field, and after he had won the first heat it was any odds on him with very few takers of the other end. The boy on the favorite was, however, a poor jock and quite unable to ride to his orders, which were to take it easy the second heat and not distress his horse racing against the whole field for the lead. He, however, did the reverse of what he was ordered, and though he managed to win the heat, the favorite was very much distressed.

His owner, Mr. Jolnn White, then M. P. for Halton county, was present, and a few who had backed Terror heavily at good odds were anxious to have him change jockeys, but he was a particularly stubborn man and positively refused. In the third heat the young fool took the favorite off on the lead and again raced his head off, with the result that he finished either third or fourth. Again a strong deputation urged Mr. White to put up another rider, but he was adamant as before and the disappointed ones immediately rushed for the pool box and tumbled over one another trying to hedge out their money regardless of the odds they had to pay to do it. The writer had backed the favorite, but before doing as the others, he and a friend tried their hand on the stubborn M. P. We did not hesitate to tell him that he had not one chance in a thousand to win with his own boy up, and as the first money was $\$ 300$, and his friends were all then the pent-up feelings of the crowd found vent in cheers, and as the tired favorite returned the scale, horse and rider received an ovation. It was one of the most brilliant bits of riding ever seen on a Canadian race course. 


\section{SUPERSTITION AND LUCK.}

At different times I have written about luck and superstitious belief, citing cases of well-known turfmen who, on race days, were ever ready to be impressed by circumstances which at another time would not for a moment arrest their attention. Poor Doctor Coleman, a few of whose doings I have chronicled elsewhere, would never, even by those who knew him most intimately, have been called a superstitious man; yet I remember on one occasion when passing with him through the gates of Mutchmore Park on race day, meeting a squint-eyed citizen face to face. That settled it in the Doctor's mind. He declared he could not win a bet that day, and though he tried it in four out of the five events that colored the card, he never selected a winner.

Uncle Joe Grand, whose jolly, bluff, hearty manner and mirthful mind was not streaked to any preceptible extent with superstitious belief, would go two blocks out of his way on race day to avoid meeting a cross-eyed man or woman. Major Peel, at one time known to nearly every racing man in Canada, would not bet a cent on a race if he happened to hear a cock crow late the night before. Here's a question for you that you can all answer: How many of your acquaintances will walk under a leaning ladder without flinching? It does not require a race meeting to make them shy of that deal. I stood one day at the corner of a street in Toronto for fully fifteen minutes to settle a wager $I$ had made with a friend on the same suhject.

I bet him a "bottle," never mind what was to be in it, that two out of every four men who passed down Yonge street would dodge the ladder leaning against a building. The bottom of the ladder reached to within three feet of the outer edge of the sidewalk, so that it was a deliberate shirk if a fellow selected the narrow path 
around. The first pedestrian to pass by was a wellknown, self-made man-one of the kind who worships his creator. My old friend had scarce time to remark, "there goes an old duffer that never dodged anything in his life but a beggar or a subscription sheet, see him go under," but old moneybags didn't go under. With a quick glance upward he slipped to the curbstone and passed around, glancing about at the same time to see if his shirk had been noticed. The occurrence rather disheartened my friend, and when five out of the next six passing did the same thing he called "enough" and straightway settled the wager.

That rare good pattern of an all-round sportsman, the late William Bookless, of Guelph, would stand anything on earth but a black cat. Great Scott! if one of that kind crossed his path about racing time, he had not a particle of confidence in his ability to guess anything right. Poor Jack Mumro had a holy horror of being passed by a redhaired woman when he was bound for the races, and I remember once when driving with him from the Russell House, Ottawa, to the track, Jack suddenly called to the dxiver to pull up, but before the order could be obeyed he had the cab door open, jumped out and ran into the hotel we happlened to be passing, all, as he admitted, to save heing passed ly the red-haired girl who was driving towards us. The late John Forbes had a prejudice against yellow dogs, while his partner, John Quimby, would rather walk a mile ont of his way than meet a colored girl on his way to the track. All of which goes to show that ridiculous ideas will sometimes influence the humall mind. 


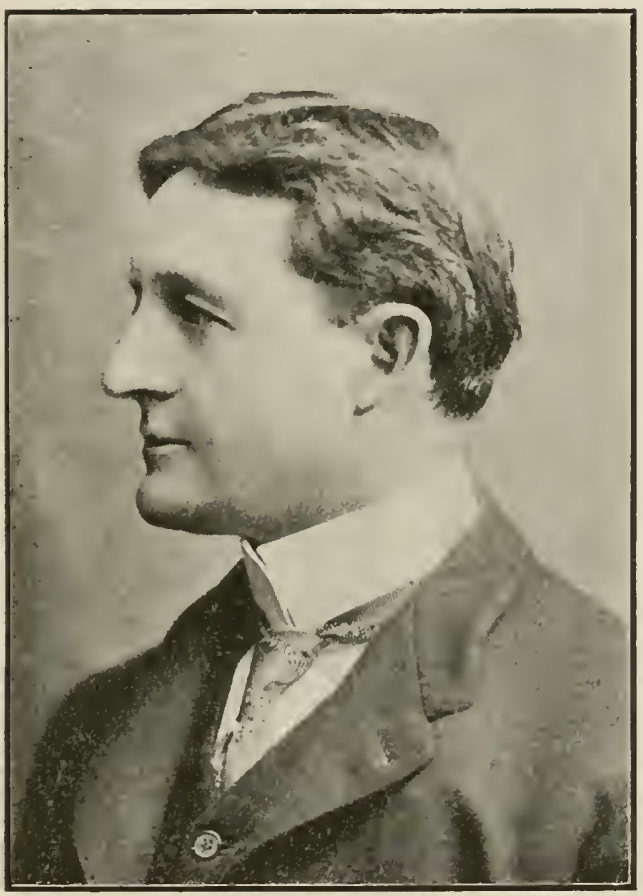

HON. ADAM BECK, LONDON. 



\section{THE DOCTOR'S PRACTICAL JOKE.}

The late Doctor Coleman, V.S., of Ottawa, generally had something in his stable that could go a little, and no man enjoyed a bit of sport better than he. I remember one win of the Doctor's over in Ogdensburg that netted him quite a few dollars, and if his friends did not have their share of the good thing it was not his fault, for no owner was ever more liberal in telling what he knew of his horses than he, but in this particular case, though the vet thought he had a good fighting chance, it was really an extraordinary chapter of accidents that gave him the victory.

It was a steeplechase for horses four times around the field inside of the half-mile track at the Burg, and out of the sixteen entries there were thirteen starters. Jack the Barber, then the property of the late Mr. Joe Grand, was one of the starters, so also was Blackbird, Viley, N. P., Barebones, Rathowen. Coleman had a big brown horse whose name I have forgotten for the time, and in the pool selling the night before the race and up to the hour of starting on the track he never brought more than a dollar in $\$ 25$ pools. At this odds his owner gathered in about a score or so. Early in the race Jack the Barber fell at the water jump. Viley went down at the same place. The second time around Barebones ran out, and on the fourth round, when the contestants should have swung out on to the track, they all, with the exception of the young fellow on Coleman's horse, kept on in the field. The big brown chap was a very tired horse, but he was fully sixty yards ahead on the home stretch before any of the others left the field, and though dying away at every jump, he lasted long enough to secure the verdict by a length, putting over five centuries in his owner's pocket by his lucky pool buying. 
I have often told how awfully fond poor Coleman was of playing practical jokes, and one of lis that I remember is good enough to bear repetition. While on a visit to Toronto he dropped in one morning about eleven o'clock at Kerby's saloon in the Romaine Buildings on King street. This was then quite a resort for theatrical people, and at different times my old friend had been introduced to members of the "profesh." One of those he had met was poor old Spackman, the leading man at the Royal Lyceum. On this particular morning there was a rehearsal of some kind of a melodrama in which the ballet dancers were a prominent.feature, and as it was only a few steps from the back door of the saloon, Kerby suggested that Coleman should go to the greenroom and see "Spack." Doc considered for a bit, and then, asking his friend to wait for him a moment, hurried out to a nearby tailor shop, almost immediately returning dressed in a long black clerical coat, with a white choker strictly churchy in its style and a clerical black felt hat. Even Kerby, who knew him so well, was staggered when he first saw him, so thoroughly did he look the part. Introducing himself as the Reverend Mr. Cole, a clerical who was anxious to learn a little about the theatre and theatrical people, that he might not do either an injustice in sermons he proposed to preach on the modern drama, he put himself under Kerby's charge and was taken to the theatre, brought round behind the curtain and there introdnced to "Spack." as a minister, anxious to see for himself the people he had heard so many naughty things about.

Poor Spack, who was the sonl of good nature, often told me of the nervous half hour he had of it. A couple of the girls, the high kickers of the ballet party, he said were particularly larky that morning, one of these having kicked his hat off while he was adjusting the ducal robes around his portly person, and the way the same little flirt was eyeing the parson he was satisfied she was only waiting a chance to dust his eyebrows for him. Hurriedly excusing himself for a moment, he called the girls 
into the green room and begged of them for his sake, and the reputation of the profession, not to kick too high, and above all not to wink at the parson. Full of fear the rehearsal progressed, and old Spack's heart rejoiced to hear the Reverend Mr. Cole express himself: "Mr. Spackman, I am gratified, Sir, greatly gratified, at what I am seeing now for the first time. 'The behavior of the whole party, Sir, is most polite, and while the young ladies, Sir, kick higher than I ever thought it possible to accomplish, yet, Sir, they do it so modestly, if I may be allowed the expression, that I cannot take exception to it. I am pleased to have been here."

These remarks fairly captured old Spack, who straightway introduced all the members of the company present to the "Rev." Mr. Cole, and begged his clerical friend to honor them all by allowing them to drink his health. The clergyman was willing to take something soft as an evidence of his good will, and a call-boy was immediately despatched to Kerby's for liquid refreshments. As soon as they were brought in Spack filled up the glasses, and in a clever little speech proposed the health of the " Rev. Mr. Cole, a gentleman whose broad, liberal views honored the profession he belonged to." The toast was heartily honored by all, and in reply the clerical guest spoke as follows:

"Ladies and gentlemen, I am delighted to be here and listen to all the sweet words you have served up to the parson, and if any of you folks ever strike Ottawa, I want you to call around and interview the grave and reverend Doc. Coleman. It won't be his fault if you don't all have a rousing good time of it. Spack, old boy, this is the first of April. You owe me one." As the Doc threw off the clerical sombrero and cut loose with an artistic bit of heel and toe work, poor old Spack fairly choked with laughter at the joke that had been played upon him, but earnestly begged the company to keep it quiet or the cost of setting it up for the boys would be his ruin. 
For Kerby's kindness in giving him the introduction Coleman promised to send him a pug dog as soon as he reached home, and true to his word he sent it. It came in a box three feet square, with innumerable holes bored in it, per express, $\$ 1.50$ charges. It was paid, and as Kerby's friends, a half dozen of whom were present, crowded around to see the well-bred dog, there, firmly wired in the centre of the box, was a china pug, weight about four pounds. Poor Coleman! It is hard to realize that a man so full of jollity and mirth and in the prime of life has run his race and weighed in for the last time. 


\section{THE GREAT STEEPLECHASER MILESIAN.}

There never was a timber-topper in Canada that could pile up the weight and stay with Milesian across four miles of stiff country.

I remember the day when over the McDougall farm, back of the mountain at Montreal, he landed the double event and carried confusion and dismay into the ranks of the westerners whose wigs lay thicker on the green than ever ornamented the sod of Donnybrook after its liveliest ruction. At three o'clock he started in the opening event, a light welter race, twenty-eight pounds added to weight for age, the distance, three miles across country. He was ridden by his owner, and though no one doubted his pluck, nobody had any faith in his riding ability, and certainly it was only an extra good horse that could have beaten the dozen good ones that started against him, driven, as Milesian was, from start to finish, his jockey riding with a. loose rein and unable to give him the slightest assistance. The country raced over was a very difficult one, over stone walls and stiff fences and the last quarter of a mile through swampy ground sufficient to stop any but the pluckiest of performers.

Milesian won by over three hundred yards. Thirty minutes after the winner of the light welter race had been announced from the judges' stand, the bell rang for the starters in the Open Steeplechase, distance four miles, and imagine the surprise of the crowd to see Mr. Bannatyne canter out on Milesian, though he had another rare good one, Duffy, entered in the race, a horse which the talent thought quite able to land the trick. Bannatyne, however, was deaf to all his friends' entreaties and expostulations; he was determined to try and beat the record by winning the double event, and he was equally determined to do the riding himself. As soon as Pool- 
seller Quimby opened the box, the westerners to a man plunged against Milesian, confident, as they expressed themselves, that no horse ever foaled could go the double journey, especially when handicapped by an indifferent rider, whereas the best cross-country jockeys in Canada were up on the other horses, some eleven in number, that started against him. If my memory serves me right, Milesian carried the top weight, 174 pounds, the nearest to him being Viley, with 162 pounds, and so on down to 135 pounds. At the drop of the flag Bannatyne rushed his horse to the front at the first obstacle, a "double" in the shape of a four-foot stone wall, into a lane and over another three foot and a half fence out of it, he had a clear length the best of his followers. When they passed from view behind the first belt of timber the gallant son of Mickey Free was striding along playing pathfinder by six clear lengths. When next they swung into view it was literally a case of Milesian first, the rest nowhere, and as he came on with untiring stride through the swampy home stretch two hundred yards in the lead one of the heartiest cheers I. ever heard at a race meeting welcomed the winner. It was the greatest feat ever performed by a steeplechaser this side or any other side of the water, and though Milesian did not prove a brilliant success in the stud, his record on the turf will forever keep his memory green in the minds of Canadian turfmen. 


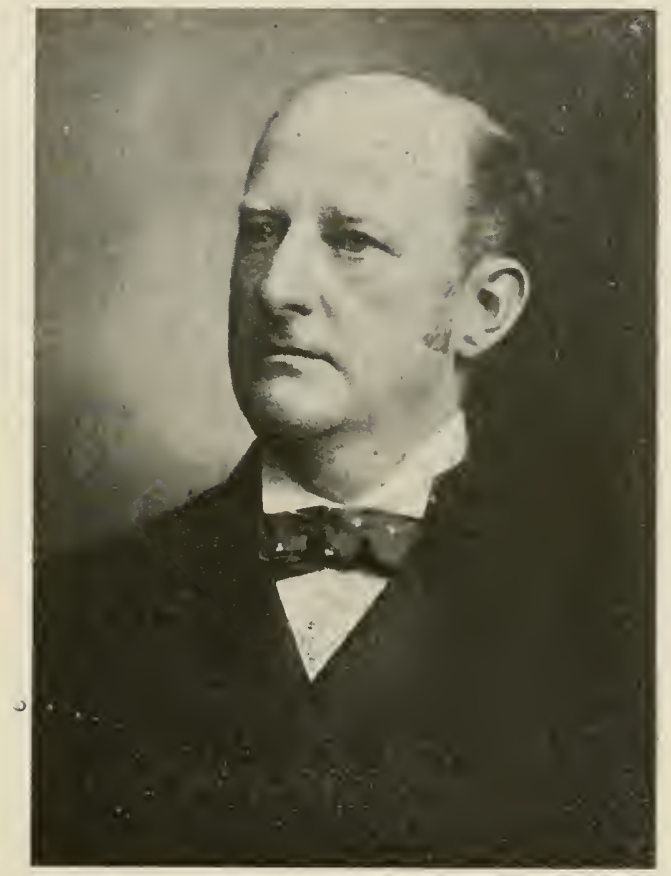

ROBERT DAVIES, OWNER OF THE FAMOUS THORNCLIFFE STOCK FARM. 



\section{A NOTABLE RACE AT LONDON.}

Sitting in the smoking room of the Tecumseh House, London, some time ago, in conversation with a wellknown western horseman, the talk wandered away back to the time when that still famous hostelry used to be crowded with outside turfmen. Thirty-five years ago there was a rare gathering present from far and near; conspicuous amongst them were Dr. Andrew Smith, Hon. C. I. Douglas, Major Peel, C. F. Elwes, Duncan (now Judge) MacMillan, Dr. Woodruff, J. E. Seagram, P. D. McKellar, T. Simpson, W. G. Henderson, John Davis, George Forbes, Charles Boyle, P. Farrell, etc. Many other good men were present who have since joined the silent majority, but a sufficient number of genuine sportsmen have been named to show how pleasant such gatherings must have been.

The old meetings at Newmarket track, London, were generally most enjoyable events, but that night as we talked of memorable bygone races, memory served up one noted contest on the old track that left much hard feeling and which created no small amount of scandal at the time. I allude to the race between King Tom and Archie Fisher's Sir Archibald. There was a lot of feeling on both sides, and the betting ran high. The cockneys pinned their faith to the first named, while the Toronto delegation, strong in numbers and purse, stuck to the game brown stallion, and thousands of dollars were wagered on the result.

Not only in the Tecumseh House over night, but on the track just prior to the race, the auctioneers, Quimby, Forbes and Page, were kept busy selling pools, and when the bell sounded for the horses to come out I have no doubt that there was as much money at stake as was ever before wagered on a race in Western Ontario. The race was a dash of a mile and a half and was a gallantly con- 
tested struggle throughout, but Archie's horse was trained to the hour and beat the "King" home by a clear length. So near and yet so far, however, fairly described the position of Sir Archibald's backer's. The race was so clearly won by Sir Archibald that it was impossible for the judges to juggle over it, but to the surprise of everybody, outside of a select few, they, while awarding the race to him, declared all pools and bets on the event off.

To say that the decision raised a row would be putting it altogether too mild. The crowd jeered and hooted, hissed and yelled, and at one time it looked exceedingly dangerous for the weak-backed men on the stand who had allowed themselves to be persuaded into doing a rank injustice. It was difficult to understand wliy they had so ruled. No complaint of foul riding had been made by the jockey on King Tom, and had such been done and proven, it would have demanded the punishment of the winner, but no such objection was raised; they awarded the race as the horses finished, yet without stating any reason, declared the bets off. Afterwards evidence was forthcoming which showed the reason why. A certain London merchant, now dead, had been wining rather freely over night, and being a strong King Tom man, backed his favorite for about $\$ 2,000$. The result of the race staggered him and he straightway got a friend or two together, besieged the judges' box, and induced them to declare the bets off. It was the only really unpleasant occurrence I can remember in connection with the oldtime meetings at Newmarket, but candor compels me to declare that it was one of the rankest decisions ever given on any race course, and in almost any other section of the country would have earned a jolly good mobbing for the judges guilty of such a trick. It is pleasant to remember that outside of the little ring influenced by the merchant alluded to, every other Londoner who had bet his money on King Tom, was ashamed of the manner in which he had been relieved of the necessity to pay his losses. 


\section{THE LADY WASHINGTON RACE AT CARLTON PARK.}

The Lady Washington race at Carlton Park a good many years ago was one of the most sensational events in the history of the Canadian turf. The race was mile and a quarter heats, and the contestants were War Cry, Moonstone, Lady Washington and Protection. In the pool box over night Lady Washington was a steady farorite with War Cry next in demand, Protection and Moonstone being rated about the same. About four thousand dollars was invested overnight, and on the day of the race no sooner did the pool-seller open out than fast and furious was the betting. For fully half an hour before the start two clerks were kept busy writing out tickets, and when the horses appeared at the starting post there was a heap of money in the box.

The first heat was stubbornly contested from start to finish. For the first half War Cry, Moonstone and Mi' Lady were head and head. War Cry then let out a link and though Moonstone and the little mare kept at it they were never again able to quite reach the leader, who won by a length from Moonstone, he the same distance in front of Lady Washington. The manner in which Captain Elwes' horse had won the heat sent a swarm of hedgers around the pool box who made desperate efforts to get out. One hundred, two, three and four hundred dollars were shouted for first choice, and every time War Cry was the first selection. Finding nobody would pick out a horse Quimby bunched the balance, and those who already had the cheap pools which were sold on War Cry overnight made themselves very secure by buying an occasional field against which the odds were about four to one.

In due course of time the horses were rung up for the second heat, and quite a crowd of prominent turfmen 
walked down to the quarter pole to witness the start. At the first attempt the flag went down to a capital send-off, all the horses being closely bunched. To the three-quarter pole they raced in close order, Moonstone on the lead. Rounding into the straight run home, War Cry moved up past Lady Washington, and laid with his head at the saddle girth of the leader. In this exact position they raced past the starting point, the three-quarter pole, and as they swept by Charley Boyle shouted to his boy on War Cry to pull back. The boy, evidently greatly surprised at the order, obeyed instructions and Moonstone beat him out by three-quarters of a length. No sooner did Boyle call to his boy to pull back than the late Mr. Bookless, who had been talking to him, remarked, "What do you mean, Charley, giving such an order as that?" Boyle's response was that his horse was sick and he wanted to save him all he could, to which Bookless responded that if he was running a sick horse he would like to get the race finished as quickly as possible. Boyle's error of judgment cost him the race.

No sooner was the heat announced to Moonstone than another rush took place to the pool stand. Those who had started in on Lady Washington and had swung round to War Cry, now jumped on to Moonstone, and several hundreds more were dumped into the box by the bewildered bettors. In the third heat War Cry went off with the lead, and as they passed the judges' stand, was leading Moonstone by a clear length, who in turn had about the same advantage over Lady Washington. At the halfmile Moonstone moved up to the leader, and in this order they raced the mile. As they levelled for home everybody was looking for an exciting finish between the two horses, when suddenly the little mare was seen to let out a link, join issue with the favorites and after a whipping finish she beat them out by half a length. War Cry second, a head in front of Moonstone.

The faces of the betting men were now a study. Those who had started in on the Lady, had, after the first heat, transferred their love to War Cry. When Moonstone 
placed the second heat to his credit the majority of them had followed him, and now here was their first sweetheart once more to the front and selling first choice in the pools for $\$ 100$ to $\$ 20$ over the field. At this rate a big business was done, one prominent sportsman of Toronto laying the odds fifteen times in succession. The fourth heat is easily described. The little mare outstayed the party, and from the drop of the flag was never headed. When the books were toted up it was found that $\$ 23,500 \mathrm{had}$ been wagered on that race alone.

NOW FOR THE SEQUEL.

Later, at Saratoga, the boy who rode Lady Washington in the race at Carlton Park, made the following statement how the race was won. It appears from what he stated that the boy rode seven pounds light, and the gang that followed the mare over here from the States so surrounded the boy when he dismounted that they managed unobserved to slip him the necessary seven pounds to weigh in correctly. Alexander Macnab, then the police magistrate of Toronto, was clerk of the scales, and neither he, nor any of the stewards, suspected anything wrong. It was a trick carefully and cleverly executed, if the boy's statement is true, and there is not a shadow of doubt that the slipping of the weights won the mare the race. Many a time the Lady Washington race is the subject of conversation when horsemen gather together, and it will be a long day before another such exciting contest is run. A well known and popular Q. C. won the best part of a thousand on the race, and many other fielders won big bank rolls on small investments. 


\section{A STORY ABOUT THE LATE CHARLES GATES.}

Away back in the olden days, when Charley Littlefield and Charles Gates were young and lively as kittens, the following circumstance is related to have happened:

Charles Gates was at Georgetown races with one or two runners, and during the meet he stumbled across an old peddler whose ostensible occupation was trading soap for ashes. His rig was an old springless cart, drawn by a small bay mare that looked as if she had gathered on her tail and mane about as many burrs as could be collected in one township. The harness was of free and easy style, pieced out with shoe laces and string. In a word, the general verdict of an outsider would have been that the whole institution, driver and all, had been struck by a hurricane and got badly broken up. The boss of the rig was a long, lean, lank, lantern-jawed down-easter, whose chief occupation at the hotel where he was stopping was drinking whiskey and emitting tobacco juice.

After loading himself with a tolerable cargo of whiskey he started talking horse with Charles Gates, leading with the assertion that "Ye never see no fast running horses now-a-days," he yarned about a mare he once owned that conld outrun anything ever foaled. Warming with his recollection of the old mare, he went on talking about a youngster out of her that he was driving, that was "all powerful smart on its feet and conld run mighty slick." The telling of the story evoked a hurricane of laughter, which seemed to rile the old 'un, and by this time the pendulistic motion of his body when he essayed to walk and the thickness of his speech proclaimed him to be two sheets in the wind and the third one fluttering. Nothing would satisfy him, however, but to stagger out to the barn and bring around the mare to be inspected by the company. 
After backing her out of her stall the old fellow straddled her, and with his long legs hanging almost to the ground and his upper works swinging backwards and forward, the combination was in the highest degree ludicrous. Marching around to the front, he walked the nag into the bar, and a second time sung her praises. The crowd, as before, jeered at the idea of her being able to run fast enough to keep herself warm and soon were jibing the old fellow at such a rate that, apparently grown reckless by their teasing, he offered to run his mare a quarter of a mile for a hundred dollars against any horse owned by any one of the company. Quick as a flash Charles Gates was on his feet, and though some objected to making a match with a man who was undoubtedly too drunk to know what he was doing, he himself insisted on "putting up the stuff." Charles Gates responded, and matched Yellow Rose against the ashgatherer's mare, the race to come off next afternoon. Before separating for the night, the ashgatherer, still stowing away the corn juice, emptied ont his pockets and increased the main stake to one hundred and seventy-five dollars a side.

Next afternoon a big crowd assembled at the track to see the fun, and though all the horsemen around the place laughed at the idea of there being any betting on such a one-sided match, a couple of strangers, both of them apparently on a spree, kept taking the 10 to 4 as if in a drunken frolic. Arrived at the track the old peddler unharnessed the mare amidst a running fire of chaff, and opening up a box under the seat of his wagon, he drew out a racing saddle and a suit of jockey clothes and, appealing to the crowd to know if there "weren't any youngsters around there that could ride a leetle bit," his invitation was accepted by a boy, a stranger to the crowd.

In a few minutes he was rigged in jockey costume and Gates' mare being also ready, they were led to the score. Without much delay the word was given. The first jump took the peddler's mare half a length to the good, and without an effort she beat Yellow Rose two lengths at 
the quarter. Never was a greater surprise. The laugh was on the other side with a vengeance, and the parting words of the old man to Charles Gates as he left the track: "You got a pretty smartish kind of mare, Mr. Gates, but she ain't quite good enough to tote around in a peddler's wagon," was anything but soothing to an irascible temper like that of Gates. Many were the dollars captured by the peddler and his associates, and for years afterwards the Georgetown track was a sore reminder with the veteran Canadian horseman. 


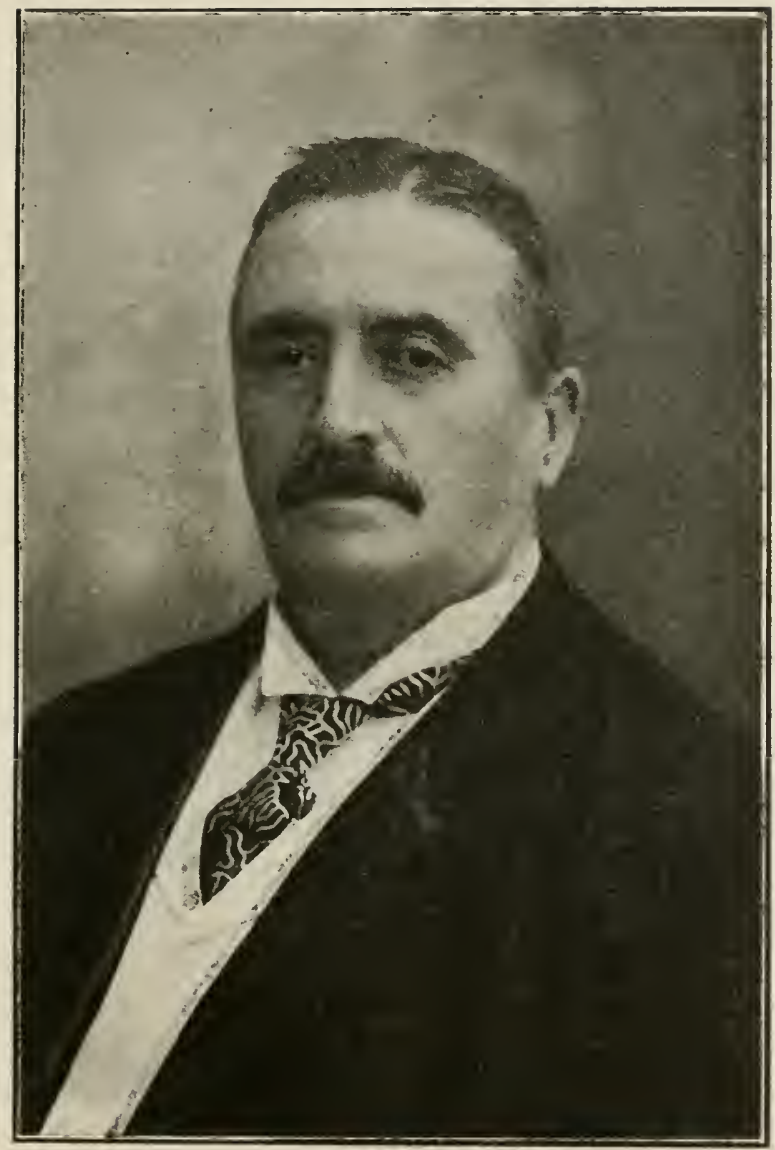

HON. WM. GIBSON, PRESIDENT HAMILTON JOCKEY CLUB. 



\section{THE RAVEN DROPPED BY THE WAY.}

It was away back early in the '70's that the story I am telling eventuated, and the three parties more particularly interested were the Hon. C. I. Douglas, Major Peel and Mr. Joe Grand. "Uncle" Joe has joined the majority, Douglas is domiciled in London, and Peel is living retired in Sussex. At the time I speak of these three were part owners in the black horse Raven, a very fair performer, but a brute of rather uncertain temperament. If he felt $O$. K. and nothing occurred to disturb his equanimity, it would take quite a flyer to beat him any distance up to two miles, but let anything happen to sour him and he could outsulk a Mexican mule.

The hor'se, however, had been running kindly for some little time, and it was determined to take him up to the Waterloo meeting and enter him in a dash of two miles that was advertised on their programme. At that time there were two or three good long-distance performers around, and the three gentlemen mentioned, confident that Raven had showed them a trial good enough to take them all into camp, determined to back him well and scoop the box.

The night before the day of the race the pool-seller started in, and a good bit of business was done on the two-mile dash, with the black horse sometimes a second and at other times a third choice. Major Peel was doing the business for the party, and when the box was closed for the night the trio had secured about every pool on Raven and stood to win quite a large pot of money.

Next day at the track, finding their horse in good form, they again sailed in, and so persistently did they stick to their representative that by the sheer force of their money they finally forced him to the front, and when the 
bell called up the starters in the race Raven was selling favorite. There was not much time lost in getting them away, and when the flag went down Harry Brown sent Raven to the front and he carried his field along in merry fashion. Uncle Joe was standing in the field near the judges' stand and was so delighted with the way his favorite was running that, following his usual custom when in a happy frame of mind, he commenced to speak out his ideas about the race.

As the horses went by the judges' stand at the end of the first half mile Raven had a clear lead of two lengths and was running well within himself. I was standing at Uncle Joe's elbow as they swept by, and I shall never forget the cheery ring of his voice as he shouted, "they'll never catch him. No, sir'ee, they may as well chase their own shadow as that black rascal to-day. Look at him boys-isn't he a race horse? Who wants to bet twenty against a hundred that he'll be headed in the race? I'm just looking for some man to open his mouth that way. Come along, old boy." And as they went by the judges' stand the second time, with the black fellow three lengths on the lead, Uncle Joe kept on talking.

"Why they can't stretch his neck. They're not in his class, my hearties. He's a race horse, you can bet on that. I say, Douglas, what crabs those horses are alongside of him. Why, Peel, it's guineas to peanuts. Just look at him, watch him there, will ye, just see him. Holy Jupiter, he's down." And sure enough, swinging the upper turn to the finish of the third half mile, the leader sulked a little, and Brown foolishly gave him a sharp cut with his whip. Quick as a flash he swerved away from the rail, and as he did so his feet went from under him and he slid half way across the track. Comment upon the change that came over the little circle $I$ had been standing alongside of is scarcely necessary. Peel commenced to count his pile to see if he had enough to carry him home. Douglas started to chew straws and figure up his position, while Uncle Joe declared it was his usual luck. "Another sure thing gone to blazes." I forget now the name 
of the horse that won it, but I remember very well that about the only parties who benefited by his victory were the hayseeds who bought him because he was selling cheap. And that night amongst that brotherhood lager beer flowed right merrily and they whooped it up from one end to t'other of little Yarmany. 


\section{PAST AND PRESENT PROVINCE-BRED HORSES COMPARED.}

To hear many of the present lot of Canadian turfmen talk you'd think the Camadian horses of twenty-five and thirty year's ago were all lobster's that couldn't win a cheap selling race in these days. Of conrse those who talk that way don't know anything about it, because the majority of them were either wearing bib and tucker or about sprouting into short pants, but they heard somebody no wiser than themselves say so and, parrot-like, they repeat the story.

I can mention a few of the old-time duffers, as they would call them, that were quite good enough to win a full share of the money in present-day company. In those days the tracks were many seconds slower than they now are and the jockeys rere searcely up to the present standard. Another thing, horses had to be trained in a different fashion, owing to the fact that racing was a much more severe game. There were no five-furlong dashes then; an occasional three-quarters; plenty of mile heats, two in three and three in five, and two-mile heats, and this sort of programme demanded that a horse should have condition as well as speed. No matter how much of the latter he possessed, if he didn't have the former, the other wouldn't win for him.

I have seen more than one race in Canada when it took seven heats of one mile each to decide the winner. There was no rule then about a horse going to the stable if he didn't win a heat in two or three, and it was a stubborn fight to a finish and the survival of the fittest. I wonder where the majority of our present-day sprinters would be in one of those old-time gruelling struggles? The chances are that one such race would knock them out for 
a whole season. Memory serves up a few old-time provincials that would be quite worthy company for the best of those raised at the present time.

Princess by Princeton-Roxaline, was an extra good mare as a three-year-old. She campaigned all through the States and won some splendid races. She scored at Saratog'a, Louisville, Memphis, Dallas, Tex., Gainsville, Tex., and New Orleans, La. She kept on winning at four, five and six years of age, and five-eighths in 1.02 and miles in 1.44 with weight up over the tracks of those days was quite up to the best efforts of present-day provincials. Brait, a full brother of hers, was another good horse. As a three-year-old he won at two miles, and the next year he beat big' fields of good horses, both at Saratoga and Brooklyn, N.Y. I saw him race at the Springs where he defeated an even dozen, carrying the top weight, 112 pounds, and he won in a canter by six lengths, three-quarter's in 1.16 over a slow track. The Brooklyn race was seven-eighths, and here again he beat a strong field in a gallop by three lengths in 1.291/2. The following year, as a five-year-old, with 120 pounds up, he ran three-quarters in 1.16, defeating such good ones as Barnum, 117 pounds ; Castilian, 115; Leonora, 113, and several others.

At Jerome Park he won at a mile in 1.45, beating a strong field in a gallop. As a six-year-old he won nine races. His first victory was at Jerome Park, where he defeated a good field of high-class horses in such commanding style that Billy Lakeland ran him up from his entered price of $\$ 1,200$ to $\$ 2,800$, and secured him. $\mathrm{He}$ next won a high weight handicap at Coney Island, carrying 135 pounds, and running the mile on turf in 1.45 . How many Canadian-bred hor'ses to-day could repeat the trick on a similar course? This is one more nut for the modern critics to crack. At Monmouth Park he ran seven-eighths in 1.28, beating such flyers as Swift, Flageolette, Benedictine, etc. A little later, at Brooklyn, he carried 124 pounds, the top weight, and beat a field of nine, including such stars as Tea Tray, Long Dance, Ban 
Cloche, Wilfred, Tattler, Prose, Rowland, etc., running the mile in 1.44, winning easily by two lengths. At Washington he also galloped away from a big field of good ones, again carrying top weight, and late in the autumn, down in Georgia, he won four races out of five starts. When seven years old he won nine races, running all over the United States, over all sorts of tracks and able to win in good company. The following year, when nine years old, he also earned brackets. In fact, he was a high-class race horse, and any Canadian owner who has as good a one to-day might smile serenely, satisfied with his chances at Woodbine.

Disturbance, Jack Vandal, Jack on the Green, Nettie, Terror and many others could be named, all of whom would prove worthy the company of present-day province breds. 


\section{A FEW OLD-TIME SPORTSMEN.}

Rumaging around the pigeon holes of an old-time desk in my snuggery I ran across an ancient race bill that brought recollections both pleasant and sorrowful. Pleasant, as a reminiscence of a jolly night, brimful of enjoyment within the bounds of reason and made memorable in one's mind by the many good fellows that were present; sorrow, tinged through the recollection because so many that on that night were full of life, hope and ambition, are to-day sleeping the long sleep that knows no awakening.

Let us hope that they have gained by the change. I take no stock in the frenzied doctrine that conjures up visions of brimstone lakes and unutterable torments as the future state of those who in this world live not up to strict puritanical notions. The man who tries to act fairly and lives a decent life, even though he does toy in moderation with the wine cup when it is red and believes in tasting a little of life's joys and pleasures as he passes through this world, has, in my judgment, as fair a fighting chance in the hereafter as the sanctimonious AshWednesday-faced chap who goes to church twice every Sunday, and then on week days seeks to impress on you a sense of his superior godliness. I admire the genuine Christian who never obtrudes his goodness, but that other professional whiner I take no stock in, and I am willing he should reap all the good to be gained by such an earthly preparation.

I've wandered off the track, though, and now to the pleasanter thoughts that recollections of the many good qualities of the absent ones bring up. There was Jack Munro, not much given to making friends, but true as steel and all geniality to those he liked. A man of wide worldly experience, possessing ample means to live in 
comfort, yet one whose venturesome spirit led him to take the overland journey to California, one of the Argonauts of '49. Many a queer, out-of-the-way corner of the world he explored, and when tired of his roaming, back he came to the old home. He was one of the brightest scholars of his day at old Upper Canada College; was in the same class with the present Edward Blake, and the records prove that he outranked him in class standing. Jack, however, hated office work, and was content to play the role of citizen at large. He was passionately fond of the thoroughbred, and for many a year was a constant visitor at all the running meetings lield in the country. He was a rare good sort, and his death was deeply regretted by all who knew him.

Another of the old guard was Joln Hendrie, big of frame and equally big of heart, a man who rode at fourteen stone and went straight as the crow flies. I think I can see his smiling face now; a complexion like a girl in her teens and a voice, when it sounded in the hunting field, like the notes of a silver bugle; a man game as a pebble and everyone who knew him was his friend. What more would you ask as a credential in his favor? He also is but a memory. A seven-foot mound on the heiglits overlooking Burlington Bay marks his last earthly resting place.

Major Peel, representative of a good old English family, a clever, popular fellow, fond of all sorts of sport, but one of the unluckiest chaps that ever tossed a coin or bet on the issue of a race. I once heard him declare that if he wagered six and six made twelve, the other fellow would be able to prove it was thirteen. He dabbled a little in the racing game as an owner, having, along with the Hon. C. I. Douglas, brought Bill Bruce to this country. A very speedy horse, but an unlucky one. He was brought over especially to defeat Kelso, then owned by Archie Fisher and carrying everything before him. They met at Guelph, and Bruce quit so badly in the race that it was apparent to everybody that he was "all off." A few hours afterwards it was rumored that he had been 


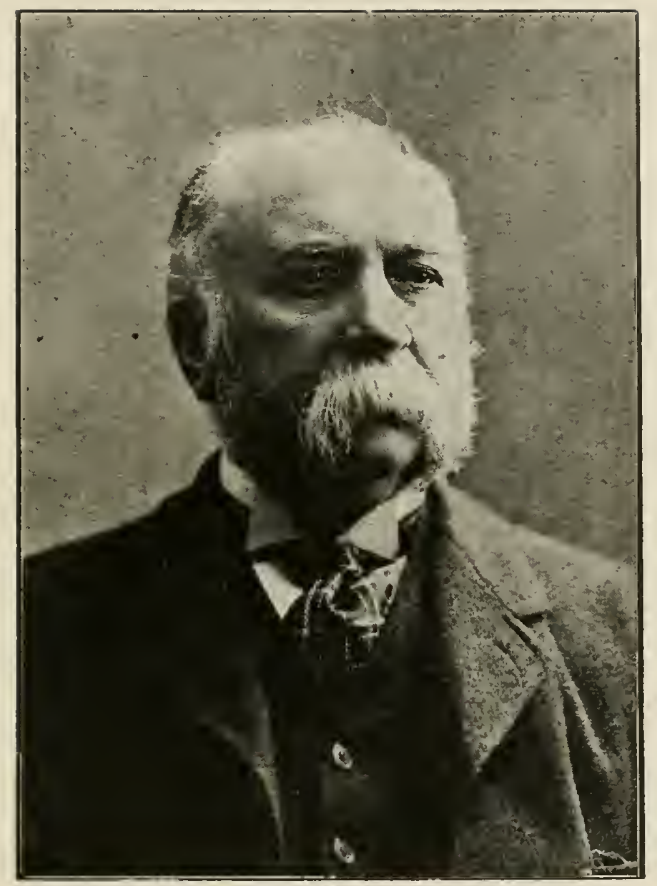

DR. ANDREW SMITH, CHAIRMAN EX. COM. ONTARIO JOCKEY CLUB. 

"got at," and from information afterwards gained it appeared that his muzzle had been removed and the horse had filled himself with hay and oats. What added color to the story was that a boy who had looked after him cleared out immediately after the race. The affair so disgusted Peel and Douglas that they at once sold the horse to the late John Forbes. In the hands of Charley Boyle he proved himself a game good performer, but he soon went lame, and though the patching process was practiced on him for two or three years, he could not stand the pressure, though his owner lost thousands of dollars backing him. The "Major," after taking a "fly" as the lessee of a theatre, a stock broker, a gentleman farmer and a travelling passenger agent for a railway, finally wandered back to England, and is now rusticating in the neighborhood of his old home.

How many of you are there who remember Clarence Moberly? At one time chief engineer of the Northern Railway and a prince of good fellows. Rather undersized in height, but a compact, wiry built one, always in the pink of condition, with a face clean-cut as a cameo portrait, ever garbed neat as a new pin from the soles of his boots to the crown of his head. There was nothing in the world he was so fond of as racing, and there were but few meetings but what he attended. He was a liberal backer of his own opinion, and once set on a horse he would put his money down with a free hand and his most intimate friends conld not get him to hedge a dollar, no matter how bilious his chance appeared.

I remember one time at Carlton Park he was in the "box" over fifteen hundred dollar's on War Cry in a memorable mile and a quarter heat race, and though the writer urged him to "hedge" after the second heat proved his horse was amiss, he refused to shift, and next morning it cost him over $\$ 1,600$ to settle. Though by no means burdened with wealth, he came up to the settling desk with his usual smiling face, and after paying the pool-seller he handed the Club Secretary $\$ 25$, the amount he had some days previously subscribed to the racing 
fund. Though that official declined to accept it, considering the bad luck of the donor, he insisted on it being accepted. Some of his Barrie friends once induced him to buy a trotter and give him to Pat Carney to train. He paid $\$ 300$ for the promising proposition, and within three months he deckared the trainer sent him bills for harness, boots, blankets, shoeing, medicine and other fixings for more money than the nag cost. He concluded as he didn't own the railroad he was in, or a bank on the side, the luxury was too costly, and he offered the trainer to toss a coin with him whether he kept the horse and paid the bills or t'other side on. Pat declined the risk. Moberly then settled and gave the horse away. His sudden disappearance is to this day an unsolved mystery. It is said that he was on the ill-fated train that disappeared in the terrible Johnstown disaster. It was known he intended travelling in that direction on that particular day, but whether he was one of the scores that perished in that awful flood, has never been revealed, but whatever his fate, no truer friend, no higher principled gentleman ever loved the noble sport.

Hon. C. I. Douglas, of Oak Ridges, was then one of the "regulars," and also one of the best-known horsemen in Ontario. He bought two hundred acres of land up on the Ridges, a little east of Yonge street, and as he afterwards declared, when a strong east wind blew it would carry twenty acres of his property across the road onto his neighbor's farm, but the same always came back to him when the same strong wind came from the west. He was a warm friend of Anson G. P. Dodge, the son of the New York millionaire, who bought a big estate up at Keswick on Lake Simcoe and spent a healp of money on it. Being ambitious to gain a position in the country he took the oath of allegiance and decided to spend any part of $\$ 50,000$ to get elected a Member of the House of Commons. He spent the money and got there. Being anxious to help his friend Dodge, Douglas undertook to canvass his immediate neighborhood and put in a few good words for the Conservative candidate. His opponent was 
a local man, a well-known farmer, and as the constituency had from its earliest history been red-hot Reform, the farmer's election was considered certain. Douglas' nearest neighbor was a canny Scotchman like himself, and when the former called at his house and asked him how he was going to vote, "Mac" replied he "hadna quite made up his mind." "Dodge was a guid liberal man," lie'd heard, "but then, ye ken, t'other man was a decent chap also." Douglas warmed up in favor of his friend Dodge, spoke of his wealth, his great ability and the enormous interest he had in the country and rather belittled the calibre of the farmer who was running against him. "Mac" listened quietly to the outburst, then sturdily replied:

"Nae doubt, Mr. Douglas, ye ken what ye are saying, but all the same I'll mae rote for him. I'll gang t'other way."

Douglas, who up to this moment thought he liad made a convert, broke loose with: "Mac, you are a damn'd fool. You don't know enough to bore a hole in the snow,' and the irate canvasser' went straight home, chucked his book into the fire and decided he wasn't cut out for a political canvasser. Mr. Douglas finally tired of his northern sandbank and returned to England. His headquarters are Liverpool and he occasionally makes a flying trip to this country. 


\section{THREE-MILE HEATS ON THE DON RACE COURSE IN 1846.}

Once more I travel back to the days of the old timers. To the days when Messrs. Boulton, Romaine, Gates, Littlefield and others were in the bloom and prime of life and never so happy as when making a match or watching a race. The year $18 \pm 6$ was a red-hot one in this province. Mr. George Parish, then of Ogdensburg, but later of Viemna, and while there a prime favorite at the Court of the Emperor of Austria, came over to Canada with his stable of thoroughbreds, prepared to give battle to all who chose to challenge him or accept his offers. Mr. Parish was deservedly popular with all who had the pleasure of his acquaintance, and whether on the quarter stretch or in the salons of fashion, he was alike the courtly gentleman and accomplished scholar. During his visit to Toronto, at the time I allude to, he was the guest of the late Chief Justice Robinson, father of the popular Joln Beverly Robinson, afterwards Lieutenant-Governor of Ontario; who was himself an enthusiastic admirer and a warm supporter of all legitimate sports.

One night, over their wine, Mr. Parish, who was never so happy as when chatting apropos race horses and racing, offered to match his horse Americus against any horse in Canada, three mile heats, for one thousand dollars a side. The offer was no sooner made than it was accepted by Mr. C. E. Romaine, who named Gosport, a bay stallion, lately brought to Canada by Charley Gates. The race was to be run on the Don track in four weeks, and straightway Romaine purchased Gosport from Gates and entrusted his training to Sage Armstrong, who a few years later became well known as a trotting horse owner and driver, both in Canada and the United States. 
Mr. Parish's horses were all under the skilful handling of Shaw, who for many years conducted a noted establishment on Long Island immediately opposite the famous Hiram Woodruff's place. The morning after the match was made a legal gentleman waited upon $\mathrm{Mr}$. Romaine with the "articles," and both principals' names were attached to them. When it became known that such a match was made a lively interest was roused and outside specutation commenced. The betting was pretty even up to within a day or two of the race, at which time it leaked out that Americus had been highly tried and found to answer all expectations, then Parish stock went booming and soon $\$ 100$ to $\$ 75$ was freely offered and as freely accepted.

The weather for a week before the race was above reproach and on the eventful day it was as if ordered for the occasion. For two hours before a steady stream of Yorkites were pouring in the direction of the Don, and when the saddling bell sounded, fully five thousand people were on the course. The chief notables of the province were on hand, and many a charming Miss that day sported the colors of her favorite, and so numerous were the boxes of gloves wagered on the event that Kay's stock of kids was exhansted within twenty-four hours after the judges' decision.

The race itself was memorable for the desperate nature of the struggle throughout. In neither heat from the drop of the flag to the finish was there more than a couple of lengths between them. Entering upon the last half mile of the first heat Americus was leading by two lengths. Gosport here accepted the challenge, and after a terrific struggle round to the home stretch, succeeded in showing his head in front. Down the straight run it was a fierce struggle and the excitement of the multitude was at fever heat. Fifty yards from home Gosport made a supreme effort and gained the verdict by a scant half length. The second heat was almost a repetition of the first. Americus piloted the way for two miles and threequarters, when Lewis on Gosport, made his move and 
again a cut and come struggle resulted. Half way down the stretch Gosport got his head in front and responding gallantly to his rider's call, came away and won a magnificent race by a clear length, landing a big pot for Mr. Romaine and his friends. 


\section{PAST AND PRESENT RACING.}

There are some new-fledged turfmen who pretend to believe that racing in Canada thirty or forty years ago was of no account. True, the tracks then were not as fast as now, neither were their furnishings as liberal, nor the purses as large in amount as those offered at the present day, but the charge for admission was small and the public then, as now, were liberal in their patronage. Prominent men from distant sections of the country used to foregather and there was more friendly intercourse and social enjoyment at those early meetings than at the present time. In a word, there was more pleasure and less business, more keen enjoyment of the racing through enthusiasm for the sport than for the sake of the money that could be squeezed out of it. Yet when memory travels back to the date alluded to, I can picture many a gallant contest, recollections of which stir the blood even now.

In 1873 Barrie course was in its glory and a goodly number of dollars were offered in premiums. Their July meeting that year was a memorable one, it being the initiatory year of the Canadian Derby, which was won by Dr. Smith's War Cry, who landed at Barrie after a most eventful trip from New York. It appears that after the Doctor bought him, he selected a groom to fetch the Derby candidate on to Canada, giving him instructions to follow immediately. The Doctor arrived home, waited day after day, but no horse came to hand, and though he kept the wires busy with his messages of enquiry, nothing could be ascertained from Gotham, except that man and horse had left there at the time ordered. Finally the missing pair were found at Albany, it turning out that the groom had become crazy on the journey and had taken the horse out of the car at Albany, and had left him in a livery stable there. When reclaimed by the 
Doctor he had been standing in a narrow stall for nearly a week, receiving no further exercise than two trips daily to the trough at the stable pump.

He only arrived at Barrie the morning of the race, and when stripped for the contest looked in no shape to win it; but the quality of the company was such that they couldn't make the pace fast enough to make him quit, and despite his being "all off," he won the Derby by a length in the slow time of $2.471 / 2$, the distance, one mile and a half. War Cry afterwards won many good races on the Canadian turf, but as a sire of speed was not a success.

The Queen's Plate, at the same meeting, was a capital race, there being eight candidates for the Blue Ribbon, and several of them having a string of staunch supporters back of them. If I remember aright, honors in the pool box were about even between Mignonette, Norlander, Goldfinch and Emily, and lots of money depended on the issue. The race was a slow run one, but it was a close game throughout, the verdict being secured by Mr. Pringle's Mignonette, the others finishing as named above. No sooner was the winner's name announced than some miserable kicker started a report that the mare was a foreign bred, and therefore not eligible for the Plate. So persistently was this story repeated that quite a number of people began to believe it, and in a few hours it had so increased by the telling that some were ready to declare that they knew all about it, that the filly had been brought over from the States when a yearling, and that indisputable evidence could be secured at Cobourg to prove it. Mr. Pringle, the owner of Mignonette, took just the right course to put a summary stop to such scandal. He expressed his willingness to make oath to the eligibilty of his filly, and at the same time wager from a hundred to a thousand dollars that no man could prove one word of the story about the filly true. This, though it did not altogether shut the mouths of the squealers, was satisfactory to everybody worth satisfying. 


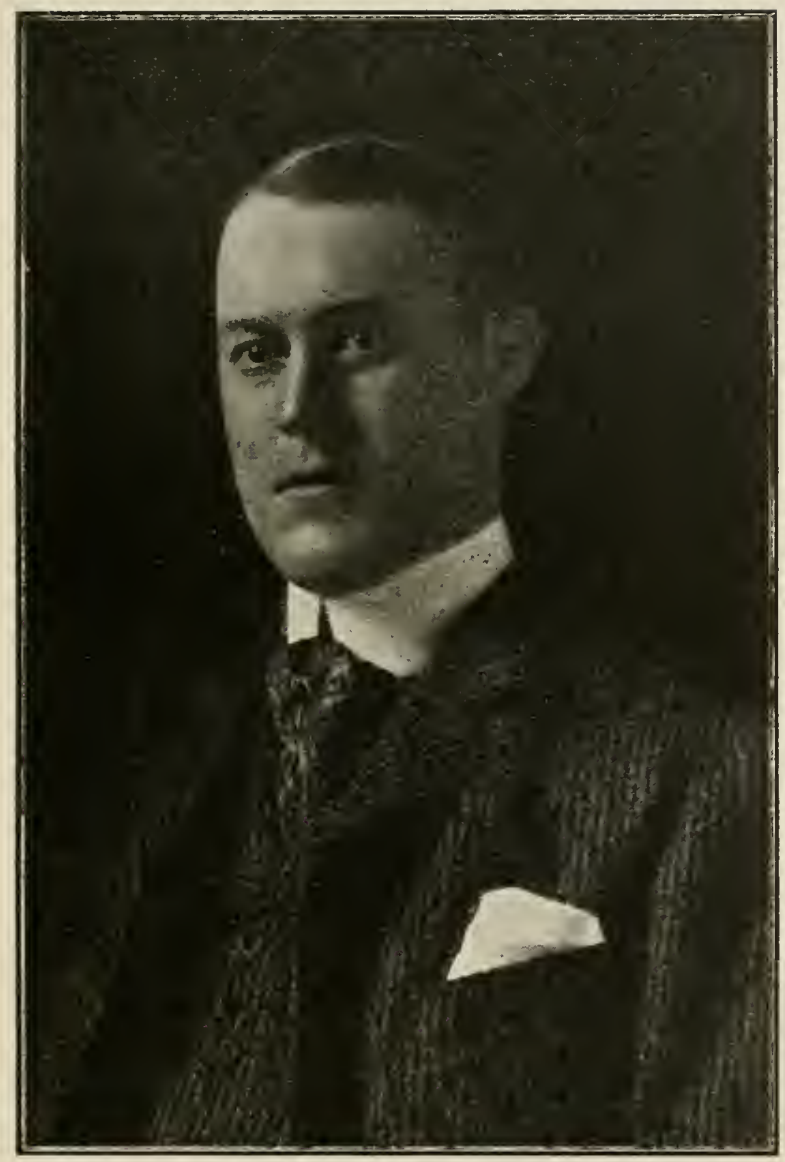

GEO. M. HENDRIE, PRESIDENT WINDSOR RACING ASSOCIATION. 

On the day following that on which the Plate was run there was a very exciting hurdle race between Mitchell, Jack the Barber and Edenton, the latter, one of the worst mannered brutes that ever had a saddle on his back. In the hurdle race alluded to Mitchell was a red-hot favorite. His victory of the previous day over the same company made it, with the majority of the bettors, a foregone conclusion, but there were a few who paid a little more attention to the matter of weights, and remembering that the favorite had a heap of lead up, cast their affection upon Jack the Barber, another mean tempered one. Jack at that time was owned by "Uncle" Joe Grand (green be his memory), and the writer of these "Recollections" remembers well his expressive remark just prior to the start and after a few ducats had been posted on his chances as a mutual "spec": "If Jack don't sulk, he'll break Mitchell's heart the last half mile," and the prophesy proved true.

The race for a mile and a half was a neck and neck struggle, each horse lifting together at the jumps. But once squared on the stretch for the home run, weight, that great leveller, commenced to tell, and, though Quebec's representative fought a gallant fight, responding nobly to every call of his jockey, it was not to be, and Ontario's champion gained first honors by a length. Great was the shout that went up from the throats of the people, and many were the hearty congratulations extended to "Uncle" Joe. Methinks I can see him now, his jolly face full of smiles and his cheery voice sounding clear as a bell as he cracked his jokes and called upon his friends to join him in a bumper of sparkling Moselle. Those were pleasant days, let the croakers say what they will. Many a good man and true went the rounds and enjoyed the fun and though charges of fraud were frequent, yet I believe that about nine times out of ten the charges could not be sustained. It will be many a day before a more enthusiastic lot of good fellows will follow the fortunes of the Canadian turf. 


\section{ELEVEN-HEAT RUNNING RACE.}

Do not favor me with a smile of incredulity, for I experienced that once before when, with a party of friends seated around a table in the Windsor Hotel, Montreal, I made the statement that I had once witnessed an eleven-heat running race in Canada.

Three men's hands went immediately to their trouser pockets to hand me out the historic penny for proposing to tell such a whopper. I refused the coin, but wagered them a cold bottle with shell oysters, as an appetizer, if I could not prove the truthfulness of my declaration. Each one accepted the bet, and it cost them $\$ 25$ to settle.

For the benefit of other doubting Thomases, I will give the particulars here. It was up at Elmira village, in Waterloo county, in the year of grace 1880, that I saw the race in question. It was half-mile heats, three in five, for a purse of $\$ 100$, and the complete summary follows:

Paladin. . ..........5 $5311613533^{*} 1$

Mischief...........2 $6335344411^{*} 3$

John Logan..........6 62615214232

King Harper.........44 4553441222644

Priscilla............. 30000265 dr.

Ella Walker..........7440026 4 dr.

Oscar. ............8 $8044 \mathrm{dr}$.

Lazy Harry......... $1520 \mathrm{dr}$.

Time not reported.

I am inclined to think that the above is a record. I have witnessed many long-drawn out contests, but not one of them equalled this, and the little German village of Elmira can lay claim to having had the longest drawnout running race in the history of the turf decided on their track. 


\section{A "MERRY DAY" TIP.}

Whew! but those Montrealers had it served up to them hot and strong that winter. Certain of the wise citizens of the Eastern metropolis became acquainted the summer before at the Bel Air meeting with some horse owners whose occupation is more of touting than training. After that meeting closed in August the tipsters kept the wires busy sending on "sure" things to their Montreal clients.

When the New Orleans meeting started, then the touting game commenced in earnest, and considering the conditions on which the touts were doing business, viz., put up nothing and draw half the winnings, it is not surprising they kept the wires warm with their information. One of the most persistently touted horses, both that fall and all winter, had been Dave S. A syndicate had been formed and the final wind-up of investments on that in-and-outer was a total loss of over $\$ 2,500$. Hope again told its flattering tale with others, but the blanks so far outnumbered the prizes that outsiders wondered the northerners did not shut down on the southern tipsters.

Just about the time they were getting tired of investing more money in lobsters they were favored with a brand new, double-dyed-in-the-wool, thirty-seven-inchesto-the-yard article that was guaranteed to be more sure than taxes. Aurora never gilded the sky with more brilliant promise than the New Orleans confederacy pictured the absolute certainty of their latest triple-riveted, bessemer steel, armor-plated, double-turreted certainty. No anarchist leader was ever sworn to more inviolable secrecy than the Montreal chosen ones-these, about six in number-who were warned to get ready for the most sanguinary slaughter of the whole winter season. A telegraph code, as secret as the grave, was in use, and day by day the Montrealers waited for the fateful news that 
was to hand over to them the pool-room keepers of the East, to be shorn as close as any sheep that ever left the shearer's hands.

The chosen six were obligated to bet a large amount and cut the winnings in half, sharing with the New Orleans party, and large though the sum was that was to be invested, it was on hand ready for instant use as soon as the signal came to cut loose. That signal came on a Thursday morning to be ready to play a certain horse in the sixth race on Friday. With the silent alacrity of the historic Arab of the desert, the chosen six disappeared from their usual haunts; it was as if a great hole had suddenly opened up and they had dropped in. With the subtle instinct of a Hawkshaw one or two of them started from suburban stations fearful that the keen scent of some suspicious one would unearth their little game. Friday noon saw them ready primed for their deadly work at Albany, New York and Buffalo, one old reliable being left in Montreal to attend to the local shop. Whether that old reliable leaked, or whether one of the six conspirators, before leaving whispered the secret to Tom and he had bleated to Jack and the latter dropped it to Dick, deponent knoweth not, but sure it was that on Friday morning mysterious hints were dropped by wise men and other cunning ones passed it round to their chosen chums, and in the local pool room there was a hum of suppressed excitement all afternoon.

At last when the odds went up on the sixth race, one would have thought a bunch of Texan steers had broken loose, the way they jumped to the front, fearful that something might happen to prevent their hands getting into the jam pot. Men who usually wager a couple of dollars were betting twenties, and the fellows who occasionally loosen up and gamble five each way, were throwing in fifties and hundreds and every mother's son of them was down on Merry Day. So here was the longprepared, anxiously-expected slick one revealed at last. Curly Brown's skilful hands were said to have put the last finishing bloom on the peach. The horse had been 
trained to the hour, and was to be delivered cherry ripe at the post. The local pool rooms never gave more than 4 to 1 and at this price they were peppered so vigorously that they soon cut to 2 to 1 and finally 8 to 5 , and even at these shrunken odds quite a pile of money was bet. When "they're off" sounded through the room there was a stillness almost solemn in its intensity. It was so dense for a few seconds that one felt he could cut it into pieces, and when the caller-off said: "Percita first, Merry Day second," the wise men were shaking hands with themselves, and when the next call came that Merry Day was second in the stretch, only a neck behind the leader, there was an audible chuckle all over the room, which suddenly changed to a sort of frozen smile on the face when the words rang out from the operator: "Command wins by a head, Merry Day second." Another sure thing gone wrong. 


\section{NE'TTIE'S TRIUMPH AT LONDON.}

The day that Nettie downed Belle Mahone on the Newmarket race course, London, I was there, and the boys' wigs lay thicker on the green than on the day after the big fair at Ballinafad. Who got scorched? Why, all the knowing ones, of course. In a word, a few plotters had it worked down to a fine point. Quimby, the pool-seller, with a couple of able assistants, had dropped Belle Mahone in quietly from Michigan, and so sure was the trick that the cunning ones just went around begging the unsophisticated to accept long odds on the result. In the reading room of the Tecumseh House over night a large gathering of turfites had surrounded the pool seller. Representatives from many sections of the province were on hand: Hon. C. I. Douglas, Major Peel, Jack Munro, C. E. Romaine, Joseph Grand, Mr. Cash, Mr. Bookless and a strong delegation from Hamilton, with many others that memory fails to chronicle just at the moment.

From the opening of the box at 8 p.m., to the drop of its lid at half-past ten, a lively business was done, and from first to last Belle Mahone was a red-hot favorite. The average run of the tickets was Belle, $\$ 30$ to $\$ 40$; Mohawk, $\$ 15$ to $\$ 20$; Nettie, $\$ 3$ to $\$ 5$, and at those low figures the province-bred was slow of sale as ice cream on a January morn. "Who'll take the old slave at three dollars?" was Quimby's incessant appeal to his customers, and it was mighty hard work to get anybody to respond. "Yes, Nettie may win if Belle and Mohawk both fall down," said a prominent horseman to the writer, who had expressed a high opinion of the superb condition in which Dick Leary had brought the old mare. Such was the opinion of everybody who had a thought to express about the race. Belle Mahone had been campaigning with great success through the Western States 
and Mohawk was just then thought by his owner, John Forbes, to be good enough to rum against any man's horse. Old Nettie was looked upon as out of the count, a good mare though she had proved herself in a score of hard fought fights; she was considered outclassed and the most enthusiastic backer of the White stable couldn't pluck up nerve enough to do more than take one or at most a couple of the three-dollar snaps. The day of the race was as fine as one could wish for, and a large crowd of people gathered to witness the sport. Prior to the start of the big race, which was a dash of two miles, poolselling was continued with great vim, the Quimby combination sticking to Belle and the Forbes contingent piling it upon Mohawk.

As the horses cantered past the judges' stand in a preliminary pipe opener, neither of the two favorites filled the eye equal to the daughter of Kennet. Leary had eased her up for a week or so after her early summer campaign, and certainly she looked and acted fit to run for a man's life. With the sheen of satin on her coat and an eye bright as a hawk, many a one familiar with the gameness of the pride of Halton regretted they had not taken a few of the cheap ones that had all along been going a-begging. The veteran Leary was in the saddle, and his old head was worth seven pounds any day against boys, especially in a two-mile dash. There was very little time wasted on the start. At the second attempt the flag was lowered with the favorite on the lead, Mohawk in second position and the Canadian trailing three lengths behind. To the half mile these positions were unchanged, then Mohawk moved up a little closer, the jocks on both the leaders watching each other with jealous eye, apparently caring nothing for the trailer on their path.

Past the judges' stand on the first mile Mahone had a length to the good, Mohawk following, and Nettie still three lengths behind; round the quarter Mohawk responded to a call and closed upon the leader; a sharp skirmish took place to the half mile, resulting in the mare still having a half length the best of the argument. But now 
a new interest made itself felt. Leary, who all along had exhibited rare patience watching his leaders fighting one another, saw the critical moment had arrived, and, calling upon the "old slave," raced up to the favorites, went by them as if they were anchored and at the three-quarter pole had a lead of three open lengths.

The race home was a cut and come struggle between Mohawk and Belle Mahone; both were dead beat. Nettie, on the other hand, was fresh as paint, and raced home a winner of the dash with six lengths to spare, which could have been increased to twelve if Leary had wished to make an exhibition of the foreigners. The drop was a heavy one, the followers, both of Belle and Mohawk, were clean scooped, and the night train took away many a sore head that had swooped down on the pool box over night, thinking he had but to stoop to pick it all up. 


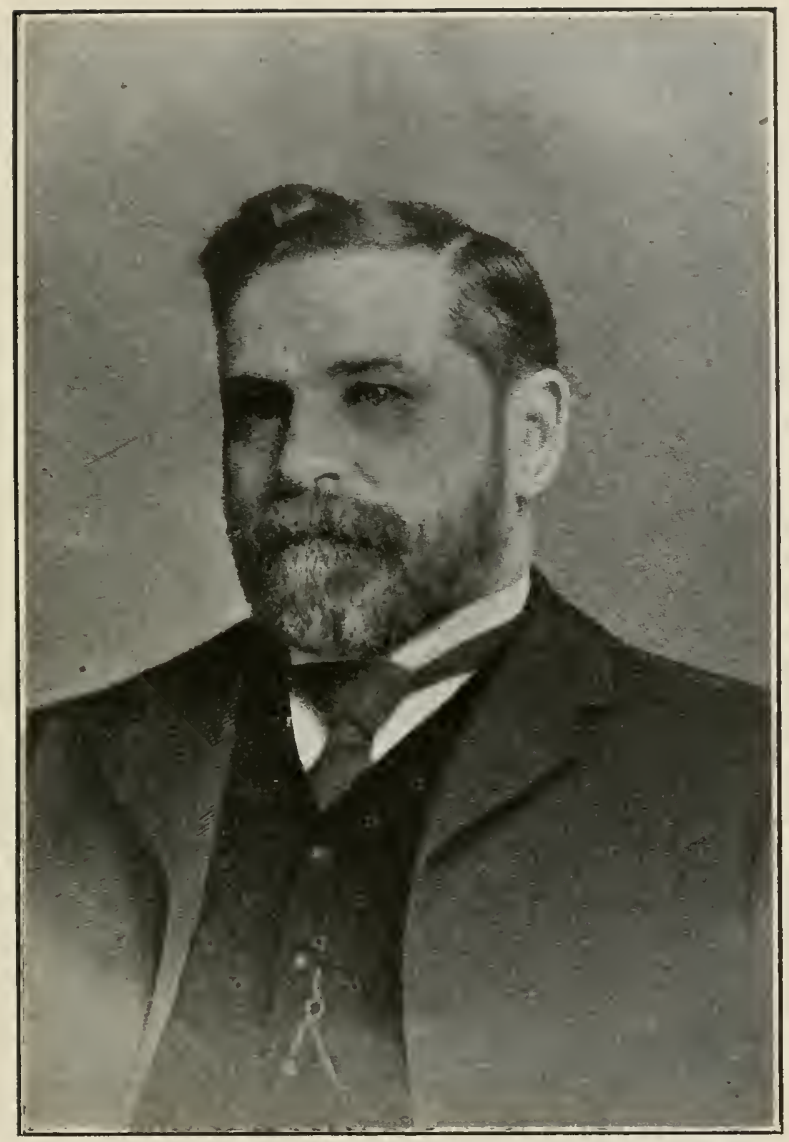

HUGH PATON, DIRECTOR MONTREAL JOCKEY CLUB. 



\section{FORTY AND FIFTY YEARS AGO.}

Every now and then I hear some of the young chaps grow rapturous about the wonderful progress the running turf has made in Ontario, and cite the Ontario Jockey Club meetings as proof of it. Now I quite agree with them so far as the big Toronto meeting is concerned. It is an improvement over any of the old-time meetings.

Nearly forty years ago the Whitby Club used to give some rattling good meetings, and purses of $\$ 400$ were no uncommon prize. Now grass grows over its track and the footfall of the thoroughbred hasn't been heard there for years. Hamilton in those days used to hang up thousands of dollars, and prominent men used to gather from all over the province; contests as keenly contested as any run nowadays were then witnessed, but for a long time the glory departed from there also, and it is only within a few years that the Hamilton Jockey Club has again popularized the silks and satins of the turf in the Ambitious City.

London was another popular centre, and on the old Newmarket track there was many a gallant contest in ye olden days, and good men and true gathered from all over to take the odds or lay them as their fancy decided. And what a jolly crew used to report the night before the opening day of the meeting at the Tecumseth House, the headquarters of the tribe. Business men, professional men and gentlemen of leisure would be there, all bound for the races and all bound for a good time, but all in correct form as became gentlemen who had a proper respect for themselves. Then again, down in the old Limestone City, on the old Cataraqui track, there were many good races and province-breds who could hold their own with the best of the present day, struggled through two-mile heats, and those terrible killers, mile heats, three in five. 
No man but a latter day crank can deny that there were some rattling good performers then. Memory serves up such good ones as Augusta, Allendale, Brown Dick, Montcalm, Verge, Julia Adams, Newcastle Maid, Twiligbt, Jack the Barber, Kenneth, Thunder, Harper, Tommy Wonder, Clarion, Blanche, Marksman, Don Juan, William Ashley, Nannie Craddock, Zig Zag, and a little later on Sir Archibald, King Tom, Lord Byron, Vespucius, Judge Durell, Vandal, War Cry, Carleton, Edenton, The Moor, Viley, Kelso, Jim Connor, Bonny Braes, Jack Bell, Jack on the Green, Milesian, Duffy and lots more that I can't recall to mind just at the moment, and those were the days when long distance racing was more the rule than the exception, and a meeting without mile heats was booked a dull affair, and many a gallant three-mile heat race in those days proved the stubborn gameness of the performers.

How many horses do you suppose, owned in Canada to-day could have stayed the trip with Verge, Julia Adams, Jack the Barber and William Ashley in their great three-mile heat race at Whitby, in June, 1862? The first heat was won by the mare in 5.411/2. The second and third by Verge in 5.34 and $5.381 / 2$, and weight for age was the impost. The day before on the same track, Julia Adams won a two-mile heat race in 3.38 and 3.41 ; Verge being beaten a length in the final heat and a scant neck in the second. The year after, also at the county town of Ontario, Thunder, with 122 pounds up, won a two-mile heat race in $3.42 \frac{1}{2}$ and $3.381 / 4$, Harper being lapped on him in both heats. Three and four thousand people used to turn out in those days, and though bookmakers were a betting medium unknown, yet a goodly quantity of dollars used to be wagered, and lots of prominent men of the community were not ashamed to be seen backing their fancy.

\section{AN ANCIENT QUEEN'S PLATE.}

I have heard it claimed a hundred times that no Queen's Plate was ever run in Canada before 1860, but the following, published some time ago by the Cobourg 
Star, is a fac simile of the bill issued by the Newcastle Turf Club in 1841:

“Newcastle Turf Club, June, 1841.

"President-D'Arcy Boulton, Esq.

"Stewards-The Sheriff of the Newcastle District, Geo. S. Boultbee, Esq., Donald Bethune, Esq., John Crawford, Esq., J. S. Innes, Esq., Wm. Weller, Esq., H. Covert, Esq.

"Treasurer-Wm. Weller, Esq.

"First Day, Tuesday, 22nd June-The Cobourg Plate of $£ 100$, free for all horses. Heats, two miles and a distance. Two-year-olds, a feather, three-year-olds to carry 6 st. 6 lbs.; four, 7 st. 9 lbs.; five, 8 st. 4 lbs.; six, 8 st. 10 lbs.; and aged, 9 st. Horses bred in British North America, allowed $8 \mathrm{lbs}$. The winner to be sold for $£ 200$, if demanded within one-quarter of an hour after the race. Entrance, $£ 5$.

“The Queen's Plate of $£ 25$, for horses (the bona fide property of subjects of Her Majesty two months before the day of running). Three-year-olds to carry 9 st. $3 \mathrm{lbs}$.; four, 10 st. 7 lbs.; five, 11 st. 3 lbs.; six and aged, 11 st. 7 lbs. Heats, one mile and a distance. Gentlemen riders. Entrance, £5.

\section{"A. G. Allan, Secretary."}

A glance at the above shows the Cobourg Plate in those days was worth a hundred sterling, equal to $\$ 500$ Canadian currency. In fact, I saw $\$ 600$ purses hung up in Toronto thirty-eight years ago. It will always be a debatable point that will be stoutly defended on both sides, whether we have made much improvement in breeding the thoroughbred in Ontario. Remember, that the present going at Woodbine is infinitely faster than the tracks at London, Hamilton, Whitby and Kingston were, and I'm not altogether certain in my mind, but that Nettie, Jack Vandal, Bay Jack, Terror, Jack Bell and such could hold their own with the present race of provincials.

Of course we hear a great deal about the naughty doings in those days, but page for page the record then was just as clean as it is now. "White man is mighty uncer- 
tain," according to Indian logic, and those who race horses now are no improvement on those of twenty or thirty years ago. Crooked men will try and get in their dirty work and occasionally they succeed in getting away with the trick. So long as grass grows and water runs these jobs will be attempted, and the turfmen of to-day cannot successfully throw stones at their predecessors on the Canadian turf of thirty-five years, at least, that is my opinion. 


\section{A NOTABLE MILE HEATS RACE, THREE IN FIVE.}

"Remember that disastrous coup?" "Well, I should head. Old heads commenced to shake and prophesy that old fellow, that day as hummers in a Mulmer swamp in the month of June." Such was the exclamation of an old-time turf friend when talking over the great mile heat race, three in five, that took place at Hamilton many years ago. It was a Waterloo, and no mistake. Jack on the Green, Bay Jack and Rathowen were in it, but in the opinion of the knowing ones it was a Gordon Setter against a yellow cur that Jack on the Green would land the trick. Archie Fisher was handling the favorite, and well I remember the confident manner in which Archie and his friends stood round the box over night in the Royal Hotel and backed their fancy. Jack on the Green, $\$ 50$; Bay Jack, $\$ 25$; Rathowen, $\$ 5$, and the field $\$ 4$, was about the average, and at these figures much money was placed.

Next day a goodly crowd gathered at the course, for those were the days when the gentry of Hamilton came to the front, and speculated a little in the pool-box themselves. The betting of the preceding evening was continued at about the same rate, and a heavy business was done. The first heat was a stubborn struggle from end to end, each horse in the race taking a turn at the favorite, but the latter managed to shake them off and landed the first instalment by a clear length. The apparent ease with which the favorite had won the heat made him a still hotter choice, and the backers of the stable, not content with what they already had on, plunged still heavier, evidently thinking they were finding it. In the second heat the favorite was well away; and rounding the turn got clear of his company, looking at that stage as if he easily had the foot of the party, but turning into the back 
stretch Bay Jack moved up and gave the leader a head and head struggle to the three-quarter pole. Here the London crack fell back, and Rathowen, coming with a rush, gave the favorite no let up. Down the home stretch the pace was hot, whips were cracking and a thousand voices added to the excitement of the finish. "Jack has it!" "No, Rathowen has him!" sounded from hundreds of throats. At the old draw-gates, Billy Flint, on Rathowen, makes still another effort and gets his horse's head to the front, but Jack responds to the call, and half way to the stand is again head and head. Once more Rathowen lets out a link, and a responding effort is made by the favorite, but the killing pace he has been kept at from the start with a fresh horse ready at every stage to take up the running had its effect, and in the last two jumps Rathowen forged to the front and gains the verdict by a head. Old heads commenced to shake and prophecy that the favorite's bolt was shot, but many others loyally stuck to their colors and some even dipped in at the reduced rate and got on a little more. The third heat was almost a repetition of the second. Rathowen made the running the first quarter, then Bay Jack set the pace for the next half, when Rathowen again came up for the finish. The run home was another desperate struggle, whip and spur being freely used and Rathowen again gaining the verdict by a scant head. Now a rush is made for the box, and fifty voices are shouting in the desperate attempts to get on. "Rathowen," "Rathowen," is the reigning cry, and soon the odds are on him, $\$ 50$ against $\$ 20$ on the field. Soon the jockeys are mounted for the third heat, backers of Fisher's stable in the meantime being busy figuring up their books, and counting how much they had saved from the wreck through the medium of their investments on Rathowen.

At the drop of the flag the latter jumped off with the lead, Jack on the Green laying at his side. This position was unchanged to the three-quarter pole, the two leaders being fully four open lengths ahead of Bay Jack. At this stage it looked as if the old struggle was to be renewed 
between the past and present favorite, but to the amazement of everybody, no sooner were the leaders fairly squared for home than Bay Jack made his run, coming up like a bullet. Down the stretch they come, a trio linked head and head. Once more whip and spur are brought into requisition and all the arts practised to gain a point. At the draw-gates Rathowen has a head the best of it, but half way from there Bay Jack makes another effort, and the salvos of "Hip, hip, hurrah," pronounce that the rank outsider has caught the judge's eye first. Once more the pool-seller's voice is heard, and again an excited crowd throngs the stand. Those who started in on the first favorite, and afterwards played Rathowen for a saver, are clamorous for a chance to hedge again, and soon Bay Jack rules at $\$ 50$ to $\$ 20$ over the party. The fifth heat was a grand struggle between the latest favorite and Rathowen, and I still incline to the belief that if Flint had shown a little more patience on Rathowen he would have won the heat; but he made his run too soon, and his horse, dying away at the draw-gate, was caught by the Londoner and beaten out by half a length. The sixth heat was an easy victory for Bay Jack, whose rest up in the first three heats now told hugely in his favor, and though a gallant effort was made by his company the little bay stallion shook them off and landed the richest harvest of the season for his backers. 


\section{A NOTED OWNER AND BREEDER OF THOROUGHBREDS.}

Mr. Joseph E. Seagram, President of the Ontario Jockey Club, and who for many years was the Parliamentary representative of North Waterloo in the House of Commons, is one of the best known men in the Dominion. Not only have the brands sent out from his distillery at Waterloo, Ont., made his name familiar from the Atlantic to the Pacific, but he is equally well known as a turfman and breeder of thoroughbreds. He has won the Queen's Plate ten times, and since the accession of His Majesty King Edward to the throne, he has landed the coveted honor three times. Some idea of the extent of his turf operations may be judged from the fact that he generally has at his Waterloo breeding farm about one hundred head of thoroughbreds and his string in training each spring, before the weeding-out process has been started, generally numbers about forty head. All the big stakes on the Canadian running turf have at different times been won by his horses, and many important events across the border have also been credited to his colors. For over twenty years he has spent money lavishly importing choice blood, both from England and the United States, and though, perhaps, the returns were not always up to what even reasonable expectations might look for, still there was no slacking off in the efforts to secure success.

Outside of the racing reputation gained by his stable, Mr. Seagram's work as a breeder of thoroughbreds has been of inestimable value to the country at large. The sales by public auction each year of his surplus stock has scattered broadcast over Canada hundreds of wellbred animals within the past fifteen years, and these were 
sold at prices at which any farmer could afford to purchase. The brood mares which did not produce speed at the Waterloo stud were, of course, failures from a racing point of view, but their blood has greatly enriched the equine stock of Ontario especially, and scores of instances are on record where the produce of these mares by ordinary sires have secured the highest honors of the show ring. It is also a noteworthy fact that many horses sold by Mr. Seagram at these public sales have proved successful race horses, in many instances winning from high priced animals belonging to their former owner. It is quite natural for people to say that an owner would not likely sell the pick of his horses, but might be expected to weed them out and dispose only of those which he thought were of the least value as racing property. That argument is all very well in theory, but it does not work out in practice. Where a trainer has thirty-five or forty horses to work it is not possible for him to give the same attention to the working of each which he would do if his attention was directed to the management of a much smaller number. Hence, horses have been sold out of the Waterloo stable at low prices that have won scores of races both on the Canadian and American turf. It is scarcely necessary to add that Mr. Seagram's colors, the famous black and yellow, are highly popular with the race-going public. That portion of it who back their fancy know they will have a run for their money and it is this public confidence that adds so much to their popularity.

Mr. Seagram, as President of the Ontario Jockey Club, is also an honorary member of the English Jockey Club, the most exclusive organization of its kind in the world, one which includes in its membership not only many of the most distinguished citizens of the Empire, but also a liberal number of the most notable men in Europe. 


\section{THE LATE WILLIAM HENDRIE.}

"He was a man; take him for all in all, I shall not Look upon His Like Again."

—Shakespeare.

To my mind these Recollections would scarcely be complete if I omitted mentioning the name of one who for so many years was a central figure on the Canadian run. ning turf; one who by his high example elevated the sport in the estimation of the people.

It has been my sorrowful duty on many occasions to note the death of men prominent in politics, in the professions, in mercantile, manufacturing and social life, but I never experienced keener regret than on the occasion of announcing the death of William Hendrie, in July, 1906.

He was a prominent contractor, and as the originator of the railway cartage business in Canada, displayed executive ability of the highest order-simplifying and systematizing what was before unsatisfactory and unsafesupplementing it by a rapid, safe and economical delivery of railway freight to consignees. The originator and director of many extensive business enterprises, he was justly entitled to rank one of Canada's greatest captains of industry.

Separate, however, from all his vast commercial undertakings, it is in a different capacity that he is better known to the Canadian people. As President of the Ontario Jockey Club and an honorary member of the English Jockey Club, he was par excellence our representative turfman. No man in the history of the royal sport ever raced, whether on the heath at Newmarket, at historic Epsom Downs, or at Ascot, who was a more thorough sportsman. His love of the thoroughbred was next to his love for his family. No sordid considerations 


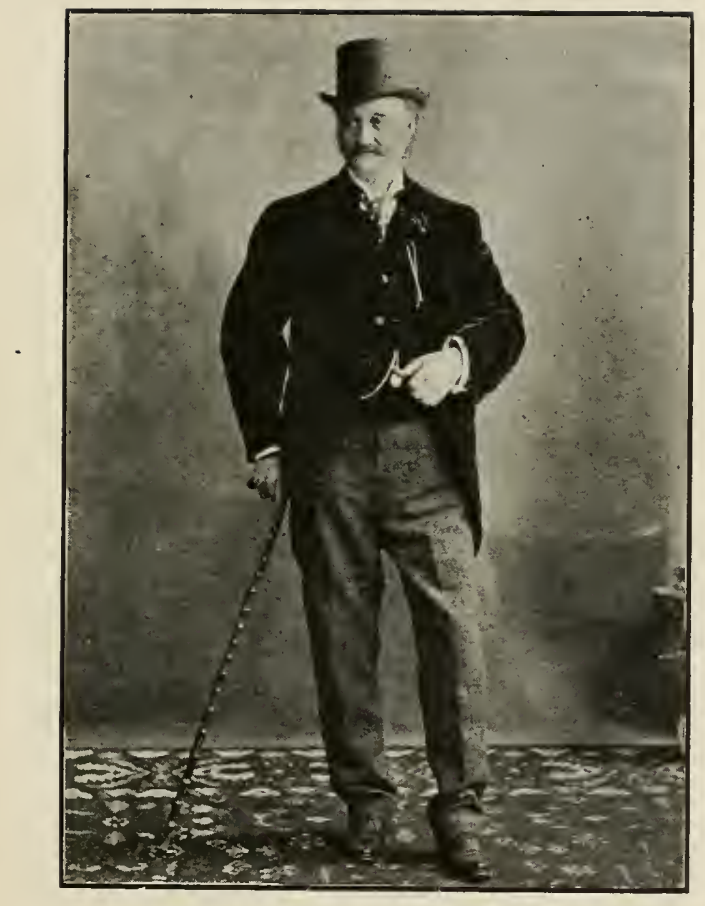

THE LATE WM. HENDRIE. 

of pecuniary gain ever entered into his calculations in connection with his turf career.

No happier hours of relaxation were passed by him than when wandering through the fields of his Valley Farm, watching the thoroughbreds, which, young and old, roamed its pastures. It may be that in the estimation of eminently practical-minded owners, who are in a big majority on the American turf, Mr. Hendrie's successes were not, from a dollar and cent view, proportionate to the outlay, but to one of his lofty ideals in all matters connected with racing, the question of profit never engaged his attention. Like all owners, he was fond of winning, but there never was an owner of race horses in any land who could lose with better grace or with more genuine warmth of feeling congratulate the owner who defeated him.

He never bet on his horses, not even the smallest sum. To him the pleasure of winning was all-satisfying and that satisfaction was intensified tenfold if the winner was one of his own breeding. I remember a few years ago a young turfman, whose horse had just been defeated by Mr. Hendrie's, turning to him, and with considerable warmth of feeling declaring he was willing to run the race over again in one hour's time and wager him one thousand dollars that he could beat him. Mr. Fendrie's reply came both prompt and decisive, but in courteous tones, he informed the would-be bettor: "I hope I am a sportsman, not a gambler." It was short, sharp and to the point, and it thoroughly bespoke the character of the man who uttered it.

Another striking illustration of his high quality as a sportsman is furnished by the following incident. A few days after his horse, Martimas, had won the Futurity of 1898, the greatest two-year-old event on the American turf, he devoted a large proportion of the money thus received to the construction of a wing to the Hamilton Hospital, which is now called Martimas Annex. A few days after his splendid colt had landed the great race, he also won the Flatbush Stakes, but was disqualified for an 
alleged foul. After giving their decision one of the stewards approached Mr. Hendrie and expressed regret that they felt forced, under the circumstances, to set back the horse of so genuine a sportsman. His reply was worthy of himself. Bowing to the steward in question, he calmly replied: "The money lost is of no consideration whatever. I am thoroughly satisfied, because my colt has proved himself the best."

His personal appearance was worthy his splendid qualities. Standing over six feet, straight as an arrow, even up to his later years; his broad shoulders crowned by a head of magnificent proportions; a handsome face, full of character and one that responded with a sunny smile to any remark that pleased his fancy; clean of speech, and one of the pleasantest of companions. A man of great wealth, every dollar of which was gained by the force of his own genius, illustrated by indomitable energy and unswerving integrity; a self-made man in every sense of the word, but, thank God, not one of those who are always worshipping his maker-namely, himself.

To those who have visited "Holmstead" it is scarcely necessary to speak of that princely hospitality which spread his fame as host far and wide. No lord of the manor, castle, or baronial hall ever welcomed his guests with a greater charm of manner and becoming dignity than the deceased sportsman. His words of welcome betokened the warmth of his feelings and his departing guests, as they felt the firm grasp of his hand, knew their host would be delighted to see them again.

The name of William Hendrie is now but a recollection but for long years to come it will remain green in the memory of those who had the honor of his acquaintance, and no matter how brilliant the future development of the Canadian turf may be, it will never count amongst its rulers or supporters a grander character than that of William Hendrie, the late President of the Ontario Jockey Club. A man of the loftiest character, of generous impulses, he was one of nature's truest noblemen. 
He had a strong regard for all branches of legitimate sport, but he had an almost passionate love for the thoroughbred and the sports of the turf. No honor was ever more worthily deserved than his selection as an honorary member of the English Jockey Club. Its members include some of the greatest and most historic names of the Empire. The following are a few of them:

Arthur James, Col. W. Baird, Stewards. His Majesty King Edward VII., H. R. H. Prince of Wales, H. R. H. Duke of Connaught, H. R. H. Prince Christian, His Majesty King of the Belgians, His Imperial Highness the Grand Duke Vladimir of Russia, His Highness the Khedive of Egypt, Duke of Devonshire, Viscount Donne, Earl of Dunraven, Earl of Durham, Earl of Ellesmere, Viscount Falmouth, Captain Greer, Sir Frederick Johnstone, Bart., Earl of Rosebery, Duke of Westminster, Duke of Portland, Duke of Richmond and Gordon, Marquis of Zetland.

Yet illustrious as is the record of names we have quoted, in conferring the honor of membership upon William Hendrie, they did honor to themselves, and had his life been spared to meet his fellow-members of the most exclusive organization in the world, he would have proved worthy company for the noblest sportsman among them. 


\section{A WELCOME ADDITION.}

The addition of such a name as that of Sir Thomas G. Shaughnessy, K.C.V.O., President of the Canadian Pacific Railway, to the list of Canadian owners of thoroughbreds is an event worthy of record in these pages. Men of great influence and some of them bearing names of historic interest in Great Britain, are owners of racing stables, and the prestige of their social standing and influence is a mighty factor in upholding the prosperity of the English turf. The King of England is the representative turfman of the Empire, and certainly his example has had an all-powerful influence for good in the management of turf affairs across the sea. The English Jockey Club is the most exclusive organization in Europe, and its roll of members, as alluded to elsewhere, includes the names of many men of world-wide reputation.

Here in Canada, where the field is so limited, we doubly welcome the addition of one whose name is known and honored from one end of the Dominion to the other. Sir Thomas Shaughnessy, by the force of his own genius, is to-day a central figure in the history of Canada and if his accomplishments in the next ten years are at all commensurate with his past performances, then indeed will he stand forth one of the most conspicuous figures in our national history.

His debut as an owner was made at the Montreal Jockey Club meeting in 1908, and it is an open secret amongst his friends that his appearance as an owner was due to his desire to support the Club, of which his friend, Sir Montagu Allan, is President, and the fact that his colors have many times been first past the post is eminently satisfactory to his admirers. It could not be expected that one, upon whose shoulders such great interests rest, could give his personal attention to a racing 
stable, but his name as an owner upon a Club's racing programme is a powerful assistant in popularizing the running turf in this country.

No feudal Baron in ye ancient days wielded more power than a modern railway magnate whose word, as in the case of the President of our great national highway, is law to thousands of employees; a slight idea can therefore be formed of his far-reaching influence which extends from the Atlantic to the Pacific ocean. Such a citizen is therefore a powerful addition to the Canadian list of owners, and that the success of his colors may be equal to the popularity of their owner, will be the earnest wish of every lover of our national sport. 


\section{A WELL-KNOWN AND POPULAR TURFMAN.}

The name of Dr. Andrew Smith of this city appears frequently in these "Recollections." He has for nearly half a century been a conspicuous figure in connection with turf affairs in this country. As an owner he was represented by many good horses, such flyers as War Cry, Inspiration, Helen Bennett, Lady D'Arcy, etc., etc., at different times wore his colors, and it is scarcely necessary to add that the latter were always a favorite with the race-going public. Not only as an owner, but also as a racing official, the Doctor has for many years been a central figure. As Chairman of the Executive Committee of the Ontario Jockey Club, he has for many years given both time and energy to the discharge of his duties and his unselfish services have had much to do in building up the present prosperity of our premier racing association.

He was principal of the Ontario Veterinary College for over forty years, and enjoys a national reputation as a veterinarian. He is a member of the Royal College of Veterinary Surgeons, and his scientific attainments and clever management of the College, not only made it known all over the American continent, but attracted to it students from every State in the United States, from every part of the Dominion of Canada; also from England, Scotland and Ireland.

He was Master of the Toronto Hunt Club from 1883 to 1894 , and during his occupancy of that position the Club increased both in numbers and prosperity.

A noteworthy trip of Toronto turfmen was one in 1870 when Robert Bond and Dr. Smith got together a party of twenty to go down to the Whitby races. The first named acted as whip of a rattling good four-in-hand, and a better 
performer in that line never sat on a box. It was a pleasant party, every one of the company being personal friends of the kind able to enjoy themselves without going to extremes. Favored by splendid weather, the drive down the Kingston Road was thoroughly enjoyed and the coach drove up to the Robson House with a splendid Jacksonian rush that fairly startled the crowd of Whitbyites assembled to welcome the visitors. Of the twenty who made that trip, only five of us are alive. The balance have weighed in. Green be their memory.

Though advanced in years the Doctor is a hale and hearty man. He still makes an annual journey to England, and while there attends a few of its great race meetings. No citizen of Toronto enjoys a more widespread popularity, and to quote the words of one who graduated from the Ontario Veterinary College more than twenty years ago, "He is a grand old man, whom everyone who knows delights to honor." 


\section{SIR H. MONTAGU ALLAN, PRESIDENT, MONT- REAL JOCKEY CLUB.}

The Montreal Jockey Club were fortunate in being able to induce Sir H. Montagu Allan to accept the Presidency of their Club. His social standing, added to his personal popularity, had a great deal to do in establishing the Club in public favor. Although never prominent as an owner of race horses, he has occasionally owned a few good thoroughbreds and won races on the provincial turf. He also has to his credit several good cross country events, including the Hunt Cup in 1893. He lately purchased several fashionably-bred brood mares in foal to noted sires, thus setting a good example that other men of wealth in Quebec might follow with much advantage to the Province. He was Master of the Montreal Hunt Club for three years. He is a bold, fearless rider, though not a reckless one, and is to-day, when he can spare the time to indulge in the sport, a rider invariably in the first flight. He is Vice-President of the Allan Line of ocean steamers, President of the Merchants' Bank of Canada, and also of several extensive industrial institutions. He is also Honorary President of the Montreal Amateur Athletic Association, which is the most influential organization of its kind in the Dominion. He is a staunch supporter of every branch of legitimate sport. His name is familiar to every business man in Canada as that of one who has wielded a powerful influence in developing the trade and commerce of the Dominion.

At Ravenscraig, his splendid estate in Montreal, he dispenses a generous hospitality. 


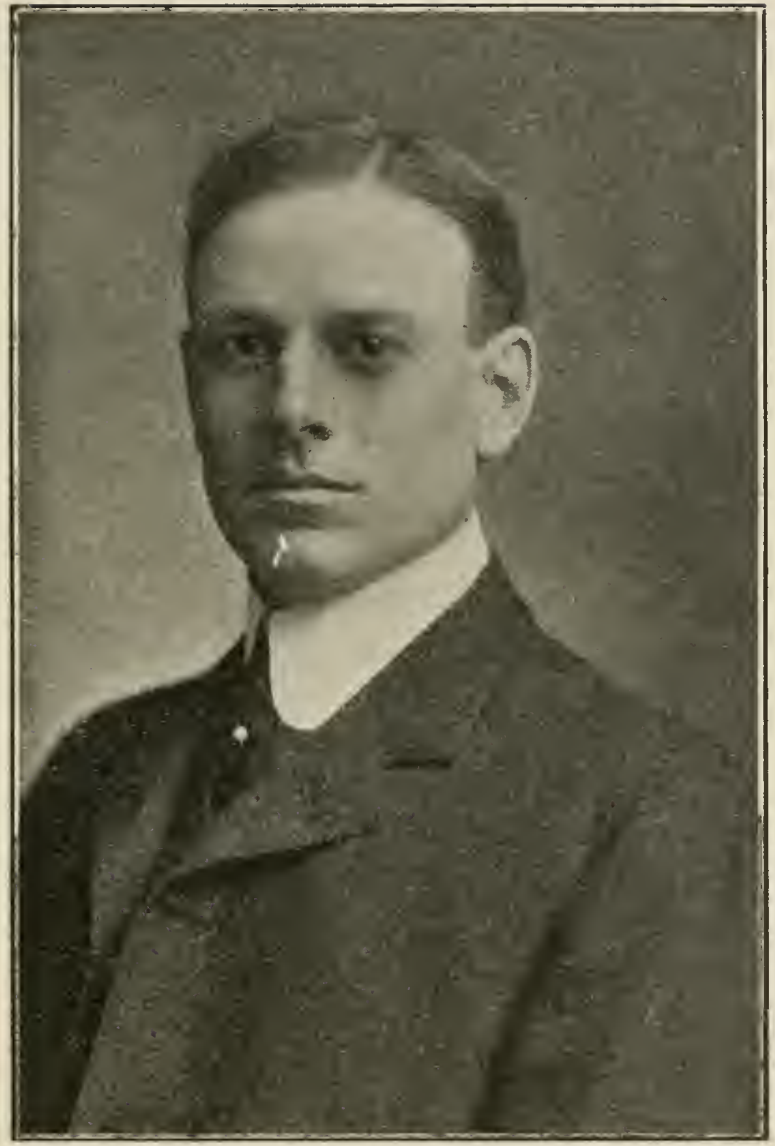

R. J. CHRISTIE, DIRECTOR ONTARIO JOCKEY CLUB. 



\section{DO YOU CARRY A RABBIT'S FOOT?}

A rabbit's foot for luck, is a solidly grounded belief in the minds of tens of thousands of the dark-hued sons and daughters of Africa, and many thousands also of their white brethren. Out in Arkansas you can buy them in all sizes; some mounted in silver, others of the baby variety, to be worn as a charm on the watch chain. If you wish to know full particulars of just how powerful a charm they are and the luck they bring to the wearer, just back up alongside of an aged Ethiopian, as I did once out in Little Rock, Arkansas, and get him started on what is, with so many of them, a favorite subject. This old coon was particular in impressing upon me what he pronounced "the important consideration," namely, You must start on the hunt precisely at midnight and the moon must be at its full. Your hunting ground must be in the cemetery, no dark clouds may obscure Luna's fair face, but her ghostly radiance must lighten up the tombstones and a slanting ray or so strike the church edifice. You must be armed only with a single-barreled shot-gun. The charge must be slugs eut by a jack-knife from a round stick of pig lead. Three of these slugs must have a cross marked on them. Your gun ready, you sit crosswise over the grave of a colored person who died at an age not less than three score years and ten. There you must sit and wait patiently the appearance of a jack rabbit. If he fails to make his appearance one night, you must continue your nightly hunt, when the weather is propitious, until the hour arrives when you have secured your game. Once this is done you cut off the four feet, then bury the body at the nearest crossroad. You must talk to nobody on your way to the graveyard, and you must be equally mum on the return with your spoils. 
Such was the assurance given me by the white, woolyheaded coon of Arkansaw, and so thoroughly grounded was his faith in this potent charm that it would have been cruelty of the most refined character to have made the slightest effort to uproot the faith that was in him. A friend of mine who accompanied me on the trip, became inoculated with faith in the yarn, and the following spring at the Woodbine races, armed with his rabit's foot, he proceeded to make his selections. He made four bets on the opening day, five on the second day and did not cash a single ticket. Mad as a wet hen at the result of his faith in the negro legend, he threw away bunny's pedal extremity. It was picked up by one of his friends, who carelessly put it in his vest pocket, more for the novelty of the article than for any faith in the charm it was said to possess. The next day he made three bets and won them all. The following day he wagered four times and won each time. And the third day the original owner, regretting his hasty temper, was around town hunting up the friend that had had such marvellous luck with the rabbit's foot.

Its succeeding history remains to be told, although I have heard it whispered that a charming young society lady of Toronto afterwards carried it concealed in a place the whereabouts of which was not likely to be known to any but her waiting maid. 


\section{JONATHAN SCOTN'S 400 TO 1 SHOT.}

Old Jonathan Scott died in the General Hospital in this city about three years ago. Well, the end must come to all of us, and the man who has swung around the circle for nigh on to eighty year's may expect that he is coming near to the end of his career. Did I say eighty years in connection with old Jonathan? Well, it is a hard matter to guess. He for years has been like a gnarled and withered oak-one that had withstood the blasts of centuries and whose knotted and rugged surface gave no indication of the earlier years of the world's history in which it was a sapling.

Jonathan was on the turf fifty years ago. Nearly forty year's back I remember him in charge of the Halton stable, the property of Mr. James White. He was then a very lame man. It was a difficult task for him to move around, but with all the drawbacks of painful physical infirmities, he was as cheerful a man as ever wore shoe leather. He raced east, west, north and south; had galloper's through the bushes on the half-mile tracks; raced at Saratoga, Monmouth Park, old Jerome and on every race course in Canada from Quebec in the east to Windsor in the west, and Jonathan was no slouch in the business, either. He had a heap of horse sense; had not a lazy bone in his body; was up with the lark in the morning and was ever faithful to his employer's interests. He did what no Canadian trainer, either before or after him, has accomplished. He started Balbriggan at Saratoga, against whom as good as 400 to 1 was on tap. The day before the race he advised two or three other Canadian trainers who were talking with him, to have a bet on his mare Balbriggan, the property of $\mathrm{Mr}$. O'Brien, of Montreal. They laughed at his pretentions, but the old man, solemn-visaged as an owl and earnest as a penitent 
at the bench, declared that they must run the race, seveneighths, in .28 or better to beat him, but though he was leading winners into the paddock when they were riding a cradle, they would have none of it. Balbriggan's victory was a veritable bolt out of a clear sky. The horses engaged in the race were eleven in number, and included a lot that classed up to the best selling plater form, such as Sandown, who only had 103; La Joya, with the same weight; Figaro, 99; Torchbearer, 98; Mary S., 98; Kentucky Lady, 98; Stonemason, 99; Skidaddle, 112; Leonardo, 94; Lehman, 100, and Balbriggan, 100. Mr. Fleischmann, the owner of Lehman, was very sweet on his horse's chances, and the whole stable connection had their coin down on him. His best race in Chicago was a mile and seventy yards in 1.45, with more weight up, and he also had many other fast performances to his credit, and his friends backed him as if the event were already won. The Seagram stable thought they had a royal chance with Stonemason, and hundreds went into the ring on his chances. Figaro was another red-hot choice, and thousands of dollars were staked on him, but the despised Canuck mare, with an unfashionable jockey up, that half the people present had never heard of, simply outpaced the whole party and beat them on their merits.

Now I will relate an interesting circumstance that occurred in connection with this race. Two friends and myself had strolled across the bridge from the public stand on to the balcony of the pretty little club house that had just been erected by President Walbaun. We were seated at a table smoking a cigar and sipping a light $B$. and $\mathrm{S}$. just before the race in question. Just in front of us at another table, were two ladies and a gentleman. The former were both good lookers and, judging by their conversation, were evidently enjoying their outing. A bottle of Pommery and three glasses proved they were no cold-water disciples and the conversation of the three clearly demonstrated that they knew very little about the racing game. Just then one of the commissioners passed around with the betting card. One of the ladies asked to 
be allowed to see the names of the horses that were going to start in the next race. Glancing over the card she spoke out quite loud enough for us to hear. Turning to her companion she said: "Why, Julia, here is one we should have a bet on. It's name is Balbriggan. All the girls know all about that useful article." The gentleman turned round and said: "Well, girls, do you want me to back Balbriggan, because if you do, here is my pile," drawing from his vest pocket three silver dollars. The ladies urged him to bet. The commissioner, a shrewd lad, said: "Well, sir, there is only 100 to 1 on my card on that horse, but they tell me there is 400 and 500 to. 1 against that one in the ring. If you like I will go down and get the best odds I can." The parties assented, and the boy went away and brought back a ticket bearing on its face the figures " $\$ 1,200$ to $\$ 3$." The mare in question belonged to Mr. O'Brien, a son of the late Senator O'Brien, then a prominent broker in Montreal, well known to myself and the two friends by my side, and I was well acquainted with the trainer, Jonathan Scott. I, however, had not met him the day before, or on race day, therefore had no opportunity of hearing his opinion of said mare; and we decided to remain there and witness the race without having any pecuniary interest in it. After one or two false breaks the whole fieid got away. It was a mixed-up race, first one and then another, until they got well into the stretch, when three or four appeared to us to be head and head fighting for the lead. It was impossible from our position to note the horses passing the stand until they came right opposite the judges' stand, when, to our intense surprise, we saw the head of Balbriggan in front, and the judges' verdict was "won by a head."

Neither of the ladies, nor their companion, had the slightest knowledge of who the winner was, and, turning around, I said to one of the ladies: "Excuse me for the liberty I take, but your knowledge of Balbriggan has proved a success." 'They were, of course, intensely astonished when I told them Balbriggan had won, and it was 
amusing to hear the two ladies at once commence to figure up what the $\$ 1,200$ would do in the shape of silks, satins and gloves. The gentleman, however, chimed in by saying: "This is a straight case of divide. I will keep the odd three dollars and we will whack up \$400 apiece." Just then the boy reappeared and asked for the ticket to go down and cash. The gentleman decided to go down himself and asked us, as a special favor, after being introduced to the ladies, to await his return. We did so, and when he came back his pocketbook was just $\$ 1,200$ richer.

Over a glass of wine we wished them continued success in the guessing line, and that day started a friendship which after years have cemented. 


\section{JACK THE BARBER SHAVES HIS BACKERS.}

Talk about taming a shrew! You could easier curb the temper of a zebra of the plains than soothe that crotchety provincial, Jack the Barber, if he felt in the humor for acting mean. On the flat he was a respectable performer, and as a jumper he was hard to equal when he inclined to go about his business, but if he made up his mind to play loafer not all the whips or spurs used by jockeys could move him along.

I have seen him when he was in decent humor, prick his ears and clear a twenty-eight foot water jump as if he were fond of it, and again I have seen him lug along and stumble over an insignificant six-foot ditch. When you had your money on him was his favorite time for playing mean, but if you didn't happen to back him for a single dollar, he was pretty certain to run as kind as a kitten. I remember once travelling to Ogdensburg in company with his then owner, Uncle Joe Grand. Jack had been entered in the hurdle race and steeplechase both, and though the company was formidable in quantity, the quality of the baker's dozen of contestants was not of high grade. In fact, if Jack was in decent temper, it was quail on toast against cold porridge that he could land both tricks. A triple partnership had been entered into between Uncle Joe of the first part and a well-known King street wine merchant who administered spiritual consolation of the second part, and a sporting journalist of the third part. Share and share alike in the expenses and an even divide on the winnings was the basis of the agreement.

Arrived at the Burgh on the morning of the day of the race, the three partners started to hunt up the horse which, under the charge of Brown, his trainer and rider, had been shipped a few days earlier. After nearly a two 
hours' search the stable was found, and in reply to enquiries Jack was pronounced fine as a fiddle and in good tune. Animated by the report an attack was made upon the pool-box. As many as six horses were sold out as choices, the balance in the field, Jack's average quotation being about four dollars.

At this rate all the tickets that were sold, about forty in number, were secured and mutual congratulations indulged in respecting the coup likely to eventuate in the afternoon. The race meeting was being held under the auspices of the Oswegatchie Agricultural Society and a large crowd of people were present.

On the track, preparatory to the start, quite a little additional speculation was indulged in at about the same odds, and as the horses faced the starter, Jack's actions were those of a well-mannered race horse. The distance was two miles over eight hurdles, and at the drop of the flag Brown, according to orders, moved about his business, and before a quarter of a mile was run had a clear length the lead of the party. At the stand once around the half-mile track Jack was three lengths to the good, running under a strong pull. At the mile he was four lengths on the lead, and running past the judges' stand at the mile and a half he still kept his place and, bar accident, it looked a brown stone front against a log shanty that the Barber would shave the party. As he moved to the turn on the last round Viley and N. P. made their run, and Mr. Grand signalled to Brown to give the horse his head and send him along. No sooner was this done than Jack moved away from his company like a quarter horse and the issue showed a dead certainty, but Brown, either through carelessness or over anxiety, touched him with the spur, when, quick as a flash, he swerved to the fence and commenced a hammering match on the boards with his heels.

So ended the coup, and the $\$ 1,400$ of winnings that a minute before had been almost in the pocket, faded away like many other such fabrics of similar vision. 
The next day in the steeplechase an effort was made to get even, and with an expenditure of sixty dollars the chance was bought to win eight hundred. But the brute's temper was up, and before he ran a quarter of a mile he commenced to show it, and coming to the water jump he sulked so badly that it was all Brown could do to keep him straight. When he got him to the jump he never raised a foot to the bank that faced it, but went head over heels, throwing Brown an ugly cropper into the fence corner. The race itself was a chapter of mistakes and accidents. Blackbird and two others went half a mile further than necessary. N. P., then well on the lead, through Blackbird's mistake, staked himself when running out from the field on to the track, and old Abbotsford, whose chances were appraised in the pool-box at $\$ 1$ in $\$ 30$, came along, and making no mistakes, landed on the track about three lengths behind N. P., who, though badly injured, and bleeding profusely, was making a gallant effort to finish the last quarter. Never was a pluckier effort made by an injured horse, but the loss of blood told the usual tale, and half a dozen lengths from home Abbotsford got on even terms and beat him out for first honors. The winner's owner, Dr. Coleman, of Ottawa, was so surprised that in his confusion of mind he ordered half a dozen of "fiz" and forget to drink any of it himself. The Doc. had a chance that day to harvest a great crop from a very trifle of seed. 


\section{THE PREACHER AND JACK VANDAL.}

I remember a very funny incident that occurred many years ago in the grand stand at the Hamilton track in a race won by Jack Vandal. A preacher had strayed into the ranks of the ungodly and was seated, along with a friend, an interested spectator of the races, not far from where I was located. A noisy fellow was shouting a desire to lay twenty-five dollars to ten that Vandal wouldn't win the heat, and was particularly pressing upon the preacher to have a shy at it. The offer was refused, however, with the declaration, "I'm not a betting man, sir. I hate gambling." Soon the flag went down and as the race progressed the noisy gambler kept on shouting: "I'll lay $\$ 25$ to $\$ 10$ Vandal don't win the heat." At the quarter Vandal was fourth, at the half he was third, and still the 25 to 10 was shouted. As they swung around the upper turn into the home stretch, the preacher, whose tall form gave him a bit the best of it in a neck-craning match, noticed that Vandal was up even with the leader and with sparkling eyes yelled to his friend, "John, take him up, take him up; take 25 to 10 , take 20 to 10 , take anything you can get, and by Jupiter I'll go you halves.' At this moment Vandal swept under the wire, winner of the heat by half a length, and a roar of laughter on the stand warned the preacher that the crowd had caught on to his lapse from morality. 


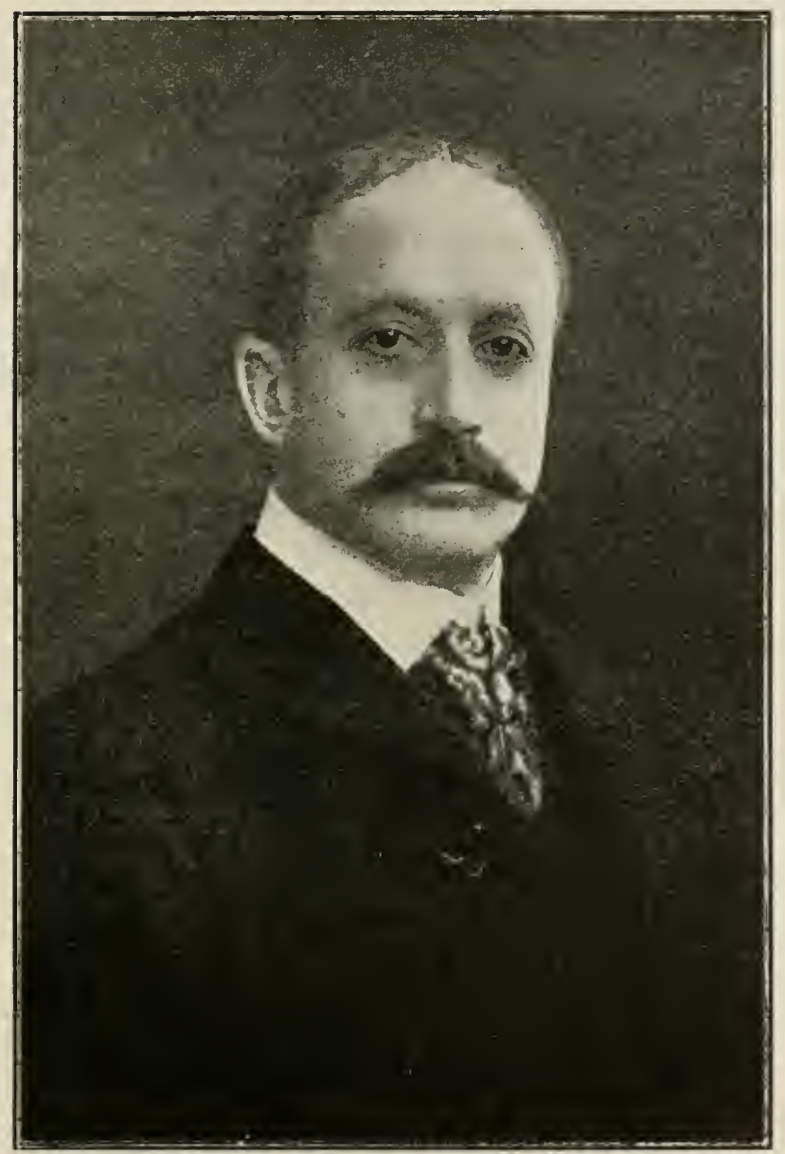

H. A. ALLAN, DIRECTOR MONTREAL JOCKEY CLUB. 



\section{THE LATE JOHN HENDRIE.}

John Hendrie, always called Jack by his intimate friends, was a man worth knowing. Over six feet in his stockings, broad shouldered, deep chested, slim waisted, well hipped, with underpinning above criticism, a man every inch of him and one well worth looking at.

Talk about a fearless horseman, I never met one quite his equal. Although a heavy man, weighing when in prime condition close on fourteen stone, his seat in the saddle was grace itself, and with hands light as a lady's dainty fingers, but woe betide the horse that tried to take liberties with him. I saw him once at his very best on as ugly tempered a brute as ever wore shoes. He was a big, raw-boned horse, standing $161 / 2$ hands, and had proved himself unmanageable in the hands of half a dozen who had owned him. He was bought for a song on account of his bad temper and his new owner determined to try him out.

I was fortunate enough to be present when he tried him, and I shall never forget it. It took a good deal of generalship to get into the saddle. Every trick known to the worst mannered broncho seemed to be familiar to this halfbred gelding, and short of lying down and rolling over he practised them. Finally, the mounting was successfully accomplished and the horse was given his head. His reply was to back up at his best speed, whirl suddenly around, then reverse himself; next, following this up by rearing and throwing himself backwards. His rider, cool as the historic cucumber, swung himself clear of the saddle and made the fact known to his mount by a few lively cuts that quickly brought him to his feet. Before the brute had time to practise any more trickery, Hendrie was in the saddle, and with whip and spur started him into a gallop. There was no let-up to the 
strenuous efforts of his rider; whip and spur were ready at the slightest indication of any faltering, and a good two miles was covered before the horse was given a breathing spell. When a halt was called, the Demon, as we had named him, was dead beat. Not so his rider, he was ready for a second test of endurance, but it was not necessary; the Demon was conquered and though nobody else was anxious to try his quality he was, in the hands of his master, Jack Hendrie, as tractable as a spaniel.

Under his guidance, while he was Master of the Toronto Hunt Club, splendid sport was enjoyed. In fact, those were the Club's palmy days. There were some crack rider's in the Club then and with such a Master to lead them it was a rare pleasure to see them in the field.

Arthur Godson, contractor, still hale and hearty; Robert Bond, the big cab proprietor, apparently as vigorous as ever; Gus Thomas, and Dr. Andrew Smith, still conspicuous in our midst, were especially noteworthy members. I have seen many hard riders in English Shires, and this lot were good enough to hold their own even in such choice company. Many good riders in those days were also to be found amongst the following members: Henry Godson (ex-collector of Inland Revenue), spare of form, but still erect and almost daily to be seen on King street. Others, now deceased, were W. Copland, J. M. MacFarlane, Charles Moore, Joseph Walker, Mr. Hagel, Lewis Reford, John Leys, Walter S. Lee, T. Jones, George Hastings and John Donaldson. Others there were equally worthy of mention, but enough have been named to show that the Toronto Hunt Club in the days of yore was composed of sportsmen of high class.

In addition to the civilians many of the officers of regiments then stationed at Toronto used to take part. Conspicuous amongst them were Col. Jennings, Capt. Moore, Capt. Higgins, Major Hubbard, Lieut. Spilling, afterwards Colonel of the famous Thirteenth Hussars, and many others whose names I have forgotten. 


\section{A TRUE SPORTSMAN EVERY INCH OF HIM.}

Handling a breech loader through the stubble or over decoys, or, rifle in hand, on a still hunt, or casting the fly for gamey trout or bass, my old friend Roddy Pringle was a good performer. As a horseman he had few equals, and as a turfman his career was above reproach. He was an all-round sportsman of the highest type and his death at a comparatively early age was sincerely mourned by thousands who had the honor of his acquaintance.

I passed many a pleasant day during a series of years in his company here in Canada and at important racing centres in the United States. He could not be called a betting man. True, he was ready to back his opinion, but he was not one of those turfmen who take no pleasure in watching a race unless he has a pecuniary interest in the result. Many a day he did not wager a dollar, but vet took as keen an interest in the struggles of the thoroughbreds as if he had thousands at stake.

My old friend was among the handful of true sportsmen who kept the turf spirit alive in Ontario after the departure of the British troops and the advent of the hard times which followed the American war.

For at least twenty-five years the fate of Canadian flat racing and steeplechasing trembled in the balance. What between the then greater popularity of the trotter, the scarcity of good thoroughbred horses, and the still greater lack of thoroughbred horsemen, it was a hard struggle to preserve the running turf from total eclipse. Had it not been for a faitlful few, who manfully, for sheer love of the thoroughbred, and often at great personal and financial sacrifice, stood to their guns and kept the old sport alive, the trotter would have had it all his own way, and the men of the present day would not have their Woodbine, nor would many of our modern Canadian breeding studs be in existence. 
The disappearance of the thoroughbred stallion from the concession lines would also have been severely felt in a province, which, as it is, lacks altogether too much a proper appreciation of his value.

It was Mr. Pringle's opinion that only through actual performance on the turf, the game, stout thoroughbred could be maintained, and that none but those who had carefully studied the question could realize the important part played by this strain of blood in improving the quality, as regards constitution and conformation, of the light-legged horses of any country.

Even as matters stand, there are in Canada too large a number of coarse, low-bred weeds, and had it not been for the enthusiasm and enterprise of a few individuals who, during the last three or four decades saw to it that the thoroughbred kept his place on the course and in the show-yard, the state of affairs would be infinitely worse.

Among the loyal friends of the thoroughbred in those dark days, "Roddy" Pringle ranked high. An all-round lover of decent, clean sport, he was an exceptionally good horseman, and although, as a rule, self-contained and undemonstrative, no man better enjoyed a close finish, or was more keenly enthusiastic when his choice finished first past the post.

Mr. Pringle was the owner of many well-known horses, among them that good race mare Mignonette, who won the Queen's Plate in 1873, being the first three-year-old to win the Canadian Classic.

Later an intimate and mutually cordial friendship between him and Dr. Andrew Smith, led to their being associated in the ownership and development of some of the best thoroughbreds ever raised in the Dominion.

Out of the famous imported mare Castaway, by Zetland out of Castellan, they brought to the starting post a whole family of horses, almost all of which proved noted winners, some being of exceptional merit. Among these the noted grey mare Lady D'Arcy, by Thunder, a son of Lexington, held for two years the three-quarter mile record of the American turf, no small honor for a Cana- 
dian-bred, competing with the flower of Kentucky and Tennessee, to say nothing of the big studs of New York and New Jersey.

Another good one was Roddy Pringle, by Helmbold, who, after winning the Queen's Plate in 1883, beating among others the speedy Princess by Princeton out of Roxaline (later a noted smasher of records on the American turf), raced as a gelding for many years, and was still winning in the nineties.

Many good horses, both province-bred and imported, ran under the joint control of Mr. Pringle and Dr. Smith, and although there were in Ontario, during that trying period, other men to whom much credit is due, it is doubtful if any achieved more than these two did with the means at their disposal and in face of the difficulties of all kinds which they had to encounter.

Many men are in the racing game for the money, while others, "having the price," as the saying goes, take it up as a fad or a fancy, caring little what it costs them. Both of these classes are useful and necessary, but in Ontario thirty years and more ago, there were few, if any, of the latter sort, while the former, if given full swing, would soon have ended the sport.

The racing men of the present generation owe, in a greater measure than most of them realize, the preservation of the Ontario turf to the single-minded efforts of a little coterie of keen, clean sportsmen, who loved racing and the race horse for themselves and not for gain or glory.

I have referred to our associations at the important racing centres of the United States, and no more pleasant days ever were than those we passed together at Saratoga, many jovial hours being spent on the verandah of Charles Reed's splendid residence on the avenue leading to the race course in the company of the Master of "Fairview." Stories enough to fill this book were told there. The host himself could tell a good one, and many of his friends were good seconds. "Charley" Reed, as he was generally called by his intimates, was a first-class 
entertainer. The company rarely broke up before midnight and it certainly was pleasant on a moonlight night to look out upon the splendidly kept grounds of the Reed mansion and the superb elm-shaded avenue on which it fronted.

At one of these pleasant reunions a younger member of the company was rather boastful of his ability as an amateur foot-runner. Warming on the subject he stated he would wager a basket of "fiz" that he could run seventy-five yards faster than any amateur of our acquaintance. "You are a good many years younger than I am, but make the distance fifty yards and I will take a crack at you myself." Such was the quiet reply of my friend Pringle, and when the boaster asked when the event should be pulled off, the answer was, "right now on the Avenue." Both parties agreeable, we adjourned to the ground selected, and as there was neither a vehicle or person in sight it was a clear field with no obstacles in the way. The fifty yards were duly measured; the judge was appointed and I was selected to do the starting. Both gentlemen promptly responded to my request to toe the mark, and on their affirmative response to $m y$ query: "Gentlemen, are you ready?" I said, "Go!" They went, my friend Pringle playing pathfinder all the way. The beaten one remarked: "By George, I was not expecting to run up against a ghost by moonlight." The "fiz" was promptly supplied, and many a pleasant chat was indulged in on the same piazza over its consumption.

"Roddy" Pringle held and still holds, in the hearts of those who knew him, a place of high honor. Kindly, gentle and genial, a sportsman for sport's sake, he stood, without fear or favor, for fair play and square dealing. His influence was all for good and turfmen, in Canada and elsewhere, who knew and loved him, will ever keep his memory green, and recall in association with his name the good old days of yore when men went to the races more to enjoy the sport than for the sake of the money that could be made out of it. 
His last resting place is at Cobourg, the town he loved so well. I also am fast nearing the other shore and I sometimes ask myself the question: "Will old friends meet again and old friendships be renewed?" Mystery of mysteries is the great hereafter. Who can tell? 


\section{A REPRESENTATIVE RAILWAY CONTRACTOR AND TURFMAN.}

Back in the '70's Mr. John Shedden, head of the great railway contracting firm of Shedden \& Co., was one of the representative turfmen of Ontario, and his farm at Davenport, a few miles northwest of Toronto, was a pleasant resort which his friends often visited.

He owned the thoroughbred stallion Thunder, by Lexington, a gray horse of great speed and endurance which, after a most successful racing career in the United States in which he defeated many of the best horses in training, running long distances and winning many long drawn out heat races, was brought to this country by the late Henry Hogan, of Montreal, from whom Mr. Shedden purchased him. He also imported Castaway, Sweetbread, Poetess, Fidget, and other mares. Just when he had decided to extend his operations as an owner, his untimely death ended all. He was President of the Toronto and Nipissing Railway, and was killed on the return journey of the first passenger train that inaugurated the opening of that road. He was one of the most popular men of his day, and at his residence on the corner of Spadina avenue and King street, he dispensed a hospitality unsurpassed by any other citizen.

His nephew, Mr. Hugh Paton, of Montreal, whose portrait appears in this book, is quite as strong a lover of the horse as was his popular uncle. In the early ' 80 's he won three Queen's Plates for the Province of Quebec, and many other events both on the turf and field, including the Montreal Hunt Cup in 1889. He is a Director of the Montreal Jockey Club, and it is the presence of such men as he on the Board of Management that has so speedily elevated the Club in popular favor and ensured for it a gratifying success. Personally, he is one of the most genial citizens of the commercial metropolis, and both in his city and at his country residence is as popular a host as was his uncle thirty years ago. 


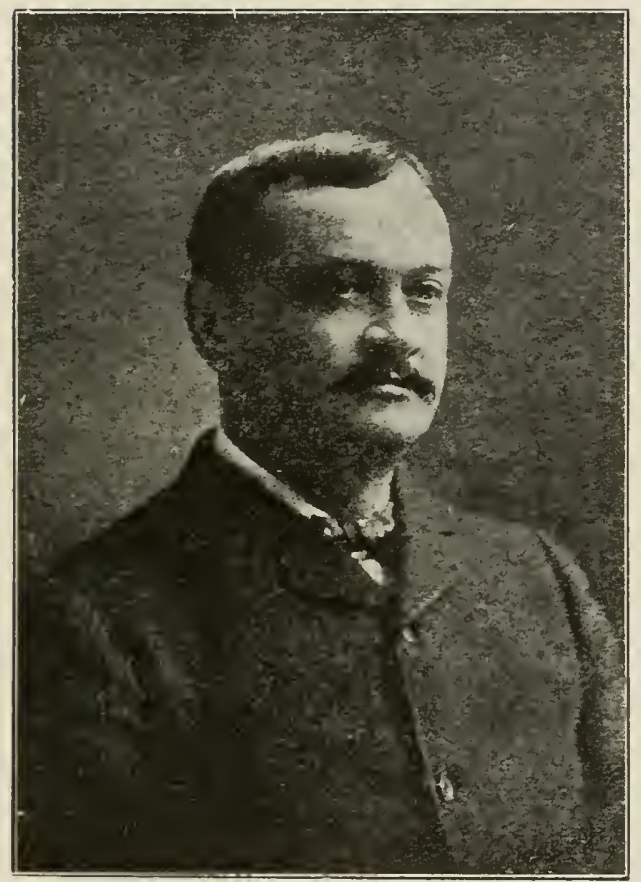

E

JAMES CARRUTHERS, DIRECTOR MONTREAL JOCKEY CLUB. 



\section{ANGUS SINCLAIR, A FORMER NOTED BREEDER OF TROTTERS.}

It will be generally admitted that the light harness horse is the most popular equine in Canada. When due regard is paid to mating sire and dam he is not only a good looker, but possesses speed, a valuable qualification with those who have much driving to do. A very marked improvement in this class of horse has taken place in Canada within the past twenty-five years. Time was when anything possessing a little speed would pass muster, but the intelligent perseverance of a few men in Ontario accomplished wonders in improving the quality. Conspicuous above all others in this respect stands the name of Angus Sinclair who, when proprietor of the Roslyn Stock Farm, Chatham, was a central figure in connection with the breeding of the light harness horse in Ontario.

His importation of the standard-bred sire, Wildbrino, 2.19, by Hambrino, introduced at that time not only the fastest, but one of the best bred horses ever brought to this country. It required a good deal of nerve to pay the high price which Mr. Sinclair did for him, because Wilkes blood was then all the rage and anything outside of that strain was looked upon with distrust. The wiseacres, those who pretend to know it all, also predicted that the high service fee charged utterly precluded the possibility of the horse receiving much public patronage. In this, however, they were mistaken. His owner, a strong believer in the power of printers' ink, advertised him liberally, with the result that not only was an extended patronage secured, but a fine quality of mares was also attracted to his court. The superior quality of his stock thoroughly justified what had been written about him and at an early age his sons and daughters furnished 
the superlative test of merit by securing fast records. His first crop of colts produced Violet, two-year-old record to high-wheel sulky, 2.311/2; the second produced Wild Crocus, two-year-old record, $2.253 / 4$, and each year afterwards added to his success as a uniform sire of speed with native mares. What he could have accomplished if mated with better bred mares can be judged from the fact that to a granddaughter of Red Wilkes he produced General Brino, 2.071/2, and to a daughter of Red Wilkes, Major Brino, 2.051/2; but not only has he proved himself a remarkable sire of speed, but the superior style and quality of his get have also secured for him high honors in the prize ring altogether outside of their speed qualifications. Again, in transmitting speed he also imparted that stamina and endurance which stand the test of long drawn out races-in a word, the blood that sticks.

Many of his sons are also distinguishing themselves in the breeding ranks, and altogether it is within the mark to say that Wildbrino is one of the greatest standardbred sires ever brought to this country. It would be interesting, if one had the time to make the necessary enquiries, to figure out the actual cash value of his descendants. I do not mean by attaching fancy figures to any of his produce, but by recording the prices which were paid for the most noted of his get. It is by such substantial tests as these that the true value to a country of well-bred stock is made evident. Yearlings and two-year-olds by Wildbrino were eagerly bought at prices ranging from $\$ 200$ to $\$ 1,000$, and in several cases of exceptional merit even larger figures were offered.

Now, as it costs no more to feed a well-bred one than it does to raise a mongrel bred, it is not necessary to advance any argument to prove the immense benefit, not only to the breeder of such stock, but also to the country in which it is produced. Again, there is nothing of the lottery game about such breeding industry. True, a farmer may not secure exceptional speed, but if he exercises a fair amount of common sense judgment in selecting good-looking, sound mares and breeding them to a 
stylish well-bred sire having speed, he can reasonably rely upon securing stock which, even if not gifted with exceptional speed, will possess the necessary quality and style to command a highly remunerative price in the market.

The heavy demands upon Mr. Sinclair's time, through his railroad contracting business, compelled him to relinquish the breeding of the light harness horse. It was to him a fascinating occupation and his withdrawal was a distinct loss to Canadian horse-breeding interests.

Every now and then a scare is started about the decadence of the horse. First the bicycle, next the automobile was to drive him off the road. Yet to-day handsome, wellbred animals, whether for carriage, saddle or ordinary driving purposes, never commanded a better price, but it is a notew orthy fact that the advertising columns of many newspapers are crowded with advertisements of autos for sale. I do not mean to imply that the latter class of vehicle has not its use, but I do unhesitating assert that any vehicle which costs $\$ 1,000$ a year to keep in repair and for supplies, is not an article that will ever supplant the horse in public favor. To those who can afford the expense of a chauffeur the annual outlay would be vastly increased, so that the modern juggernaut is a costly luxury which can only be enjoyed by those possessing ample wealth. 


\section{HOW SIX HOOKS REFLECTED SEVEN.}

Yes, there were only six metal hangers attached to a frame hanging across the door which led from my friend's room to my own at the Clarendon Hotel, Sara-. toga, but at the angle at which the door was open seven were reflected on the wall. When I first noticed the increased number I thought I was mistaken, but a closer inspection proved otherwise. There were but six hooks on the frame, but there was an extra one in the reflection. My friend was anxious to know what was so closely attracting my attention, and on my explaining the phenomena he also scrutinized the apparition and was equally surprised. One glass of whiskey and soda could not be chargeable with the illusion, so mentally concluding it was a puzzle which would demand the attention of a scientific mind to solve, we dropped the matter.

The next night, sitting in the same position, the reflection on the wall showed the same, and my friend suggested, merely out of curiosity, that I should look over the racing programme which had been run off that day and note if number seven had cut any figure in the results. Here is exactly what it did:

In the first race eight starters went to the post and number seven on the "card" proved the winner. In the second race nine two-year-olds faced the flag, and again number seven landed the coin. In the third event there were but five starters, so that to reach seven it was necessary to count the nominations from number one to five and then recount from number one a second time. This made number two on the "card" figure out seventh and he also came home first. In the fourth race there was a big field, and again number seven was the first to catch the judge's eye. In the fifth race, which was the last, number seven finished second, but as the odds 
against him for the place were three to one, the investment, if he was backed both ways, would have proved a profitable one.

Figuring it out at the time proved that a five-dollar bill invested to win and for place on the winner of each race at the odds obtainable, parleyed through the card, would have won a trifle over ten thousand dollars. Of course such revelations as these are never forthcoming until after the events have transpired. If they were, millionaires would be as plentiful as skeeters in Temiscaming in the fishing season. 


\section{A DAY OF SENSATIONAL LUCK.}

You can call it blind luck or any other name you prefer, I am not troubling myself about what would be the most suitable term to apply to it; I am simply relating a circumstance that occurred a few years ago at the Saratoga race meeting, and as the facts of the case came under my personal observation, I can vouch for the truthfulness of the story.

As I was leaving my hotel on the day in question to drive to the track, the manager introduced to me a gentleman whom I had previously noticed was a guest at the hotel. I had been keeping a carriage waiting for ten minutes at the door to accommodate a friend, also a guest, who was going out with me, but at the last moment had changed his mind, and as there were but a few minutes in which to reach the course before the racing commenced, I was making all possible haste to get away. The gentleman in question was also anxious to get to the track, and I was asked if I would be willing for him to drive out with me. Satisfied to have his company, the necessary permission was given.

On the way out he told me that this was his last day at the Springs. He had spent a pleasant two weeks' holiday, but frankly confessed that he had not been a success in guessing the ponies. He said he had brought $\$ 400$ with him for his expenses and of this he had a tendollar bill left with which to make a final plunge. He had provided himself with a return ticket, paid for his reservation in the Pullman and an additional $\$ 5$ for provisions on the road. This was securely packed away in his valise, and he proposed investing the remaining $\$ 10$ on the longest shot on the board in the first race. Mentally, I concluded that he would likely be wiped out in short order, but as it is never safe, in such cases, to 
give advice, I refrained from doing more than express the hope that he would guess them aright.

True to his word, as soon as we arrived at the track he walked away to the nearest bookmaker and I, not being interested in the race, went up on the grand stand. Immediately after the race was run I walked over to the betting ring, and there found my newly-made acquaintance standing in the pay line, and as I walked down that way he beckoned to me and showed me his ticket, which called for $\$ 210$. He had backed a 20 to 1 shot and landed. Congratulating him on his good fortune I left and saw no more of him until after the finish of the second race, when I noticed him again standing in line, waiting to cash another ticket. He speedily joined me, showing a roll of $\$ 1,000$ which he had just drawn. His second investment had been $\$ 200$ on a 4 to 1 shot. Thinking that he would be more than satisfied, I asked him if he had made up his mind to give them a rest. He replied: "No, I feel this is my lucky day and I am going to play the hand out."

Wishing him good luck, I joined a party of friends and saw no more of him until after the finish of the last race. He then came over and insisted that I should join him in a drive back to the hotel. This I did, and, inviting me to his room, he unloaded his wealth, and there in good bank notes was $\$ 6,785$. Certainly, it was a case of persistent good luck, and he was wise enough to leave for home that night with his treasure.

The following year, while standing in the rotunda of the Grand Union Hotel at Saratoga, I met him again. He then introduced me to his wife, a charming little lady to whom he had been married about three months. He also informed me that on his return to Boston he had invested the money so rapidly gained in purchasing a gents' furnishing store which was turning out a profitable investment, but, with a look of pride and satisfaction on his face, he said his choicest investment of all was the little lady to whom he had just introduced me. On my expressing the hope that he was now satisfied to 
let well enough alone and not again try another plunge of the same character, he answered: "I never bet more than $\$ 5$, and I have not made more than one bet each day I have been here. I have no desire to figure as a plunger."

The case was one that rarely happens. Here was a man destitute of any knowledge respecting the quality or chances of the horses engaged in any of the races on the day on which he made his bets; yet, in each and every race on the card, six in number, he staked his money and won. It was simply a case of blind luck and such rarely happens to any man, least of all to the man who wants good fortune as badly as he did on the memorable day in question. 


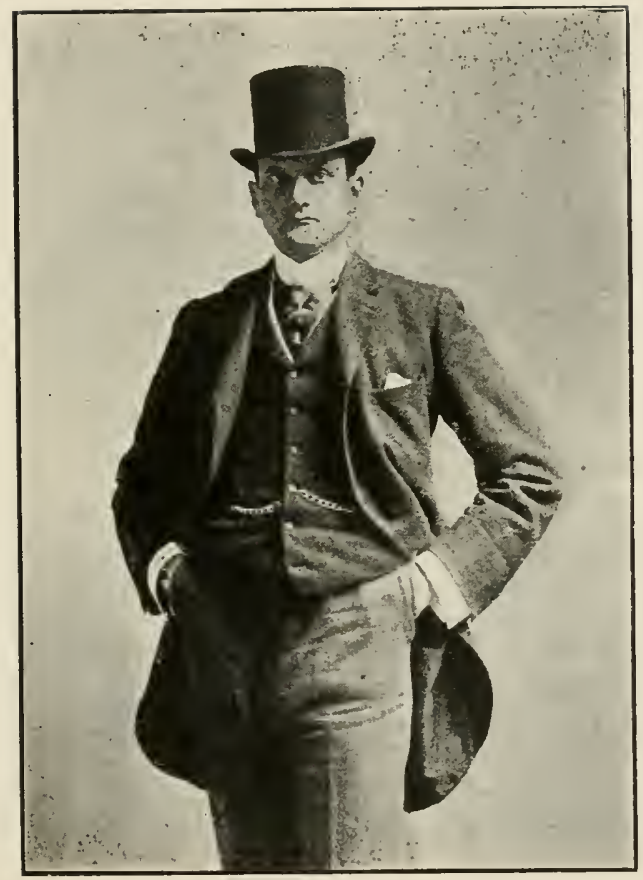

COLIN CAMPBELL, DIRECTOR MONTREAL JOCKEY CLUB. 



\section{CANADA'S VETERAN TRAINER, CHARLES BOYLE.}

There are many popular trainers of thoroughbred horses in Canada, but I may, with certainty of not offending any one of them, designate Charles. Boyle, of The Firs, Woodstock, dean of the craft. It is close on forty years ago that I first made his acquaintance. He was then, as now, all horse, and nobody, even in those earlier days, could talk more interestingly on the subject than he. I well remember one May morning in 1870. I, along with a party of friends, was swinging around the circle of stables at Whitby, looking over the horses that were entered in the races under the auspices of the local turf club-the only stable accommodation in those days being at the various hotels. It was in the yard of the Royal that I met the subject of these remarks, and at the time of my visit he was busy at work on a roan horse called Rapid Roan, which he had entered in the Queen's Plate, to be run on the following day. He started, but in the opinion of his trainer his lot in life was not that of bearing a silken jacket and, changing his name to "Rapid Ruin," he speedily disposed of him, and the last I heard of the roan was that he was doing duty between the shafts of a buggy in a livery stable at Orangeville.

It is not necessary for me to enumerate all the horses Charles Boyle has handled. To do so would be to fill many pages. It will be sufficient to mention some of the noted ones that he brought to the post. Among those of the earlier days were such good performers as Vespucious, Judge Durell and Musketeer, and a mare that gained him a good deal of credit at the time was Inspiration. She was brought over from the States and came here with a reputation of being a fair sprinter, but under his clever handling she proved able to go all 
distances, and afterwards won many rich stakes on the American turf.

War Cry was another good horse trained by him. He won the first Canadian Derby at Barrie, and afterwards scored in many important races, both in Canada and the United States. Charles Boyle entered into partnership with Charles Littlefield, under the style of Boyle \& Littlefield, and for several years they occupied a prominent position among the owners of horses on the American running turf. A few of the good ones that wore their colors were Miss Maud, Peacemaker, Halton, Eagle Bird; Havoc did them good service also. He was one of the best sons of his illustrious sire. He raced successfully at all distances, and won in first-class company both at the big meetings in the east as well as the west. He has since done eminent service as the premier sire at $\mathrm{Mr}$. Seagram's Waterloo establishment. Inferno, the fastest provincial yet uncovered, is by him, and quite a number of other winner's on the Canadian turf have been sons and daughters of his. Springfield was another of friend Charley's star performers.

After the dissolution of the partnership between Messrs. Boyle \& Littlefield, the former returned to Canada, and shortly afterwards took the position of head trainer for the Seagram stable. During the time he filled it Mr. Seagram's color's were to the front in many important stakes, not only in Canada but also south of the border line. Were I to enumerate all the good races he has won with llorses of his training, I would occupy many pages of this book. Suffice it to say that he ranks in the front row of Canadian trainers. Few men possess greater ability. He has a wonderful knack of preparing a horse for a special effort and, bar accident, you can rely that when race day comes around, his representative will be in the very pink of condition. Briefly stated, he is one of the few trainers who can get a horse ready almost to the hour he is wanted.

Outside of his ability as a trainer of thoroughbreds he is one of the pleasantest men you could possibly desire 
to meet. Thoroughly conversant with the racing events of the past forty years and blessed with a good memory, he is a most entertaining companion.

Though well advanced in years he is a hale and hearty man and gives as close attention to his horses in training now as he did twenty years ago. He has the wellwishes of a host of friends. 


\section{CANADIAN OWNERS AND THEIR COLORS.}

The following is a record of the principal owners of Canadian racing stables. The list is not a long one, but it includes the names of owners whose colors have won many important stake events at American as well as Canadian race meetings. Not only at the principal eastern meetings, but also in the west and as far south as New Orleans, Canadian-bred horses have scored notable victories.

Joseph E. Seagram, President of the Ontario Jockey Club, owns more thoroughbreds than any other man in this country, and his victories during the past twenty years, both at home and abroad, would take many pages of this book to chronicle.

The late Mr. William Hendrie was also a notable figure on the turf, both here and south of the border line. Two of his sons, Lieut.-Col. Hon. J. S. Hendrie, a member of the Ontario Government, and Mr. George M. Hendrie, of Windsor, with a large string of horses, are worthily upholding the reputation of the Valley Farm stable.

Robert Davies, Squire of Thorncliffe, a magnificent estate of about one thousand acres, just outside the city limits, is also another prominent figure as a breeder of thoroughbreds. His colors are often to the front and none are more popular with the racing public, who know that the stable is always striving to win. Mr. Davies has imported many thoroughbreds from England, and his premier sire to-day at Thorncliffe is Orme Shore, by the great Orme (sire of Flying Fox, which was sold for $\$ 187,500$, the highest price on record for any horse). Three of the get of Orme Shore made their first appearance on the turf at the spring meeting in 1909, and the fact that all three of them proved winners is substantial 
evidence of their sire's quality. The names of the trio are Shore Lark, three years; French Shore, three years, and St. Cecilia, two years. The manager of the stable is Mr. R. W. Davies, a son of the proprietor. He is one of the managers of the big Copland Brewing Company of Toronto, a young business man of the hustling stamp.

Sir H. Montagu Allan, Sir Thos. G. Shaughnessy, Mr. Bartlett MeLennan and Mr. Ogilvie are late additions to the list of Canadian owners, though some years ago the first named gentleman won the Province of Quebec Queen's Plate at the Bel Air meeting. Recent purchases by them have been made for the purpose of encouraging the sport in the Province of Quebec and to mark their appreciation of the efforts of the Montreal Jockey Club, whose splendid new track at Blue Bonnets is likely to become one of the best patronized and most popular in the Dominion.

The Hon. Adam Beck has for several years owned a few good thoroughbreds, and though his stable rarely contained more than three or four horses he has been a decidedly successful owner. The same shrewdness that characterized his purchases for horse show competition and which gained for him many notable successes both in Canada, the United States and England, also guided his turf selections, and many times he has upset the calculations of the talent by the brilliant performances of his horses, both at Woodbine and elsewhere. Unhappily four of his horses were recently burned in a railway car on their return from Woodbine. That rattling good horse Photographer was one and the others were Moorshot, a half-brother to Photographer, and a couple of two-yearolds that would have figured as entries for the King's Plate of 1910.

Charles Boyle does not race many horses now, but he has owned a host of good ones during his career as trainer and owner. The racing firm of Boyle \& Littlefield was for years one of the most important in the United States, while the name of Mr. Boyle has been for nearly forty years familiar to race goers in this country. 
The lamented death of Nathaniel Dyment, of Barrie, removed one of our most valued owners. His nephew, John Dyment, has a string of his own in training, and each season leads many winners into the paddock.

The Kirkfield stable, though not for many years established, sprang into prominence very early in its history. The Mackenzie Brothers, its owners, were lavish in their expenditure for good horses, with the result that many important races were speedily placed to their credit. The lamented death of Mr. Alex. Mackenzie it was feared might disrupt the stable, but a year later the older brother, Mr. "Rod" Mackenzie, of Winnipeg, one of the best-known horsemen in the western country and one of the pluckiest buyers that ever visited a sales-ring, decided to re-enter the game, and is gradually getting together a string of high-class horses.

Messrs. Carruthers \& Phelan are well-known Canadian owners. The former gentleman was for several years a partner of the late Alex. Shields, and their stable turned out many winners. Mr. Phelan has also been a long time in the racing game, more particularly in connection with the jumpers, and his horses also earned many winning brackets.

Irving Wheatcroft purchased about one hundred thoroughbreds within the past vear. A large number of these were sent to his island home, near Victoria, B.C., on which he has a splendidly equipped breeding farm. The remainder of his thoroughbred stock is located in Kentucky. He has a strong stable and has been a formidable competitor on the California turf. The late adverse legislation, however, in that State has ruined the racing game and has forced him to turn his attention to the eastern turf where in future, both in Canada and on the metropolitan circuit, he is likely to play a strong hand.

J. W. Taylor, also of Victoria, raced many good horses at California meetings and scored many successes. His colors will be warmly welcomed when he comes east.

George W. Cook is another popular owner, but the last two or three years his big lumber interests have so occu- 
pied his time that he has somewhat curtailed his turf operations.

Charles Millar, one learned in the law, has a warm spot in his heart for the thoroughbred, and notwithstanding the arduous claims of a great law practice, he has purchased a select string and will prove a strong addition to our list of owners. He is a winner in everything he undertakes and his racing venture is not likely to prove an exception to the rulé.

I am pleased to record the fact that $\mathrm{Mr}$. Kenneth Dawes, of Montreal, has lately joined the list of owners. His father, J. P. Dawes, was one of the best known and most popular owners of his day, both in this country and south of the border line. His horses were almost invincible in the steeplechase field, and his colors, red jacket and black cap, were for many years the most notable in cross-country racing on this side of the Atlantic.

Mrs. L. A. Livingston is one of the latest additions to the ranks of Canadian owners. She has purchased a large estate near Cobourg, in Northumberland county, and has brought over the thoroughbreds previously kept by her at Rancocas.

Gorge A. Case, a prominent real estate broker, keeps a few horses in training, steeplechasing being his favorite sport, and his colors are more often seen through the field than on the flat.

Hon. Adam Beck-

Old gold, purple sleeves and cap.

Sir H. Montagu Allan-

Dark blue and primrose, yellow stripes.

Bartlett MeLennan-

Dark blue, yellow cross sashes.

Colin Campbell-

White, cherry sleeves, cherry and white cap.

Joseph E. Seagram-

Black, yellow sash.

John Dyment-

Orange, green sleeves and cap. 
Robert Davies-

Canary and black stripes, white cap.

Valley Farm Stable-

Brown, yellow sleeves and cap.

Allan Case-

Royal blue, gray sleeves, blue cap.

Kenneth Dawes-

Cardinal, black cap.

R. J. Mackenzie-

Orange, white sash, orange and white cap.

Carruthers \& Phelan-

Crimson and white stripes, crimson sleeves and cap. Irving $\mathrm{H}$. Wheatcroft-

Cream, burnt orange collar, cuffs and cap.

G. W. Cook-

Cerise, orange sleeves, white cap.

Doane Brothers-

Tan, pale blue sleeves and cap.

A. E. Ogilvie-

Purple, red band on sleeves, red cap.

Charles Millar-

Yellow, red cap.

Mrs. L. A. Livingston-

Blue, silver braid, black cap, silver tassel.

Charles Boyle-

Black jacket, blue cap.

Sir Thomas G. Shaughnessy- .

Not registered.

Colonel Sewell-

Not registered.

Ambrose Wood-

Not registered.

J. W. Taylor-

Not registered. 


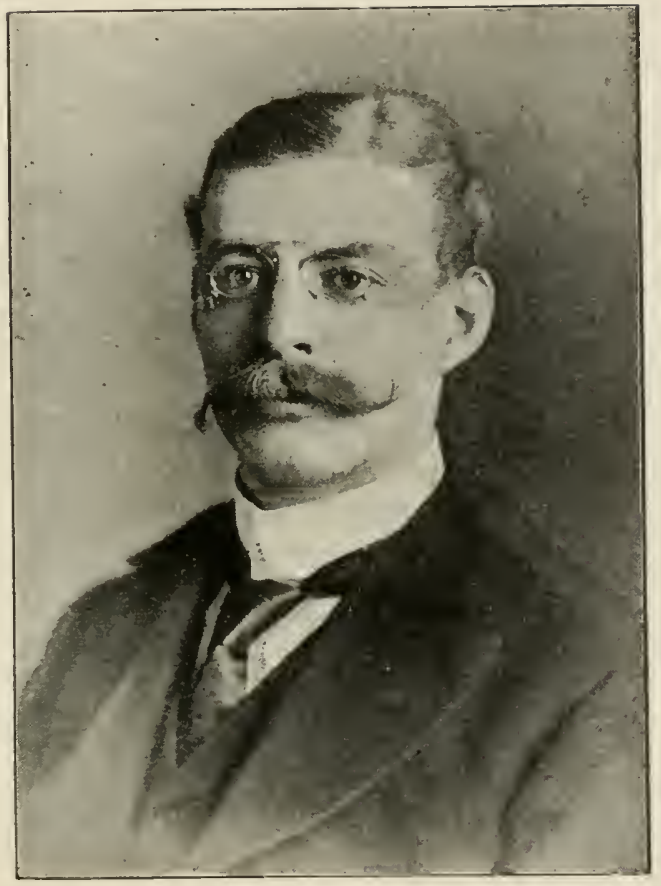

W. P. FRASER, SECY.-TREAS ONTARIO JOCKEY CLUB. 



\section{A CANADIAN BOOKMAKER'S EXPERIENCE AT SARATOGA.}

A Montreal citizen who occasionally made a "book" at local race meetings, having been fairly successful, decided to try his luck in a wider field, and chose the Saratoga meeting at which to make his debut. He had a bank roll of about $\$ 5,000$, and therefore considered himself fairly well stocked for business.

On the first race of the opening day he won $\$ 300$. On the second race he added $\$ 250$ to his original capital. On the third event he added a century and a half more to his stock and commenced to think he had found the royal road to fortune. Not being well posted on the merits of the horses engaged, he necessarily paid very close attention to the quotations hung up by other bookies. On the fourth race customers were not coming his way in any number and he decided to raise his neighbor's figures against one or two horses and see if he could not attract a little more business. Against one of the horses he raised the price from four, to five to one. As soon as he did so a neatly dressed citizen, having every appearance of a business man out for an afternoon's sport, handed up a bank bill and pointed to the horse against which he had lifted the price to five to one. Unfolding the bank note the Montreal penciller was aghast to find that it was for one thousand dollars. He mentally decided the offer was too rich for his blood, and handed it back to the stranger with the remark that it was too strong a dose. Still wearing the same pleasant smile the would-be bettor passed down the line. His name was Pittsburg Phil and the Canadian penciller, learning who it was, was willing to shake hands with himself for the wisdom he had displayed in not accepting the bet. The horse did not win and then the Montrealer concluded he lacked the necessary nerve to be a successful metropolitan operator. He did not hang up his slate the next day. 


\section{HO! THE GYPSIES.}

Of late years the gypsies have invaded Canada in considerable numbers and these restless, roaming spirits, that rarely abide in towns or cities longer than necessary to look over the horse stock or drop a hint of where the fortune tellers of their race may be found, have in some sections bred a very wholesome respect for their ability as horse traders.

I remember one of their exploits in the latter line which occurred down Kingston way a number of years ago, which proves their ability to give even a Yorkshireman a good many points and beat him. One day a string of gypsies' vans was on the road from Gananoque to Kingston, when a wealthy resident of the latter place, who was driving eastward. was strongly attracted by the appearance of a chestnut gelding with a star in forehead and two white heels, being led behind one of the vans. Having priced him, and received assurances that he was sound as a "bloomin" " sovereign and kind as a kitten, he had his own horse removed from the shafts of his dog cart and had a trial of the chestnut there and then.

The trial was quite satisfactory and as the price asked, $\$ 200$, was not unreasonable, the horse was bought and an order given his gypsy owner to call at the purchaser's office on his arrival at Kingston and collect his money. This was carried out and the horse delivered at the stable of his new owner. The following day he was hooked up for a twelve-mile drive, but became so used up before he had completed the journey that his new owner commenced to think his purchase was on the sick list. Returning to the stable with him, a vet. was called in, and it was soon made clear that the gypsies had worked off one of their specially prepared samples on the Kingstonian. He was touched in the wind, tender in the feet, 
and altogether such a patched up relic of what had once been a good hack, that his new owner was glad to sell him for sixty dollars.

About three months later the same gentleman was standing in the market square of the Limestone City when a farmer drove up a very handsome, bloodlike chestnut gelding, with not a white hair on him, hooked to a democrat wagon, in which he had a couple of baskets of butter to sell. The appearance of the horse attracted the citizen's attention, and in response to enquires as to his breeding, he was informed he was by Judge Durell, out of a mare by Jack the Barber. The breeding being exceptionally good and the looks of the gelding away above the average, an offer of $\$ 175$ was made, conditional upon the horse being a good driver, and as he showed good action when moving up and down the market square, he soon changed hands and the Kingstonian congratulated himself upon having at last secured a stylish looking good driver at a small figure. Once the horse was put to steady driving he commenced to fail very similar to the gypsy's representative, and more than one remarked that he was getting more like the other horse every day. Finally, his heels commenced to change color, and before a month had gone by it was evident that previous white marks had been painted over both in his forehead and on his feet, until one day he stood revealed as the identical horse that the gypsies had sold the same owner months before and which, after buying him back for sixty dollars, they had again succeeded, through the ingenuity of one of their brethren, who was an adept at playing the innocent farmer act, in selling the second time to the same party who had been so grievously taken in and well cooked at the first attempt. A little dye had removed the white marks and thus changed his appearance to a casual observer.

Another very good horse story had its origin through a funny circumstance that happened in Toronto some years ago. A wealthy resident of Toronto, whose pride of lineage could not be any stronger if he boasted the 
blood of all the Howards, was desirous of purchasing a pair of very superior carriage horses, and many were the teams that from time to time were driven to his mansion to be inspected. Nothing, however, came up to the desired standard of perfection, and it began to look as if the country held nothing good enough for the excruciatingly particular purchaser. At last one day two men filed an appearance, driving a pair of elegant bay geldings, black points, full 16.1 in height, matched to a hair in color; upheaded, lofty steppers, full of style and bold, speedy drivers. The price asked for the pair, $\$ 600$, was very reasonable, and the intending purchaser being satisfied on that point, commenced to ask how they were bred and who owned them.

The latter query evoked the answer that the two geldings were owned by two hackmen of this city, and as neither was rich enough to buy the other man's horse, it was decided, when opportunity offered, to put the team together and sell them. No sooner did it become known to the aristocratic gentleman that both horses had been driven by cabmen in their hacks, than he refused to purchase them at any price, and about two months later the pair were picked up by a New York buyer who paid $\$ 650$ for them.

Now for the sequel. About three months after declining to negotiate for the cabmen's pair, the gentleman in question landed in New York on his way home from a trip to England and mentioning to a Gotham friend while lunching with him at his club, that he was on the lookout for a pair of carriage horses, his friend told him of a very stylish pair that he himself had been looking at the previous day, their only fault in his eyes being that they were too big for his carriage. As size was important in the Toronto citizen's eyes, he decided to go with his friend and look them over. Arrived at the sale stable he was shown a pair of magnificent bay geldings with black points, over 16 hands high, superbly matched, thoroughly well broken and in every way a model carriage pair. The price asked was a stiffish one, $\$ 1,500$, 
but finally buyer and seller came together and in a few days the team arrived in Toronto and soon made their appearance on King street. Soon after their arrival the coachman was with them opposite a mercantile establishment, when a cab driver next to him, who was waiting for his passengers, who were shopping in the big dry goods store, asked the coachman where his master had picked up such a rattling pair of horses. When informed that they had just arrived from New York and cost $\$ 1,500$, he looked them over carefully, and finally told the coachman that he had himself offered the same team to his master for $\$ 600$ and offered to bet $\$ 50$ that such was the case. Sure enough, upon further enquiry being made, it was proven beyond a doubt that they were the pair bought here by the American buyer, and so chagrined was the aristocratic citizen over the laugh at his expense that he foolishly sold the team and pocketed a loss of several hundred dollars. Moral-Don't let your pride run away with your common sense. 


\section{HE WAS ONE OF THE RIGHT SORT.}

Poor Jack Munro! He was weighed in some years ago, but it will be many a long year before he is forgotten by those who in the ' 70 's used to be in his company at the various race meetings throughout the country.

Poor Jack had the misfortune to get a leg broken, and even after it had mended so that in the doctor's opinion our old friend might have safely trusted to it for support, he steadily refused to discard his crutches, and many a laughable incident occurred which went to show that the props might have been thrown away.

The first time our old friend's peculiarity shone conspicuously was up at Aurora. Major Peel, then a gentleman farmer, had a cosy little box on his farm a short distance north of the village. On the opening day of the inaugural meeting he gave a luncheon to a few friends at his house, and foremost among the merry-makers was Munro. For about the six hundredth and sixty-sixth time he told the story of his break, and with a face that for mournfulness would have made the fortune of a professional mute, declared he never expected to walk another step without using his crutches. No amount of fun appeared to enliven him and the unlimited amount of joking about his perpetual lease of the crutches, failed to thaw him out.

Finally Mrs. Peel proposed a stroll on the lawn, and Munro was one of the first to respond to the invitation. Jumping from the table, entirely forgetful of his crutches, he escorted our hostess to the grounds, and was soon chatting away and walking as free from lameness as any one of the party, who, as a rear guard, were following up, wondering what on earth excuse Munro would have for so soon discarding his sticks. 
At last Mrs. Peel, pretending to have just noticed the absence of his supports, warmly congratulated him on his ability to walk alone, when suddenly, as if shot, poor Jack fell against a tree near where he was standing and declared that the pain in his legs was so awful he couldn't move another step. The next moment he started on the jump for the house, grabbed his crutches, and for many at week thereafter declared he could not navigate without them. Our old friend was a good sort, fond of the sports of the turf and ever ready to back his opinion. He was one of the old guard who were "aye ready" to start, wherever the meeting might be. He had a host of friends and none who knew him but found him a thorough sportsman in the truest sense of the word. Greater praise than that no man deserves. 


\section{RILEY GRANNAN TOOK A HAND IN.}

I remember, in 1894, at Saratoga, I was walking in the company of a very prominent Canadian owner, when the well-known "Doc" Street came along. The horses were just going to the post for the next race and he gave the "eye" to my companion in such a way that it meant business. He stepped forward and the magic word whispered in his ear was "Gallilee." That bit of information was worth a good round sum to the party to whom it was given, because, if my memory serves me right, he bet either four or five hundred and got about 4 to 1 against his money. The following tells the story of the race:

The powers in control at Saratoga that year had been urged to bar Grannan from the track. The Kentucky plunger was in one of his famous winning moods and was beating the game right and left. His friends all alleged that the animus toward him was inspired by jealousy. After a time the true inwardness of the matter came out.

Street had Gallilee in a race one day. He was a legitimate 8 to 5 shot, but went back in the betting to 4 to 1 . Then Grannan went out in the paddock to see the redoubtable Doctor.

"What's the matter with your horse, Street?" querried Grannan. "He's 4 to 1 in there."

"There is nothing the matter with him," said Street. "He is all right and ought to be a favorite and should win easily. If his price is gone back somebody must have got at the boy."

The result of the conference was that Grannan agreed to bet on Gallilee if he could put up his own jockey, to which Street assented. Street complained to the stewards about his boy, had another jockey substituted- 


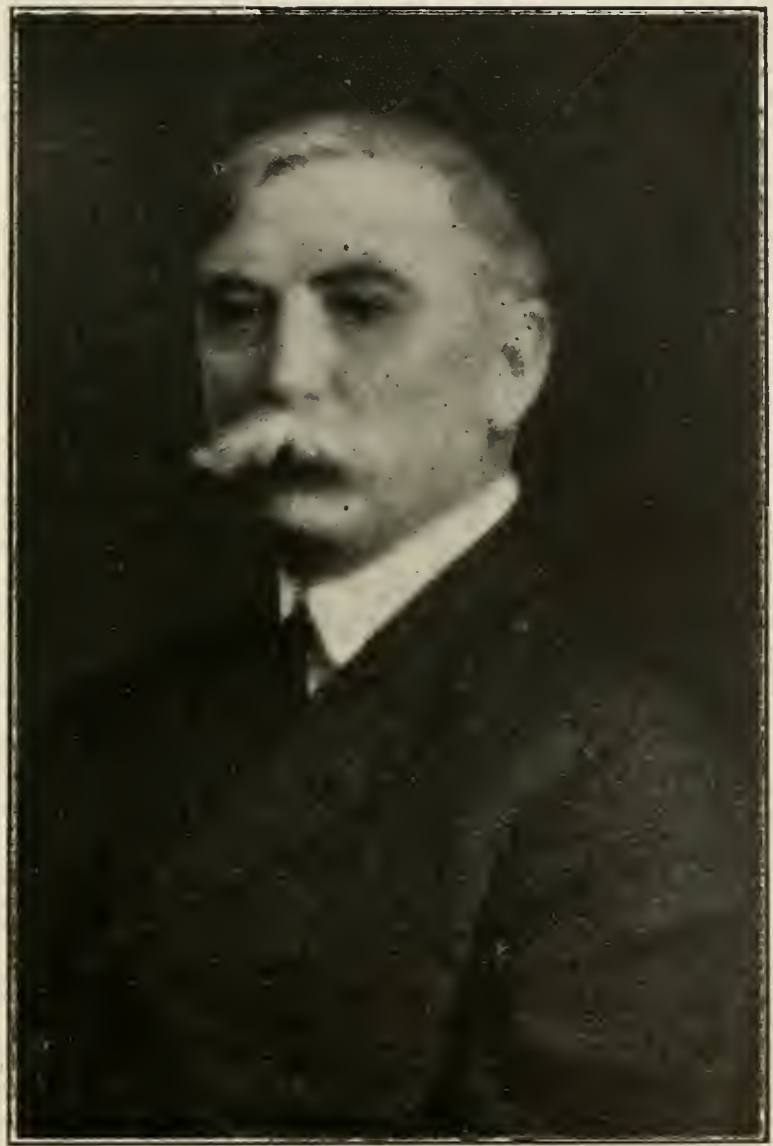

C. J. FITZGERALD, MAN.-DIR. MONTREAL JOCKEY CLUB. 

Barnes, if I remember correctly-and in the meantime Grannan rushed back to the ring and bet Gallilee to a standstill. When he got through half the slates were turned to the wall.

Grannan must have won twenty-five or thirty thousand dollars over the race. He put crimps in half a dozen bookmakers and that was said to be the reason why some people were anxious to bar him from the track, although they refrained from injudicious action of that sort. 


\section{HOW A LOBSTER STOPPED A GRAND TRUNK EXPRESS.}

It was early in the '70's that what I'm going to talk about took place and the party around whom the story centres was poor Sam Page, now deceased. At the time I speak of Quimby and Forbes were looked upon as the official pool-sellers of the country and, commencing to feel their oats, as it were, they started to dictate to the Turf Clubs and wanted everything their own way. The result was that several clubs broke loose and Sam Page was engaged to sell pools at those meetings.

One of these associations was Decker Park, Montreal, then under the control of L. W. Decker, the proprietor of the Albion Hotel, and it was arranged that Page should be on hand to sell pools in the office of the "Albion" at 8 p.m. on Monday evening, the races starting at $2 \mathrm{p} . \mathrm{m}$. on Tuesday. Now, the better to understand what follows, I will explain right here that Sam Page was one of the heartiest feeders I ever met. He was also a good judge of when dishes were properly prepared and he never allowed himself to be hurried at his meals. No matter what important business was on hand poor Sam would concentrate his whole mind on the meal before him, and no matter who waited it was utterly impossible to hurry him along.

At the time I am speaking of there was no Sunday night train to Montreal, so that it was necessary to leave on Saturday night if Page was to be on the "block" on Monday evening. I had also promised Decker to get down on the Monday, so took the Saturday night train also. Arrived at Cobourg, where was one of the chief restaurants on the road, we both went in for supper. There were very few through passengers that night and only one other person beside the conductor, Page and my- 
self, was at the table. As we sat down I noticed in front of Sam an extra fine looking lobster. It was split down the centre and certainly was a tempting morsel, and a glance at Sam's face showed that he thoroughly appreciated the look of his favorite dish and, pushing his plate to one side, he confiscated dish and lobster, and calling for vinegar, salt, cayenne pepper, mustard and oil, straightway laid himself out to mix an epicurean sauce for the toothsome shell fish. Recognizing that the schedule time for supper was only twenty minutes, I started in to hurry matters, but it was simply effort wasted. Soon the conductor left the table to get his orders, remarking as he went out that we had only a few minutes left. I shortly followed him, calling to Sam to come along or we'd leave him. Meeting the conductor on the platform, I took the lamp from his hand, opened the refreshment room door, gave a swing and a final warning of "all aboard" to the solitary feeder. It was fully five minutes behind schedule time when we pulled out from the station and we never doubted for a moment that Page was on board. I had gone forward to a front car to take a smoke with a friend, and when the conductor came through he told me that Page was not on the train. Here was a nice mixture. Pool-selling was to start at eight o'clock Monday evening and there was no chance for him to reach Montreal before 10.30 that night. Feeling certain that if he failed to keep his appointment Decker would give the job to a local applicant, I asked the conductor what chance there was of his reaching his journey's end before late Monday night. He didn't think there was any chance of his getting east of Kingston. It appeared, however, that when our train left Cobourg there was a through freight standing on the siding ready to follow us, and if Page was equal to the emergency, the conductor thought he might secure passage on it.

By the time these explanations were given we were slowing up for Grafton station, and I made a strong appeal to the conductor to try and persuade the engineer to delay matters until the freight arrived. It was a 
hard job to do it, but I finally succeeded and it wasn't many minutes before the headlight of the freight train showed some five miles up the rail. During the time I was anxiously awaiting the arrival of the freight, and speculating in my mind whether Sam would have sense enough to be on board of her, I noticed that the engine driver was very busy at some portion of the machinery that he had apparently discovered to be out of order. At last the freight train swung in on the siding, and running down towards the caboose I met Sam coming towards me puffing like a grampus, and between puffs trying to roast somebody for leaving him behind. We had been delayed eighteen minutes, and that is how a lobster stopped a Grand Trunk express. It is scarcely necessary to add that the road was then run in a very different fashion from what it is now. 


\section{THE HOME OF THE ONTARIO JOCKEY CLUB.}

The grand stand accommodation at Woodbine Park is not of the palatial order. It is, in fact, an old-fashioned structure worthy to rank with some of the ancient buildings of a similar character to be seen at long-established Fnglish race courses. Old fashioned, however, as the stand is and lacking in modern improvements, any such drawbacks are more than counterbalanced by the noble lawn accommodation in front of it and it would be diffcult to equal, much less surpass, the appearance of the building and lawns when crowded on important race days.

The steel structure on the western end of the lawn, devoted to the use of the members of the Club, is of a more modern style of architecture and is fitted with boxes which are rented each meeting to members. The flat roof of this building, sixty feet from the ground and capable of accommodating several hundred people, furnishes a superb view of the races and is always crowded when a steeplechase is in progress. The scenic view from this elevation it would be difficult to equal on any race course in the world.

The southern boundary of Woodbine Park is Lake Ontario, which is fifty miles in width at this point. On a bright day its sunlit waters, over which sailing vessels and steamers are constantly passing, adds life and animation to the scene. The city of Toronto, with its miles of business streets and tree-shaded avenues, lies to the mest, while to the north the wooded hills of Norway form an attractive background to the picture.

The property at Woodbine Park covers some eightyfive acres, with stabling for 450 horses, accommodation for several hundred more is procurable in the immediate neighborhood and is utilized by the Club at every meet- 
ing. Within the last three years the directors of the Ontario Jockey Club purchased additional property to the extent of 250 acres in Scarborough, overlooking Lake Ontario. The property is situated between the electric and Grand Trunk railways and within eight miles of the City Hall of Toronto. It is an ideal site for the future home of the Ontario Jockey Club, where one may be assured the real old-fashioned comforts of Woodbine Park will not be missing but, in addition, will be found all the modern improvements which engineering skill and practical knowledge of an up-to-date race course will suggest.

The illustrations published elsewhere portray more graphically than words the attractions of Woodbine and the great crowds that visit it. It would be difficult to find in any country a more inspiring racing picture. Its May meeting is the recognized opening event of the outdoor social season, and in the opinion of those familiar with all the leading race courses on the continent there is no place that makes quite such a brave display as that to be seen on the club house and lawn at Woodbine, especially on those days when the King's Plate and other important stake events are decided.

W. P. Fraser, Secretary-Treasurer of the O. J. C., has grown with the development of his Club. He is to-day a thoroughly well posted racing official. Prompt and fearless but thoroughly fair in his treatment of owners. $\mathrm{He}$ has for ten years filled his present position, and no more indefatigable worker was ever connected with a racing association. 


\section{THE MONTREAL JOCKEY CLUB.}

The possession of the newest and best-equipped course in the Dominion of Canada is the proud boast of the citizens of Montreal, and those who have visited Blue Bonnets and noted its perfections find it difficult to dispute the claim. Nestling at the foot of Mount Royal and occupying 167 acres of choice land, nature has done much for the superb course, but the brain of the landscape gardener has been employed and it is no stretch of the imagination to say that when all the plans under way for the beautification of the plant, some of which are as yet in embryo, shall have reached fruition, Blue Bonnets will stand comparison with any race course on the American continent.

The course is so conveniently situated that it may be reached by electric cars in twenty-five minutes from the heart of the city, or by a most excellent road, if one prefers to motor or drive; while on race days the special trains over the Canadian Pacific bring patrons within a hundred yards of the club house, the journey from Windsor station occupying only a quarter of an hour.

The track proper is one mile and an eighth in circuit and has two "chutes," one for races at a mile and the other for events at seven furlongs. The safety of the contestants and the desire that the best horse should win induced the management to make the width of the course 100 feet, and the fact that so large a percentage of favorites win over its surface is proof that the aim of those who projected the plan was accomplished.

The steeplechase course in the inner field is, in the opinion of experts, as good as can be found anywhere. There are many steeplechase enthusiasts in and around Montreal, and some of the gentlemen who occupy execu- 
tive positions in the Montreal Jockey Club have given their special attention to the construction and care of the conrse for the timber-toppers. The jumps are constructed strictly according to regulation, both as to height and thickness, and care has been exercised that the "take-off", and "landing"' places should be good, sand having' been mixed with the soil so that a horse may extend himself with safety.

The club house is an imposing structure of two stories and an attic, a combination of the French and colonial styles, capable of accommodating about 1,500 persons. It is situated on an eminence and commands a splendid view of every part of the course. In fact, spectators, whether in the galleries or on the lawn, can see every movement of the horses during the races, whether on the flat or 'cross country.

The grand stand, with a seating capacity of 3,500 , is built almost entirely of steel and concrete and it, too, is on a knoll with a lawn for spectators, which affords perfect facilities for viewing the sport. The refreshment rooms are beneath the stand and the telegraph offices are in a well beneath the stairway.

The paddock is large and conveniently placed behind the club house so that ladies who wish to look the horses over before the races may do so with comfort.

A feature of the comrse is the quarters for the officials, trainers and jockeys which are separated from the paddock, thus ensuring the privacy which is essential in the proper conduct of a race meeting. Only those who have business there are admitted to this enclosure, or to the next colonial cottage, in which the offices are located.

There are twenty stables, affording accommodation for 610 horses, and an artesian well supplies water of the purest quality, which is piped throughont the property.

The inaugural meet of the Club was opened June 4, 1907.

Two meetings are held each year, one in June, the other in September, and it is pleasant to note the fact that western Canadian owners of race horses have been liberal 


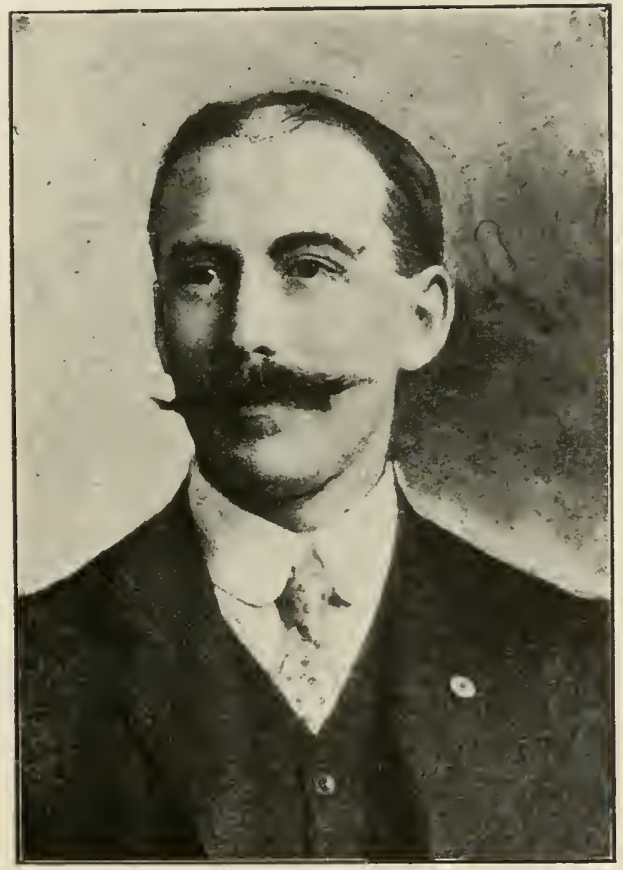

W. NORTHEY, SECY.-TREAS MONTREAL JOCKEY CLUB. 

in their support, also that many prominent American stables are always represented at Blue Bonnets.

The office holders of the Club are representative business men of the commercial metropolis. Its President, Sir Montagu Allan, enjoys a national reputation. $\mathrm{He}$ is the head of the Allan Line of ocean steamers and one of Canada's most noted captains of industry. The VicePresidents are Hon. J. E. Robidoux, Wm. P. Riggs and A. E. Ogilvie. They are ably supported on the Board of Management by the following Directors: James Carruthers, Colin Campbell, Bartlett MeLennan, Hon. J. P. B. Casgrain, Geo. R. Hooper, Hugh Paton, Hugh A. Allan, Dr. Charles McEachran, H. B. MacDougall and Welton C. Percy.

The Club's Managing Director is C. J. Fitzgerald, the well-known racing official. $\mathrm{He}$ is a Canadian by birth. For many years he was the official starter of the American Jockey Club and also manager of the Brighton Beach Racing Association. His knowledge, gained by years of experience, has been of great value to the Montreal Club.

The Secretary-Treasurer, W. Northey, is eminently qualified for the duties of his position and his evercourteous and affable manner has made him deservedly popular with the patrons of the Club. 


\section{THE WINDSOR RACING ASSOCIATION.}

The above Association occupies a prominent position. It is one of the best racing properties in Canada and its track is one of the fastest. For several years it was devoted exclusively to the harness horse, but the formation of a local jockey club, which was due largely to the enterprise of ex-Mayor Davis, introduced the thoroughbred in that section and popularized him with the sportloving public of the district.

Several successful meetings were held by the local Club, but finally a new organization was formed, the President of which is Mr. George M. Hendrie, and the Secretary and Manager, Mr. Walter O. Parmer, both thoroughly experienced racing men. Mr. Hendrie, in partnership with his elder brother, Lieut.-Col. Hon. J. S. Hendrie, of Hamilton, owns the Valley Farm racing stable, one of the most important in the Dominion. The engraving published on another page gives a good idea of the club house, paddock and grounds in connection with the Windsor track.

Within the boundary fence there are 124 acres. The stalls number 602, while immediately adjoining the track are 300 additional ones which are controlled by the Club. There are splendid water, sewer and electric light services and altogether the property deserves to be classed as one of the most complete racing plants to be found anywhere. The meetings are highly popular with the race-going public of Detroit who, in a twenty minutes' journey from their City Hall, are able to reach the track. Electric care run to the gates and big crowds are rapidly handled every day of the summer and autumn racing. A little over one hundred thousand dollars are now distributed annually in stakes and purses, and the plan adopted of paying the money won immediately the 
official decision is given, is one highly popular with owners of horses. A large amount of money is put into circulation every racing season by the presence of such an influx of horses and visitors, a fact which is appreciated by the farmers of the surrounding country as well as by the business men of Windsor.

track. Electric cars run to the gates and big crowds are

The owners of the property have made a liberal offer to the municipality to construct extensive buildings in which to hold an up-to-date County Show and additional building accommodation in which anction sales of horses and other live stock can be advantageously held. Even at the present time a good deal of stock is disposed of each year at Windsor, but with the splendid accommodation which Messrs. Hendrie and Parmer would, under reasonable conditions, be willing to supply, there could not fail to be a noteworthy increased development of the live stock business at the city of Windsor. 


\section{THE HAMILTON JOCKEY CLUB.}

The boom in turf matters in Canada has been nowhere made more apparent than in the city of Hamilton. Racing in that city was under a cloud for many years, but the establishment of the Hamilton Jockey Club secured a resurrection of the sport and its restoration to public favor. The present Club, under the Presidency of Senator the Hon. Wm. Gibson, one of our representative railway contractors, and a strong Board of Directors, has made a splendid record. Their two meetings a year are attended by large crowds, an average of eight hundred a day going by special train from Toronto. Their stakes and purses are liberal and the number of horses that race there is only limited by the stable accommodation procurable. The property is about seventy-five acres in extent. There are 490 stalls on the grounds and over one hundred additional in close proximity to the track. The latter is one mile and a sixteenth in circumference and past performances over its surface have proved it to be one of the fastest in Canada. There is also a turf course of one mile, being the only one in America, with the exception of Sheepshead Bay. The steeplechase course is one of the best to be found anywhere.

Its President, Senator Gibson, has been engaged in many notable works, such as the enlargement of the Welland Canal, the new Victoria Bridge at Montreal, the masonry of both ends of the St. Clair Tunnel, as well as the masonry in connection with the construction of the most important bridges on the Grand Trunk Railway system. He owns and operates two of the largest limestone quarries in Canada. He also holds many positions of honor and trust, amongst them being the Presidency of the Bank of Hamilton, also of the Hamilton Gas Light Co., Director of the Canada Life Assurance Co., and is 
also a director on the board of a large number of other important corporations. He is one of the most progressive members of the Senate in Canada, Chairman of its Banking and Commerce Committee, and the Hamilton Club are to be congratulated on securing him for their President.

Its Secretary, Mr. A. R. Loudon, for many years enjoyed the reputation of being one of the best gentlemen riders in this country, his forte being steeplechasing, and between the flags he was a first-class performer, possessing good judgment and plenty of nerve. As a Secretary he is popular both with his Club and the general public and is to be congratulated on the great success that has been achieved by the Association since he was installed in office. 


\section{A CANADIAN "GUERILLA" YARN.}

Some time ago when travelling in a railway carriage I chanced to meet an old "guerilla" of the road, one of the pioneers of ' 62 , in whose company at that ancient date I had journeyed many thousands of miles, when railway trains were few and far between and telegraph offices were unknown in a majority of the villages of Ontario. As we sat and chatted about ye ancient days the name of many a good fellow who has since sailed over the dark river came to mind, and pleasanter thoughts of other veterans still on the warpath whiled away in a happy fashion what otherwise might have proved tedious hours long drawn out.

One of the old-time recollections twined around as rare good a specimen as ever unpacked a sample trunk. My old friend Linton, known to his intimates as "Bob" Linton, now alas on the retired list through blindness, was one of the very earliest enlisted "guerillas" of the very select company in that ' 62 and thereabouts who had the road to themselves, and many a good trip he and I had together in those days. The fun in connection with friend Linton was scored at Mount Forest a good many years ago, and mouldy though the story be with age, it will be fresh as new paint to the present army of young men who go forth with cases and trunks from this city.

The night was one in August, close and sultry, and the bedroom which Bob had apportioned him being of the slanting roof order, was almost hot enough to stew oysters, so the occupant forthwith proceeded to elevate the window to the top notch. This done, he went to bed, not to sleep, but to roll around on top of the clothes and wonder why on earth he had been idiot enough to accept such quarters when he could have had a soft mattress on the back verandah where a cool air fanned to sleep two of his chums who had refused to be grilled in similar quarters. Soon after lying down he was disturbed by a 
fluttering noise, as of a bird flying around his bed, and springing up he struck a light and saw a small, flattened out looking object, like a compressed mouse, with wings, flying about the room. Now Bob, not being well versed in natural history, was undecided as to the character of his room-mate and, considering it a mighty queer kind of bird, he determined to catch it if possible, and examine it more closely by the morning light. So, taking his felt hat, he started on a chevey-chase, and after stubbing his toes a dozen times and knocking an inch or two of bark off his shins, he finally cornered the intruder with his hat and shut it up in a drawer of an old-fashioned table that stood near the window, after which he went to bed and fell asleep.

His sleep, however, was a brief one. He had scarcely sounded the first note on his nasal trombone, on which he was a rare good performer, when a further rushing sound awakened him, and lighting his lamp once more he succeeded in catching a second bat, but not until he had caromed with his toes on every article in the room and dropped a few cuss words as mile-stones to mark the weary journey he travelled to make the "catch." Once caught, he deposited it in the drawer with its companion and again took to bed. Soon again, however, he was awakened in a similar manner. Bats appeared not to come as single visitors, but in companies, and seven different times did Bob chase the darned little critters around that room until he had that number 'prisoned in the table drawer, to be duly flourished before his friends in the morning in evidence of his night's doings. At last the supply of bats seemad to run out, and he succeeded in getting a ferw hours' sleep. When he awoke he jumped out of bed and cautiously opened the drawer containing his victims, but, great Scott! there wasn't a bat to be found. He opened the drawer its full length, and then discovered it had no back to it. Bob had, in fact, spent two-thirds of the night catching the same bat, which had flown out of the back of the drawer about as soon as he put it in the front way. 


\section{AN OLD-TIME FORTY-MILE TROT.}

There is no getting over the fact that Canadians, as a people, are as fond of sport as their ancestors across the herring pond.

True, we have not a wealthy class that can afford to lavish its tens of thousands a year in providing sport for the gratification of the public taste, but what our citizens lack in ducats is made up in enthusiasm and you can witness as much enjoyment at a roadside race for a tendollar note as you would see on Epsom Downs when twenty thoroughbreds sweep past the winning post. I have seen our country consins shout themselves hoarse over a horse that couldn't run his mile in better than 2.10, and I have heard the same fraternity yell like a Comanchee in honor of a plug that struggled through a heat in three minutes. Women will flirt and men will sport and bet their money on the bobtail, or some other kind, and all the straight-laced exhorters that ever cried themselves hoarse in pulpit or market-place cannot talk it out. Man has a certain amount of cussedness about him and when I meet a chap fond of rolling his eyes on the upstroke and crossing his hands in orthodox shape, I put him down as being "on the make." What his particular little game may be I perhaps have to find out, but it is a thoroughbred against a poodle that he has some kind of a game in hand and is only lying low for a chance to "open out." Having thus spoken a few words of gospel truth, I jump back to my text refreshed by the digression.

The old-time trotter is apt to be considered by modern turfites an old fogy that could not trot fast enough to keep himself warm. Yet the blood of these old stagers, judiciously mated, has produced the present marvellous flyer, the measure of whose capabilities has not yet been marked upon a blackboard; still, though, the old folks couldn't 
look on at a 2.10 or .12 clip, they did have some really good sport in the days of Auld Lang Syne. I can travel over forty years myself, and sometimes anchor alongside a still older one and rejoice to hear him rum the gamut of past experiences and tell how they did things in the early days. I met not long ago an ancient who told me all about a forty-mile trot that took place on the old Don race course in the year 1847 . The old heads had for some time been disputing as to who owned the likeliest hol'se, and when one chimed in on his favorite, another would talk back about his, and so it went on until the blood warmed up to the pitch when "it's money talks" and no other argument will fill the bill.

In the year ' 47 long-distance trotting was the rage, and Mr. C. E. Romaine, then known all over the continent as "Young Canada," offered to bet a thousand dollars that his mare, The Queen, could beat Mr. James Cotton's horse, Jack on the Green, a straight trot of forty miles. The Cottonites had blood in their eyes also, and the result was a match for $\$ 2,000$ over the Don track. From the moment the match was made the feeling ran high and the partizans of each gentleman kept the pot boiling right straight along. Unfortunately for Mr. Romaine, about three weeks before the appointed time, The Queen lamed herself, and her party were down in the dumps. Her plucky owner, however, succeeded in getting a postponement for ten days on condition that the full stake of $\$ 1,000$ a side be posted and the match made p. p.

This was done, and as the mare got over her lameness speculation again became brisk, a good deal of money being put up at evens. Three days before the eventful one it commenced to rain and Jupiter Pluvius kept the sprinkler going for thirty-six straight hours. As a consequence the track on the inside was fetlock deep in mud and it became necessary to trot clear on the outside to keep away from the sticliness. As the horses were rung up for the start, the most casual observer could not fail to note the striking difference in the appearance of the two performers. The mare was a scant fifteen hands, of 
light build and, though a well-known stayer and having the foot of the horse, many doubted her ability to compass forty miles of such going as she had to face that day.

On the other hand, Mr. Cotton's horse was threequarters thoroughbred, stood sixteen hands and an inch and looked as fine as a fiddle. Mr. Romaine drove his own mare, and Mr. Tom Gillespie, of Hamilton, handled the ribbons over Jack on the Green. Just prior to the start Mr. Romaine made an even bet of $\$ 500$ with Mr. Parish, of Ogdensburg, that the race would be trotted inside of three hours and a half, but a second offer of the same gentleman's of a like amount found no takers. When the word was given, Mr. Romaine went to the front with the horse trailing in close company. Mile after mile was trotted in the same Indian-file fashion, both drivers fearing to force the pace, each determined to stick to the other. For twenty miles there was no change of position, but the previous soft footing had become terribly cut up by the horses' feet and the outside of the track was now almost as bad as nearer the rail.

On the twenty-first mile The Queen let out a link and for a time opened quite a gap on the horse, but the latter, settling into a long telling stride, again ranged up, and once more the procession was kept going. As they entered upon the thirty-ninth mile not more than two lengths separating them, the excitement bubbled over and hoth sides cheered their representatives most lustily. As they came down the home stretch and started on the fortieth and last round, wheel and wheel, each driver exerting his utmost skill, and their horses trotting together like a team, human nature had to cut loose and signify its hearty appreciation of the great struggle. " \$50 on the horse." "Put up, my hearty, and I'll go you another twenty on the top of it, just for love."

The shouting of the betting men was fast and furious, each one outvieing the other in his efforts to "get on" his favorite. Both animals showed signs of distress, and it was a toss of a copper which would quit first. At the half-mile pole the horse made his effort and gained two 
lengths in the struggle, but as they rounded the turn into the home stretch the little 'un made a last and gallant effort to re-occupy the pride of place. It was neck and neck for a brief turn, but blood and breeding told the usual tale, and after the most noteworthy long distance race ever trotted in Canada, Jack on the Green secured the verdict by two lengths, in the remarkable time, considering the state of the track, of three hours and eight minutes. The Don race course is now only a recollection of the past. Factories and workshops mark its site and the busy hum of human industry resounds where the echo of flying feet once awakened the enthusiasm of the multitude, so that the storm of their noisy acclamations vied with the murmurings of old Ontario, as her white crested waves broke on the neighboring shore. 


\section{A TROTTING MATCH IN MONTREAL IN THE '70'S.}

Along in the '70's the Albion Hotel in Montreal was a favorite stopping place with the leading horsemen, both of western and eastern Canada. Its then proprietor, L. W. Decker, was an enthusiastic admirer of the light harness horse and generally had one or two fast trotters or pacers in his stable. It was, therefore, natural for horsemen to foregather at the Albion, and many a pleasant evening was spent discussing who owned the speediest nag. Many a match, both on the ice in winter and over the turf in summer, resulted from these evening chats, and much good sport was thereby furnished the public.

One night a good-looking stranger was introduced to the select circle by Mr. Decker. He said he hailed from New Hampshire, and as he was well posted on the horse question he proved an agreeable and entertaining companion. His business was that of a travelling salesman of patent medicines and his outfit, a good-looking, crossmatched team, a black and a gray, hooked to a gorgeously decorated wagon, made an attractive appearance. $\mathrm{He}$ occasionally drove his horses single, and on more than one occasion joined some of his newly made Montreal friends in a drive out to the Back river. The black horse was his favorite single driver, and was a good stepper, though in several trials of speed on the road with local horses he had generally come out second best.

One night at the usual gathering of horsemen in the Albion, a prominent Montrealer, while extolling the quality of a new purchase he had lately made in the west, declared his willingness to make a match against any horse owned in Montreal, the stake to be $\$ 100$ or $\$ 200$ a side, and the distance, mile heats, two in three. None of the local horsemen present appearing anxious to accept 


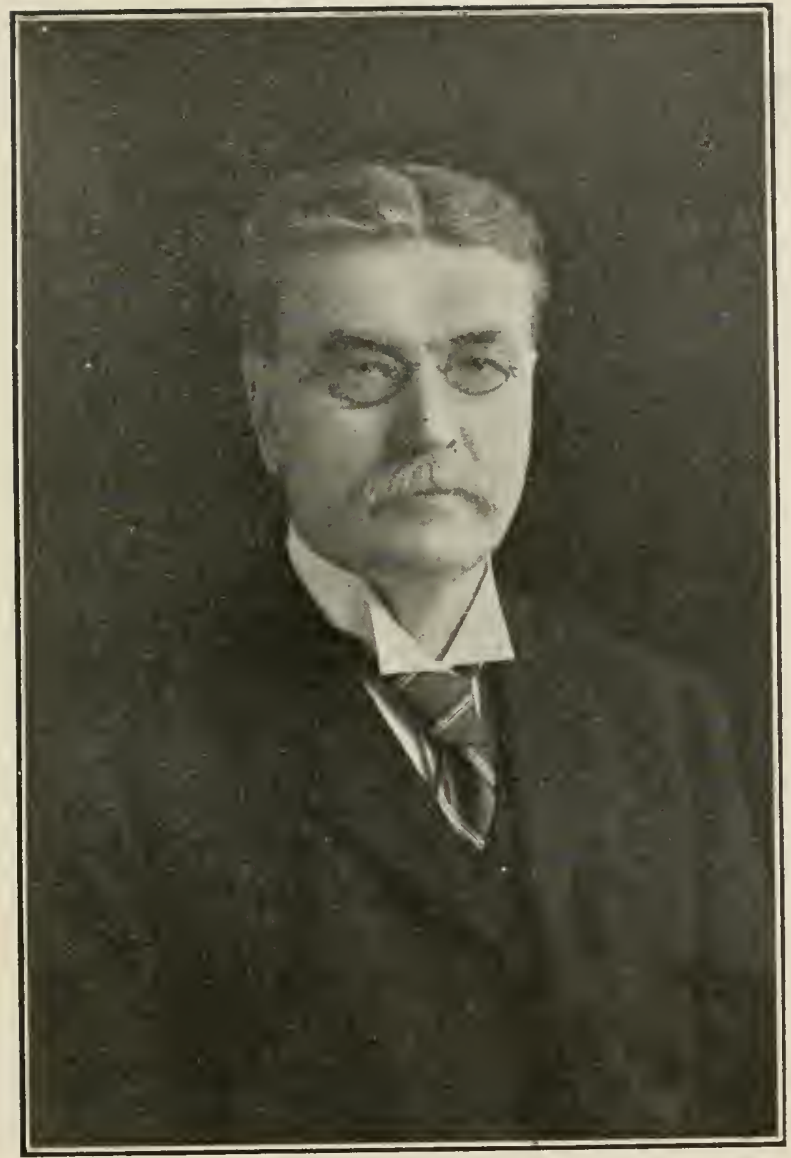

ANGUS SINCLAIR, TORONTO. 

the challenge, the patent medicine vendor expressed his willingness to take up the offer, only as he was not a resident of Montreal he did not like to interfere. He was told that he would be accepted as a citizen if he desired to take a hand in. He, however, upon being so promptly made eligible apparently backed down and allowed the evening to pass without expressing any further wish in the matter. A night or two later, most of the same persons being present, the Montreal owner of the western horse, bantered the traveller as to the speed of their respective horses. This time it resulted in a match for $\$ 200$ a side (the stranger mentioning his black horse as his representative), the match to be trotted the following week, Mr. Decker being appointed stakeholder. During the few days that intervened before the race was to be decided many wagers were made, the Montreal-owned horse being a strong favorite. The medicine man made one or two small bets on his horse, but did not appear at all anxious to put much money up on the result. On the day before the race, when matters livened up at the hotels mostly frequented by horsemen, much money was wagered.

On the day of the race a big crowd was in attendance and pool-selling on the result was brisk. The Montreal horse was a steady first choice, selling for $\$ 20$ against $\$ 10$ and $\$ 12$ for the outsider. The latter was persistently supported by a well-known Quebecker, and another person, who was a stranger to those present.

When the horses were called for the first heat the Montrealer showed up decidedly the best looker. He was a hands, and in his preliminary brush down the stretch rangey looking bay gelding, standing nearly sixteen showed considerable speed. In fact, so impressed were his backers that they eagerly snapped up every bet offered. There was very little scoring indulged in. The peddler did not appear anxious to obtain the best of the start, and at the second attempt both horses went away head and head on their journey, the local horse having the pole. There was no perceptible advantage gained by 
either during the first round of the half-mile track, but going up the back stretch on the second half-mile of the journey the local horse moved away from his opponent, and though the latter was apparently driven to the limit of his speed he was unable to close the gap and was beaten to the wire by a liberal length. There was a good deal of cheering over the result. The owner of the winning horse was a popular citizen and his friends, evidently under the belief that the money they had wagered on the result was already in their pockets, surrounded the pool-seller and cheerfully bet the odds of $\$ 20$ to $\$ 6$ that their favorite would win the race.

When the horses scored for the second heat a closeobserving Toronto horseman who had wagered $\$ 100$ on the Montreal horse, noticed that the rigging on the peddler's nag had been changed, and suspecting from this circumstance that there might be a nigger behind the woodpile, he decided to hedge his money, and this he succeeded in doing, and to keep an interest in the game he bet $\$ 30$ against a century on the Yankee horse. When the word was given in the second heat both horses started head and head. They trotted like a team the first half, and until they rounded into the home stretch at the finish of the mile, the proverbial blanket would have covered the pair. Now, however, the black horse, responding to the call of his driver, forged ahead, and though the finish was an exciting one, the stranger had the best of it by half a length. The result in the second heat cooled the ardor of local bettors and only a limited amount of business was afterwards done.

In the third and deciding heat both horses were again sent away on even terms, but, evidently determined to take no chances, the black horse was rushed to the front, and at the end of the first quarter was a length to the good. Passing the judge's stand the first half-mile he had a lead of two lengths, and though his driver slackened his efforts when finishing out the journey he came home an easy winner by about the same margin in the fastest mile of the race. 
The easy manner in which the Yankee had won the third heat, coupled with that flash of speed in the first quarter of it, was an eye-opener to the backers of the Montrealer, and some of them commenced to think that the whole game from the start had been an easy one for the stranger.

That night at the Albion the select circle of resident horsemen was informed by Mr. Decker that he had an interesting dispatch he was anxious to read to them. He had heard it rumored that the peddler intended going from Montreal to Newport in Vermont, and having an intimate friend in the hotel business down there he had wired him to look out for the peddler and post the boys to make no match against his black horse. To this his friend had wired the following reply, which he would read to them:

"L. W. Decker, Albion Hotel, Montreal.

"Warning comes too late. That slick peddler broke all the boys here a month ago. We gave him Horace Greely's advice to go west and try Montreal. Guess he has done it." 


\section{A CANADIAN FREEBOOTER.}

Yes, he was a particularly smart customer was Mr. L__ , and many a horseman around Brantford will make affidavit to that effect without a moment's hesitation. He carried a whole canful of sweet oil around with him concealed under his tongue, and when he was engaged in a ringing tour it would take more than three ordinarily sharp men on the judges' stand to spot him.

On one of his piratical trips down through Pennisylvania he took along with him a horse with a record low down in the "thirties" and, as it transpired afterwards, he started not only in the three-minute, fifty and forty-five classes, but also took a hand in two or three races at the fairs reserved for gentlemen's roadsters. My informant, who stumbled across him in Venango County, Pa., declared that Sol Smith Russell could not have improved upon L__-'s get-up and his assumption of the character of a local preacher.

He introduced himself as Brother Wilkins, a travelling local preacher, whose habitation when he was not swinging around the circle, was a few miles back from Pit Hole, and having run across a Fair bill showing a prize for road horses, why he just thought he had a pretty good smart kind of a roadster, and as a local preacher's salary wasn't a very hefty one, he just guessed he'd let the old horse take a hack at the company, and maybe he'd have luck enough to get a little bit of the prize money which would be considerable welcome. The purse was one hundred dollars, and his entry was as follows: "Joseph Wilkins, Pine Tree Hollow, b.g. Missionary, breeding, don't know."

When Mr. L_- in the character of Wilkins, of Pine Hollow, appeared on the track he was garbed in a long black coat, straight buttoned up from chin to waist, and a very clerical looking black hat on his head. Prelimin- 
ary to the horses being called up Wilkins mounted the judges' stand and expressed the hope that they would kind of help him through, as he declared: 'I'm not much of a driver, I'm afraid, and these chaps that are frisking around so in their delicate buggies, look as if they'd run over a fellow rather than go round him; however, I'm mighty hard up for a few dollars of ready money and as my horse is quite handy on the road, I thought I wouldn't be offending my conscience if I was to try and make a trifle out of his speed."

The judges assured Wilkins he should be protected in his rights and the "local preacher" went down, thanking them every step of the way for their kindness. His trap was a sort of cross between a road cart and a jumper and no fellow ever looked more awkward climbing a greasy pole than he did mounting the hybrid vehicle.

When the word was given he was sitting in such ungainly fashion some folks thought it was more likely he would fall off going around the first turn, but he didn't, and though he made a terrible mess of it jerking his mare, coming home he managed to get inside the flag and was saluted with all sorts of chaff for his awkward driving. The second heat he sat bolt upright as if screwed to the seat, and after another greenhorn finish down the stretch he succeeded in finishing fourth, two others being behind him. In the pool-selling that was briskly going on before the race and after each heat, all pools being sold on the race, the preacher's horse sold for one or two dollars, and appeared slow of sale even at that figure. In the third heat Wilkins appeared to have more confidence in himself, and though he still gave evidence of not knowing much about driving, he managed to win the heat by half a length. The fourth heat he also landed by about a length, and then the crowd began to think the stranger's horse was a mighty good one to win with such a driver up. Before the fifth heat there was a lot of money wagered, but still there did not appear to be anybody very hot to back the outsider and in pools of $\$ 25$ be only brought an average of $\$ 8$. This heat was much the same 
as the others. Half way down the stretch Wilkins had a length the best of it, he then let one of the reins drop out of his hand and only succeeded in reclaiming it after his horse had made a bad break; he, however, managed to get him levelled again, and after what the spectators termed a big lot of luck, he won the heat by a neck. When the two chaps who had gathered in all the tickets on Missionary met the latter's owner that night they divided up eleven hundred dollars of spoils, and so the game went on right down through the oil country, and when the bird had flown and the old heads commenced to investigate, they found that one of the cleverest operators that ever mounted a sulky had cooked their bacon for them in great shape. As a Meadville man said, he was a slick enough Canuck to shave a Connecticut Jew. 


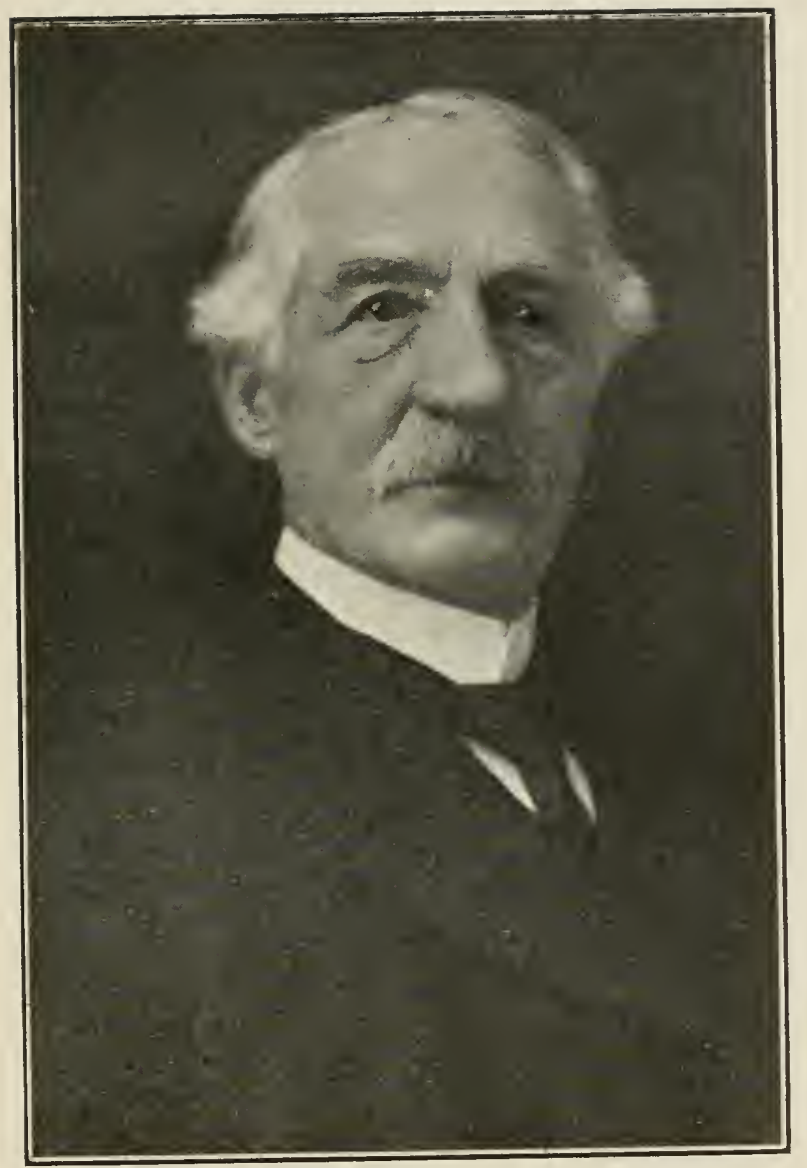

THE LATE RODDY PRINGLE. 



\section{A NOTABLE RACE ON THE ICE.}

Do I remember the Bolly Lewis race? Well, I should rather think I do. Talk about a hurricane, old chap, why the knowing ones were struck by a real old-fashioned blizzard. Their pockets were turned inside out and only that the most of them had return tickets, Toronto friends would have had to find free board for them until the spring.

Do I remember particulars of the race? Yes, I have the record clearly stamped on my memory. The way it came about was this: The present "Charley" Boyle was rusty for want of something to do, and to pass away the days and make a few dollars at the same time, he concluded to get up a winter trotting meeting. It was in 1872, a genuine old-timer, thermometer-on-a-strike, nearly all the time in the neighborhood of zero, and snow enough to let one look down his neighbor's chimney. Toronto Bay was frozen about three feet thick, and Boyle decided to make a track opposite the present Union Station. This was done, and though snowstorms came with almost daily regularity, the scrapers were kept busily at work, and when race day came round the going was $O$. K. The amount of money hung up in purses was liberal and the entries in all the classes were away above the average. The race, however, about which the speculation was briskest was the "free-for-all." There were four Canadian representatives engaged in it, and up to the day before the race nobody expected foreign competition, but at the eleventh hour the well-known trotter Bolly Lewis arrived, and so great was his reputation on the ice that the event was considered by many a foregone conclusion in his favor. How he happened to come this way is well worth recording. The eastern parties who owned him had sold him to a person in Detroit, and, according to agreement, had to deliver him there by a certain day. 
They shipped him via the Great Western Railroad, and, arriving at the Suspension Bridge, hearing that entries for the Toronto ice races closed that night, they forthwith telegraphed their entry and took the horse off the cars at Hamilton. In the meantime they telegraphed for one or two backers and prepared on their arrival in Toronto to play scoop game on the Canucks.

Quimby and Forbes were the pool-sellers, and Jim Carson's saloon was their headquarters. The day previous to the race a tall, lank Connecticut man, who drawled five minutes for every three minutes talking indulged in, had a private interview with Carson and proposed that he should do the betting for the party. Carson, no way loth to stand in on a good thing, jumped at the chance and straightway a couple of thousand dollars were handed over for betting purposes. During the afternoon he got in a little good work, and soon it was whispered around that Bolly Lewis was a sure thing and that Carson had. the straight tip. The knowing ones who just got the news also dipped in, and when the pool-box was opened at eight o'clock there was a big rush made to get on the favorite. The keen competition for first choice soon sent the odds ballooning and the call before nine o'clock was as follows:

Bolly Lewis $\$ 40$, Princess $\$ 25$, Mazeppa $\$ 5$, field $\$ 7$. At these figures Carson and his followers stood to the front and bought the choice, apparently satisfied with the chances, in fact, looking upon it as so much money picked up. Up to the hour of closing the box a large amount of money was staked and again in the morning the boys returned to the charge and set the ball rolling in the same direction. The sport was advertised to commence at 2.30 p.m., and at that hour a crowd of people numbering some thousands, was gathered on the ice. The .45 trot was a fine struggle, and the victory of Douglas was only scored after one of the most gallant efforts ever witnessed in a race. Each horse finished under the whip and the verdict in each heat only secured by a head. When the horses in the free-for-all were rung up an excited 
crowd was ranged on either side of the home stretch, and many were the opinions expressed on the probability of the foreigner distancing the whole party in the first heat. In the preparatory "overture" there were one or two old heads who did not like Lewis. To them he moved stiff and did not appear able to extend himself; but with the general run of horsemen present his past victories blinded their eyes, so that they were unable to form an unprejudiced opinion.

After a few unsuccessful attempts to get away, the word was given, with Mazeppa a half length on the lead, the favorite in second position. Trotting up the straight stretch from the judges' stand Mazeppa went like a quarter horse, and as he passed the quarter pole had fully six lengths the best of the company. Yet no glimmer of doubt disturbed the minds of the Bolly Lewis backers, and even when at the half-mile flag the yellow gelding had a lead of twenty lengths, the opinion was that the journey on the last half would anchor him. Rounding the turn, with the whole field spread out in Indian file, the leader displayed wondrous speed, and as he squared himself for home showed still more daylight between himself and his followers. Nearing the judges' stand his driver and owner, the late Simon James, pulling him up walked him past the stand in time close to 2.30. The second and third heats were a repetition of the first. Mazeppa was beyond doubt a faster horse that day than he ever showed himself, either on former or after occasions.

That day it would have taken a veritable ghost to beat him and so, no doubt, thought the eastern sharp 'uns who staked their pile on the American representative. In the pool-room that night great was the jubilee with the fielders, fifteen and twenty dollars had captured a pile, and sour were the faces of the foreigners who saw their shekels pass into the hands of those who were not likely to give them an opportunity to win them back again. 


\section{FOUR-MILE TROTTING SPIN AT OWEN SOUND.}

Away back in the ' 60 's there were not many " guerillas" on the road in Canada. Nowadays they are called commercial travellers and the woods are full of them, but at the time I am speaking about the boys could be pretty nearly counted upon one's fingers and toes, but what they lacked in numbers they made up in quality.

Branch railroads were then very scarce. The Grand Trunk and Great Western had it nearly all to themselves and great stretches of country that are now covered with a network of iron rails, could only be reached at that time on wheels in summer and runners in winter. There are lots of good men and true among the travellers of to-day, but there are also many of the other kind, which I suppose is not to be wondered at considering the big erowd there is; but in the days I am talking about a mean-acting man, such as a sneak or tale-bearer, would have been driven off the road in thirty days from the discovery of that meanness.

Then the customers, those back of the railway lines, used to hail the arrival of the "guerilla" as a happy break in the monotonous daily round. The latter generally came loaded with the latest stories and as jealousy was an article then unknown amongst country shopkeepers, they would gather of an evening with a traveller either at one of the centrally located stores or in the hotel parlor and spend a social hour in chatting and yarning. Then one of the longest driving routes, and one of the pleasantest as well, was from Guelph up to Elora and Fergus, then north through Arthur, Mount Forest, Durham and several villages lying off the centre road on to Owen Sound. There was a well-appointed stage line from the Royal City to the upper lake town belonging to the Coulson Brothers, the head of the firm being the then 
well-known J. P. Coulson, of the Coulson House at the Sound. He was a red-hot friend and an equally red-hot enemy, naturally quick-tempered and inclined to have his own way in everything. Many were the games that the "guerillas" used to put up on him just to get him started, but it was always advisable to be out of the way at the particular moment when he discovered the trick that had been played on him.

I remember one time being snow-bound at the Coulson House along with some travellers. One of these (I'll call him Jack for convenience) was passionately fond of a joke, and whether it was at his own expense or somebody else's, appeared to make no difference, so long as the laugh was on some one. He was also a bit of a horseman, would bet a few dollars in a quiet way and I believe would rather bet a "tenner" any time, even though he felt sure of losing it, than take a stump. At this particular time the four of us went driving; three of us had hired teams and drivers at Guelph, but "Jack" had brought his rig through from Brampton, and a mighty good-looking pair of bay geldings they were. At the dinner table, with J. P. in the seat of honor, we were doing yeoman service to a spread of roast partridge and stewed hare, a little special preparation which the landlord had provided on account of our being snowed up.

During the meal the talk turned upon driving horses and J. P., with his usual assertiveness, declared he had the fastest driver in the "Sound"; that he could pass anything he had ever met on the road, and though he would not bet he could beat some of the flyers that made their living on the track, he'd wager a goodly sum that he could hold his own with a liberal share of them, too. At this stage of the game Jack broke in:

"I say, J. P., you're not blowing about that flea-bitten gray out in the barn are you, with a head like a flour barrel and a pair of ears like a jack rabbit?",

At this depreciation of his favorite roadster the choleric Coulson grew several shades brighter in the face and with a look at Jack that meant mischief, broke loose: 
"Yes, Mr. Man, that's just the hoss I was talking about. He may be a flea-bitten gray in his color, but he ain't got no flour-barrel head, and his ears are as good shaped and mighty sight keener than those of some commercial travellers I've met, and what's more, he can trot faster than either one of them peacocks you are driving can run. That's what my money says, and it's the stuff that talks."

Jack listened to the outburst without a qujver, and when it was through dropped in a few more words that added kerosene to the fire, then wound up by declaring that he "did not believe that J. P. had any kind of a' good roadster to his name. That he'd seen that flea-bitten gray three summers before his present owner drew a line on him and he just thought he was of no account. Might be able to go half a mile or even a mile at a fair gait, but when it came to a five-mile drive, why, he knew he was a duffer and he wouldn't be a bit scared to trot the bay gelding in his team, if the roads were only good enough, against the gray for four or five miles fair trotting for a twenty-dollar bill and an oyster supper for the party."

This proposition by its very audacity nearly took J. P.'s breath away, but he speedily rallied and said he wouldn't accept any such soft snap, but he'd bet forty to twenty and $d-n$ the cent of a hotel bill he'd charge the whole four for the time they were snowed up in his house if he didn't make Jack think he was driving a mule before he got to the end of the four miles. The storm cleared up about three o'clock that afternoon, and by noon of the following day the Durham road was fairly well broken, and it was arranged that the parties should jog four miles down the road, then turn, and at a given signal, start for the Coulson House. A well-known resident and the writer went down to start them, and as we had a "bit" of blood between the shafts that could run like a streak, we decided to keep in the hunt as well as we were able. Arrived at the turning post it was arranged that a coin should be tossed to decide who'd have the right of the road on the start, but that in case the driver whose lot 
it was to start behind the other had speed enough to pass the leader, the latter was to forfeit the stakes if he made the slightest effort to crowd him while passing. This agreed upon the coin was flipped and J. P. won the choice. With this advantage in his favor he was determined to be generous and, turning to Jack, he offered to bet him 20 to 5 that he'd beat him fifty yards. The offer was accepted, and the writer, strengthened by Jack's confidence, expressed a willingness to take the dose a couple of times. This was done, then the word was given: "Gentlemen, are you ready? Go." And both drivers rent.

J.P. set a rattling good pace, and evidently intended to make it a hot one from start to finish, but the nose of Jack's gelding was smelling of his buffalo robe all the time and at the end of the first mile there was not a yard of daylight between them. This position was retained until within half a mile of home, and I was beginning to think that though it was a mighty close struggle my ten dollars was up salt creek, when, just as they reached the four corners, Jack drew out, yelled like an Indian on the warpath, went past J. P. as if the latter were anchored, and, sailing along with a full head of steam on, waved his adieus to his host. I was not in at the finish, for our halfbred, good bit of stuff though he was, couldn't keep the pace up with two fellows in the sleigh for four miles, but when we arrived home we heard that Jack landed a winner by three hundred yards and that when J. P. drove up to the hotel, Jack was sitting in an arm-chair outside the door, cigar in mouth, and asked him where on earth he had been fooling away his time. It was not necessary, though, for Jack to rub it in. J. P. was the sorest man in Grey county that day. It wasn't so much the money he had lost that worried him, nor the free bills for four hungry guests for five days, but he knew right well that it would take many a dollar's worth of liquid refreshment to wet the mouths of the kidders, and so it did.

But when a few days later a letter reached him from a friend down in Guelph, warning him not to be so ready 
to back his driving horse against horses with records better than .45, J. P. straightway declared that it was a "plant," and that the boys had rung in a trotter on him on purpose, and no amount of future explanation was sufficient to change his mind. When told that the gelding had been loaned to Jack for a few weeks' driving exercise, he declared it was a conspiracy and vowed he'd get even with the quartette before he quit. 


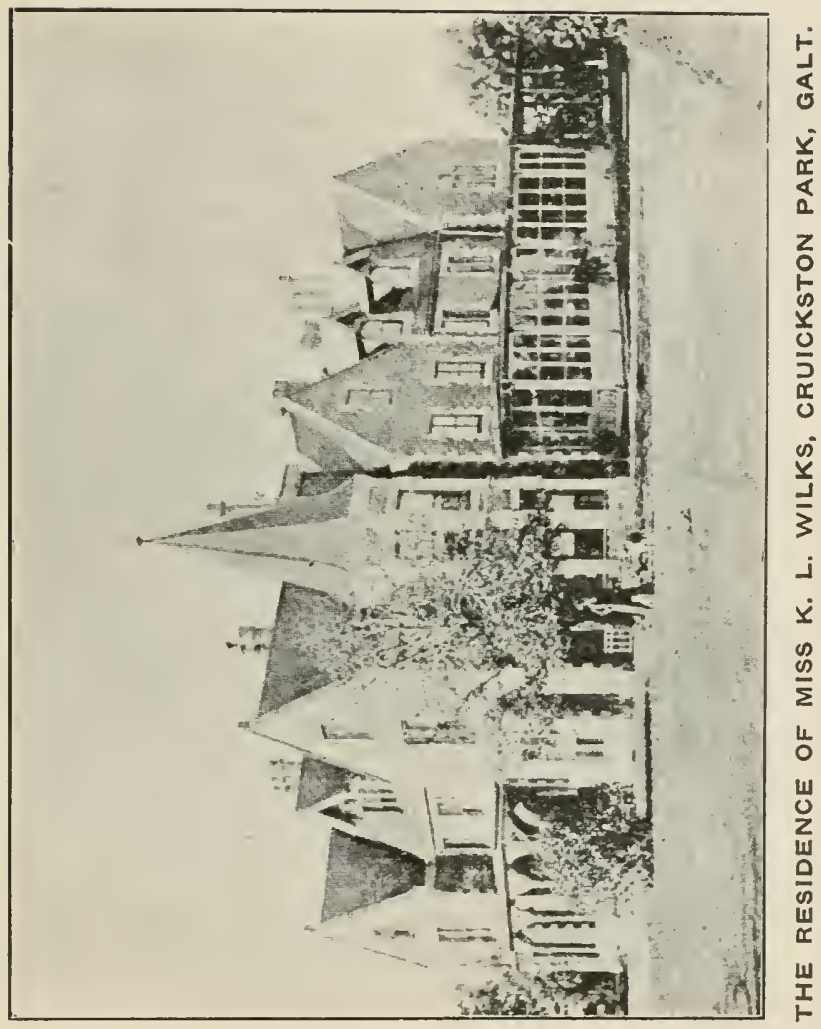





\section{MR. RILEY'S FLOATING TRACK.}

Forty years in the history of a city of the old world is but as yesterday, but forty years in the record of a young country like Canada and of a juvenile city like Toronto, is chockful of interesting events and notable transformations. Anchor yourself alongside some of the old-timers, get them started away back on the stream of life and as they come again slowly sailing towards you, the yarns some of them can spin are mighty funny ones. One of the ancients, who died in this city a short time ago, was Mr. Riley, at one time proprietor of the Revere House, at the corner of King and York streets. He was one of the oldest hotel-keepers on King street, and previous to his locating there supplied spiritual comfort in the neighborhood of the Esplanade at the foot of York street. Then, as now, the boys liked their fun and as with us, so with them, a little horse racing was relished by both old and young. In those days the swell race track was known as Boulton's track, located in the neighborhood of Beverley street, now a thoroughfare fringed with stately mansions, then a tract of ground, half bush and half a clearing. Charley Littlefield, Charley Gates, J. Mitchell, D'Arcy Boulton, of Cobourg; J. Crawford, of Port Hope, and others whose names do not occur to my mind for the moment, were the horse owners and horse trainers of that time, and many a gallant three and four-mile struggle used to be witnessed for purses nearly as large as the average nowadays. In the winter time trotting on the ice was a favorite amusement, and scores of matches would be made and settled while the snow was flying. One winter friend Riley made up his mind to distinguish himself. He waited with eager impatience for the ice to form on the bay, and as soon as nine inches of good strong material was reported, he straightway commenced preparing to 
construct a first-class mile track. A civil engineer and his assistants were engaged to do the work on scientific principles, and soon it became known and talked of both far and near as a "big thing on ice."

Every owner of a horse in the town was congratulating himself on having a high old time as soon as the track was ready, and friend Riley saw looming in the distance a big reputation for enterprise, with a fine run of customers at his hotel thrown in. A big gang of men were put to work and at the end of two weeks, on a Wednesday at noon, the track was completed and announced perfect. It was bushed every fifty yards, and altogether pronounced the greatest thing yet attempted in that line. At two o'clock a great crowd of people were on the bay taking a look at things and speculating on the grand prospects of sport ahead, and in Riley's hotel on the shore the boys were congregated getting up the programme for the races to be held. About this time a strong easterly wind blew up, the sky became overcast and the people at the track made for the shore. The storm came on so quickly that in two hours' time 'Toronto Bay was clear of ice, Riley's track, with its bushes acting as sails, swept almost intact out into the open lake, and much fun was made over the mishap. Some wags sent messages from Hamilton and Oakville that Riley's track went sailing by their respective places at the rate of ten miles an hour. The strong breeze did more than blow away the track, it blew out of friend Riley's mind all desire for speculation in that line. In his long experience as a hotel-keeper he had met with many slippery customers, but nothing in his experience came up to his track venture.

Things have changed since then. The whole aspect of the bay shore has been revolutionized, but as you sit by one of those early settlers like Mr. Riley and hear him talk of past fun, you are forced to believe that the boys of that period were as lively a lot of stags as any we have at the present time. 


\section{THE WAY THEY FOUND IT.}

I ran across an old turf follower one evening who, for convenience sake, we will call White, that being nearly the opposite color of his name, and he fell to talking about old times on the trotting turf. A friend of his owned a very speedy horse, one that could reel off three heats in .25 or better, and as the owner had no use for the horse for some months, he offered him to the yarner to campaign if he thought there was anything to be made by it.

The offer was accepted, and after a good deal of studying where to go and what class to tackle, a certain town was selected at which a two-day meeting was advertised and the .45 class was the one decided upon for the raid. The horse was dropped into the place quietly two days before the race, and on the night before his controller stepped into the pool-room to see how the betting opened out. As soon as the auctioneer started he noticed an oldtimer who had driven more ringers than any other man in the Eastern States, busy buying up all the tickets he could get hold of on a horse called "Joker." There were also two very slick veterans who were stacking up their lucre on two other nags in the same race. After the box closed, White, who knew the grizzled article that was sticking so pertinaciously to Joker, followed him out to the barn and the following was about the gist of the interview :

"I say, Pete, you are backing your horse pretty strong. D'ye think you have got a patent on the race?'"

"Hello, White, is that you? Well, I kinder reckon that I'll take the stuff when the race is over."

"Don't be too sure on that point, Pete. I don't want to scoop you, but how fast do you expect to trot over this stony and lumpy half-mile track?", 
"How fast? Well, you bet the man that leads me under the wire will have to reel off three heats mighty close to .28, or he won't get a taste of the sugar.'

In answer to this declaration White declared it was no good and if Pete wanted to save enough money to buy a plug of tobacco, he had better hedge out the money he had put in the box, for it would take a slicker gait than .28 to secure the boodle. Old Pete, however, was dead set on his ringer and was bound to sink or swim as he stood. Next day at the track there was a big crowd of people and seven horses scored for the first heat in the .45 class. When the word was given four of the seven entries rushed to the front and passed the quarter pole at less than a twenty clip. The half was clocked in 1.11, and after a fighting race of it from end to end, White's entry won the heat in 2.261/2 over a slow half-mile track. He also scored the second and third heats in .251/4 and .27. In fact, when the boys got together after the race it appeared that all four horses were raiders and each owner had struck for this particular town looking for a soft snap, and the above is the way they found it. 


\section{MY EXPERIENCE WITH A PULLER.}

In the early '70's Frank Henderson was a leading hotelkeeper in Bowmanville and was well known on the Canadian trotting and running turf. He owned several runners at different times and used to pick up quite a few races. It could not be said that his nags were top-notchers, but they came in for a share of what was going and as the owner was a plucky bettor and generally had a "roll" he eut quite a figure at the small meetings.

Henderson once owned a bay gelding called Frank and I am open to lay long odds that he was one of the very toughest, hardest pullers that ever had a bit in his mouth. He was a good-looking bay gelding about $151 / 2$ hands high and as smooth-gaited a trotter as ever wore iron. The man who handled him for Henderson was the well-known Pat Carney, as reckless a driver as ever held reins in his hands-one who would take all sorts of chances in a race and who was a terror to nervous drivers. Carney had his horse one winter exercising on the roads around Toronto and on an afternoon at the "Peacock" Hotel, on the Dundas road, kept by Robert Wilson, I met Carney, who drove up with the bay gelding. There had been a great fall of snow and it was only in the centre of the road that the going was passable. There were about a dozen of us out for a sleigh drive and one of the party proposed that we drive to Lambton Mills, a few miles further west. This was agreed to, and as I was about stepping into my cutter, between the shafts of which I was driving a smart black mare, Carney came up and suggested that I try his nag, as far as the next hotel and he would take mine. Knowing that Pat never drove a slow one, I was content to make the change, and the six started Indian file for Lambton. I was the whipper-in of the lot, but before we had gone a quarter of a mile the horse pulled so hard that it was a case of either going over the top of the chap in front or pulling out into the deep snow to get by. This I succeeded in doing and, 
despite the fact that we were plowing through two feet of untrodden snow, we went by the whole bunch as if they were standing still. Once clear, the gelding swung into the beaten road and, still pulling like an engine, kept increasing his speed. I tried by slacking on the reins to stop him, but the devil was in him and no man's arms were ever strong enough to curb his flight. Knowing well the long steep hill that led down to the brick hotel at Lambton Mills, I knew it was impossible to get down safely at the rate we were travelling. I don't believe I ever exercised so much muscle in all my life as I did during the last half-mile of that drive before reaching the hill, at the top of which was another hotel that stood back some thirty yards from the road. Just when I had decided to put my remaining strength into trying to head him for the fence, I noticed a huge drift of snow to the right and close to the hotel driving shed. There was no time for hesitation, so, putting my whole force into a sudden wrench on the right rein, I managed to head him for the drift and that ended the journey. The horse went in and was snow-bound level with his back, while the sudden halt sent me flying through space, and it took all the strength of Frank Harrison (brother of Chief Justice Harrison who lost his life while bathing in the Niagara River) to pull me out.

Carney confessed that his own arms had given out when he reached the "Peacock," and he thought he would give me a little exercise while he rested up. Henderson had a standing offer of $\$ 1,200$ from a Rochester man for the horse if he could break him of the pulling habit, but, as he afterwards told me, he cost him two sleighs, three buggies and a $\$ 40$ plate-glass window while trying to educate him. He gave it up at last and sold him for one hundred dollars to a teamster, who gave him all the pulling he wanted, hooked up with a mate in front of a wagon hauling bricks. Thus employed I saw him five years later in Bowmanville, and the sight of him brought back vividly to my mind that mad rush into the Lambton snowdrift. 


\section{AN EASTERN EQUINE WHICH FAILED TO SCORE.}

He was a big, raw-boned gray gelding; stood 16 hands $11 / 2$ inches high, and would have won a chromo in a competition for ugliness, not of temper, but for looks.

He was bred away down in the Eastern Townships in Quebec, his breeding like that of two-thirds of the trotters in the French country thirty years ago being decidedly hazy. I heard a half-dozen different horses at various times named as his sire, and he was damned more than a thousand times by those who had backed him in his races. He had won a few times in and around Montreal, and a couple of smart citizens of that burg decided to send him west and scoop in the shekels of the hayseeds. They had timed him miles better than .30, and as he was eligible for the .50 class, they simply counted up their earnings before they left home.

His Ontario debut was to be at Guelph; that was. in the days when "Billy" Bookless was one of the chief pushers in the Royal City, and when its race meetings were especially popular. It was the first day of the meeting, and Major Peel, C. I. Douglas and the writer were standing outside the "Royal" looking over the list of entries as they appeared on the programme. Seeing Repeater entered in the .50 race, and remembering that I had heard a good many ghost stories the previous year when in Montreal about this chap's phenomenal speed, I decided, after talking the matter over with my friends, to wire L. W. Decker, of Montreal, who not only knew all about the horse, but, as it afterwards turned out, owned an interest in him.

My telegram read as follows: "Gray gelding Repeater here. How fast can he trot?" About half an hour before leaving for the track the answer came back: "Good track, three heats better than .30 sure." Great Scott! what a sure thing it did look to back the eastern giraffe, and when we reached the ground and found John Quimby knocking him down for five dollars in pools of forty and 
fifty dollars, it looked such real jam that we could not resist dipping our fingers into the tempting pot. In fact, we did it many times, and when the bell sounded for the first heat in the .50 class I would not swear we hadn't figured up our winnings. In the different attempts that were made Repeater was well to the front in all of them and showed lots of speed. Finally when the word was given he shot to the front, and at the quarter pole was two lengths in the lead and going very easily. On to the half-mile pole he kept sailing, leader of the first division, and, 'pon my word, it did look just as if it was all over, bar the shouting. But just as he swung to the turn rounding into the home stretch he left his feet and then commenced a jigging business that fairly discounted anything of the sort I ever saw before or since. He literally kept bobbing up and down like a rocking horse, and when his driver did at last walk him into a trot, the horses were under the wire and the distance flag had consigned him to the obscurity of the stable. Time, 2.32.

Just about that time we wished the science of telegraphing had not been discovered, but when early the following morning he turned the track in 2.31 , we thought it would be good policy to look for our money where we had lost it and back him again in the 2.45 class to be trotted that day. We did it, and got even larger odds against our money. The first heat started in much the same style as on the preceding day. At the half-mile pole the Montrealer was three lengths on the lead, when one of those yellow curs that seem to infest a race course, ran in front of Repeater and gave him an excuse to repeat his great dance act. He did it in fine form and kept on doing it till one commenced to wonder if he wasn't anchored right there. When he reached home the distance flag had been dropped, folded up and carried to the judges' stand. Time of the heat, 2.421/2. Once more cardboard littered the green sward, and we decided that the horse that on a good track could go three heats better than .30 was perhaps a good enough nag to fool around home with, but he was of mighty little account at an Ontario meeting. 


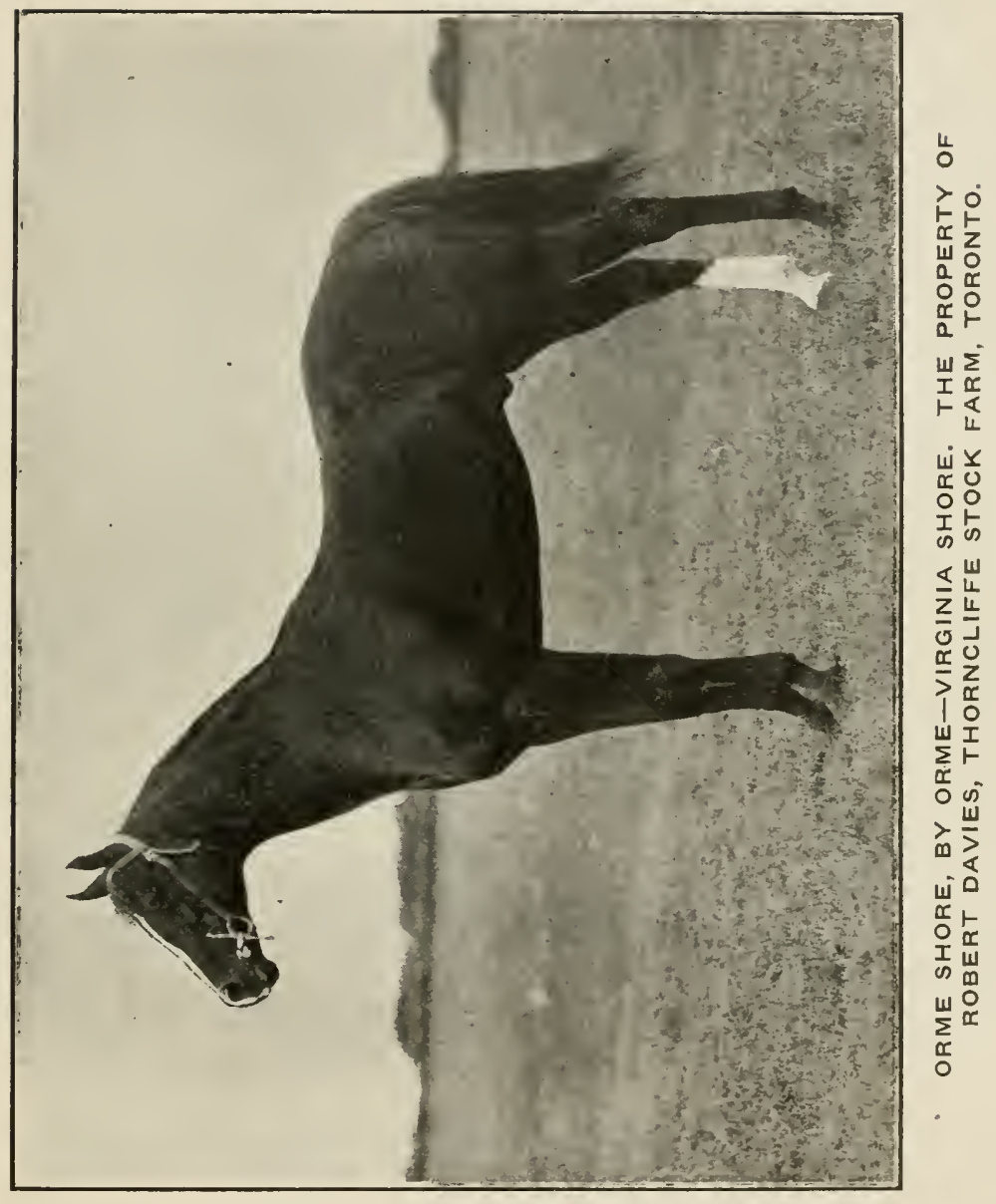





\section{TORONTO, THE GREAT HORSE MARKET OF CANADA.}

One of the most interesting and noteworthy facts in connection with the horse-breeding interests in this country, is the concentration of the trade in Toronto. Fifty years ago Grand's Repository was established in the Queen City, but it is only of late years that the business of selling horses by auction assumed noteworthy proportions. The recent purchase of the business by Messrs. Burns \& Sheppard, caused a rapid development which has kept on steadily increasing, the most substantial proof of its present proportions being the fact that a little over ten thousand horses were sold there during the past year. This army of equines included thoroughbreds, standard-breds, harness and saddle horses, Clydesdales, Hackneys and general purpose horses. The regular auction sales days are Tuesdays and Fridays, and buyers are then present from all parts of the Dominion between Halifax in the east and Dawson City in the west.

Many important winners on the Canadian running turf have been sold at The Repository, including two King's Plate winners. In the light harness horse line they have sold a host of fast trotters and pacers, ranging in speed from Maud Keswick, 2.031/4, Lady May, 2.041/4, Moth Miller, 2.07, and scores of others with records below 2.20.

Valuable importations of registered Clydesdales and Shires are sold at The Repository every year, in fact, Toronto is the admitted centre of the horse business of the Dominion. The shrewdest buyers in the country consign to this market, and the result is a constant supply of the best class of stock it is possible to procure. Quality of a high order is often represented at the sales. As much as $\$ 5,000$ has been paid for a pair and $\$ 3,500$ for a 
single horse. The firm do a purely commission business, thus in no way interfering with the interests of consignees.

Mr. C. A. Burns is the active partner, and as an auctioneer is a clever performer. He has been for years one of the representative horsemen of the province, and it would be within the mark to say that during the past fifteen years he has owned and driven for his private use more fast trotters and pacers than any other man in the country. He is a keen and critical judge of horse flesh, and this qualification has been of immense value and a powerful aid in building up the firm's great business. 


\section{THE UNEXPECTED OFTEN HAPPENS.}

All those who have done much hunting have doubtless at some time or other had similar experiences to those which $I$ am about to relate.

Partridge, or more correctly speaking, rough grouse, shooting, was always a favorite sport of mine, and many a glorious autumn day I have spent hunting the wildest and gamest bird that ever wore feathers. The whirr of his wings as he springs from the ground is of such volume as one would only expect to hear from a bird ten times his size. His marvellous cunning is displayed by the manner in which he zig-zags his course of flight, putting every possible obstruction in the way of the man behind the gun. His speed on the wing is marvellous and the man who can bring down three out of six of the birds he shoots at has a right to shake hands with himself on being a real good shot. I care not how often you may have hunted this bird, or how familiar you may be with his ways and tricks, it is impossible when one of them breaks cover at your feet not to experience a thrilling feeling of surprise.

I did not, however, start out with the intention of writing a chapter on the habits of the rough grouse, but simply to relate surprises I have experienced when hunting this magnificent game bird. There are many sections in which the grouse are fairly plentiful, but in which you have no expectation of running across big game. The unexpected, however, often happens, as the following will illustrate: On one occasion I was returning to camp after a fairly successful afternoon, having secured four brace of birds, when, in crossing a swale within half a mile of our tent, I ran almost on top of a bear. He was not thirty yards distant. He was evidently as much surprised as I was, and with a startled grunt made a dash 
for a clump of alders close by. Two barrels of No. 8 shot apparently further hastened his movements, judging by the crashing noise he made in breaking his way through the close cover.

A second experience of a similar character a year later when hunting in a locality that was fairly well settled and in which one would never expect to encounter big game, convinced me that it would be wise policy to in future be provided with two or three buckshot cartridge, but the occurrence I am now going to mention proves that even when so provided there is likely to be many a slip between the cup and the lip.

I was up in the north part of Peterboro county, where for several years I had met with good sport hunting both partridge and deer. It was a hot afternoon in October, just the sort of weather that one would expect to find partridge numerous. There was plenty of the. food these birds are so fond of, but though I had tramped many miles and hunted faithfully, a single pair was all that my game bag held. Anxious to improve matters I decided to leave the tote road, along the borders of which I had so often had good luck, and try the woods leading northwards to Blue Lake. After an hour's hard tramp with only one additional bird to reward my efforts, I decided to call it an "off" day and circle homewards. It was as hot as a July day, and by the time I got back to the tote road, I was in a humor to take matters easy for a while.

Selecting a shady spot I found a comfortable seat, and leaning my gun against the nearest tree about four feet distant, I decided to have a smoke and thus soothe my disappointment. As I was feeling for my pipe a rustling noise immediately opposite attracted my attention, and looking up $I$ was startled to see a big black bear rooting at the foot of a beech tree on the opposite side of the road and not forty feet from where I sat. There was not a breath of air stirring, and as I had not made the slightest noise he had no warning of my presence. I do not believe that $I$ ever in my life felt so chagrined as at that 
moment. Here was I within forty feet of my "Greener," the left barrel loaded with a heavy charge of buckshot and the right with Number 6 , but I knew that the slightest movement on my part would send the bear rushing into the close cover which was within six feet of him, but in less time than it takes to relate it I decided to make an attempt, and with the utmost caution stretched my arm towards the gun. Leaning as far over as possible I finally got my fingers around the barrel and still not the slightest sound by me had warned the bear of my presence, but just when I thought that bear meat and a splendid robe would crown my day's hunt, the butt of the gun slipped an inch or two, but it made sufficient noise to alarm wary Bruin who, with a grunt that could be heard an acre away, dashed into the thick brush, and though the contents of both barrels were sent after him, only a few drops of blood showed that he had been touched. I and a companion I shortly afterwards met took up the trail, but approaching twilight and a neighboring thick swamp satisfied us of the uselessness of continuing the hunt.

If it had been my good luck to have followed my usual custom when resting to hold my gun across my knees I could not have failed to score a brilliant wind-up to what had been a disappointing day.

In the deer hunting season from the first to the fifteenth of November I for several years hunted through this district, but though I and my friends had still-hunted, rifle in hand, through the big woods and swamps for miles around, we never had the good luck to meet Bruin when thoroughly prepared to properly attend to him. We often came across traces showing his presence only a few hours before our arrival, but his cunning was greater than ours, and he managed to keep out of our way. I have often read stories of encounters with bears and the pluck displayed by the hunters who killed them. I accept these stories with many grains of allowance. My own opinion, gained by many years of experience, is that the bear found in Canadian woods is a cowardly brute 
and as anxious as the most timid hunter could be to get out of the way. The only exception to this rule is the case of a wounded bear when brought to bay, or a mother when her cubs are attacked. She is then thoroughly dangerous, and the hunter who has wounded one of her youngsters and finds himself confronted by the mother requires to keep his head cool and shoot straight. Otherwise he will have a wrestling match on hand in which he is likely to come out second best.

Passionately fond of shooting and fishing, I am now, through blindness, forced to content myself with memories of past outings; of splendid sport on lakes and rivers, of noble catches of gamey bass and lordly salmon. Memory also serves up thoughts of glorious autumnal days in Canadian forests when hunting red deer or moose, and though the knowledge that such pleasures can never again be experienced, it is solace for the mind to be able to serve up some of these recollections.

Every shooting season an appalling number of accidents are annually recorded, the majority of them caused through gross carelessness in handling, or otherwise using, rifle or shotgun, and some men are so thoroughly reckless that they are unsafe companions, no matter how big the woods. At the slightest movement the gun is at their shoulder and without any proper inspection of what caused the noise, they will blaze away in the direction of the sound. Settlers often lose young stock feeding in the woods through such recklessness, and it is therefore not surprising that in some sections where they have had such experiences they object to hunters trespassing on their property.

My son, a skilful hunter and a thoroughly experienced woodsman, once had a narrow escape when still-hunting in this same section. When stepping over a log he was seen by an amateur hunter who, mistaking him for a deer, had his rifle at his shoulder ready to blaze away without further inspection. Fortunately, a lad who was steering him through the woods, detected the mistake and knocked up his rifle, thus sending the bullet harmlessly through 


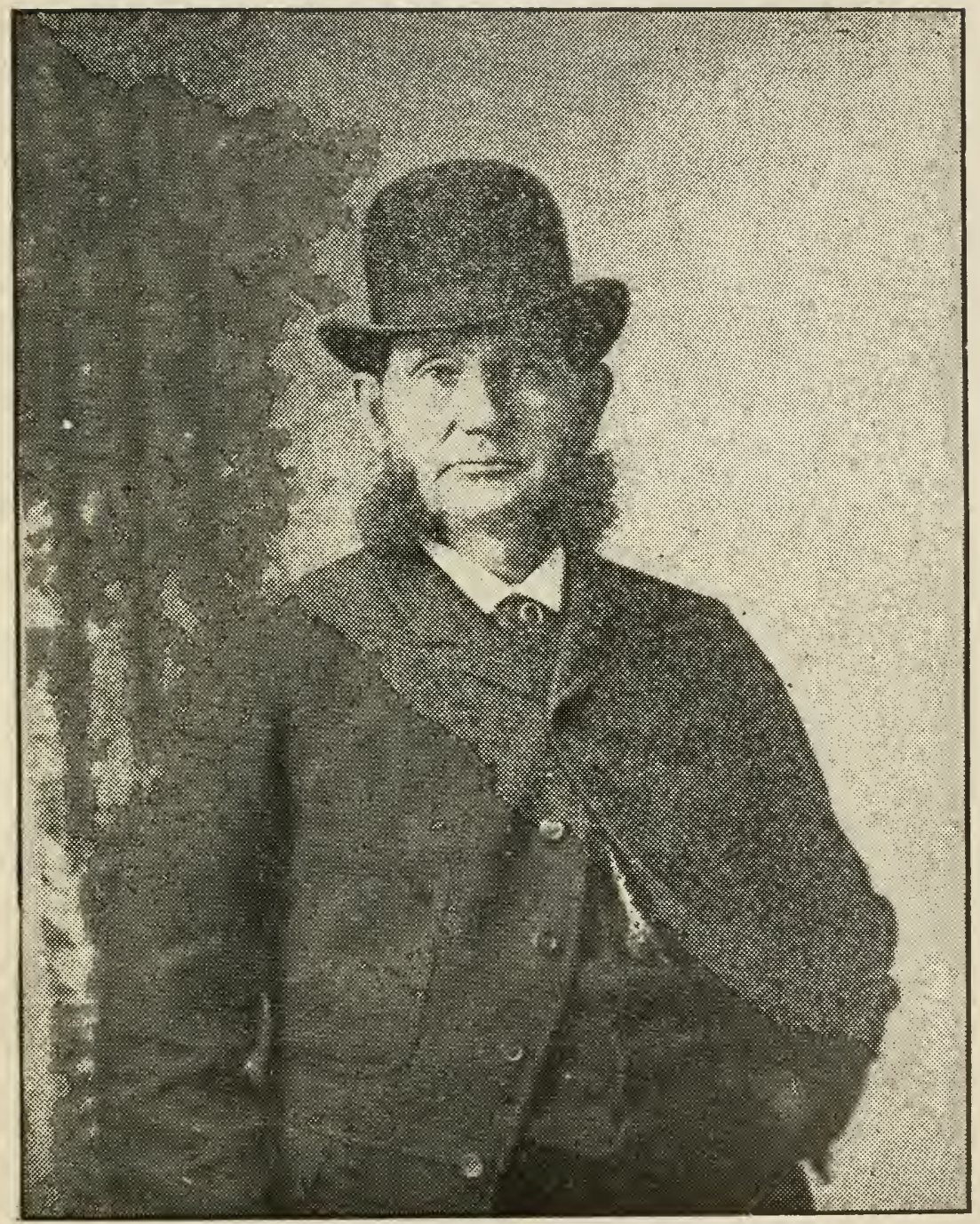

CHARLES BOYLE, THE VETERAN CANADIAN TRAINER. 

the tree tops. The reckless fool was given the balance of the day in which to clear out of that neighborhood or else take a sound thrashing. He decided to move.

I have for many years advocated the passage of a law by the Ontario Legislature, making the careless handling of firearms a criminal offence, when in so doing the life of a fellow creature is endangered. My persistent advocacy of such a measure attracted attention in an Eastern State and continued agitation by the local press on the same lines finally caused the passage of such a law by the Legislature in which, when death is the result, the person who did the shooting can be sent to prison. I am satisfied that such a law would prevent many accidents in Ontario. The law should be printed on the back of every shooting license so that there could be no possible excuse for a hunter to plead ignorance. It is a subject worthy the grave consideration of our Legislature. 


\section{A FAVORITE IDOG.}

Did you ever own a dog? Not necessarily one of aristocratic lineage, whose pedigree could be traced through a dozen generations of dogdom. Neither do I care what breed of dog he might be.

He might be a St. Bernard, a Mastiff, a Newfoundland, a Pomeranian, a Setter, a Pointer, Retriever, a Dandie Dinmont, a Bulldog, a Collie, an Irish Setter, or any other of the dozen breeds of canines. He might even be a Poodle, some kind of Spaniel or a Hound. Stop right here. I've owned all kinds of breeds and scores of them, but the best, truest, bravest, kindliest, most knowing one that ever wore hair upon a dog hide, was a hound I called Smoke.

I had heard of his mother by repute; of his father nothing was known. Smoke wore more colors on his body than were ever seen in a gypsy's shawl. He had white shoulders, a smoke-colored saddle, brownish-red ears, black band around his neck, smoke-colored spots down his front legs, black and tan down his hind ones, and a smoke and white-colored tail.

He wouldn't have taken a prize on his looks at any kennel show on the continent, but in the woods hunting rabbits, hares or deer he could ontrun, outstay and outhunt any dog I ever met with in thirty years' experience.

Other dogs would score a graud run one day-perhaps two or three days in succession. By that time their bleeding feet, shredded by the jagged rocks of the north country, had them so crippled they were knocked out for days; but no matter how sharp the granite, how steep the rocks, how thorny the underbrush, Smoke was ever on the job. I have seen him crawl out of the kennel in the morning stiff and sore in every joint, feet puffed and swollen, but you dare not leave him on his chain to rest up for the day. If you did he would protest with a voice that would be heard over half the township. 
Many a glorious run I've had with him. Talk about keenness of scent! I've known him, lying flat on the bottom of my canoe, a light blanket thrown over him to ensure his stillness, and one morning when ballasted that way, I was paddling up big Red Stone, in Haliburton district, fully a quarter of a mile from the wooded shore; suddenly the head emerged from the blanket, the nostrils quivered with excitement and I knew that Smoke had scented a deer. Cautioning him in a low whisper, I rounded a point two hundred yards to the west, quietly landed, put on his collar and entered the woods.

We had not circled more than fifty yards before his head went into the air, his whole body quivered with expectation, and had I not loosened him, he would have pulled me over the fallen log his forepaws rested on. In less than two minutes the roar that echoed over the hills told me it was a hot scent and Smoke not far behind his game. So quick was he at his work and so fast did he keep what proved to be a big fat buck on the move, that the latter, panting from his swift run, speedily circled back to the shore of the lake from which he had been driven.

He broke cover within one hundred yards of where I stood, and a lucky shot from my Winchester dropped him at the waterside. So quick had been the killing that two of the party who had been dispatched to the nearest watches had not even time to reach their stands before three shots in rapid succession warned them that the morning hunt in that direction was over, and the signal speedily brought them in.

The head of the big buck killed that November morning on the shore of big Red Stone occupies a conspicuous place on the wall of my den, and every time my eyes rest on those gracefully spread antlers and massive neck of one of the heaviest deer killed in the north woods, thoughts of Smoke creep into the mind and memory of his tragic death in the wilds of Temiscaming saddens me. Now I will tell you how it happened. 
Smoke had hunted with me in many sections of country and though at different times I owned many good hounds and hunted in company with other owners who had dogs they had reason to be proud of, yet Smoke never failed to prove his superiority. His keenness of scent, as illustrated above, was wonderful; his speed was great, his courage undaunted, and it was this latter quality that caused his death in the Temiscaming country. I was camped for a few days on the border of the Marie River, in Northern Ontario. I had gone out from the shack, leaving my rifle behind me, to examine some rock not more than two hundred yards distant. While busy breaking off some quartz, I heard Smoke's voice down near the riverside, and its sound plainly told me that he had something at bay. Fearing it to be a porcupine, one of the most miserable, exasperating creatures that infest our Canadian woods, I ran in the direction of the sound at top speed, hoping to save the dog from filling his mouth with quills. When within about fifty yards of where the dog was barking I noticed that he had treed a very big black bear. I immediately rushed back to the shack, grabbed my rifle and started for what I thought would be sure game. Before $I$ had covered half the distance there was a sudden crash and then an ominous silence. Hurrying onward I arrived at the spot to find poor Smoke literally torn to shreds. The bear had evidently seen me on my first trip and, coming down the tree, had been attacked by the dog. In close quarters there could be but one result, and the dismembered carcass showed how savage and destructive had been the work.

My companion, who had been out fishing on the river, arrived about half an hour later, and we vowed to avenge the death of the best dog that we had ever owned. Packing away sufficient food to last us for a long day's hunt we were within fifteen minutes hot on the trail. We had no difficulty in following the bear for the first hour; then the trail led us into a dense swamp. The gloom of this huge forest of cedars made it difficult to see any distance, but by cautious, careful work we gradually worked our 
way through, and after three hours of the severest kind of toil, found ourselves on a hardwood ridge and soon came upon Bruin's freshly made tracks. We followed them for another hour and then began to think it was a case of camp out for the night. Determined to move forward until we reached a high ridge to the left of where we were standing, we cautiously advanced, working our way slowly over some fallen trees, by negotiating which we would save ourselves a long detour.

My companion, who was some yards in advance of me, suddenly stopped and raised his hand in caution. I had scarcely time to note the warning signal, when, with a rush, the big brute, who was lying behind a huge log, not thirty yards away, sprang into sight, and was apparently anxious to put as much space as possible, in the shortest time, between us. His movements, however, had not been so quick as to escape the bullets of our Winchesters, and though he apparently kept moving, we knew by the labored manner in which he scrambled over some logs about forty yards away that he was badly hit. Two more bullets caught him before he hid from our view in a thick tangle of alders and not knowing how badly he was injured, and having the highest possible respect for a wounded bear, we filled up our magazines and used every possible caution in approaching him. We, however, were soon relieved from any anxiety in the matter, for when we reached the tree trunk over which he had disappeared, we found Bruin in his last struggle and a bullet at short range finished the work and with grim satisfaction we gazed upon the monster who had killed the best hound that had ever honored a camp with his presence. 


\section{CASTING BY MOONLIGHT FOR BASS.}

I suppose the average bait caster knows very little of casting by moonlight, but to my mind this is one of the most pleasurable ways of fishing. The very weirdness and uncertainty constitute its chief charm, for the more uncertain a thing, the greater the satisfaction when it is accomplished.

Confirmed fly casters often ridicule the bait caster with the stubby rod, but I have used both, and it takes fully as much skill and practice to manage the short rod as the long whippy one, and bait casting offers a much larger field and greater variety of fishing than fly casting. A surface bait should always be used, as a bass strikes at the commotion made by the bait, not because he is hungry, but merely because he wants to fight.

I have had some pleasant experiences angling by moonlight in the rapids on the Trent River below Healey Falls. I know of nothing more enjoyable on a warm evening than wading by moonlight, fly-fishing for bass. The River Trent at the point I allude to is a rushing stream of water whirling along in foam-crested ripples at the rate of seven miles per hour. The river is not more than forty yards in width and from either shore it is possible to wade out an average distance of fifteen or twenty feet without being above the hips in water, great caution, however, is necessary on account of the smooth and slippery condition of the river-bed. All of which adds to the excitement of the sport. I have fished that stream many times when the moon was temporarily obscured by a passing cloud, which made it impossible to distinguish the top of my rod, much less the line. I have hooked many a good fish when it was impossible to follow his movements beyond the occasional break of the water made in his mad plunges to avoid the tantalizing barb. 


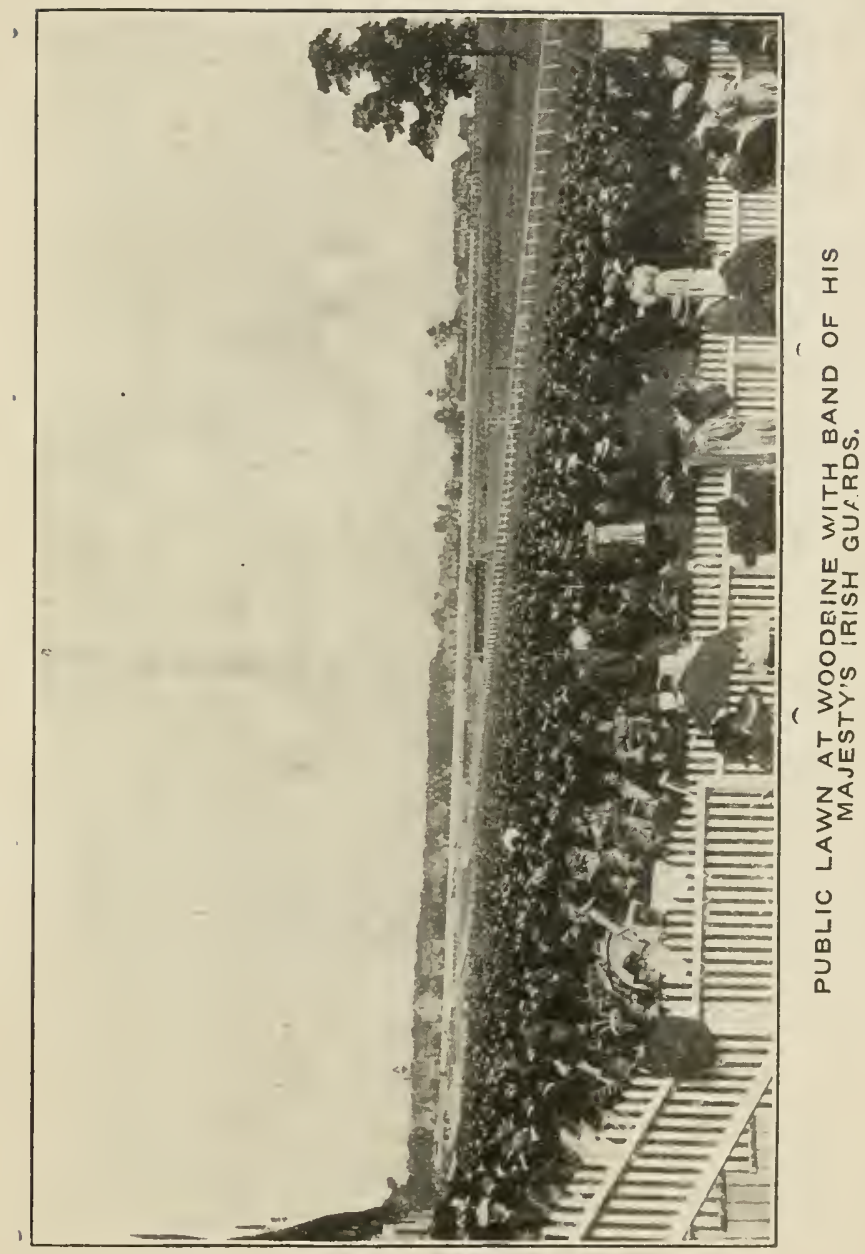



On one occasion I hooked a small monthed bass which, after landing, tipped the scale at four pounds. I had fought him for fully twenty minutes and was beginning to be as tired as the fish, when, to my dismay, a second whopper took my second fly. I looked upon the fight then as an almost hopeless one, but fortunate for me, after the first plunge, a weak spot was found and the hook taken by the fresh fish was stripped at the shank, thus enabling me to land my first captive, and I do not believe I ever felt greater pleasure in over thirty years of angling experience than I did on that moonlight night on the rocks near Healey Falls, when landing one of the pluckiest bass that ever set up a fight.

I have caught as many as two dozen green bass in the same stretch of water, running from one to two pounds in weight, in three hours' fishing by moonlight. In fact, I may say that I have caught more of that variety of the bass family in those particular waters by that style of fishing than by any other.

Not only in the Trent but in other northern waters, I have had equally good success in moonlight fishing. I remember once, on Four Mile Lake, a few miles back from Coboconk, I was anchored close to a bare rock in the centre of the lake, hoping to get a good evening catch. In this I was disappointed. It had been an excessively hot day; there was now a light, cooling breeze coming across the water, and I decided to enjoy my evening pipe in my pleasant resting place before returning to camp. About nine o'clock the moon shone out with rare brilliancy and noticing one or two breaks near to my rocky island, I determined on making an effort to catch a few fish by Luna's light. Putting one of the few live grasshoppers I had with me on the look, I cast in the direction of where I had seen the waters disturbed and was soon securely hooked to a good fighting bass. The rest of the story is easily told. With grasshopper, dew worm, and towards the last with the white miller fly, I caught nine splendid fish and was not more than one hour in doing it. The following night, with equally fav- 
orable weather, I only succeeded in landing one, but the evening before we broke camp I took five more splendid specimens in the same place and many times since then I have laid off during the heat of the day and done my fishing late in the evening by moonlight.

If any of my readers visit Old Trent I advise them to try the stretch of water I have specified, namely, below Healey Falls on the west side of the river. The banks are for the most part fringed with huge trees, which, in the moonlight cast a weird shadow over the foamcrested waves of the rapids. The moonlight streaming through the limbs of the big trees reflects in fantastic forms the waving branches of elm and birch. Here an open space reveals a path of silver in the centre of the river which looks to the eye bright as day. On either side of it the shadow of the trees creates a blackness that but brings into bolder relief the beauty of the illumined waters. There is at all times hereabouts a sufficient current of air, caused by the rushing falls, forty feet in height, just above you, to prevent annoyance from mosquitoes and night flies, and take my word for it, that the angler who once tries fly casting for bass by moonlight in the rapids of Old Trent, will be anxious to repeat the experience at the earliest possible moment. 
THE GLORIOUS NORTHLAND_THE HOME OF THE LORDLY MOOSE.

Although much has been written about this lovely Northland, nothing that has been said conveys more than a faint idea of what a sportsmen's paradise it really is.

I have canoed for hundreds of miles over its lakes and rivers, have shot the rapids of the Blanche, have fished for speckled trout in the numerous streams that empty into its waters, have shot deer and bear in the magnificent forests that skirt its shores and have seen enough moose in that country within easy travelling distance and in the highlands at the head of the river, to convince me that it is quite unnecessary for the Ontario Government to forbid the shooting of moose, excepting at intervals of years. I can speak positively on that score so far as this section is concerned. I have in a day's journey counted seventeen moose, five of them monster bulls, whose antlered heads were crowns of glory that would recompense a sportsman though he travelled a thousand miles for his game.

On my last trip to the head of the Blanche River I kept a careful tally of the moose, caribou and deer that I saw, and it totalled in one week 47 moose, 32 deer and 41 caribou. All these were seen on Ontario soil. The moose, of course, being protected by the law, were not assailable. Right here a rather ticklish question crops up and I leave it to legal minds to carp over: whether under the circumstances, if I had shot the moose I would have been subject to the law's penalties? I was out prospecting and, of course, carried my rifle with me; passing out from a gully into a clump of trees, I ran practically on top of a big bull moose. I was within fifty yards of him and it would be hard to say which was the most surprised, the bull or myself. He, however, was in fighting humor and did not propose giving me the right 
of way. His eyes blazed with wrath at an intruder upon his solitude and his bristling back hair and impatient pawing warned me that the sooner I climbed a tree the better chance I would have of living to relate the story. It did not take me long to climb well up into the nearest one, and I had just reached a safe height when his lordship favored me with a few basso profundo samples that would have been by no means pleasing music to listen to in any closer company than from this elevated perch. He walked around in a circle a good many times; pawed up quantities of earth and favored me with a lot of noise; finally, with a parting roar that boded no good to anything he ran foul of, he went away.

Now, what would the interpreters of the law have decided if I had killed this bull moose that attacked me -not I him-I could easily have killed him, but I had plenty of meat at camp and must confess I'm not partial to bull moose meat of ancient calibre. A two-year-old is as juicy a morsel as ever an epicure rolled over his tongue. It is far more palatable than the choicest venison and superior to tame beef, but it is an article that decidedly deteriorates with age, and a mature bull, like my visitor, with a spread of antlers over fifty inches, is a tough customer to grapple with, dead or alive. If you have never had an interview with a mad bull moose, then you have missed seeing a creature mad in every hair of his carcass; his eyes glitter a lurid red; his back hair rises like quills on the fretful porcupine. He is in truth a monarch of the wilds and a most impressive looker he is. The cow moose is an ungainly looking animal, but a big bull moose moving through the woods is a lordly sight. I stood one morning on a rocky point and watched a monster bull and two cows that had been disturbed by some Indians who were hunting in the neighborhood. They were coming along with that swift swinging pacing gait that will carry them a hundred miles in a day when the notion sends them off, and at the sound of the sharp whistle I greeted the leader with, he half raised his head to take a survey of the scene. It would have been a 


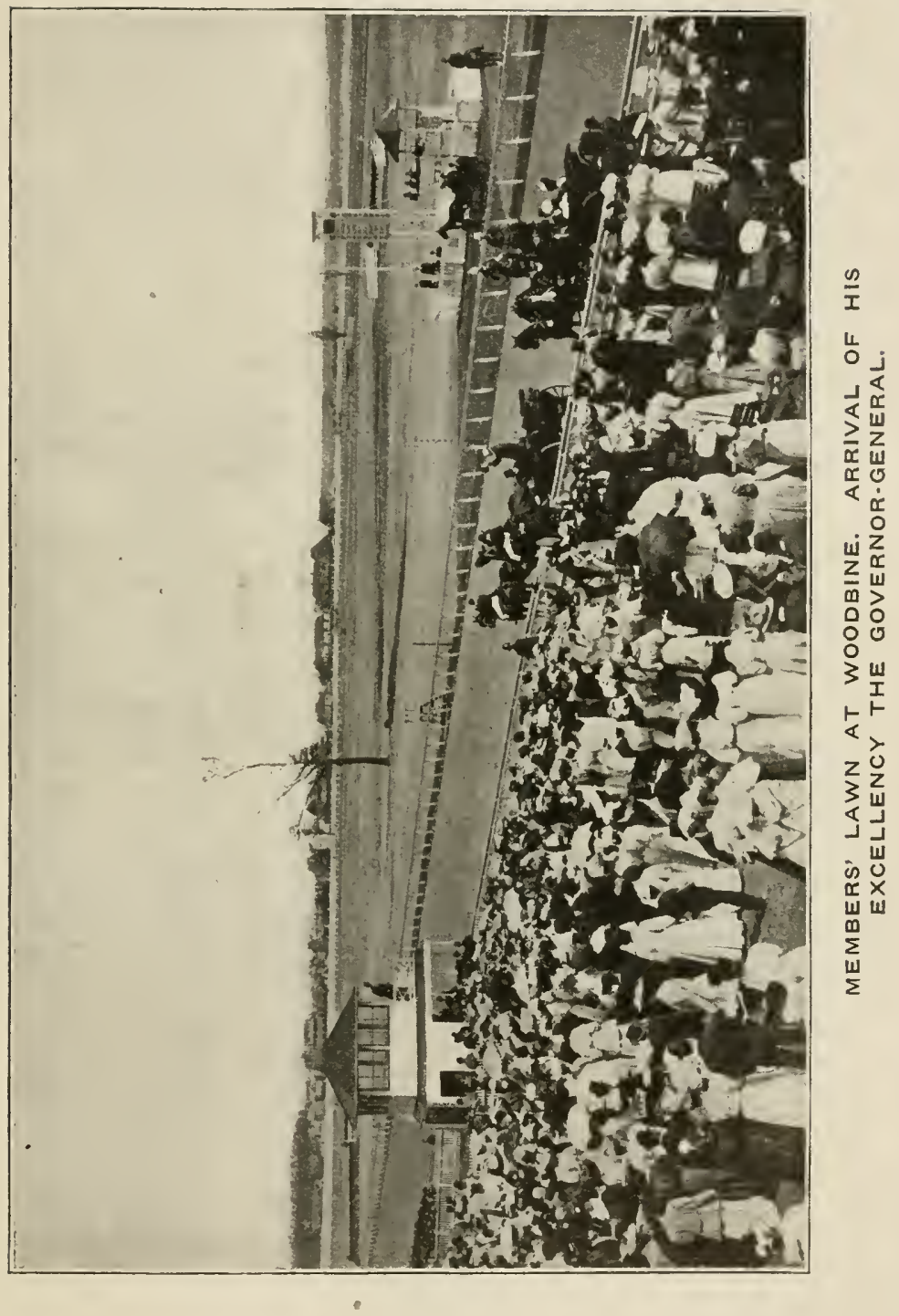



rare treat if I could have flashed a kodak on him. He was on a bit of clear ground and stood out in bold relief, his two consorts a little behind him, and a grander sight never favored a hunter's eyes.

He stood over seventeen hands high, weighed a ton or more, and had a spread of antlers that fill my eye even now, while writing this, as they did then, to the exclusion of all others I ever looked upon. It was a glorious morning in early October, a sunshiny, bright, crisp autumnal day; one of the kind that makes an outing in the Canadian forests a long dream of exquisite pleasure. The sun's rays just tipped his antlers, till they shone like burnished gold, and out of respect for his majestic bearing I doffed my cap and gave him a rousing cheer. At the sound of my voice his lordship threw his head back and struck a gait that promised many a long mile would be passed before he again halted by the way.

Round Lake, at the head of the Blanche River, is not a big sheet of water, but it is a veritable gem in the wildermess. On one-half of the shore is a dense forest, the other is a succession of rocky heights. In the lake are plenty of bass and pickerel and here, as elsewhere, in this region, partridge are fairly abundant. Moose and caribou are numerous, but red deer are not as plentiful as in the woods farther south. Straight north is Lake Abittibi, and in a direct line north of the lake is the Abittibi River, which runs clear to James Bay. In this region big game is so numerous that all the hunters likely to visit the region for a quarter of a century will make but little impression upon the number. But the sportsman who cannot spare more than two or three weeks for his outing, need not travel as far as this section to get all the shooting he desires. Much nearer the railroad, at Temiscaming station, there is a branch line running down to Keepawa on Lake Keepawa. It is scarcely necessary to add that the hunter coming to this section must have a guide. Some of the lakes are so dotted with islands and the forests so immense that until you have learned your way by experience. it would be sheer folly 
to attempt to go it alone. Your most valuable companion in the woods is first your compass and next your rifle.

The Les Quinze, or as it is generally called here, the Cass River, is in Quebec. There are fifteen rapids on it, but they are all easy to portage around. There is also a good road which runs along the river opened by the lumber company, and you can drive every yard of the way, if preferred. The fish in it are pickerel, pike and bass, and the Indians say that early in the spring they have caught 'lunge in it, but they are not numerous. Its high, rocky banks, covered with spruce and cedar, shelter plenty of partridge.

You can throw physic to the dogs in this climate and they, more wise than many people, will have none of it. The nights are cool during the hottest months of summer, and the air one breathes in these great forests is a more powerful restorative than was ever prescribed by the world's most noted physicians. You can live like a prince at a very small expense, and the man fond of his rod and gun who visits this, one of nature's grandest retreats, and feeding on the many luxuries of his skill as an angler or hunter must indeed be a chronic grumbler if he is not more than satisfied. On all the great American continent between the Atlantic and Pacific oceans, there is no territory where so much good sport can be obtained, either shooting or fishing, nor can the eye feast on such glorious scenery elsewhere as in this wonderful Northland.

It is also extremely easy to reach. The traveller journeying from anywhere in New York State, can, via Toronto, book himself to Temiscaming, via North Bay. Or, if he hails from the farther east, he books himself via the C. P. R., via Ottawa. Reliable Indian and halfbreed guides who speak English can be obtained at reasonable prices and supplies can also be purchased at several points in this country, though it is always well to take a certain quantity of necessaries with you, such as tea, coffee, condensed milk, etc. 


\section{DEER HUN'TING IN HALIBURTON.}

If I were an agriculturist on the lookout for land on which to play the role of husbandman, I don't know that I should select the district of Haliburton as the most favorable spot on which to settle. The mountains are too numerous and the bed rock is too plentiful to the acre. True, there are magnificent hardwood forests and some of this land when cleared raises fine crops, but life is too short for a man to spend the best portion of it fighting the up-hill battle against nature when it is possible to select other territory where he will not grow slabsided walking around the hillsides.

But if the country is not A No. 1 for farming purposes, there is no denying that it is a grand resort for the sportsman, and as our party was totally indifferent to the number of bushels of grain the land would grow to the acre beyond securing sufficient to feed a few hungry men for two weeks, I speak only of the Haliburton district as a country in which to find game, and due respect for my catechism days compels me to say that in this line it is worthy of high commendation. I would not recommend a man of weak lungs or tender feet to give it a go, because the chances are if he did he'd be knocked out in short order. Going across country on the half perpendicular basis is not the easiest kind of locomotion, and as there is about one mile of climbing up there for every half mile on the level, it demands sound lungs and good feet to play the pedestrian role successfully.

Again, those who go shooting up in this big northern country must be prepared to rough it, willing to go under canvas or live in some deserted lumber shanty; be satisfied with the kind of food that can be conveniently cooked with the most primitive kind of utensils and the seasoning of which has a little more wood ashes than anything else. If, however, your stomach is a strong one and satisfied 
with good sound, fat pork, venison and mountain trout as the chief dishes, with tea, minus milk, and a bed to sleep on made of three feet of cedar tips; in fact, if you are a thoroughbred sportsman, you will grow fat on these luxuries and enjoy yourself accordingly.

The morning of one 15th of October found myself and four friends snugly encamped on the north shore of the Big Redstone. The spot selected by our chief guide could not have been improved upon. It was in a narrow valley between high mountains, beautifully wooded to within thirty feet of the shore, the beach of which was of white sand, thus ensuring cleanliness around the camp. Our tent, 20 by 18, was provided with a good sized box stove, had a comfortable table made from driftwood picked up along the shore; two large logs the whole length of the tent formed at the same time a boundary for the sleeping department, outlined a central passage through the tent and made capital seats for us when we gathered around the stove at night and talked "shoot."

Our first day's work netted us two does that were in prime condition, and as the party were hungering for venison steak broiled over the coals, one of them was dedicated to camp use, and I am open to lay a corner lot to a peanut stand that the average per man of deer meat that night at supper would send a restaurant keeper into convulsions. Just how many pounds per man were stowed away I wont determine, but it was a prodigious quantity. We started in for our twelve days' hunt with the hope of averaging one deer a day, more than that we did not desire, and when I state that we shot eleven deer and about twenty-five brace of partridge, it will be seen that our expectations were realized. The quantity of venison secured enabled each one of the party to remember his friends on his return to town. One of the eleven shot was a buck that topped 300 pounds, and the noble fellow's head was crowned with a pair of antlers that for size, spread and symmetry it would be hard to match.

One day's experience was fairly illustrative of its fellows. Up at five o'clock every morning, a half hour 
devoted to a substantial breakfast of tea or coffee, trout and pork, and occasionally a hot scone as a sort of topping-off relish. Ten minutes devoted to getting our shooting irons in order, and by six o'clock at latest we were in our canoes and headed for the sections allotted to us to watch. Sometimes it was a vigil on the water and oftimes on a runway in the big woods that surround Redstone Lake. Have you ever played the sentry for a couple of hours on a runway? If you have you will swear to the correctness of what I am about to say, and if you know nothing about it you have a new experience to participate in.

I know of nothing more solemn than the stillness of the forest. I do not mean a hundred acre patch, but great woods stretching for miles and miles on three sides of you and on the fourth an arm of the lake three-quarters of a mile in width with two hundred feet of perpendicular rock guarding its opposite shore. Autumn's flaming torch has tinted every leaf but that of the evergreens, with gorgeous hues and as the light and shade play upon the waving branches, one looks upon a picture that neither ancient nor modern painter could truthfully portray without being charged with exaggeration. I looked upon maple trees that were glittering monuments of gold and silver and gems, every hue of the rainbow etched upon their leaves and each ripple of the summer-like breeze revealing new tints and gorgeous combinations of glorious coloring, until the eye became almost weary with the blaze of glory and rested itself by turning to the green of the pines and cedar.

Here you stand, rifle in hand, waiting for the sound of your hounds' musical notes, knowing that when the game is afoot, the deep roar of Leader or the tremulous vibrations of Mike's eager tongue will echo from mountain top and over valley and water. If the game heads your way, be sharp of ear and quick of eye! Bringing down a deer running at full speed from the hounds is a trick that any marksman may be satisfied with performing. True, a deer is big of body, but he is also marvellously swift 
of foot, and it demands a steady nerve and sure aim to stop a full grown buck or doe when full on the way for distant shelter; but while waiting for this crowning glory of your watch on a runway there are many things to interest you. Though for many minutes there may be absolute silence, the next moment that chattering, saucy imp of the woods, the red squirrel, will come scurrying within a few feet of the silent watcher and with tail curled over his head and paws combing his whiskers proceed to quiz you, squirrel fashion. One morning when on watch I had three mink pass within twenty feet of my stand; two large silver gray squirrels also took stock of me, and finally a horned owl, evidently dissatisfied with my intrusion, let out a shriek that would have done credit to a steam engine. More than once was I tempted to let drive at the mink, and my hands moved towards my "marlin" when I caught sight of the grave and solemn visage of $\mathrm{Mr}$. Owl taking it all in, but the distant music of the dogs bearing my way forbade any side issues, and I was forced to look on and smile serenely at the movements of my company.

The weather during our stay in camp was to the King's taste. Bright, sunshiny days, with cool, frosty nights. There was just sufficient sharpness of tone to the atmosphere to brace up the system, sharpen the appetite and make one feel that a little exercise was a goodly medicine to take. Twenty miles from the nearest post office or telegraph station-think of it! What a happy release from outside world affairs. A sort of don't care feeling takes possession of one, and you enjoy the serenity of your life, thoroughly indifferent to the state of the German Emperor's liver, or whether the Czar of Russia has sneezed a little harder than usual and thus upset the money market.

I have no doubt there are lots of people who will shrug their shoulders and say, "Not any of that in mine, thank you," and I think it is lucky for somebody else's sake that such people do not try it. I have had my peace of mind destroyed more than once by having a crank in the 


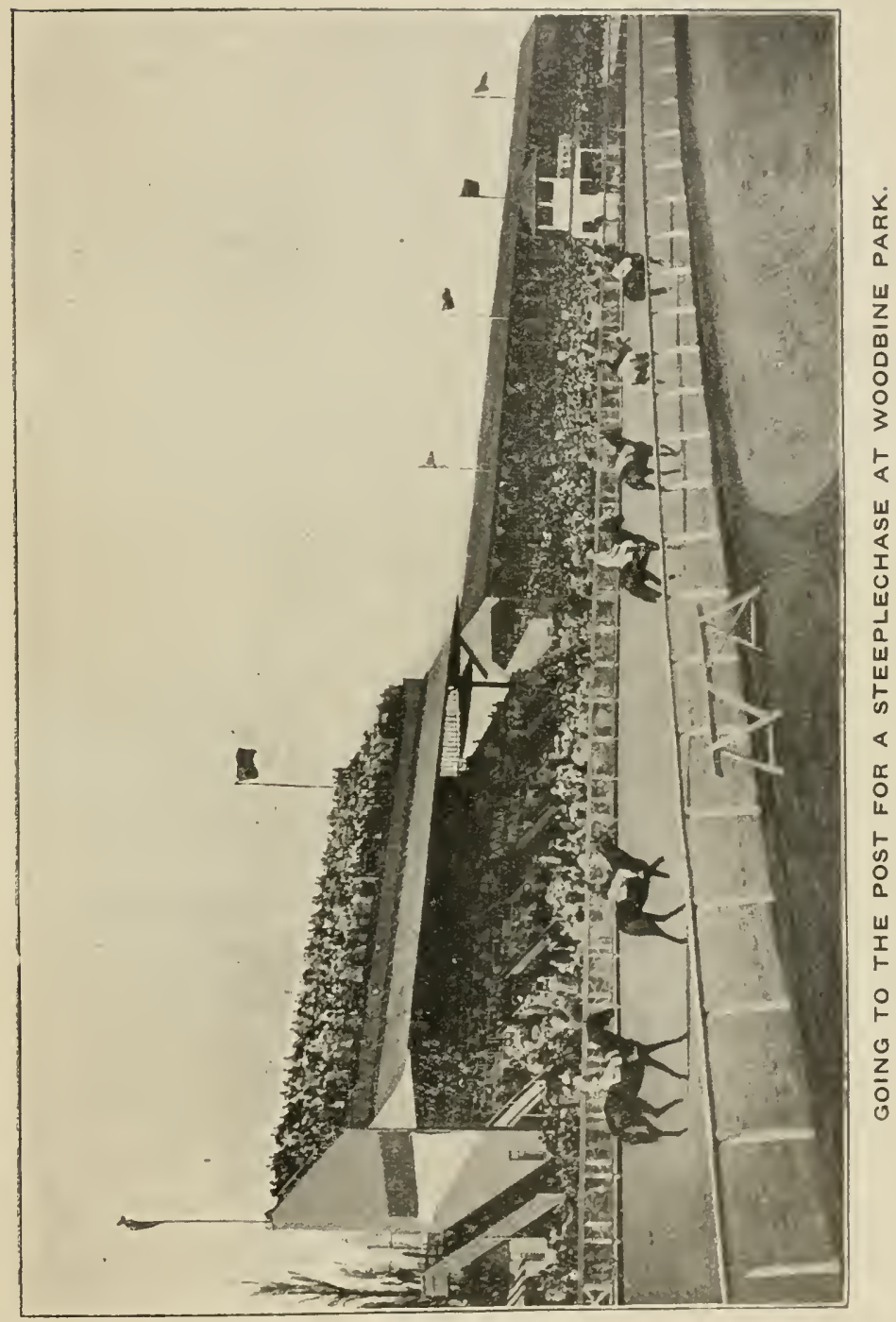



camp who wanted his meat served on a hot plate, and would raise Old Harry if his steak was not broiled to a turn. Fellows whose appetites depend on fancy fixings are a nuisance to everybody around them, and the only way to ensure the comfort of a party is to fire such a grumbler out of the camp in summary fashion. I remember once having a chap unloaded on me on a week's fishing trip that was the crossest-grained, warped and twisted, double-dyed-in-the-wool grumbler that ever burdened the earth with his presence.

He wanted more waiting on than any full-fledged French dancing master, and they are hard to overcome. He could grumble more and smile less than any sinner I have met in forty years. The first day in camp he was $\mathrm{d}-\mathrm{d}$ by the guests, and the second day the party were prepared to take desperate chances to be rid of him, and I was voted an embossed leather medal if I could drive him out. I managed it in the following fashion: The bore had casually dropped the remark that he was terribly frightened of snakes. Luckily for our peace of mind, I had that morning killed a big black water snake about four feet long, and I determined to use his mangled remains as the exterminating agent. That evening I hid it under the bed of cedar boughs on which the intruder slept, and soon after the party had retired I started telling the most horrible snake stories it was possible for the human mind to conceive. I soon had the bore in such a state that he insisted on searching the tent to ascertain if any snakes had erept in out of the cold. My friends, whom I had previously posted, pretended to dissuade him, but finally, to ease his mind, consented to humor him. We, of course, began at the part of the tent most distant from the concealed reptile, but gradually turning over the blankets and removing our valises, we worked our way round to the corner occupied by the crank. Slowly and carefully we removed the covering from the cedar boughs and as the waterproof blanket was lifted, there, sure enough, was the protruding head of a big snake. Great Scott! I'll never forget the yell that echoed in that tent. 
With a mighty bound the chap headed for the place of exit and, waiting for nothing, he burst through the curtain, breaking fastenings like cobwebs, never stopping until he reached the shore of the lake fifty yards away, where he jumped into one of the boats and swore he would row to the nearest farm-house and hire a wagon in which to reach the village. Gently and soothingly we talked with him, kindly hands were ready to help him pack his duds, willing muscle rowed him over the bay to the farmer's house, and as the rattle of the wheels that bore him away sounded o'er the waters, we returned our cordial thanks to Mr. Snake for the noble service he had rendered us. When you are afflicted with a bore in camp find out if he's afraid of snakes.

But to thoroughly enjoy such a trip as ours you must be well provided with the right kind of guides, and in this respect we were wonderfully well served. Ours had an extended reputation and proved himself a thoroughly good man. His assistants were two of the most obliging and best workers that I ever hired. Thoroughly sober men and keen hunters, always ready when wanted and no labor was considered too great by either if by undertaking it they thought they could add to the enjoyment of the party. To see them elevate a canoe to their shoulders and climb a rock at an elevation of 45 degrees to make the portage to another lake, was a revelation, and the whole work was accomplished without any fuss, in a matter-of-fact way that added to the party's appreciation of their services and around camp they were as willing workers as in the woods or at the paddle. 


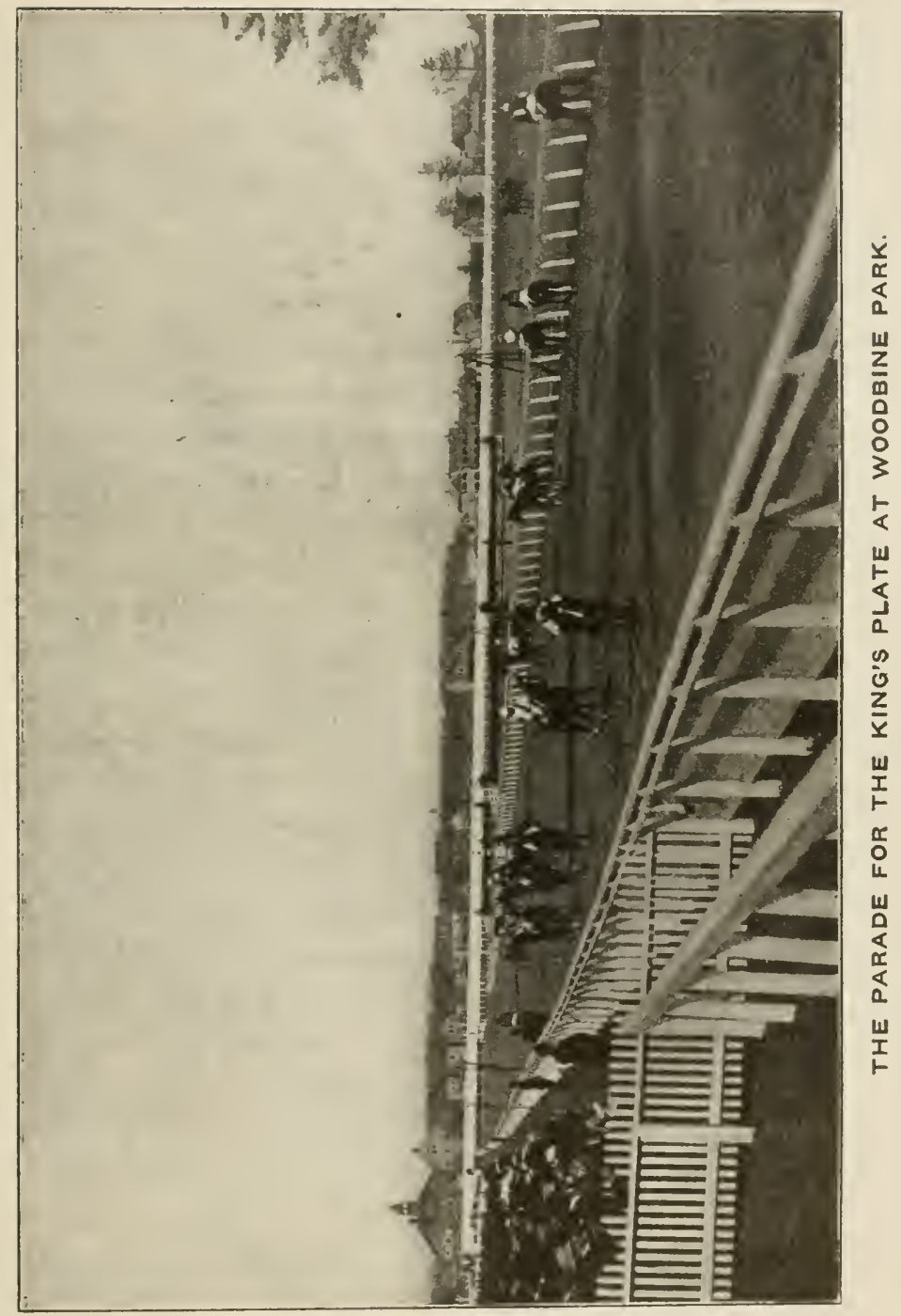





\section{A FEW SUGGESTIONS AND RECOLLECTIONS.}

Look to your rods, reels and lines; go over the latter with jealous care, because if there is one thing in the world of sport more tantalizing than another, it is to find out the weak spot when you are reeling in a fine trout or bass. Though you be a devout church member, or even a Sunday School teacher, you are apt, when such a catastrophe occurs, to say naughty words that at other and less provoking times would send a shudder through your anatomy from heels to head.

Were you ever in such a fix yourself? If you haven't been then you never have been tempted and don't know what power of mind is necessary to withstand the temptation. I was once bait-fishing a stream up in Grey, alongside a distinguished member of the Methodist Church and one of its most devoted class teachers-a man of generous impulses and a real good sort, one of the kind who believed in legitimate sport and was fond both of the rod and gun. On the occasion referred to he had hooked an extra big trout and was exercising all the arts of the skilled angler to land the fish. He had worked with him for fully twenty minutes, and at last had him well spent and was gently reeling him in. Just then another big fish jumped close beside the captive, and his splash seemed to give a hidden link of strength to the one that was being taken in out of the wet, for he suddenly swerved, and though the tension was but for a second, the line parted near the tip and about thirty feet of the silken strand, with leader attached, all went down stream.

Inspection showed the weak spot in the line. It had been put away the previous antumn without being thoroughly dried out and oiled, hence the dire result which elicited from my companion the quaint remark: "If I wasn't a churchman, I'll be damned if I wouldn't swear," 
and then quick as a flash he tumbled to the language he had used and joined me in a hearty laugh over the involuntary explosion. If you are a follower of old Ike of revered memory, don't run any such risk. Examine every. inch of every yard and test it before you leave on your trip. Look to it also that the moths have not invaded your fly-book and played havoc with your choicest samples.

Anything that has a suspicious look about it discard. Eternal vigilance is the price you have to pay if you wish a perfect outfit. Then the joy is yours of knowing that if a two, three or four-pounder gives you the slip, it was not through defective tackle, but simply because your skill was not a match for his cunning, or else, perchance, he had not been hungry enough to take a firm hold.

One of the cleverest and most popular doctors that practiced in Toronto a quarter of a century ago, a man of wonderful ability in his profession and possessing a magnetic personality, was also an enthusiastic angler, but of all the men I ever knew he was the most forgetful that ever handled a rod. One time he was up with me at Flesherton in Grey county, and, mindful of his treacherous memory, I warned him as we were about getting into the conveyance that was to take us to the river, to look over his belongings and see that everything was there. Like most men with his failing, he asserted he never forgot anything. We drove a distance of thirteen miles, and when we reached the river bank and commenced to prepare for the work in hand, the doctor discovered he had come away from the hotel without his rod. On the following day, while we were fishing the pond at Purdy's Mills, it was decided to divide the party and fish both sides of the pond and fish the river also for half a mile up both the east and west banks. Just as I reached the first bluff and had worked my way down to a convenient ledge from which to reach a very promising looking pool, the roctor hailed me from the west side with the declaration that he had left his book of hooks down at the mill and having broken the one attached to his line, was badly 
knocked out. It was a case of walking nearly a mile over very bad going back to the mill unless I could relieve him, and this was finally accomplished by fastening two or three hooks to a stone and throwing the same across the river. The Doctor then had fair luck, and when we decided to turn back had fourteen good-sized fish in his creel. Half way back he sat down on an overhanging ledge to reach a very enticing-looking spot and then, better to accomplish the leaning over act, he took his basket off and placed it on a ledge near him. Not succeeding in landing a fish at the promising looking pool, he continued his way, and when he met me at the mill was in high glee over his good luck. When I asked for the proof the doctor reached for his basket, and the look on his face when he discovered it was not there was ludicrous in the extreme. His carelessness cost him a half-mile climb over the rocks, the journey no way lightened by the voices that sounded in his ears: "Oh, Doc, you never forget anything." Poor Dr. John Kennedy has crossed another river since then, and it is one from which there is no return; he has joined the silent majority. He was a bighearted man, a generous soul if there ever was one and his reputation in his profession was not excelled by any practitioner in Canada. . 


\section{A TRUE FISHING STORY.}

A prominent resident of Toronto, half a century ago, was Colonel O'Hara, a retired British Army officer. He was a thorough all round sportsman, and his favorite pastime was fishing. There were few streams between Lake Ontario and the northern lakes which he had not sampled and but few men were as skilful as he with rod and fly. The following story told me about the Colonel is worth repeating:

A brother officer who had served in the same regiment was visiting in this country and as he was also an enthusiastic disciple of Isaac Walton the Colonel invited him to join in some of his fishing trips. The offer was accepted and the two veterans had many days of splendid sport in the streams north of Toronto. One day they were fishing near Priceville, in Grey county. The weather was sultry and the mosquitoes were out in battalions. The fishing, however, was good and the Colonel was satisfied to suffer the attacks of the pests. Not so the Major, who was waving his arms to drive off the skeeters and in doing so did more splashing of the water than was allowable. The Colonel stood it for a while, but finally his patience was exhausted and he called out: "Major, what is the matter with you this morning? You are making as much noise as if you were fishing with a sinker and float. Surely you are not demoralized by a few flies?" The remark nettled the Major, whose temper and liver had not been improved by a twenty years' residence in India, so he answered with some warmth: "Colonel, I can stand these d- flies as well as you or any other man, and you can take up the challenge if you want to." After a few peppery words a bet of a basket of "fiz" was made, the wine to be used during their outings, and the test decided upon was as follows: after 
dinner that evening both anglers were to bare their backs and go outside their tent and lie down on the grass. Smoking was allowed, but the first man to move a hand to brush off a mosquito would lose the bet, the referee being the Colonel's valet.

At eight o'clock both gentlemen stripped to the waist, and stepping outside the tent lay down side by side, both puffing vigorously at their Havanas. The mosquitoes were there in swarms that night, and the two well-fed backs were a feast they were not slow in alighting upon. Both victims commenced to wriggle and squirm, but the conditions of the match prevented the use of the hands and so no relief was possible from that quarter. The attacks at last became so persistent that the Colonel besan to weaken and regretted having badgered his friend into the game. At last the Colonel, unable to stand the pressure, slyly taking his cigar from his lips, gently pressed the lighted end on the Major's back. With a yell that might have been heard acres away the Major jumped to his feet shouting: "Colonel, the bet is off; gallinippers are barred, mosquitoes only were to count." Both gentlemen returned to the tent, and the valet was kept busy applying a sootling lotion to their backs.

It was not until the pain of the scars had been relieved that the Colonel admitted the trick he had played. The wine, of course, was supplied by the perpetrator of the joke, and many a laugh was indulged in in after days by the Colonel and his friends over the gallinipper episode. 


\section{DID THE PIRDS REASON IT OUT?}

A few years ago I did a good deal of fishing on Round Lake, a sheet of water about two miles in length by from half to three-quarters in width, situated four miles north of Havelock, on the Quebec division of the C. P. R. The lake was then surrounded by a heavy growth of timber, much of which has since been cleared off, and the destruction of the timber has practically ruined fishing in that water. The North River empties into this lake, and it was on its western shore that the circumstance I am relating took place.

A pair of fish hawks of the largest variety had for several years nested in a huge blasted pine standing in the drowned land about fifty yards back from the river. These hawks were most voracious fish destroyers and one or two visits to the neighborhood of their nest revealed bushels of fish bones, bearing ample testimony to their destructive capacity. It was finally decided that in the interest of anglers visiting the lake it would be well to destroy the birds. Many were the ingenious devices planned to effect this purpose, but during the two summers that I was acquainted with what was going on, none of the attempts were successful. If a boat approached that shore there was no way of reaching the tree in which the nest was built, except by landing on the west bank of the river. To reach it in any other way meant a long and arduous struggle through the drowned land and tangled briar bushes. Therefore, the various shooting parties that tried to exterminate the birds used the river as their nearest way to get at them. As soon, however, as a boat would land, a warning note would be sounded by the mate on watch and the bird in charge of the nest would immediately take wing. Sometimes the male bird was at such a height floating around in the clouds as to be nearly 
imperceptible to the naked eye, but as soon as a boat neared the river bank, the bird would seem to droy like a bolt, uttering piercing cries of warning to its mate.

After several unsuccessful efforts, it was finally decided that three should go in the boat, one should land and the others row the boat back to the lake, hoping thus to deceive the birds. This was done on half a dozen oceasions, the utmost precaution being takeu to prevent either of the birds seeing the third man in his hiding place within reachable distance of the nest, if either of the fish destroyers should return to it, but in every case these efforts were unsuccessful. No matter though the two parties rowed away from the shore, the warning cry of the bird still sounded and neither would return to the tree; but as soon as the third party would re-enter the boat and it left the shore, these birds rould return to the tree, sounding a jubilant note.

An effort was finally made by two boats going together, there being three parties in one boat and two in the other. All five landed on the shore and one of the number, a noted shot on the wing, was left in hiding near the base of the tree in which the nest was. The other four returned to the boats and rowed down the river to the lake. On the way down the birds were plainly seen hanging around and one of them dived and caught a fish of considerable size before the eyes of the watchers. It was then considered certain that they would return to their nest, but, instead, they flew to an adjoining tree and regaled themselves with their catch. After waiting two hours and finding that the old birds were not likely to return to the nest, the boats were rowed back, the watcher was taken on board, and in less than ten minutes after leaving the shore both hawks were back at the nest.

The question of interest is, was the instinct of these birds sufficient to keep track of the number of persons who went into the woods and detect the absence of one on the return? Several efforts were made to illustrate their power of discernment, and in every case where the party 
landed and the same number returned to the boats, one of the birds would immediately return to the nest. I am thoroughly satisfied in my own mind that they knew as well as we ourselves every time an enemy was in ambush waiting their return, but by what process of reasoning they arrived at that conclusion I will not undertake to decide. One thing I do know is, that the fish hawks of the North River were too cunning for the anglers who for two summers sought their destruction and, personally, I was delighted that they escaped the many snares set for them. 


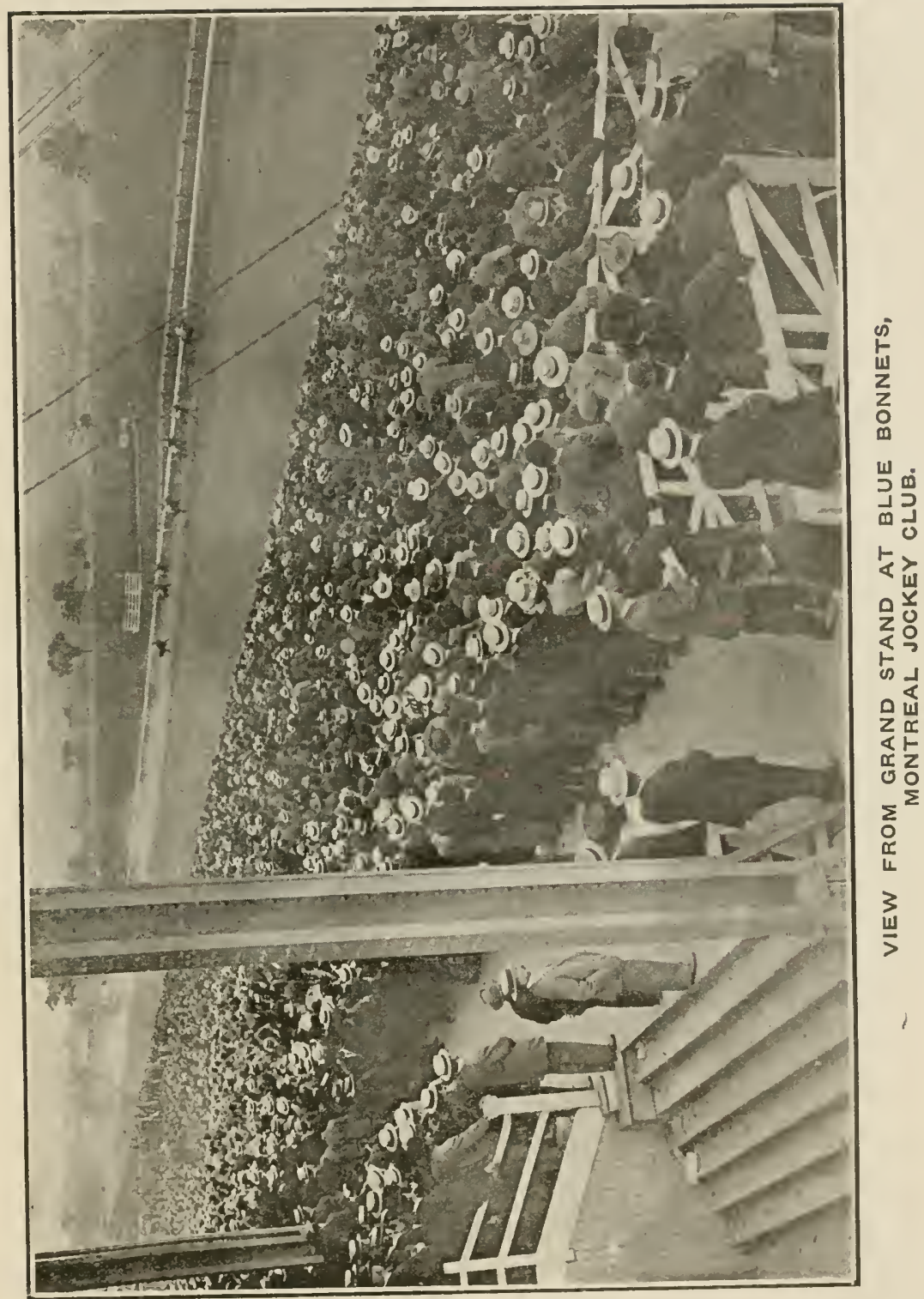





\section{AFTER A RAILWAY BONUS.}

Time has cut a wide swath in the ranks of the spellbinders who thirty years ago represented this city throughout the country.

There was many a hot fight on in those days outside of politics, some of the fiercest being over the securing of bonuses for the construction of railways to this centre.

George Laidlaw was the chief of the bonus hunters, and by his sagacity and foresight did more than any other man in laying the foundation of this present important railway centre.

He was generously aided by many of the best-known citizens of that day. There were W. H. Beatty, John Gordon, Angus Morrison, John Hallam, John Baxter, John Canavan, William Ryan, Alexander Manning, Colonel Arthurs, Hon. John Beverley Robinson, Nathan Dickey, John Ginty, Garrett Frankland, John Taylor, James Scott, John Macdonald, "Square Toes" Medcalf, John Blevins, George Morse and the writer. Verily the seythe-bearer has cut broad and deep amongst those I've mentioned. Out of the score named above all but two, W. H. Beatty and myself, have travelled the through route and ended life's fitful journey. W. H. Beatty is still head of a great legal firm, a wonderfully well preserved man, almost as stalwart and erect in appearance as in those days when he made the farmers of Grey county believe that the construction of the Grey and Bruce line would put them all on Easy street. Last, the writer is still here, and now, as then, wielding the pen and wondering whether the next thirty years will be as prolific of results for the city as the past.

The occurrence I am going to relate took place at Priceville, up in Grey county. We were after a bonus of $\$ 300,000$, and the Hamilton people were fighting like Tro- 
jans against us, seeking to divert the trade to their city instead of Toronto. I had held a meeting twenty miles away in the afternoon and had driven Priceville way to attend one still further south, but finding it had been postponed through a fire in the school house, I decided to drop in and hear what the advocates of the Hamilton railway had to say in its favor. There were two of us, John Canavan being my partner that night. It was not known we were in the village, and a few minutes after the meeting had opened we were able to drop into a back seat in the hall without being observed. The speakers of the evening were two clergymen from Durham. He who was addressing the meeting was quite facetious at the expense of the Toronto scheme and in a quiet neighborly manner was evidently making a good impression on his hearers. He raised a lot of fun by describing our line as follows:

"Those Toronto people who want to build a narrow gauge, but which I call a narrow gouge railway (laughter), are carrying around a portly alderman named John Baxter, who weighs 350 pounds, and they declare that two men of his size can sit comfortably in one seat (roars of laughter). My friends, it is a prodigious fabrication; two men of such size would be almost as big a load as one of their toy engines could haul (loud laughter). My dear brethren, they tell us these narrow gauge roads are a great success in Norway and Sweden. Why don't they tell us of some place nearer home where we could learn something about them? I tell you, my friends, they cannot do it. They cannot tell us of a single country nearer Canada where there ever was one, much less one that is a paying investment."

Recognizing that the parson's talk was having a decided effect on the voters, I jumped to my feet and begged permission from the chairman to ask a question of the reverend gentleman. It was granted me. I began: "Sir, you have told our friends here to-night that the Toronto people cannot mention a single narrow gauge railroad outside of Norway and Sweden. I accept the 
challenge, Sir, and propose right here to settle this question." Looking him straight in the face, I raised my voice and said: "Will you, Sir, as a minister of the Gospel and on your honor as an honest man, deny before this meeting that the Connemara and Bog of Allan narrow gauge railway in Ireland is not a great success to-day and paying over five per cent. dividend to its stockholders? I pause, Sir, for a reply." One glance at the astounded gentleman's face showed me he was thoroughly befogged and he stammered out: "I am very sorry, Mr. Chairman, if I have said anything untrue. I had never heard of the Connemara and Bog of Allan Railroad, therefore, my friends will excuse my mistake." Needless to say, I gave him no chance to proceed further, but immediately complimented him on the honesty of his character in apologizing and admitting he was not acquainted with the subject he was discussing. At this stage my friend Canavan, in the broadest of Irish accents, guaranteed that if the preacher would visit him in his Connemara home he would introduce him to many other pleasant things in addition to the narrow gauge railways. Canavan then sang "The Boys of Connemara" in fine style, every Irishman present joining in the chorus.

We then addressed the electors in favor of the Toronto scheme, carried the meeting with three times three and a tiger, adjourned to the hotel, where a kindly disposed landlord "set 'em up" for the crowd, while we took the leading lights into the dining room and treated them to an oyster supper and - N.B.-The Connemara and Bog of Allan Railway was not constructed owing to some difficulty in floating the bonds, but the vote in Priceville neighborhood three days later was almost unanimous in favor of the Toronto scheme, and thus was the foundation laid for the superb railway system that now serves that northern country. 


\section{A PLOWING MATCH THAT DID NOT COME OFF.}

During twenty years of active platform work I met many able speakers. I used to keep a list of those who opposed me, but it grew to such proportions that I dropped it. During my numerous campaigns advocating a stringent license law against prohibition, it was no unusual thing for half a dozen clergymen in one night to accept my invitation to discuss the question, and fierce though the fight was in many counties of Ontario I am pleased to record the fact that I have only pleasant recollections of my intercourse with my clerical opponents.

In politics I met many hard fighters, but to my mind the most formidable of them all was the late Hon. Archibald McKellar, Minister of Agriculture in the Mowat Government. He was not an orator, but was one of those fluent speakers, full of force and possessing a clear, pleasant voice which made every word sound clear and distinct. In addressing an audience of farmers he was particularly strong, and being himself a practical agriculturist he spoke with authority on farming subjects.

I have alluded to the above facts so that my readers can understand and appreciate that it was no easy task to hold your own in an assemblage of farmers against such an experienced member of their own class.

The circumstance I am about to relate took place at Flesherton, in Grey county, during an election for the Ontario Legislature in which the late A. W. Lauder was the Conservative candidate, and Nathaniel Dickey, the standard-bearer of the Reform party. Mr. McKellar was representing Mr. Dickey on the occasion, and I was acting in a similar capacity for Mr. Lauder. The hall was filled to the doors with farmers, and Mr. McKellar 


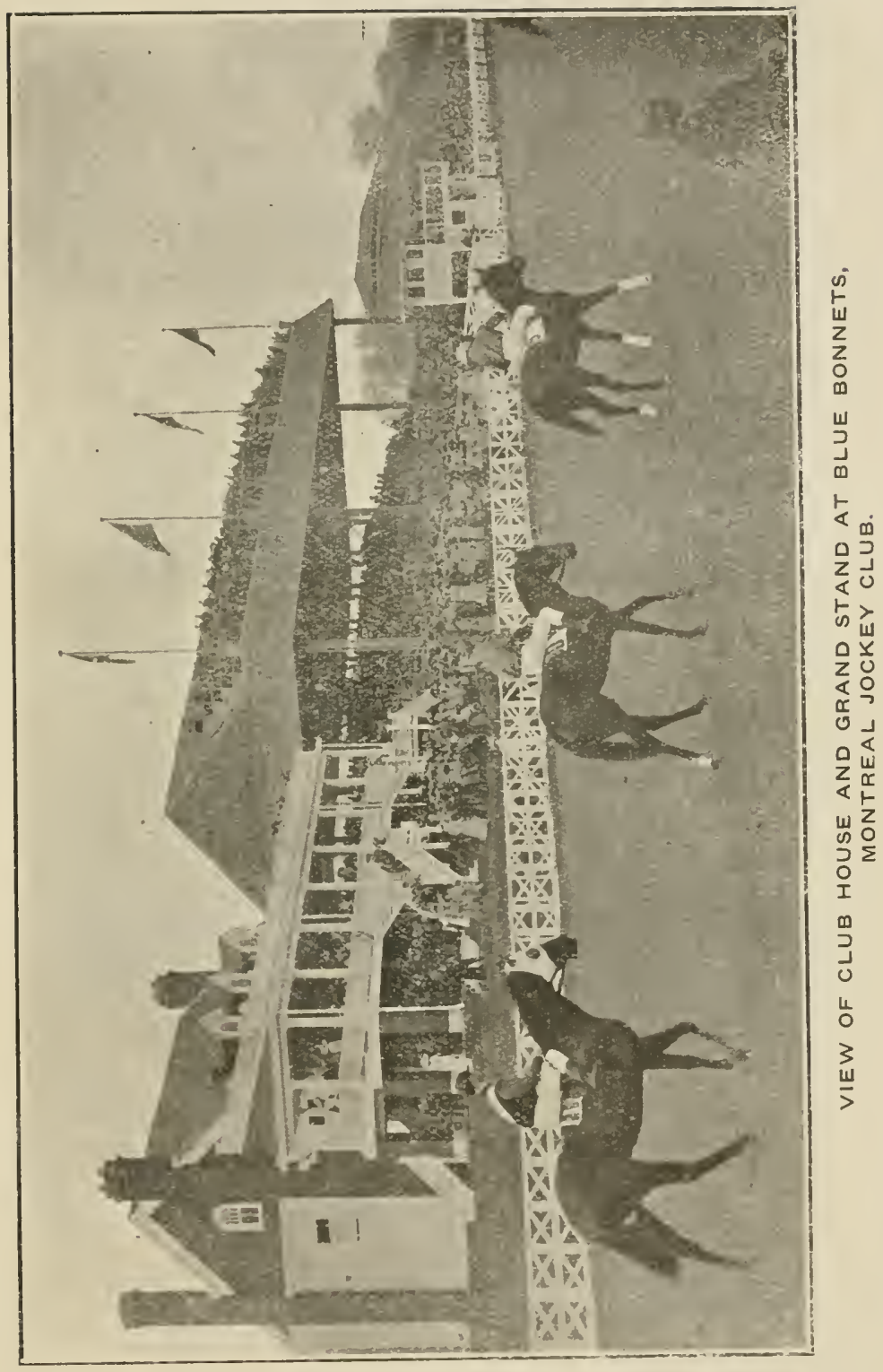



made a strong appeal to them to listen to the voice of one who was proud to declare that he was one of themselves; that there was no branch of farm work, from barn-raising to using the thresher, that he was not familiar with, and he particularly prided himself on his ability to handle a plow in a workmanlike fashion.

It is scarcely necessary to add that this style of speech took immensely with his audience. He very adroitly raised a prejudice against me in the minds of many present by incidentally mentioning that I was a newspaper man brought up in the city, knowing nothing about country life and therefore not competent to tender advice to practical men like Canadian farmers.

Now all this, told in a friendly manner, was, I could easily perceive, making a strong impression on the crowd and this was plainly evidenced by the slimness of the applause which greeted me when I stepped forward to speak on behalf of the Conservative candidate. I had at one or two previous meetings had something of a similar character rubbed into me by Mr. McKellar and I determined there and then to make a bold bluff which I thought might put a stop to future similar attacks.

Addressing myself with considerable energy to the chairman. I asked his special attention while I made a proposition which I thought would meet the approbation especially of the large number of young men who were present in the hall. I said I was weary of hearing Mr. McKellar boast so often of his ability as a plowman and I proposed at this meeting to suggest a practical test which would once and for all settle the matter. I remarked that I had myself some years before the commencement of my city career enjoyed the reputation of being one of the best plowmen in my township. I then suggested that Mr. MeKellar and myself should each hand over $\$ 50$ to the chairman, who should select a field in which we should give a practical illustration of our ability at the plow-handle, and as Mr. McKellar was an older man than myself I accorded him the privilege of being the first to use the team selected for the purpose. 
He was to plow for one hour and I was then to take the same team, plow the same length of time and three competent judges were to decide which man had done the most satisfactory work during the trial; the $\$ 50$ put up by the loser to be divided into three prizes of $\$ 25, \$ 15$ and $\$ 10$ for a plowing match between the young men of the township. The proposal was received with unbounded applause by the crowd, and I called upon Mr. McKellar to either accept or refuse the challenge. He was evidently unprepared for my call, and without taking proper time to consider it he bluntly replied: "I never bet, and I therefore won't accept your offer."

Now, it was not a difficult matter to convince the young men present that there was nothing of a betting character about my proposition, and I expressed deep regret that I should be deprived of the opportunity, which I felt positive would have been mine, of handing over such a handsome amount as the $\$ 50$ of the loser to be competed for by themselves; however, I hoped to be invited by them to their spring plowing match, then I would have a chance of spending a pleasant hour or two and at the same time show them what I could do in the plowing line. At this the applause was of the heartiest description, during which I rushed matters by calling for three cheers for the Queen, and the meeting broke up satisfied that I was a boss plowman and that my opponent was afraid to meet me.

The day after the election, in which the Conservative candidate won, I spent a pleasant hour with the Minister of Agriculture. He expressed surprise at hearing I was a proficient at farm work, and asked me if it was really so that I was such a good plowman. I then admitted the bluff I had played on him by saying that I had never in my life handled a plow but once and that my debut in that line was a dismal failure. I felt, however, that I was justified in playing the card owing to the persistent manner in which he was seeking to raise a prejudice against me as a city chap who knew nothing about country life and ways. He laughed heartily over the joke 
that had been played upon him and many a time afterwards, while he filled the office of Sheriff of Hamilton, I used to drop in upon him and on such occasions he always alluded with a hearty laugh to the plowing episode. In addition to Mr. McKellar's ability on the political platform he was one of those genial men it was ever a pleasure to meet, and his frank off-handed manner made him popular with all classes. 


\section{A CORNER ON RATS.}

On a November night about twelve o'clock I happened to be sitting with several others around one of the big stoves in the office of a well-known hotel in Montreal, when the conversation turned on rats.

It so happened that one of the night porters, whose special duty it was to look after the fires-the hotel being heated in the old-fashioned manner by stoves-was a smart young chap recently from Old London and previous to his leaving the big town he had done quite a little work in the rat-catching line. Now, at the time I speak of the basement portion of the hotel swarmed with rodents. At the approach of winter when there was no longer food for them on the wharves, hosts of them would travel up the sewers and seek in every direction for what was eatable.

The big kitchen of the hotel was a favorite trysting spot of theirs, and the walls were in most places literally honeycombed where they had tunnelled their way through. Cats by the dozen had been introduced for the purpose of killing them off, but after a few weeks of very vigorous exercise pussy would invariably become satiated with the sport and retire from active business and many times in this same place $I$ have seen two or three cats dozing on the bricks in front of the big range and a dozen rats scampering about the room.

On the night I allude to one of the party around the stove was a New York drummer who had a decided antipathy to rats and thought them a little the meanest breed of vermin on the face of the earth, his opinion being largely influenced from his having been once badly frightened by a rat getting into his bed. The talk finally turned to rat catching, and I offered to bet a bottle of "fiz" that I could find a man in the hotel who in thirty 


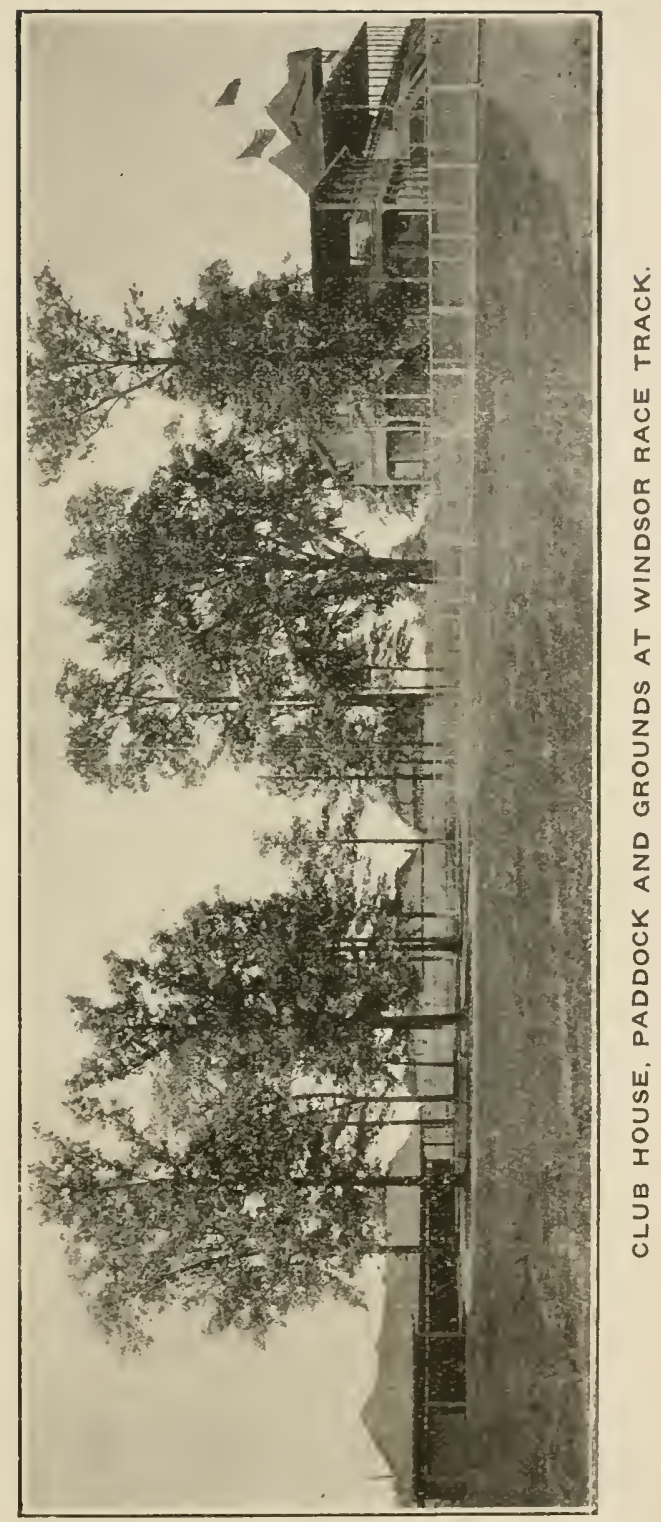



minutes from the time he started would catch half a dozen rats with his hands, unaided by a dog or trap.

The proposition struck the New Yorker as so insanely liberal that he laid the odds of two bottles to one that it couldn't be done. The bet was made. I called up the porter and asked if he would tackle the job. "Dave" asked no better fun than catching rats, knowing from experience that he was always well rewarded for his proficiency in that line. At his request the five of us followed him into the carving room and kitchen to see for ourselves just what preparations he desired to make. What he did when there was to open the slide doors under the meat table, also the door between the two rooms, then provide himself with a big broom.

Returning to the office the New Yorker took the time and all hands waited eagerly for Dave to give the word when the first raid should be made. He kept us nearly ten minutes before giving the signal, when, as quietly as possible he stepped to the door and as he rushed into the carving room all hands followed. The rat catcher's first trick was to shut the sliding doors under the carving tables and the door between the two rooms, and when the gas was turned up there was such a scampering of rats across the floor that our Yankee friend jumped on the table velling at his highest pitch.

Dave proceeded to work in the most methodical manner. He would single out a rat, and with broom in his left hand, chase him into a corner. He would then clap the broom over him and hold him down, then with his right hand catch hold of the rat's tail, swiftly draw him from under the broom, then keep swinging him round and round until he walked to a big wire cage over on one of the tables, when he would pop him in.

In ten minutes' time he caught seven rats, and therefore easily won my bet, but to give the Gothamite a little fun for his money, Dave made two other raids, securing five the second trip and four the third time. Then to show his utter fearlessness in handling rats, he allowed the New Yorker to point out the ugliest and wickedest- 
looking rodent in the cage, after which he put in his hand, not gloved nor in any way protected, brought him out and opened the front of his onter flannel shirt and let him loose in his breast. The last act was all our American friend wanted to see, and the appearance of his face as Dave unbuttoned his shirt and popped the rat in was a mixture of fright and disgust it would be impossible to describe.

A pleasant hour was spent over the wine, and arrangements were made to get some terriers in the morning and polish off the rats. This was duly attended to, and the New Yorker left Montreal satisfied that from personal experience he could tell a rat story that would bear comparison with anything in that line over the border. 


\section{THORNCLTFFE STOCK FARM.}

One thousand acres of upland, meadows and forestcrowned hills for a background, go to make up a noble estate, and when this is located on the outskirts of a city of three hundred thousand population, its natural beatuty is rendered still more attractive by its close proximity to a great eommercial centre like Toronto. The Thorncliffe Stock Farm is well known all over Cauada. It has been the home, not alone of many noted thoroughbreds, but also of prize-winning Clydesdales, which have gained high honors in Canadian and American show rings; Jersey cattle, Shropshire sheep and Yorkshire pigs. At one time flocks of sheep roamed o'er the pastures of Thorncliffe-animals so choicely bred that buyers rere attracted from all parts of the continent, but the damage caused by hungry, roaming dogs, was so great and so difficult to guard against that the owner was reluctantly compelled to relinquish one of his favorite enterprises. When individual members of a flock of sheep are worth all the way from $\$ 100$ to $\$ 600$ the damage caused by sheep-killing dogs can easily foot up to a large amount, and though men were employed to guard these flocks by day and carefully house them at night, yet it was found impossible to secure their safety and their breeding was discontinued.

The premier thoroughbred sire at Thorncliffe is the imported English horse Orme Shore, by the worldfamous Orme (sire of Flying Fox, which sold for $\$ 187$,000 , the highest price ever paid for a horse). Virginia Shore, the dam of Orme Shore, is by John Davis, by Voltigeur, out of Distant Shore by Hermit. Orme is by Ormonde, ont of Angelica, by Galopin.

Judging by the success of the get of Orme Shore at the last spring meeting of the Ontario . Jockey Club, it is but 
reasonable to assume that in addition to his own high quality as a performer, he will prove a brilliant success at the stud. As a two-year-old he won five races, carrying from 124 to 135 pounds. He is a horse of superb style and faultless conformation, and in the opinion of Major Daingerfield, of Lexington, he is one of the grandest thoroughbreds he ever looked upon.

The herd of Jersey cattle on the farm, though not a large one, represents the choicest prize-winning blood of this popular breed of cattle; while the Lord Rosebery strain of Yorkshire pigs are said to be the choicest specimens in this country. Buyers from Tennessee, Ohio, Illinois and many other States, have enriched their home stock with this popular strain. In fact, the demand, both at home and abroad, taxes the capacity of the farm to supply.

Mr. Robert Davies, the owner of this splendid estate, is a central figure in the business life of Toronto. He is owner of one of the greatest brick manufacturing plants in the world, also proprietor of a large paper mill and the owner of two other extensive manufacturing concerns in the city. One would naturally suppose that every moment of his time was occupied and his mind engrossed with business cares and anxieties. Such guessing, however, would be wide of the mark. Wherever you meet him, he impresses you as a man who has nothing to worry him. A smiling face and a cheery voice are two of his chief characteristics and he never shows to better advantage than when, as Squire of Thorncliffe, he welcomes his guests, either at the old farm-house in the valley or at his splendid mansion at Todmorden. Many a noted gathering at both places could be recorded every year. Turfmen and horsemen from all over the continent have visited Thorncliffe, and one and all carry away with them pleasant recollections of the beantiful estate and its popular owner. 



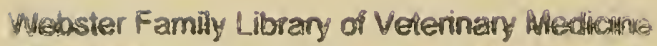
Curatrangs School of Veterinary Medicine at

Tuffs University 200 Westboro Road

North Grafton, MA 01536 



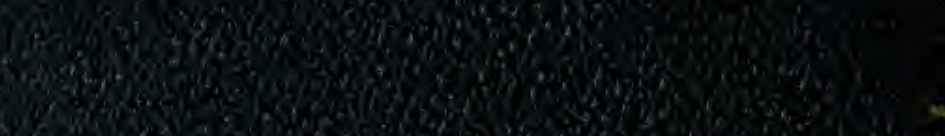

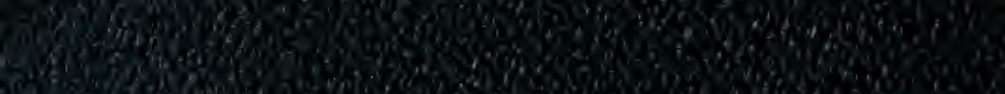
20.5. 20.

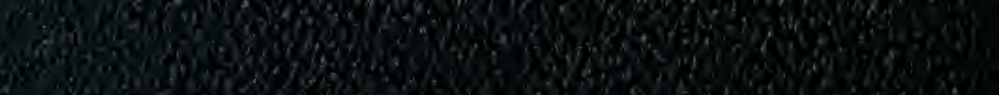
27.

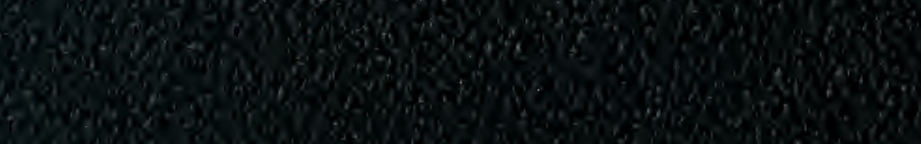

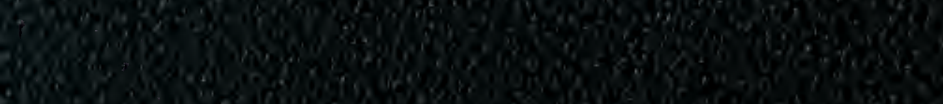

4.5.

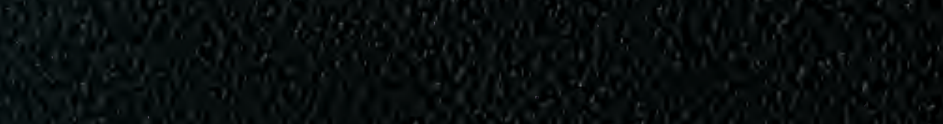

$18 x^{3}$

10 